\title{
Molecular stress responses to mineral dusts : rodent lungs and pulmonary target cells as models to study the toxicity of asbestos fibers and related mineral dusts
}

Citation for published version (APA):

Janssen, Y. M. W. (1993). Molecular stress responses to mineral dusts : rodent lungs and pulmonary target cells as models to study the toxicity of asbestos fibers and related mineral dusts. [Doctoral Thesis, Maastricht University]. Datawyse / Universitaire Pers Maastricht. https://doi.org/10.26481/dis.19931007yj

Document status and date:

Published: 01/01/1993

DOI:

10.26481/dis.19931007yj

Document Version:

Publisher's PDF, also known as Version of record

Please check the document version of this publication:

- A submitted manuscript is the version of the article upon submission and before peer-review. There can be important differences between the submitted version and the official published version of record. People interested in the research are advised to contact the author for the final version of the publication, or visit the DOI to the publisher's website.

- The final author version and the galley proof are versions of the publication after peer review.

- The final published version features the final layout of the paper including the volume, issue and page numbers.

Link to publication

\footnotetext{
General rights rights.

- You may freely distribute the URL identifying the publication in the public portal. please follow below link for the End User Agreement:

www.umlib.nl/taverne-license

Take down policy

If you believe that this document breaches copyright please contact us at:

repository@maastrichtuniversity.nl

providing details and we will investigate your claim.
}

Copyright and moral rights for the publications made accessible in the public portal are retained by the authors and/or other copyright owners and it is a condition of accessing publications that users recognise and abide by the legal requirements associated with these

- Users may download and print one copy of any publication from the public portal for the purpose of private study or research.

- You may not further distribute the material or use it for any profit-making activity or commercial gain

If the publication is distributed under the terms of Article 25fa of the Dutch Copyright Act, indicated by the "Taverne" license above,

Download date: 26 Apr. 2023 


\section{MOLECULAR STRESS RESPONSES TO MINERAL DUSTS}

Rodent lungs and pulmonary target cells as models to study the toxicity of asbestos fibers and related mineral dusts 
Produktie en layout: Datawyse I Universitaire Pers Maastricht ISBN $905278096 \mathrm{x}$ 


\section{MOLECULAR STRESS RESPONSES TO MINERAL DUSTS}

\section{Rodent lungs and pulmonary target cells as models to study the toxicity of asbestos fibers and related mineral dusts}

\section{PROEFSCHRIFT}

ter verkrijging van de graad van doctor aan de

Rijksuniversiteit Limburg te Maastricht, op gezag van de Pro-Rector, Prof. dr. L. Boon, volgens het besluit van het College van Dekanen, in het openbaar te verdedigen op donderdag 7 oktober 1993 om 16.00 uur

$$
\text { door }
$$

Yvonne Maria Wilhelmina Janssen

geboren te Elsloo op 24 mei 1966

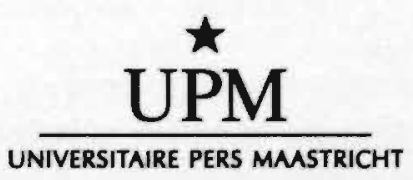




\section{Promotores:}

Prof. dr. P.Th. Henderson (MBL-TNO, Rijswijk)

Prof. B.T. Mossman (University of Vermont, Burlington, U.S.A.)

Co-promotor:

Dr. P.J.A. Borm

\section{Beoordelingscommissie:}

Prof. dr. H.A.J. Struijker Boudier (voorzitter)

Prof. dr. A. Bast (Vrije Universiteit Amsterdam)

Prof. dr. ir. P.H.M. Lohman (Rijksuniversiteit Leiden)

Prof. dr. F. Ramaekers

Prof. dr. E.F.M. Wouters 
"I will study and get ready and the opportunity will come" Abraham Lincoln

Voor mijn ouders 


\section{CONTENTS}

CHAPTER 1 General introduction. p. 9

CHAPTER 2 Cell and tissue responses to oxidative damage.

Laboratory Investigation, In press. p. 15

CHAPTER 3 The role of active oxygen species in the lung toxicity induced by mineral fibers and particulates. Oxidants in the Environment. J.O. Nriagu,ed. John Wiley \& Sons, NY, (In Press, 1993). p. 45

CHAPTER 4 Expression of antioxidant enzymes in rat lungs after inhalation of asbestos or silica. Journal of Biological Chemistry, Vol 267, pp.10625-30, $1992 . \quad$ p. 61

CHAPTER 5 Increased expression of manganese-containing superoxide dismutase in rat lungs after inhalation of inflammatory and fibrogenic minerals. Free Radicals in Biology and Medicine, In press. $\quad$ p. 79

CHAPTER 6 Oxidant stress responses in human pleural mesothelial cells exposed to asbestos or xanthine/xanthine oxidase. American Review of Respiratory Diseases, submitted. p. 95

CHAPTER 7 Persistent induction of c-fos and c-jun protooncogene expression by asbestos. Proceedings of the $\mathrm{Na}$ tional Academy of Science of the U.S.A., Vol 90 , pp.3299-3303, $1993 \quad$ p. 113

CHAPTER 8 c-fos and c-jun protooncogene expression in rodent pleural mesothelial cells and tracheal epithelial cells after exposure to asbestiform fibers and particulates. Cancer Research, submitted. p. 128 
CHAPTER 9 Summary and general discussion p. 147 SAMENVATTING p. 152

PUBLIKATIES p. 155

CURRICULUM VITAE p. 158

DANKWOORD / ACKNOWLEDGEMENTS p. 159 


\section{General Introduction}

Exploitation of mineral dusts has been described in ancient cultures. For example, asbestos minerals were used in burial rituals to ascertain proper cremation. The word asbestos is derived from the Greek $\alpha$ - $\sigma \beta \varepsilon \sigma \tau \zeta \zeta$ which literally means not-quenchable. Currently, the term asbestos refers to 6 naturally occurring mineral silicate fibers which are subdivided in 2 categories, as shown in figure 1 (1). Chrysotile, the only member of the serpentine family accounts for over $90 \%$ of the world production of asbestos and has been mined extensively in Canada and Russia (2). The amphibole family of asbestos fibers has 5 members. Crocidolite and amosite, blue and brown asbestos, respectively, are now only mined in South Africa. Tremolite, actinolite and anthophyllite have only rarely been mined for use as commercial asbestos. However these amphibole minerals are sometimes found as contaminants of other exploited minerals such as talc, chrysotile and vermiculite among other minerals (1). Asbestos minerals due to their great tensile strength, resistance to heat and chemicals, and low cost in comparison to man made materials have been used extensively in a number of industries. For instance, asbestos is found in brake linings, floortiles, insulation materials, cement, and in many domestic applications. Asbestos

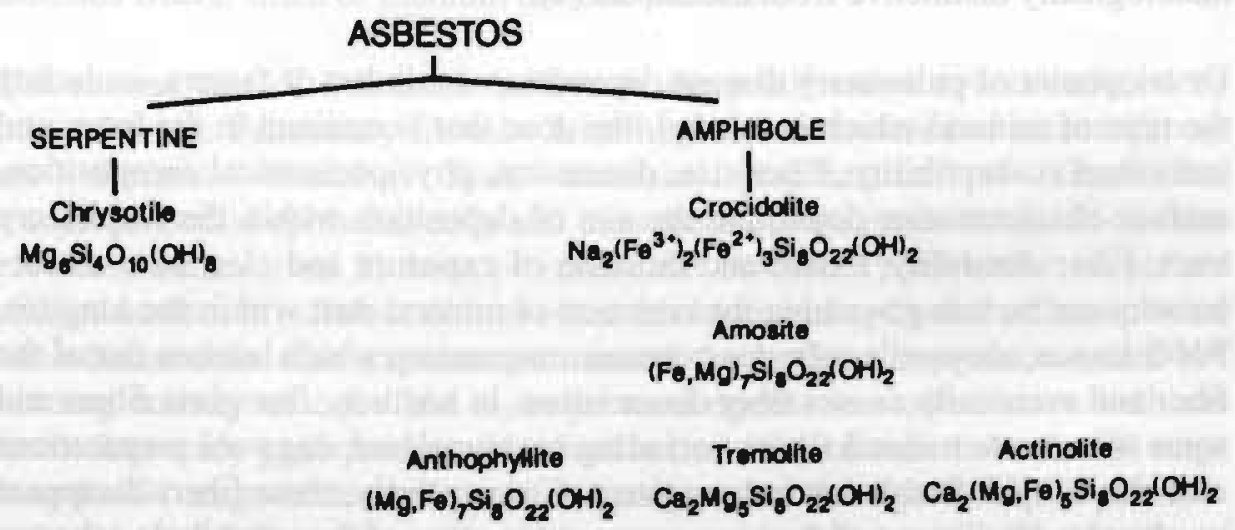

Figure 1. Classification of ashestos fibers. Chrysotile is the only member of the serpentine family and accounts for $90 \%$ of the world's production of asbestos. The amphiboles are presented in order of their relative industrial importance. 
fibers differ greatly in their chemical composition, size and shape. Although amphibole asbestos fibers have not been mined as extensively as chrysotile, in the light of past workplace exposures and their toxicity, it remains important to study mechanisms implicated in the development of pulmonary disease following exposure to these minerals (2). As described in a recent report by Mossman and coworkers, asbestos engenders both fear and panic in U.S. society. This has lead to an explosion of asbestos identification and removal companies, a ban of asbestos usage in specific applications, and usage and development of naturally occurring and synthetic fibers as asbestos substitutes (2). Among non-asbestos naturally occurring mineral fibers are erionite, a zeolite mineral, attapulgite, wollastonite, and sepiolite (1). Man-made mineral fibers (MMMF) is a generic term applied to fibrous inorganic substances made primarily from rock, clay, slag, or glass. Such fibers are classified in three general groups; glassfibers, rockwool, and slagwool and ceramic fibers (3). A number of mineral particles, including crystalline silica dusts, titanium dioxides, and coal mine dusts, mined for different purposes, also should be considered in toxicological studies because of their varying toxic potentials (4).

Exposure to mineral dusts in the occupational environment can give rise to a spectrum of pulmonary disorders. For example, asbestos inhalation can lead to the development of pulmonary fibrosis (asbestosis), a non-malignant disorder, as well as the malignant diseases bronchogenic carcinoma and mesothelioma (2). Development of malignant disease is not limited to asbestos fibers. For instance, in several villages in central Turkey, high incidences of mesothelioma were reported due to the presence of erionite, a natural contaminant of the soil (5). Inhalation of silica dusts primarily causes pulmonary fibrosis (silicosis), histologically distinctive from asbestosis (4).

Development of pulmonary disease depends on a number of factors, including the type of mineral which is inhaled, the dose that is retained in the lung, and individual susceptibility. Fiber size, dimension, physicochemical composition, surface characteristics determine the site of deposition within the respiratory tract. Fiber durability, extent and duration of exposure and clearance characteristics are factors governing the retention of mineral dust within the lung (6). For instance, chrysotile asbestos contains magnesium which leaches out of the fiber and eventually causes fiber dissociation. In addition, fine glass fibers and some man made mineral fibers, including rockwool and slagwool preparations also show rapid dissolution in lung tissue. Consequently, these fibers disappear much more readily out of the lung compared to some of the amphibole asbestos fibers, many of wich are retained within the lung for multiple years (6). This can contribute to the differences in toxic potentials of these mineral dusts. 
The mechanisms involved in the development of lung disease after inhalation of mineral dusts are not well understood. A number of processes triggered within the lung following deposition of mineral dusts appear to be important in toxicity of minerals. These include activation of macrophages and other phagocytic cells (7), release of cytokines and growth factors (8), induction of inflammation and the production of active oxygen species (AOS) (9).

In the last decade, a lot of evidence accumulated pointing to active oxygen species (AOS) as mediators of mineral dust-induced lung disease. A number of mineral fibers have the intrinsic capacity to generate AOS in the absence of cells (10). Alternatively, AOS can also be generated following deposition of mineral dusts in the lung as a consequence of activation of enzymatic pathways in a number of different cell types including macrophages and polymorphonuclear leukocytes (11). Elaborate defense systems against active oxygen species exist in mammalian and bacterial cells. These antioxidant systems consist of both enzymatic and non-enzymatic components. Lung disease can ensue in conditions of excessive production of active oxygen species or deficient functioning of the antioxidant system (12).

The aim of the first part of this thesis is to study whether rat lungs, after exposure by inhalation, or isolated target cells of mineral dust-induced disease (mesothelial cells, fibroblasts) respond to mineral dust-induced oxidative stress with alterations in antioxidant defenses. Other goals are to determine whether alterations in antioxidant defenses can be related to disease formation or progression, or alternatively whether these alterations can serve as biomarkers of oxidative stress. Different mineral dusts are used in these studies, including asbestos fibers, silica or titanium dioxide particles.

The second part of this thesis addresses the proliferative events induced by mineral dusts. Pulmonary fibrosis, bronchogenic carcinoma and mesothelioma are diseases resulting from aberrant proliferation of fibroblasts, tracheobronchial epithelial cells and mesothelial cells, respectively. Molecular mechanisms involved in these processes are obscure. Proliferative events are studied in vitro in isolated cultures of tracheobronchial epithelial cells or pleural mesothelial cells after exposure to mineral dusts. Gene expression and DNA binding activity of c-fos and c-jun protooncogenes is studied since both are immediate early gene products involved in transition of cells from the $\mathrm{G} 0$ stage into the G1 stage of the cell cycle and progression through G1. Both protooncogenes are implicated in cell proliferation and transformation. The family of fos and jun genes is able to dimerize and form the transcription factor AP-1, a regulatory factor that transfers a signal generated on the plasma membrane into the nucleus. Thus, AP-1 serves as a signal transducer and affects expression of 


\section{Cellular Responses to Mineral Dusts}

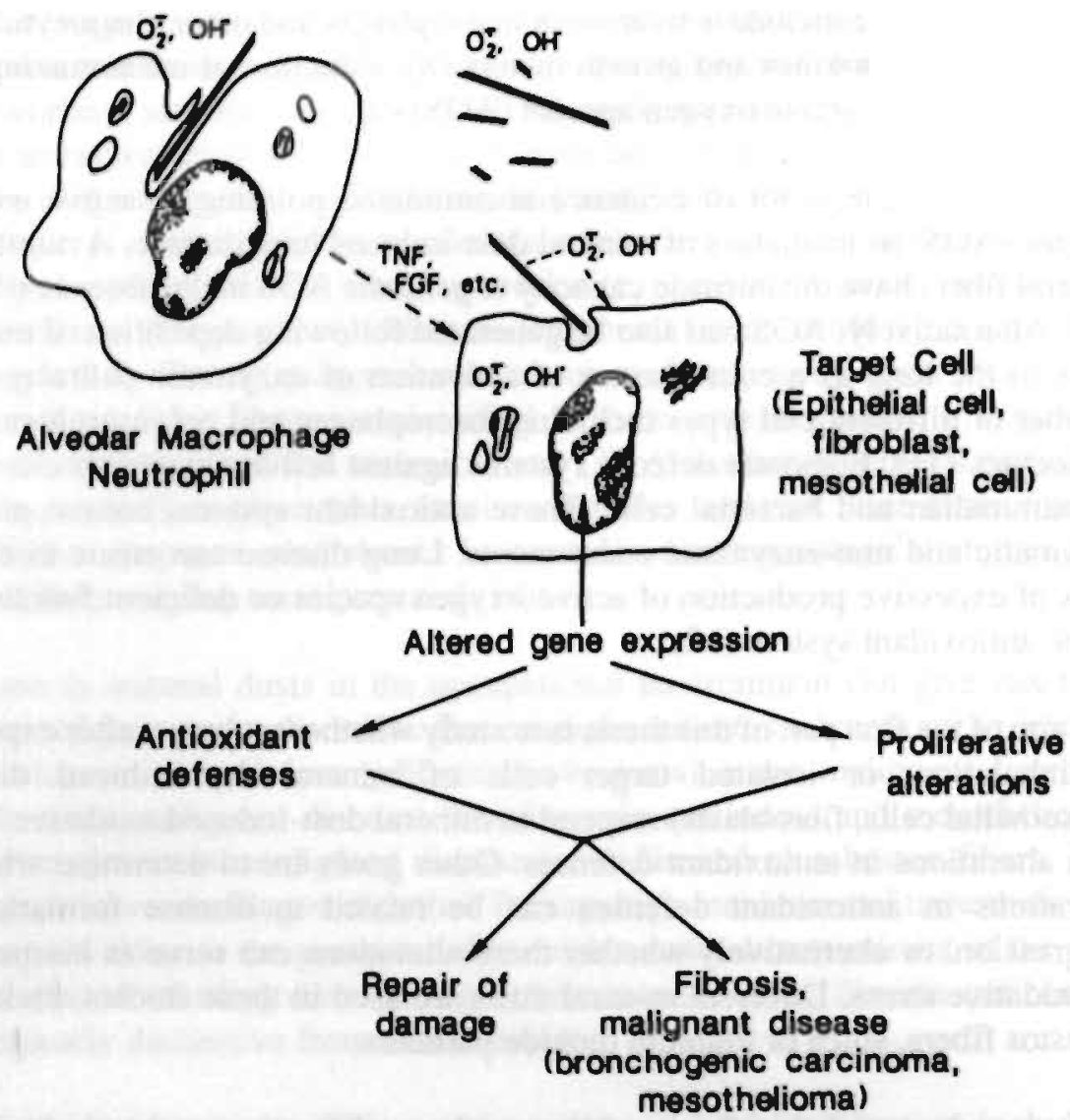

Figure 2. Responses activated in cells after exposure to mineral dusts. Mineral dusts are phagocytized by alveolar macrophages and neutrophils. This causes formation of AOS and release of cytokines and growth factors which affect different target cells of the lung. In addition, mineral dusts can interact directly with the target cells. Formation of AOS generated intrinsically by mineral fibers or following activation of enzymatic pathways within the cell can lead to alterations in gene expression. For example, genes encoding antioxidants or alternatively, genes involved in cell proliferation are induced. The overall balance of these processes determines whether acute cellular effects caused by mineral dusts will be repaired, or alternatively lead to disease. 
genes involved in differentiation and proliferation (13). In addition, gene expression of ornithine decarboxylase (ODC), which increases during $\mathrm{Gl}$ and $\mathrm{S}$ phases of the cell cycle and is essential for cell division is measured (14). These experiments aid in clarifying the molecular events triggered within the cell following mineral dust exposure and their relationship to proliferation. Severall approaches are used to determine whether AOS are involved in mineral dust-induced proliferation, including preventive approaches using antioxidants and altematively generating systems of AOS. Native and modified asbestiform fibers are used since these fibers give rise to bronchogenic carcinoma or mesothelioma. These studies are designed to delineate the properties of asbestos fibers that are important in causing proliferation in these target cells of pulmonary disease. In addition, different fibrous dusts, including man made vitreous fibers and refractory ceramic fibers are tested to determine if they have comparable potencies in causing proliferation in these target cells.

Chapters 2 and 3 are general reviews concerning AOS. In chapter 2, general responses of cells to active oxygen species or compounds giving rise to $\mathrm{AOS}$ are discussed. A section on mineral dusts is included in order to compare cellular responses to mineral dusts with those elicited by other oxidant stresses. This provides an overview of oxidant stress responses and strengthens the role of AOS in mineral dust-induced disease. In chapter 3 the role of AOS in mineral dust induced toxicity is addressed in more detail. Chapters 2 and 3 furthermore stress the findings of proliferative alterations following exposure to mineral dusts or other oxidant stresses, concurrent with alterations in antioxidant defenses. This provides the framework of this thesis, as outlined in figure 2. Chapters 4-6 are detailed studies of the regulation of antioxidant defenses in rat lung or target cells after exposure to mineral dusts. Chapters 7 and 8 address proliferative responses of rodent mesothelial cells and epithelial cells to asbestiform minerals and implications for disease. Lastly, in Chapter 9 the findings are summarized and their importance in toxicological studies described. 


\section{REFERENCES}

1 Liddell D. Exposure to mineral fibers and human health: Historical background. In: Liddell D, Miller K (Eds.) Mineral Fibers and Health. CRC Press" Boca Raton 1991, pp 1-9.

2 Mossman BT, Bignon J, Corn M, Reaton A, Gee JBL. Asbestos: Scientific developments and implications for public policy. Science 1990; 247:294-301.

3 Asbestos in Public and Commercial Buildings: A Literature Review and Synthesis of Current Knowledge. Health Effects Institute - Asbestos Research. Cambridge, 1991.

4 Becklake MR. The mineral dust diseases. Tubercle Lung Dis. 1992; 73:13-20.

5 Artvinli M, Baris YI. Malignant mesothelioma in a small village in the Anatolian region in Turkey: an epidemiological study. J Natl Cancer Inst. 1979; 63:17-22.

6 Davis JMG. Information obtained from fiber-induced lesions in animals. In: Liddell D. Miller K (Eds.) Mineral Fibers and Health. CRC Press, Boca Raton, 1991, pp.249-263.

7 Rom WN, Travis WD, Brody AR. Cellular and molecular basis of asbestos-related disease. Am Rev Respir Dis 1991; 143:408-422.

8 Driscoll KE, Maurer JK. Cytokine and growth factor release by alveolar macrophages: Potential biomarkers of pulmonary toxicity. Toxicol Pathol 1991; 19:398-405.

9 Mossman BT, Marsh JP. Role of active oxygen species in asbestos-induced cytotoxicity, cell proliferation and carcinogenesis. In: Harris CC, Lechner JF, Brinkley BR (Eds.) Cellular and Molecular Aspects of Fiber Carcinogenesis. Cold Spring Harbor, 1991, pp 159-168.

10 Zalma R, Bonneau 1, Jaurand MC, Guignard J, Pezerat H. Formation of oxy-radicals by oxygen reduction arising from the surface activity of asbestos. Can J Chem 1988; 65:2338-2343.

11 Sibille Y, Reynolds HY. Macrophages and polymorphonuclear neutrophils in lung defence and injury. Am Rev Respir Dis 1990; 141:471-501.

12 Heffner JE, Repine JE. Pulmonary strategies of antioxidant defense. Am Rev Respir Dis 1989: 140:531-554.

13 Angel P, Karin M. The role of Jun, Fos and the AP-1 complex in cell-proliferation and transformation. Biochim Biophys Acta 1991; 1072:129-157.

14 Pegg AE, McCann PP. Polyamine metabolism and function. Am J Physiol 1982; 243:212-221. 


\section{Cell and Tissue Responses to Oxidative Damage}

Yvonne M W Janssen*, Bennett Van Houten*, Paul J A Borm", and Brooke T Mossman*.

*Department of Pathology, University of Vermont, Medical Alumni Building, Burlington VT 05405 U.S.A.

${ }^{+}$Department of Health Risk Analysis and Toxicology, University of Limburg, Maastricht, The Netherlands. 


\section{Introduction}

Although oxygen is a necessary requirement for aerobic organisms, its more reactive metabolites, active oxygen species (AOS), are implicated in a number of diseases. Bacterial and mammalian cells have elaborate defense mechanisms against AOS including enzymatic and non-enzymatic antioxidants (1-3). However, under certain conditions, these defense systems may be inadequate, and cell damage and/or disease ensue.

Currently, much attention is focused on AOS and their deleterious effects on cells (lipid peroxidation, DNA damage etc.). Moreover, biomarkers for prediction of disease are being developed to measure the status of oxidative stress in individuals (4-10). However, little is known about cellular responses to AOSmediated damage. For example, some cells may respond to AOS-mediated stress by altering expression of certain genes and synthesizing proteins involved in scavenging or repair of AOS-induced lesions. These phenomena may reflect adaptive responses. Other cell types may be deficient in repair of damage induced by oxidant stress. In this review, pathways of generation of AOS and various diseases associated with elaboration of AOS and/or altered DNA repair will be addressed briefly. Lastly, we will focus on specific responses of mammalian cells to oxidative stress and their implication in cellular defense, adaptation and protection from disease.

\section{Formation and Removal of Active Oxygen Species (AOS)}

During reduction of molecular oxygen to water in cellular respiration, partially reduced oxygen species are produced which are very reactive with protein, lipids and DNA (3). These AOS are formed in the mitochondrial electron transport chain (11), the cyclooxygenase pathway, and by cellular enzymes such as cytochrome P450 oxidase, xanthine oxidase and NADPH oxidase $(3,7,11,12)$. AOS have important physiological roles in the metabolism of various xenobiotic compounds (7) and in bacterial killing by phagocytes. During phagocytosis, a membrane bound enzyme (NADPH oxidase) is activated in neutrophils and macrophages which evokes an oxidative burst and the formation of various AOS (Figure 1). Neutrophils contain myeloperoxidase which converts hydrogen peroxide $\left(\mathrm{H}_{2} \mathrm{O}_{2}\right)$ into hypochlorous acid $(\mathrm{HOCl})$, a relatively long-lived oxidant $(7,10)$. In cellular and acellular systems, the presence of iron or other divalent cations can convert superoxide $\left(\mathrm{O}_{2}^{-}\right)$and hydrogen peroxide $\left(\mathrm{H}_{2} \mathrm{O}_{2}\right)$ to the hydroxyl radical $(\mathrm{OH})$, one of the most reactive AOS (13). Another potential source of $\mathrm{O}_{2}^{-}$is the peroxisomal enzyme, xanthine oxidase (14), which generates $\overline{\mathrm{O}_{2}}$ and $\mathrm{H}_{2} \mathrm{O}_{2}$ during the metabolism of xanthine or hypoxanthine to uric acid $(7,15)$. Cellular conversion of xanthine dehydrogenase to xanthine oxidase 


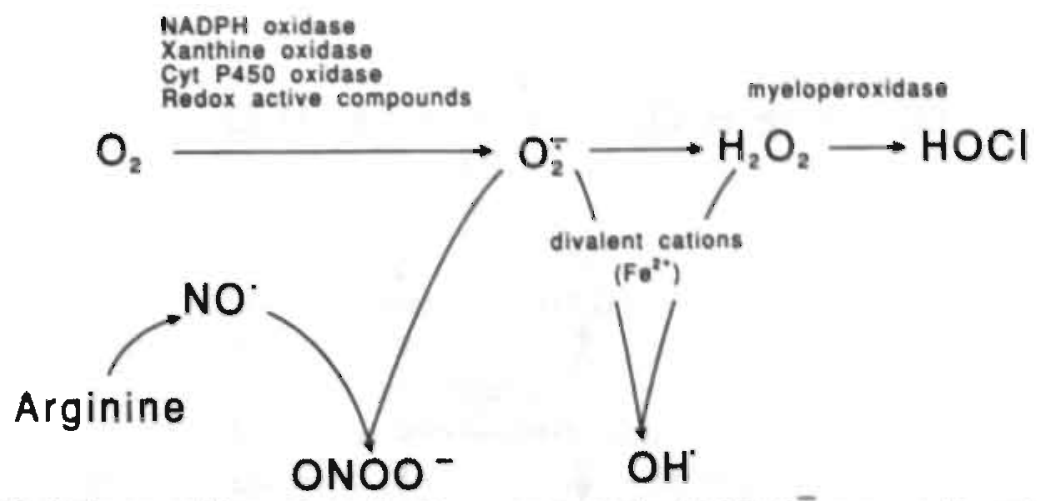

Figure 1. Pathways of formation of active oxygen species (AOS). $\overline{\mathrm{O}_{2}}$, superoxide anion; $\mathrm{OH}$, hydroxyl radical; $\mathrm{H}_{2} \mathrm{O}_{2}$, hydrogen peroxide; $\mathrm{NO}$, nitric oxide; $\mathrm{HOCl}$, hypochlorous acid; $O N O O$-, peroxynitrite anion.

occurs in a variety of cell types after exposure to specific stimuli, including phorbol esters, Tumor Necrosis Factor $\alpha$ (TNF) or ischemia-reperfusion injury $(15,16)$. Nitric oxide (NO), formed during oxidation of arginine, can react with $\mathrm{O}_{2}$ to form peroxynitrite (ONOO-), a stable intermediate which decomposes into a strong oxidant with reactivity similar to $\mathrm{OH} \cdot(17)$.

A variety of exogenous chemical and physical agents also cause production of AOS $(3,13,18-21)$. These include mineral dusts, ozone, nitrogen oxides and other gases, ultraviolet radiation, ionizing radiation, etc. Other compounds constituting an important source of oxidant stress are phytoalexins or plant stress metabolites such as rose bengal, psoralen and quinones (22). Some of these species can undergo redox cycling within the cell resulting in a continuous generation of AOS (22).

AOS are potentially harmful to cells because they interact with and modify a spectrum of biomolecules $(7,12,18,23)$. Some biochemical effects of AOS resulting in progressive cell damage include lipid peroxidation, oxidative modification of proteins, and DNA alterations. Lipid peroxidation consists of a series of reactions resulting from the interaction of AOS with polyunsaturated fatty acids. In a chain reaction, a range of AOS can be formed including $\mathrm{OH}$, $\mathrm{H}_{2} \mathrm{O}_{2}$, singlet oxygen, peroxyl and alkoxyl radicals (10). Numerous studies use products of lipid peroxidation as indicators of oxidative stress, and sensitive techniques are available to measure the extent of lipid peroxidation in cells, lavage fluids and urine $(6,24)$.

AOS also activate or inactivate proteins. For example, stimulated neutrophils which release AOS can inactivate glutamate synthetase and several other endogenous enzymes (25) including copper zinc-containing superoxide dismutase (CuZnSOD) (26). Altematively, guanylate cyclase is activated following sulfhydryl oxidation by $\mathrm{H}_{2} \mathrm{O}_{2}$ resulting in the production of the second mes- 


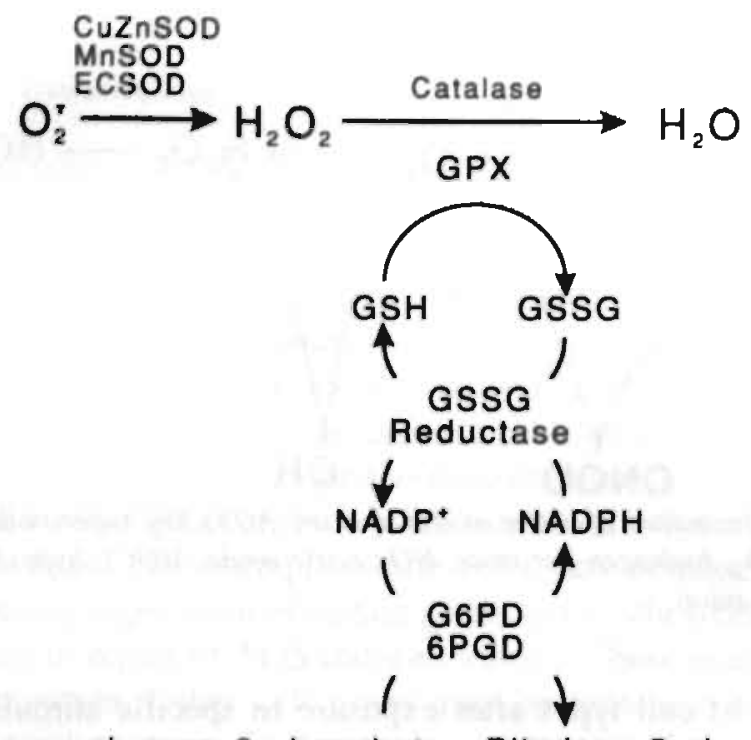

glucose-6-phosphate Ribulose-5-phosphate

Figure 2. Detoxification of AOS by antioxidant enzymes. This interrelated system is complemented by a number of non-enzymatic antioxidants. CuZnSOD, copper zinc-containing superoxide dismutase; $M n S O D$, manganese-containing superoxide dismutase; ECSOD, extracellular superoxide dismutase; GPX, glutathione peroxidase; GSH, reduced glutathione; GSSG, oxidized glutathione; G6PD, glucose 6-phosphate dehydrogenase; $6 P G D$. 6-phosphogluconate dehydrogenase.

senger, cyclic GMP (27). Various AOS also inactivate certain antioxidant enzymes or generating systems directly (26,28-31). For example, inactivation of xanthine oxidase by $\mathrm{H}_{2} \mathrm{O}_{2}$ might provide a negative feedback mechanism for prevention of cellular or tissue injury (32).

Elaborate defense systems against AOS exist in bacterial and mammalian cells $(1,3,19,33,34)$. The functions of some relevant antioxidant enzymes are outlined in Figure 2. Mammalian tissues contain three forms of superoxide dismutase (SOD), an enzyme converting $\overline{\mathrm{O}}_{2}^{-}$to $\mathrm{H}_{2} \mathrm{O}_{2}$. These include two CuZnSODs, one localized extracellularly (ECSOD)(35) and the other within peroxisomes (36) and the cytoplasm (37). The third form of SOD contains manganese (MnSOD) and is localized almost exclusively in the mitochondria (38). The SODs and other antioxidant enzymes, including catalase and glutathione peroxidase (GPX), are complemented by a number of non-enzymatic factors located both intra- and extracellularly $(34,39)$. Sulfhydryl-containing molecules such as glutathione (GSH), vitamins $\mathrm{C}$ and $\mathrm{E}$, albumin, 
ceruloplasmin, bilirubin and uric acid are components of the non-enzymatic antioxidant system (12). Metallothionein and heme oxygenase are proteins induced after exposure to agents that cause oxidative stress $(40,41)$. Although not considered traditionally as antioxidants, both proteins have antioxidant functions. Metallothionein, a sulfhydryl-rich protein involved in metal homeostasis, is a scavenger of $\mathrm{OH}$ in vitro (40). Heme oxygenase, an enzyme catalyzing conversion of heme to biliverdin, leads to a reduction of the cellular pool of heme and heme containing proteins, thus removing potential pro-oxidant catalysts. Furthermore, bilirubin, the end product of the heme degradation pathway, is a molecule with antioxidant properties $(41,42)$. This combination of enzymatic and nonenzymatic sources provides an important protective system against various oxidant stresses. Normally, a balance exists between formation of AOS and antioxidants. However, oxidative stress, cell injury and disease may ensue after excessive production of oxidants or deficient functioning of antioxidant defenses $(3,10,39)$.

\section{Diseases Associated with Active Oxygen Species (AOS)}

Various pathological conditions are associated with AOS-mediated events, including cancer, aging, rheumatoid arthritis, various pulmonary disorders including adult respiratory distress syndrome (ARDS), and pulmonary fibrosis, ischemia-reperfusion injury, and immune complex-mediated disease $(1,3,7$, 18,43-45). Of these diseases, the involvement of AOS in carcinogenesis has been studied most intensely in a number of experimental models.

Carcinogenesis is a multi-stage process which classically is subdivided into several phases $(1,2)$. Initiation involves the interaction of a carcinogen with DNA resulting in a persistent lesion which can lead to mutations and heritable changes within the cell. Subsequently, selection and clonal proliferation of initiated cells occur during promotion. In the final stages of carcinogenesis, progression of benign lesions and subsequent genetic and phenotypic changes culminate in the establishment of a malignant neoplasm (1).

Strong evidence exists that AOS play an important role in all stages of tumorigenesis $(1,2,7,10,46-49)$. For example, direct interaction of AOS with DNA is implicated in the initiation and progressional stages of carcinogenesis $(1,3,47,48)$. AOS cause formation of oxidized bases $(7,8,10)$ and a spectrum of DNA lesions including base damage, single strand breaks, double strand breaks, crosslinking of DNA, and damage to the deoxyribose moiety (Figure 3, Table 1) $(10,50)$. Since neither $\mathrm{O}_{2}^{-}$nor $\mathrm{H}_{2} \mathrm{O}_{2}$ appear to cause strand breaks or base modifications in DNA under physiological conditions, it has been proposed that conversion of these species to $\mathrm{OH}$ in the presence of metal ions via a Fenton reaction is responsible for DNA damage $(9,10,51,52)$. A number of new techni- 
<smiles>N[C@H]1NC(=O)C2NC(=O)N[C@H]2N1</smiles>

8-OXOG<smiles>NC1CNCC(O)N1</smiles>

5-OHC<smiles>N[C@H]1NCN[C@@H](N)C1NC=O</smiles>

FAPYA

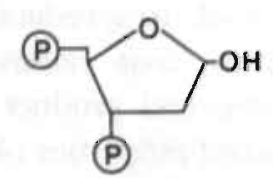

AP<smiles>CC1(O)NC(=O)NC(=O)C1(C)O</smiles>

TG<smiles>N[C@H]1NC[C@@H](NC=O)[C@@H](N)N1</smiles>

FAPYG

Figure 3. Structure of common base damages following exposure of DNA to ADS. Some of the known DNA lesions include: 8-oxoguanine (8-oxoG) or 8-oxoadenine (8-oxoA); thymine glycol (TG): 5-hydroxycytosine (5-OHC); apurinic/apyridinic abasic site (AP), 2,6-diamino4-hydroxy-5-formamidopyrimidine (FAPYG), 4,6-diamino-5-formamidopyrimidine (FAPYA), dihydrothymine. (DHT), 5-hydroxyuracil, (5-OHU).

ques have become available for sensitive measurement of oxidative lesions in DNA. For example, gas chromatography/mass spectrometry with selected ion monitoring can be used to characterize the spectrum of DNA damage after exposure to xenobiotics or AOS, thus providing a method for fingerprinting DNA damage (10). One of the most prevalent types of endogenous DNA damage is the oxidative lesion, 8-oxodeoxyguanine (8-oxoG), also referred to as 8-hydroxyguanine $(8,53)$. 8-oxoG is a major mutagenic lesion and a suspect lesion in the formation of both spontaneous cancers and those induced by a number of different agents. For example, 8-oxoG formation is observed in DNA after exposure to the known carcinogens, 4-nitroquinoline oxide, ionizing radiation, $\mathrm{KBrO}_{3}$, and 2-nitropropane (18,54).

The involvement of AOS in tumor promotion is indicated by studies showing that generating systems of AOS mimic some of the biochemical actions of tumor promoting compounds $(47,48,55)$. These effects include increased activity of ornithine decarboxylase (ODC), a rate limiting enzyme in the biosynthesis of polyamines integral to cell proliferation $(56,57)$, increased incorporation of ${ }^{3} \mathrm{H}$-thymidine (54), and activation of protein kinase C (PKC) (58). Moreover, phorbol ester tumor promoters can stimulate endogenous formation of AOS in several cell types and cause a decrease in cellular antioxidant defenses (7). 
Table 1. Commonly Detected DNA Base Damages Associated with Active Oxygen Species (AOS):

\begin{tabular}{|c|c|c|}
\hline Damage & Repair Pathways ${ }^{1}$ & Consequences \\
\hline 8-oxoguanine & $\begin{array}{l}\text { FAPY glycosylase(MutM) 8-oxoGC } \\
\text { 8-oxo GTPase(MutT) } \\
\text { A. glycosylase(MutY) } \\
\text { BER }^{2} \\
\text { NER }^{3}(?)\end{array}$ & $\mathrm{G} \rightarrow \mathrm{T}$ transversions \\
\hline 8-oxoadenine & $\begin{array}{l}\text { Not known } \\
\text { NER (?) }\end{array}$ & Not known \\
\hline FAPYG $^{4}$ & $\begin{array}{l}\text { FAPY glycosylase }(\text { MutM)/BER } \\
\text { NER (?) }\end{array}$ & Cytotoxic lesions \\
\hline FAPYA $^{5}$ & $\begin{array}{l}\text { FAPY glycosylase }(\text { MutM }) / \text { BER } \\
\text { NER (?) }\end{array}$ & None known \\
\hline Thymine glycol & Endonuclease III $(n t h) / B E R$ & Cytotoxic lesions \\
\hline Dihydrothymine & Endonuclease III $(n t h) / \mathrm{BER}$ & None known \\
\hline 5-hydroxycytosine & Not known & Not known \\
\hline 5-hydroxyuracil & Not known & $\mathrm{C} \rightarrow \mathrm{T}$ transitions \\
\hline Abasic sites & $\begin{array}{l}\text { AP endonucleases }(n t h, x t h, n f o) / B E R \\
\text { NER }\end{array}$ & Insertion of $A$ \\
\hline
\end{tabular}

${ }^{1}$ Most of the repair pathways have been characterized in E.coli (64). The E.coli genes encoding respective enzymes are italicized in parentheses. Homologous enzymes in mammalian cells have been identified, but have not been well characterized.; ${ }^{2} B E R=$ base excision repair $;{ }^{3} \mathrm{NER}=$ nucleotide excision repair $;{ }^{4}$ FAPYG $=2,6$-diamino-4-hydroxy-5formamidopyrimidine; ${ }^{5}$ FAPYA $=4,6$-diamino-5-formamidopyrimidine.

Lastly, it has also been shown that antioxidants are anticarcinogens and inhibit tumor promotion and/or progression in experimental models of carcinogenesis $(1,2,49,59)$.

The critical role of DNA repair in the prevention of cancer development is indicated by several syndromes in which specific repair pathways are blocked. The disease xeroderma pigmentosum (XP) is characterized by a defect in a nucleotide excision pathway which renders patients extremely sensitive to UV-induced DNA damage and skin cancer (60). Fibroblasts from patients with ataxia telangiectasia (AT) are hypersensitive to the lethal effects of ionizing radiation, implying that these cells are defective in the ability to process radiation-induced DNA damage (60). Moreover, patients with AT are extremely sensitive to X-rays and have an increased incidence of cancers of the lym- 
phoreticular system (60). Other repair deficiencies and their consequences in man have been reviewed elsewhere (60-62).

\section{Repair of Oxidative DNA Damage in Mammalian Cells}

Repaii of other biomolecules such as lipids and proteins may occur after oxidative injury, but most research has focused on mechanisms of DNA repair. AOS-induced DNA damage is not a rare event, and it is estimated that a human cell sustains an average of $10^{3}$ 'oxidative hits' per day due to cellular oxidative metabolism (63). However, DNA is functionally very stable, and the incidence of cancer is much lower than one would expect considering the high frequency of oxidative attacks. This protection is accomplished in part by a broad array of enzymes involved in the repair of DNA lesions (reviewed in 64-68). Table 1 summarizes DNA base damages and repair pathways associated with AOS and the known biological consequences of these base damages. The importance of these repair systems is indicated by the existence in cells of multiple enzymes involved in the repair of single lesions and the high degree of homology of DNA repair genes in various species.

Base damage induced by AOS can be repaired by two general pathways in both bacterial and mammalian cells. These include base excision repair and nucleotide excision repair (67). Base excision repair represents the removal of oxidative base damages by specific glycosylases followed by the action of apurinichapyrimidinic (AP) endonucleases which cleave the phosphodiester backbone resulting in the loss of the abasic sugar. The nucleotide gap is than filled in and sealed by the action of DNA polymerase and DNA ligase.

The five general steps in the base excision repair pathway of DNA damage in bacterial and mammalian cells are shown in Figure 4. Base damage is recognized by a glycosylase which excises the base resulting in an abasic site. The cell contains many glycosylases, some of which also contain AP-endonuclease activity recognizing a specific type of base damage. Abasic sites are recognized by endonucleases. Dual action of '5' and $3^{\prime}$ AP-endoncleases and/or subsequent action of $5^{\prime} \rightarrow 3^{\prime}$ 'exonuclease generates gaps in the strand. During the resynthesis step, DNA polymerase fills in these gaps, and DNA ligase seals the strand and completes the DNA repair process.

Base excision repair is also referred to as "short patch repair" as it involves resynthesis of 1-3 nucleotides. Another repair pathway of DNA damage which exists in both bacterial and mammalian cells involves resynthesis of larger patches of DNA, thus is referred to as "long patch" or nucleotide excision repair (69). The molecular events of this repair process have not been well characterized in mammalian cells, but involve the coordinate action of a number of different proteins at sites of numerous bulky DNA lesions. 
Several other repair enzymes are induced in mammalian cells in response to DNA damage (70-73). DNA strand breaks induced by a variety of oxidants activate a nuclear enzyme (poly-ADP ribose polymerase) involved in repair of DNA lesions $(72,74,75)$. However, activation of this enzyme diminishes cellular NAD and ATP levels and is associated with decreased cell survival (75). Inhibition of poly-ADP ribose polymerase activity in mammalian cells exposed to lethal concentrations of $\mathrm{H}_{2} \mathrm{O}_{2}$ prevents the sequence of events that eventually lead to cell lysis (72). These observations illustrate a circumstance where induction of a DNA repair enzyme is associated with cell injury and death $(72,75)$.
1. RECOGNITION

(base damage

specific-glycosylase)

2.<smiles>C[Si](C#N)(ON)ON</smiles>

(AP-endonuclease)

3. EXCISION

(Removal of the AP-site)

$\downarrow$

4. RESYNTHESIS

(DNA-polymerase)

5.

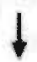

LIGATION

(DNA ligase)

Figure 4. Base excision repair of DNA damage in mammalian cells.

\section{Alterations in Gene Expression and Proteins After Specific Oxidative Stresses in Mammalian Cells}

After exposure to oxidants, mammalian cells may express stress-induced genes or genes encoding antioxidant enzymes and related proteins. One approach used to elucidate alterations in gene expression following oxidative stress is subtractive hybridization $(76,77)$. In this method, RNA isolated from cells exposed to oxidants is hybridized to RNA from control cells, and unique RNA species which remain present following the subtraction process can be used to elucidate genes expressed selectively after AOS exposure (78).

Other investigators have used two-dimensional gel electrophoresis to determine alterations in protein synthesis after oxidative stress $(79,80)$. Moreover, several laboratories have studied the appearance of new enzymes or altered enzymatic activities (81). With the use of these techniques, molecular responses have been investigated after exposure to various oxidant stresses including UV radiation, ionizing radiation, phorbol ester tumor promoters and hyperoxia. Some patterns of response after exposure to various agents are similar (82). However, other pathways of activation appear to be unique to the type of oxidative stress. Some recent findings and their implications in adaptation and/or disease are described below. 


\section{Ultraviolet (UV) Radiation}

Exposure to UV causes intracellular production of AOS (20) and formation of thymidine dimers which are repaired through a "long patch" nucleotide excision repair pathway (83). The 'UV response' has been defined as the spectrum of genetic changes in mammalian cells following irradiation with UV (or treatment with other DNA damaging agents) including increased expression and amplification of UV-responsive genes (82). Cellular responses to UV have been divided into three phases: 1) primary interactions between the DNA damaging agent and the cell; 2) signal transduction and molecular targeting; and 3) long-lasting cellular consequences $(82,84)$.

Several pieces of evidence support the hypothesis that DNA is the primary target of the UV response. For example, induction of gene expression in XP skin fibroblasts requires a much lower dose of $\mathrm{UV}$ than that required in normal skin fibroblasts. Moreover, transfection of oxidant-damaged DNA into a cell elicits the UV response $(82,84)$.

Exposure to UV also causes activation of gene regulatory factors intrinsic to cellular replication including transcription factors binding to UV-responsive elements (URE) (82,84-87). Moreover, UV activates several transcription factors (i.e., AP-1 and NFkB) by post-translational modification $(82,84)$.

UV radiation also induces a number of proto-oncogenes, including c-fos and c-myc in a variety of cell types $(84,88,89)$. Since increases in mRNA expression of $\mathrm{c}$-fos have been reported in $\mathrm{CHO}$ cells after exposure to a number of DNA-damaging agents, including UV radiation, increased c-fos expression may be a general stress response of the cell (88). In addition to induction of certain proto-oncogenes, UV stimulates levels of p53 cellular tumor antigen, a potent transcription factor that also mediates arrest of the cell cycle at G1 $(90,91)$.

Several DNA damage-inducible transcripts have been identified using subtractive hybridization in mammalian cells following UV exposure (77). In CHO cells, two of 20 sequenced clones matched known gene sequences identified as metallothionein (MT) I and II. The induced transcripts could be separated into two general classes: class 1 transcripts [induced specifically by UV irradiation and $\mathrm{N}$-acetoxy-2-acetylaminofluorine (AAAF)] and class 2 transcripts [induced by UV irradiation, AAAF and methyl methanesulfonate (MMS)]. Many class 2 transcripts were also induced by $\mathrm{H}_{2} \mathrm{O}_{2}$ and various alkylating agents, but not by heat shock, phorbol ester or DNA-damaging agents not producing high levels of base damage. Induction of these DNA damage-inducible (DDI) transcripts is most likely a direct response to DNA damage since induction is rapid and occurs only after exposure to certain types of DNA damaging agents (77). In other studies, MT I and MT II are rapidly and coordinately induced by UV $(84,92,93)$ but not by $\mathrm{X}$-rays and $\mathrm{H}_{2} \mathrm{O}_{2}(92)$. Thus, $\mathrm{MT}$ induction appears to be fairly specific to the UV response (92). The signals responsible for induction of class 
1 or 2 transcripts are unknown. Class 1 transcripts may be induced by helical distortion or a step in the nucleotide excision repair pathway whereas class 2 transcripts may be induced by agents which induce high levels of base damage in DNA (UV, MMS, AAAF, $\mathrm{H}_{2} \mathrm{O}_{2}$ ) and other alkylating agents (77).

In most cells, one effect of DNA damage is a transient inhibition of DNA synthesis and arrest of cell growth (94). Several of the class 2 transcripts expressed after UV exposure (77) encode transcripts increased by other growth cessation signals (94). The genes encoding for these transcripts are designated as gadd (growth arrest and DNA damage inducible) and may be coordinately regulated. Gadd genes may represent part of a novel regulatory pathway involved in the negative control of mammalian cell growth $(94,95)$. Although UV-mediated damage is associated with growth arrest and leads to induction of growth arrest (gadd) transcripts, UV also paradoxically stimulates increased expression and activity of ODC, an enzyme involved in proliferation (96-98). ODC is a rate-limiting enzyme in the synthesis of polyamines, essential for cellular division and growth (99).

Increased expression of various proteases, including collagenase and plasminogen activator (PA), have been demonstrated in a variety of cell types following UV exposure $(84,100,101)$. PA is induced by UV in human fibroblasts deficient in repair of UV-induced DNA damage, but not in repair-proficient cells $(100,101)$. Inhibition of DNA repair potentiates UV-stimulated PA induction, suggesting the importance of prolonged DNA damage in inducibility of PA (101).

UV A (320-380 nm) radiation, $\mathrm{H}_{2} \mathrm{O}_{2}$, sodium arsenite, cadmium chloride and menadione induce a $32 \mathrm{kD}$ stress protein in human skin fibroblasts identified as heme oxygenase $(41,42,102)$. Heme oxygenase plays an essential role in heme catabolism by cleaving heme to biliverdin which is subsequently converted to bilirubin by biliverdin reductase (42). Bilirubin is an effective scavenger of singlet oxygen and is able to react with $\mathrm{O}_{2}^{-}$and peroxyl radicals. Moreover, when bound to albumin, bilirubin can prevent oxidative damage to albumin and prevent lipid peroxidation of albumin-bound fatty acids (42). Thus, induction of heme oxygenase may constitute an important cellular defense mechanism against oxidative damage.

A probable signal for induction of heme oxygenase appears to be modified or reduced levels of GSH $(42,103)$. Thus, induction of heme oxygenase may contribute to cell defense provided by endogenous GSH against the cytotoxic consequences of UV A and $\mathrm{H}_{2} \mathrm{O}_{2}$. Since induction of heme oxygenase and cell death in human skin fibroblasts by these agents can be prevented by addition of the iron chelators, o-phenanthroline or desferrioxamine, generation of $\mathrm{OH} \cdot$ by an iron-catalyzed Haber Weiss reaction is probably involved in both induction of the stress response and cell killing (104). Agents which induce heme oxygenase can be categorized as either oxidants and/or substances modifying 
cellular glutathione levels (105). High resolution two-dimensional gel electrophoresis has also been used to study protein synthesis occurring after exposure of human fibroblasts or keratinocytes to UV C (200-290 nm) or other DNA damaging agents (79). UV, some alkylating agents, and chemical carcinogens induce synthesis of human major histocompatibility class-1 (MHC-1) proteins. Thus, one possible consequence of induction of MHC-1 is targeting of damaged cells for immune recognition and somatic cell selection (79). The proinflammatory cytokine, interleukin-1 (IL-1), also is induced after exposure of keratinocytes to UV (106).

In summary, DNA damage appears to be a critical event in governing responses of cells to UV-induced damage. Certain genes affected by UV contain regulatory elements (UREs) in their promoter region which control transcription. Genes induced after UV exposure are diverse and appear related to both increases in proliferation (protooncogenes, ODC) and arrest of cell growth (gadd genes). Other genes (MT and heme oxygenase) may be associated with antioxidant defense mechanisms or stimulation of immune responses.

\section{Ionizing Radiation}

Exposure to ionizing radiation leads to formation of $\mathrm{OH}$ as a result of homolytic fission of oxygen-hydrogen bonds in water $(10,62)$. The carcinogenic effects of ionizing radiation may be mediated by base pair changes and frame shift mutations (10). Accordingly, expression of several genes is altered in Syrian hamster embryo cells following low doses of ionizing radiation (neutrons, $\mathrm{X}$-rays or gamma rays). Levels of $\beta$-actin-specific mRNA decrease within 15 minutes after exposure, and a decrease in accumulation of ODC mRNA is observed within 1 hour (107). Down-regulation of these genes may be associated with the arrest in DNA synthesis observed in fibroblasts and other cell types following exposure to high doses of radiation $(107,108)$.

Inhibition of replication after ionizing radiation may be mediated by a transacting factor enabling cells to repair radiation damage (109). In this respect, ionizing radiation and AOS-generating compounds cause the appearance of a 43 $\mathrm{kD}$ DNA binding protein in human cells which may function as a negative regulator, reducing transcription of several genes (110).

The effect of ionizing radiation on transcription and c-fos gene expression has been studied in normal and radiation-sensitive mice bearing an autosomal recessive mutation and developing a disease similar to AT in humans (111). Immediately after irradiation, total transcription and c-fos expression is depressed in gut tissue of repair-proficient mice. However, transcription is doubled and depression of c-fos mRNA is delayed in radiation-sensitive mice suggesting abnormal regulation following exposure to ionizing radiation. A 
trans-acting factor defective or absent in cells from radiation-sensitive mice may be responsible for transcriptional inhibition in cells following radiation exposure $(108,110)$.

The proinflammatory cytokines, TNF and $\mathrm{IL}-1$, are produced by a number of different cell types in response to ionizing and UV radiation and other stimuli $(103,106,112-114)$. These cytokines activate inflammatory cells resulting in an oxidative burst. In addition, TNF causes conversion of intracellular xanthine dehydrogenase into xanthine oxidase thereby increasing the AOS-generating ability of the cell $(16,115)$. Cytotoxic effects of TNF are ameliorated under anaerobic conditions and by antioxidants, and cell lines resistent to the cytotoxic effects of TNF exhibit increased levels of antioxidants (115-117). A number of transcription factors, including NFkB and AP-1 (c-fos/c-jun), also are activated after exposure to TNF. TNF also up-regulates expression of the gro, c-fos, c-jun and c-myc oncogenes (115-117).

Recently, several investigators demonstrated that TNF, IL-1, and bacterial lipopolysaccharide (LPS) selectively induce the mitochondrial enzyme, MnSOD (118-122). MnSOD may be an important determinant of resistance to TNF and mitochondrially generated $\mathrm{O}_{2}^{-}$, a key component of TNF-mediated cell killing $(118,119,123)$. The importance of MnSOD in defense against oxidative stress has been shown in yeast mutant strains lacking MnSOD (124). In the absence of oxygen, mutants grow as rapidly as wild type cells, but increasing oxygen concentrations lead to growth inhibition. This study provides direct evidence that MnSOD contributes to cellular protection from oxygen toxicity (123).

Rats pretreated with TNF and IL-1 before exposure to hyperoxia show less pulmonary injury and mortality in comparison to hyperoxia-exposed rats. This adaptation to hyperoxic injury is associated with increased activity of antioxidant enzymes in lung $(125,126)$. In addition to MnSOD, TNF also up-regulates expression of other genes (ferritin, MT) which might have protective functions (115). On the other hand, TNF also can induce a program of self destruction (apoptosis) involving DNA fragmentation (115). Thus, some cytokines may cause either increases in antioxidant defense mechanisms or cell killing.

\section{Phorbol Ester Tumor Promoters}

Phorbol ester compounds are powerful activators of $\mathrm{O}_{2}^{-}$and $\mathrm{H}_{2} \mathrm{O}_{2}$ production in phagocytes (7). These tumor promoters exert their biological effects by inducing an altered program of gene expression involving activation of PKC and the transcription factor, AP-1 (127-130). 
Modulation of gene expression in response to the potent tumor promoter, 12-O-tetradecanoyl phorbol-13-acetate (TPA), has been examined in normal human fibroblasts after construction of cDNA libraries (93). cDNA clones were found which code for a precursor form of the secreted protein XHF1, a product of the collagenase gene $(93,131)$. The sequence of another clone corresponded in part with the sequence of the metallothionein Ila (MT II) gene. The use of cycioheximide to examine the involvement of protein synthesis in the induction of gene expression by TPA revealed that some genes (MT II) respond directly, whereas activation of others (XHT1) requires protein synthesis $(81,93)$.

In mouse epidermis, application of TPA induces expression of several mRNA species (132). Of 56 isolated cDNA clones, 32 were identical to MT I and II or endogenous retroviral-like sequences (VL30). Immunohistochemistry and time kinetic studies on mRNA levels in mouse epidermis showed that increases in MT and VL30 mRNAs coincided in time with a TPA-induced transient block in basal cell proliferation (132). However, increases in mRNA expression of c-fos and ODC were observed at early time points.

Aside from the role of MTs in heavy metal detoxification, MTs maintain cellular $\mathrm{Zn}^{2+}$ homeostasis and are thought to be indirectly involved in the regulation of a variety of $\mathrm{Zn}^{2+}$-dependent processes, e.g. transcription, DNA replication, DNA repair and protein synthesis. Thus MT expression in mouse epidermis after TPA treatment may be linked mechanistically with a transient block in DNA synthesis as opposed to enhanced proliferation (132). In these experiments, MT mRNA levels and immunoreactive protein return to control levels after 24 hours, a timepoint when the epidermis undergoes proliferation. mRNA levels of glyceraldehyde-3-phosphate dehydrogenase (GAPDH) increase at times correlating with TPA-induced hyperproliferation. Thus, increased GADPH expression is most likely associated with an enhanced rate of cell proliferation (132).

Increased expression of proteases also occur in cells after TPA exposure (133). Fibroblasts from patients with XP or AT show increased expression of procollagenase and prostromelysin, extracellular matrix-degrading metalloproteinases. Altered expression of these proteases could play an important role in the pathogenesis of tumors in individuals with these genetic diseases (133). In summary, the increased expression of MT and proteases after exposure to TPA mimic, in part, the pattems of cellular response observed after exposure of various cell types to UV and ionizing radiation.

\section{Hyperoxia}

Cellular remodeling occurring in the lung in response to hyperoxic injury also may be due to changes in gene expression resulting in the synthesis of new 
proteins. Subtractive hybridization of RNA from hyperoxic and control rabbit lungs yields three hyperoxia-induced clones (76). One clone was identified as a tissue inhibitor of metalloproteinases (TIMP), synthesized and secreted by a variety of cell types including fibroblasts, macrophages and erythroid colonyforming blood cells. The role of TIMP in the response to lung injury remains to be elucidated, but may be important in remodeling of the extracellular matrix. Other clones induced after hyperoxia were identified as MT II (134) and surfactant protein A (sp-A) (135).

Exposure of rodents to hyperoxia for prolonged periods of time can be fatal, dependent on the age of the animal and the exposure regimen. However, pretreatment of adult rats with TNF and $\mathrm{LL}-1$ prior to hyperoxia (>99\%) causes an adaptive response resulting in tolerance to subsequent high oxygen concentrations $(125,126)$. This adaptive response, attributed to increased lung antioxidant defenses, is also observed after pretreatment of rats with LPS (136), sublethal levels of hyperoxia (137), normobaric or hypobaric hypoxia (138), cadmium (139) or ozone (140). Transgenic mice overexpressing CuZnSOD show decreased mortality after exposure to hyperoxia in comparison to control animals (141). Increased survival was more pronounced in the young (2.5 months of age) animals compared to older (5.5 months of age) mice (141). Moreover, administration of polyethylene glycol (PEG)-conjugated, or liposome-encapsulated antioxidant enzymes to rodents or to lung cells in vitro protects against hyperoxia-induced toxicity (142-145). These observations may be important in designing clinical strategies for prevention of pulmonary oxygen toxicity.

Studies examining regulation of antioxidant enzymes in cells of the lung after exposure to hyperoxia demonstrate variable changes in gene expression, immunoreactive proteins and activities of antioxidant enzymes. Regulation is complex and appears to be exerted at different levels (146). After 3 and 5 days of exposure to $85 \%$ hyperoxia, adult rats show increased MnSOD mRNA levels in lung which return to baseline levels by 14 days. No changes in CuZnSOD or catalase mRNA levels are observed (147).

Discrepancies in documented responses of cells in vitro to hyperoxia may occur because endogenous levels of certain antioxidant enzymes diminish after cell isolation (148). Exposure of rat pulmonary epithelial or fibroblast cell lines to hyperoxia for 24 hours has no effect on CuZnSOD or MnSOD mRNA levels (122). Alternatively, increases in mRNA levels, protein and activity of $\mathrm{CuZnSOD}$, as well as increases in GPX mRNA levels and enzyme activity are observed in human endothelial cells following hyperoxic exposure for 3 or 5 days (146). Although catalase mRNA increases, immunoreactive protein and enzyme activity are decreased. Variable increases in MnSOD mRNA, but no changes in MnSOD activity, are demonstrated revealing the complex nature of regulation of antioxidant enymes following hyperoxic exposure. 
Recent reports also show increases in gene expression and activities of antioxidant enzymes, including $\mathrm{MnSOD}$ and $\mathrm{CuZnSOD}$ in rat lungs after ozone exposure $(21,149)$, a reactive environmental pollutant which also generates AOS.

\section{Mineral Dusts}

Occupational exposure to mineral dusts such as asbestos or silica can lead to a variety of pulmonary disorders including malignant and nonmalignant disease (150). Experimental studies indicate that AOS may act at various stages in the pathogenesis of these diseases $(13,151,152)$. For example, AOS can be generated in the lung after encounter of phagocytic cells (macrophages and neutrophils) with these minerals and consequent phagocytosis of particles. These cells then undergo a respiratory burst that may be prolonged after exposure to larger fibers or particles which are incompletely phagocytized (13,153). Moreover, some fibrogenic minerals generate AOS by acellular mechanisms. For example, asbestos fibers, many of which contain iron, generate $\mathrm{AOS}$ at the surface in a Fenton-like reaction (154-156). Similarly, silica, especially when freshly ground, can release AOS catalysed by redox reactions on the particle surface $(157,158)$.

Evidence for a role for AOS in mineral dust-induced pulmonary toxicity and disease stems from numerous studies (reviewed in 152). Cytotoxicity and lipid peroxidation caused by asbestos or silica in vitro can be prevented or diminished by concomittent exposure to antioxidants (151, 159-161). Moreover, administration of PEG-conjugated catalase to rats during inhalation of asbestos ameliorates pulmonary toxicity, inflammation and the extent of pulmonary fibrosis (162). Since AOS appear to be important mediators of asbestos or silica-induced toxicity, we investigated the gene expression, protein and enzyme activities of antioxidant enzymes in rat lungs after inhalation of the fibrogenic dusts, crocidolite asbestos or cristobalite silica. These animal models of pulmonary fibrosis show specific alterations in gene expression of antioxidant enzymes which may involve post-translational modification (163). For example, inhalation of crocidolite asbestos causes increases in steady-state mRNA levels of MnSOD, catalase and GPX, increases in immunoreactive proteins, and overall increases in enzyme activities. However, striking and more dramatic increases in MnSOD mRNA and immunoreactive protein are observed after inhalation of the silicon dioxide particle, cristobalite, although increases in enzyme activity of total SOD (both MnSOD and CuZnSOD) are not observed (163). Immunocytochemical localization of MnSOD reveals selective localization in the mitochondria of type II epithelial cells, whereas, other cell types exhibit little accumulation of MnSOD immunoreactive protein (164). Increased 
gene expression and protein levels of MnSOD in whole lung tissue is directly related to the extent of lung inflammation in these models $(163,164)$, an observation supporting the concept that MnSOD is a sensitive indicator of pulmonary inflammation and lung injury.

Since TNF is causally implicated in the development of silicosis (165), and this cytokine selectively induces mRNA expression of MnSOD in a number of cell types, we also examined gene expression of TNF in the lungs of these animals. Both crocidolite and cristobalite inhalation caused increases in steady state mRNA levels of TNF in rat lung indicating that increases in MnSOD mRNA levels might be mediated by TNF (166).

Examination of human pleural mesothelial cells, the progenitor cells of mesothelioma in vitro, shows that both crocidolite and chrysotile asbestos, as well as the AOS-generating system, xanthine plus xanthine oxidase, cause increases in mRNA levels of MnSOD and heme oxygenase whereas CuZnSOD is unaffected (167). Moreover, comparative experiments using human lung fibroblasts show similar but less striking induction of MnSOD and heme oxygenase after exposure to these oxidant stresses (167). Interestingly, human mesothelial cells are more sensitive than human lung fibroblasts to the cytotoxic effects of asbestos or xanthine/xanthine oxidase indicating that increases in antioxidant defenses in mesothelial cells are not sufficient to protect these cells from asbestos-induced damage.

The studies described above demonstrate that exposure to fibrogenic mineral dusts causes increases in specific antioxidant enzymes, most notably MnSOD. However, exposure to asbestos at nontoxic concentrations also results in increased steady state mRNA levels of ODC, a marker of cell proliferation in rat lung (168). Antioxidants can inhibit asbestos-induced ODC mRNA expression and activity, indicating the importance of AOS in asbestos-induced ODC activation and cell replication (55). Asbestos also appears to cause cell proliferation by persistent induction of c-jun and/or c-fos protooncogenes and AP-1 DNA binding activity in tracheal epithelial cells and pleural mesothelial cells (169). Whether persistent induction of the early response gene pathway by asbestos is mediated by AOS is currently under investigation.

\section{Genetic Regulons Induced After Oxidative Stress}

Genetic elements responsible for induction of proteins or enzymes after oxidative stress in mammalian cells have not been well characterized. However, a number of distinct regulons governing responses to oxidative stress have been identified in bacterial cells (170-174). For example, the SoxR and OxyR regulons are activated in bacteria after exposure to $\overline{\mathrm{O}_{2}}$ and $\mathrm{H}_{2} \mathrm{O}_{2}$, respectively 
(170,171). A number of signaling molecules indicative of oxidative stress also have been identified $(175,176)$.

The aromatic hydrocarbon [Ah]-responsive gene battery may represent a coordinated response system to oxidative stress and DNA damage which resembles the SOS response in bacteria. (22). Several regulatory elements referred to as aromatic hydrocarbon responsive elements (AhRE), xenobiotic responsive elements (XRE), and antioxidant responsive elements (ARE), have been identified in genes of the Ah family $(22,177-179)$. More detailed analysis of the ARE has shown that they are responsive to $\mathrm{H}_{2} \mathrm{O}_{2}$ and phenolic antioxidants undergoing redox cycling. Thus, ARE could represent part of a signal transduction pathway allowing eukaryotic cells to respond to oxidative stress (180).

Proteins which bind to AhRE, XRE or ARE elements remain to be identified. Some evidence exists that gene activation occurs after post-translational modification of a protein constitutively bound to the ARE after interaction with electrophilic or redox active compounds. These interactions may then lead to altered conformation of the trans-acting protein and increased transcription of the gene (179).

Interestingly, a similar mechanism of gene activation following oxidative stress has been characterized in bacteria. AOS, by altering the redox state of constitutively bound OxyR protein, change its conformation and activate transcription of $\mathrm{H}_{2} \mathrm{O}_{2}$-inducible genes (170).

Studies using mice with deletion of a fragment of chromosome 7 indicate that this portion of the chromosome contains regulatory elements modulating basal and inducible expression of a number of genes located on other chromosomes (22). A gene in the deleted portion of this chromosome might encode a trans-acting positive regulatory factor for induction of MT and other genes, as well as a trans-acting negative regulatory factor (repressor) for induction of certain genes of the Ah battery (22). Interestingly, three of the class II transcripts previously identified after UV-induced DNA damage and gadd transcripts in CHO cells $(77,94)$ are also markedly elevated in these mice indicating some overlap of these regulatory pathways (22). This missing region of mouse chromosome 7 may contain a master gene "switch" that responds to oxidative stress (22).

Another posi-translational modification which could activate gene expression is protein phosphorylation. For example, activation of PKC occurs after exposure to various oxidants (TPA, asbestos, UV, ionizing radiation) $(181,182)$. The ability of PKC to activate the transcription factor, AP-1, demonstrates a second messenger pathway leading directly to altered expression of distinct sets of genes $(82,183,184)$.

As discussed previously, several classes of DNA damage inducible (DDI) and growth arrest and DNA damage inducible (gadd) genes have been identified. Furthermore, genes induced by UV or TPA contain elements (UREs and TREs, 
respectively) which control expression of these genes $(127,129,131)$. These observations indicate the existence in mammalian cells of distinct genetic elements involved in responses to oxidative stress. Undoubtedly, a finite number of other regulons involved in responses to oxidant injury remain to be elucidated.

\section{Summary}

A broad array of oxidative stresses modulates gene expression in a variety of mammalian cells. One goal of this review was to characterize cellular responses to oxidative injury, how these processes are regulated, and the outcome for a particular cell or tissue. Many genes induced in response to specific oxidant stresses have been identified and include transcription factors, replication proteins, proteases, protease inhibitors, proteins affecting cell proliferation and various antioxidants, i.e. heme oxygenase, MT, and MnSOD. The latter enzyme is induced after a number of cytokines and oxidant stresses including hyperoxia and mineral dusts causing inflammation (118-120,147,163). Moreover, increases in mRNA levels of TNF and IL-1, cytokines inducing MnSOD, are observed after exposure to UV and ionizing radiation $(106,113,183)$. Since increased electron flow could lead to generation of more AOS within mitochondria, increased levels of MnSOD might be necessary to maintain normal functioning of the mitochondria after oxidative stress.

Alterations in cell growth are intrinsically related to the pathogenesis of many diseases. Paradoxically, some of the responses of cells to oxidative stress reflect cytotoxicity and cytostasis, whereas others result in increased cell proliferation. For example, induction of gadd genes observed after oxidative stress is related to growth arrest of cells (94), a response which might enable the cell to repair oxidative damage prior to replication. This phenomenon might prevent fixation of mutations associated with oxidative DNA damage. On the other hand, increased mRNA expression and activity of ODC, observed after exposure of cells to UV (96-98) or asbestos (55) is associated with increased cell proliferation. In addition, increased mRNA expression of cellular proto-oncogenes observed after exposure to oxidants $(185,186)$ could also be related to increased DNA synthesis or proliferation.

Figure 5 provides a general scheme of cell responses to oxidative stress and possible ramifications. AOS can react with a number of target molecules including proteins, lipids, and DNA. These interactions elicit a number of signals including activation of gene regulatory factors (transcription factors) which in turn activate oxidative stress-responsive genes or regulons. Consequently, a number of proteins are produced with distinctive functions including DNA repair enzymes, antioxidants, proteases or protease inhibitors, cytokines 


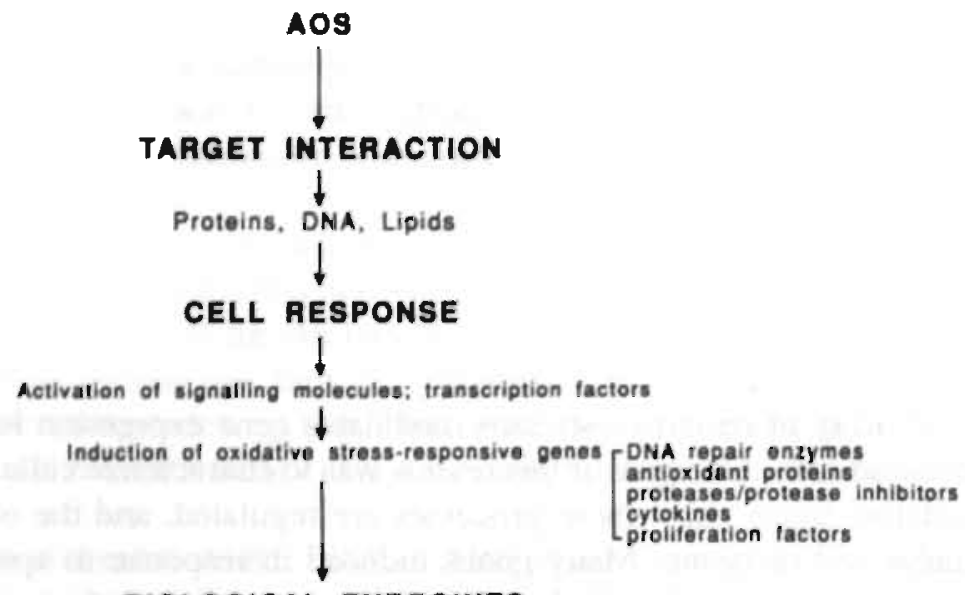

BIOLOGICAL ENDPOINTS

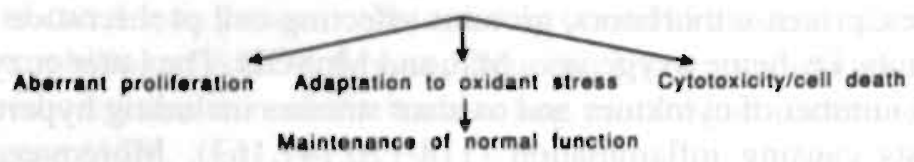

Figure 5. Summary of cell responses to oxidative damage in relationship to homeostasis and the development of disease.

and proteins affecting cell proliferation. These cellular responses to AOS can lead to restoration of normal cellular function and adaptation to oxidative stress, cell death or aberrant proliferation. It is the latter two responses which can lead to a variety of disease states including cancer. The overall outcome of the cellular response to oxidative stress is complex and might depend on the status of cellular diffentiation and phase of the cell cycle and/or antioxidant content.

Expression of genes and synthesis of new proteins in response to oxidative stress appear to be, for the most part, cell- and tissue-specific (81). Subtractive hybridization studies have yielded multiple cDNA clones encoding mRNA transcripts which are either increased or induced after oxidative stress. Identification of these clones might improve our understanding of cellular responses to oxidative stresses and their implications in repair of oxidative damage and adaptation to injury.

\section{Acknowledgments}

The authors thank Rhoda Rowell and Barbara Cady for preparing the manuscript and Judith Kessler for providing the illustrations. This work was supported by grants from NIH (RO1 HL39469) and the EPA to B.T. Mossman and a grant from NIH FIRST (CA50681) to B. Van Houten. 


\section{REFERENCES}

1. Sun Y. Free radicals, antioxidant enzymes, and carcinogenesis. Free Rad Biol Med 1990;8:583-599.

2. Perchellet JP, Perchellet, EM. Antioxidants and multistage carcinogenesis in mouse skin. Free Rad Biol Med 1989;7:377-408.

3. Farber JL, Kyle ME, Coleman JB. Biology of Disease. Mechanisms of cell injury by activated oxygen species. Lab Invest 1990;62:670-679.

4. Pryor WA, Godber SS. Oxidative stress status: an introduction. Free Rad Biol Med 1991;10:173-174.

5. Messina MJ. Oxidative stress status and cancer: methodology applicable for human studies. Free Rad Biol Med 1991;10:175-176.

6. Pryor WA, Godber SS. Noninvasive measures of oxidative stress status in humans. Free Rad Biol Med 1991;10:177-184.

7. Trush MA, Kensler TW. An overview of the relationship between oxidative stress and chemical carcinogenesis. Free Rad Biol Med 1991;10:201-210.

8. Shigenaga MK, Ames BN. Assays for 8-hydroxy-2'-deoxyguanosine: a biomarker of in vivo oxidative DNA damage. Free Rad Biol Med 1991;10:211-216.

9. Dizdaroglu $\mathbf{M}$. Chemical determination of free radical-induced damage to DNA. Free Rad Biol Med 1991;10:225-242.

10. Halliwell B, Aruoma OI. DNA damage by oxygen-derived species. Its mechanism of action and measurement in mammalian systems. FEBS Letters 1991;281:9-19.

11. Bandy B, Davison AJ. Mitochondrial mutations may increase oxidative stress: implications for carcinogenesis and aging. Free Rad Biol Med 1990;8:523-539.

12. Cross CE, Halliwell B, Borish ET, Pryor WA, Ames BN, Saul RL, et al. Oxygen radicals and human disease. Ann Int Med 1987;107:526-545.

13. Mossman BT, Marsh JP, Shatos MA, Doherty J, Gilbert R, Hill S. Implication of active oxygen species as second messengers of asbestos toxicity. Drug Chem Toxicol 1987; $10: 157-180$.

14. Angermuller S, Bruder G, Volkl A, Wesch H, Fahimi HD. Localization of xanthine oxidase in crystalline cores of peroxisomes. A cytochemical and biochemical study. Eur J Cell Biol 1987;45:137-144.

15. Till GO, Friedl HP, Ward PA. Lung injury and complement activation: Role of neutrophils and xanthine oxidase. Free Rad Biol Med 1991;10:379-386.

16. Friedl HP, Till GO, Ryan US, Ward PA. Mediator-induced activation of xanthine oxidase in endothelial cells. FASEB J 1989;3:2512-2518.

17. Beckman JS, Beckman TW, Chen J, Marshall PA, Freeman BA. Apparent hydroxyl radical production by peroxinitrite: Implications for endothelial injury from nitric oxide and superoxide. Proc Natl Acad Sci USA 1990;87:1620-1624.

18. Floyd RA. Role of oxygen free radicals in carcinogenesis and brain ischemia. FASEB J 1990;4:2587-2597.

19. Freeman BA, Crapo, JD. Biology of Disease. Free radicals and tissue injury. Lab Invest $1982 ; 47: 412-426$.

20. Moares EC, Keyse SM, Tyrell RM. Mutagenesis by hydrogen peroxide treatment of mammalian cells: a molecular analysis. Carcinogenesis 1990;11:283-293.

21. Mustafa MG. Biochemical basis of ozone toxicity. Free Rad Biol Med 1990;9:245-265. 
22. Nebert DW, Petersen DD, Fornace Jr. AJ. Cellular responses to oxidative stress: the [A.H] gene battery as a paradigm. Environ Health Perpect 1990;88:13-25.

23. Mehrotra S, Kakkar $\mathbf{P}$, Viswanathan PN. Mitochondrial damage by active oxygen species in vitro. Free Rad Biol Med 1991;10:277-285.

24. Jeejeebhoy, KN. In vivo breath alkane as a index of lipid peroxidation. Free Rad Biol Med 1991;10:191-194.

25. Olivier CN: Inactivation of enzymes and oxidative modification of proteins by stimulated neutrophils. Arch Biochem Biophys 1987;253:62-72.

26. Sharonov B, Churilova IV. Oxidation of superoxide dismutase by stimulated neutrophils. Generation of new protein stuctures with catalytic activity. Free Rad Biol Med 1990;9:137 (abstr)

27. White AA, Crawford KM, Pati CS, Lad PJ. Activation of soluble guanylate cyclase from rat lung by incubation or by hydrogen peroxide. J Biol Chem 1976;251:7304-7312.

28. Kono Y, Fridovich I. Superoxide radical inhibits catalase. J Biol Chem 1982;257:57515754.

29. Aruoma OI, Halliwell B. Reaction of $\mathrm{HOCl}$ with superoxide dismutase, catalase, glutathione peroxidase and ebselen. Free Rad Biol Med 1990;9:136 (abstr).

30. Bray RC, Cockle SH, Fielden EM, Roberts PB, Rotilio G, Calabrese L. Reduction and inactivation of superoxide dismutase by hydrogen peroxide. Biochem J 1974;139:43-48.

31. Blech DM, Borders CL Jr. Hydroperoxide anion, HO-2, is an affinity reagent for the inactivation of yeast $\mathrm{Cu}, \mathrm{Zn}$ superoxide dismutase: modification of one histidine per

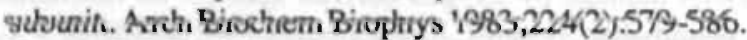

32. Terada LS, Leff JA, Guidot DM, Willingham IR, Repine JE. Inactivation of xanthine oxidase by hydrogen peroxide involves site directed hydroxyl radical formation. Free Rad Biol Med 1991;10:61-68.

33. Halliwell B, Gutteridge JMC. Free Radicals in Biology and Medicine, Oxford, Clarendon Press, 1989.

34. Heffner JE, Repine JE. Antioxidants and the lung. In Crystal RG, West JB, Barnes PJ, Chernlack NS, Weibel ER, editors. The Lung: Scientific Foundations, New York; Raven Press $_{11991: 1811 .}$

35. Marklund SL. Extracellular superoxide dismutase and other superoxide dismutase isoenzymes in tissues from nine mammalian species. Biochem J 1984;222:649-655.

36. Keller GA, Wamer TG, Steimer KS, Hallewell RA. Cu,Zn superoxide dismutase is a peroxisomal enzyme in human fibroblasts and hepatoma cells. Proc Natl Acad Sci USA 1991;88:7381-7385.

37. Crapo JD, Oury T, Rabouille C, Slot JW, Chang LJ. Copper,zinc superoxide dismutase is primarily a cytosolic protein in human cells. Proc Natl Acad Sci USA 1992;89:1040510409.

38. Wispé JR, Clark JC, Burhans MS. Kropp PE, Korfhagen TR, Whitsett JA. Synthesis and processing of the precursor for human mangano-superoxide dismutase. Biochim Biophys Acta 1989;994:30-36.

39. Heffner JE, Repine JE. Pulmonary strategies of antioxidant defense. Am Rev Respir Dis 1989; 140:531-554.

40. Bauman JW, Liu J, Liu YP, K!aassen CD. Increase in metallothionein produced by chemicals that induce oxidative stress. Tox Appl Pharmacol 1991:110:347-354.

41. Keyse SM, Applegate LA, Tromvoukis Y, Tyrrell RM. Oxidant stress lead to transcriptional activation of the human heme oxygenase gene in cultured skin fibroblasts. Mol Cell Biol 1990; 10:4967-4969. 
42. Keyse SM, Tyrrell RM. Heme oxygenase is the major 32-kDa stress protein induced in human skin fibroblasts by UVA radiation, hydrogen peroxide, and sodium arsenite. Proc Natl Acad Sci USA 1989;86:99-103.

43. Bast A, Goris RJA. Oxidative stress. Biochemistry and human disease. Pharmaceutisch Weekblad Scient 1989;11:199-206.

44. Cutler RG. Antioxidants in aging. Am J Clin Nutr 1991;53:373-379(S).

45. Ames BN. Endogenous oxidative DNA damage, aging, and cancer. Free Radic Res Commun 1989;7:121-128.

46. Cerutti PA. Response modification in carcinogenesis. Env Health Perspect 1989;81:3943.

47. Kensler TW, Trush MA. Role of oxygen radicals in tumor promotion. Environ Mutagen 1984;6:593-616.

48. Troll W, Wiesner R. The role of oxygen radicals as a possible mechanism of tumor promotion. Annu Rev Pharmacol Toxicol 1985;25:509-528.

49. Cerutti PA. Prooxidant states and tumor promotion. Science 1985;227:375-381.

50. Imlay JA, Linn S. DNA damage and oxygen radical toxicity. Science 1988;240:13021309.

51. Aruoma OI, Halliwell B, Gajewski E, Dizdaroglu M. Damage to the bases in DNA induced by hydrogen peroxide and ferric iron chelates. J Biol Chem 1989;264:20509. 20512.

52. Aruoma OI, Halliwell B, and Dizdaroglu M. Iron ion-dependent modification of bases in DNA by the superoxide radical-generating system hypoxanthine/xanthine oxidase. J Biol Chem 1989;264:13024-13028.

53. Tchou J, Kasai H, Shibutani S, Chung M-H, Laval J, Grollman AP, et al. 8-oxoguanine (8-hydroxyguanine) DNA glycosylase and its substrate specificity. Proc Natl Acad Sci $1991 ; 88: 4690-4694$.

54. Floyd RA. The role of 8-hydroxyguanine in carcinogenesis. Carcinogenesis 1990;11:1447-1450.

55. Marsh JP, Mossman BT. Role of asbestos and active oxygen species in activation and expression of omithine decarboxylase in hamster tracheal epithelial cells. Cancer Res 1991;51:167-173.

56. O'Brien TG. The induction of omithine decarboxylase as an early, possibly obligatory, event in mouse skin carcinogenesis. Cancer Res 1976;36:2644-2653.

57. Gilmour SK, Verma AK, Madara T, O'Brien TG. Regulation of ornithine decarboxylase gene expression in mouse epidermis and epidermal tumors during two-stage tumorigenesis. Cancer Res 1987;47:1221-1225.

58. Nishizuka Y. Studies and perspectives of protein kinase C. Science 1986;233:305-312.

59. Nakamura Y, Gindhart TD, Winterstein D, Tomita I, Seed JL, Colburn NH. Early superoxide dismutase-sensitive event promotes neoplastic transformation in mouse epidermal JB6 cells. Carcinogenesis 1988;9:203-207.

60. Lehmann AR. Xeroderma pigmentosum, Cockayne syndrome and ataxia-telangiectasia: disorders relating DNA repair to carcinogenesis. Cancer Surveys 1982;1:93-118.

61. Arlett CF, Lehman AR. Human disorders showing increased sensitivity to the induction of genetic damage. Ann Rev Genet 1978;12:95-115.

62. Topal MD. DNA repair, oncogenes and carcinogenesis. Carcinogenesis 1988;9:691696.

63. Ames BN. Oxygen radicals and human disease. Ann Intern Med 1987;107:526-545. 
64. Wallace SS. AP endonucleases and DNA glycosylases that recognize oxidative DNA damage. Env Mol Mutagen 1988;12:431-477.

65. Sancar A, Sancar GB. DNA repair enzymes. Ann Rev Biochem 1988;57:29-67.

66. Teebor GW, Boorstein RJ, Cadet J. The repairability of oxidative free radical mediated damage to DNA: a review. Int J Radiat Biol 1988;54:131-150.

67. Friedberg EC. DNA repair. New York; WH Freeman and Company, 1985.

68. Breimer LH. Repair of DNA damage induced by reactive oxygen species. Free Rad Res Comms 1991;14:159-171.

69. Van Houten B. Nucleotide excision repair in Eschericia coli. Microbiol Rev 1990;54:18-51.

70. Fornace Jr AJ, Zmudzka B, Hollander MC, Wilson SH. Induction of B-polymerase mRNA by DNA-damaging agents in Chinese Hamster Ovary cells. Mol Cell Biol 1989;9:851-853.

71. Fritz G, Tano K, Mitra S, Kaina B. Inducibility of the DNA repair gene encoding O-06 methylguanine-DNA methyltransferase in mammalian cells by DNA-damaging treatments. Mol Cell Biol 1991;11:4660-4668.

72. Schraufstatter IU, Hyslop PA, Hinshaw DB, Spragg RG, Sklar LA, Cochrane CG. Hydrogen peroxide-induced injury of cells and its prevention by inhibitors of poly(ADPribose) polymerase. Proc Natl Acad Sci USA 1986;83:4908-4912.

73. Harris AL. DNA repair: relationship to drug and radiation resistance, metastasis and growth factors. Int J Radiat Biol 1985;48:675-690.

74. Junod AF, Jomot L, Petersen $H$. Differential effects of hyperoxia and hydrogen peroxide on DNA damage, polyadenosine diphosphate-ribose polymerase activity, and nicotinamide adenine dinucleotide and adenosine triphosphate contents in cultured endothelial cells and fibroblasts. J Cell Physiol 1989;140:177-185.

75. Carson DA, Seto S, Wasson DB, Carrera CJ. DNA strand breaks, NAD metabolism and programmed cell death. Exp Cell Research 1986;164:273-281.

76. Horowitz S, Dafni N, Shapiro DL, Holm BA, Notter RH, Quible DJ. Hyperoxic exposure alters gene expression in the lung. J Biol Chem 1989;264:7092-7095.

77. Fornace Jr AJ, Alamo Jr. I, Hollander MC. DNA damage-inducible transcripts in mammalian cells. Proc Natl Acad Sci USA 1988;85:8800-8804.

78. Sambrook J, Fritsch EF and Maniatis T. Molecular Cloning: A Laboratory Manual, 2nd edition, Cold Spring Harbor; Cold Spring Harbor Laboratory Press, 1989.

79. Lambert ME, Ronai ZA, Weinstein IB, Garrels JI. Enhancement of major histocompatibility class 1 protein synthesis by DNA damage in cultured human fibroblasts and keratinocytes. Mol Cell Biol 1989;9:847-850

80. Cohen DS, Palmer E, Welch WJ, Sheppard D. The response of guinea pig airway epithelial cells and alveolar macrophages to environmental stress. Am J Respir Cell Mol Biol 1991:5:133-143.

81. Herrlich P, Angel P, Rahmsdorf HJ, Mallick U, Poting A, Hieber L, et al. The mammalian genetic stress response. Adv Enzyme Regul 1986;25:485-504.

82. Mai S, Stein B, van den Berg S, Kaina B, Lücke-Huhle C, Ponta H, et al., Mechanisms of the ultraviolet light response in mammalian cells. J Cell Science 1989;94:609-615.

83. DiGiuseppe JA, Hunting DJ, Dresler SL. Aphidicolin-sensitive DNA repair synthesis in human fibrob!asts damaged with bleomycin is distinct from UV-induced repair. Carcinogenesis 1990;11:1021-1026. 
84. Stein B, Rahmsdorf HJ, Steffen A, Litfin M, Herrlich P. UV-induced DNA damage is an intermediate step in UV-induced expression of human immunodeficiency virus type 1, collagenase, c-fos, and metallothionein. Mol Cell Biol 1989:9:5169-5181.

85. Lücke-Huhle C, Mai S, Herrlich P. UV-induced early-domain binding factor as the limiting component of simian virus 40 DNA amplification in rodent cells. Mol Cell Biol 1989;9:4812-4818.

86. Ronai ZA, Weinstein IB. Identification of ultraviolet-inducible proteins that bind to a TGACAACA sequence in the polyoma virus regulatory region. Cancer Res 1990;50:5374-5381.

87. Ronai ZA, Weinstein IB. Identification of a UV-induced trans-acting protein that stimulates polyomavirus DNA replication. J Virol 1988;62:1057-1060.

88. Hollander MC, Fornace Jr AJ. Induction of fos RNA by DNA-damaging agents Cancer Res 1989:49:1687-1692.

89. Ronai ZA, Okin E, Weinstein IB: Ultraviolet light induces the expression of oncogenes in rat fibroblast and human keratinocyte cells. Oncogene 1988;2:201-204.

90. Maltzman W, Czyzyk L. UV irradiation stimulates levels of p53 cellular tumor antigen in nontransformed mouse cells. Mol Cell Biol 1984;4:1689-1694.

91. Lane DP. P53, guardian of the genome. Nature 1992;358:15-16.

92. Fornace Jr AJ, Schalch H, Alamo Jr.I. Coordinate induction of metallothioneins I and II in rodent cells by UV irradiation. Mol Cell Biol 1988:8:4716-4720.

93. Angel P. Poting A, Mallick U, Rahmsdorf HJ, Schorpp M, Herrlich P. Induction of metallothionein and other mRNA species by carcinogens and tumor promoters in primary human skin fibroblasts. Mol Cell Biol 1986;6:1760-1766.

94. Fornace Jr AJ, Nebert DW, Hollander MC, Luethy JD, Papathanasiou M, Fargnoli J, et al. Mammalian genes coordinately regulated by growth arrest signals and DNA-damaging agents. Mol Cel Biol 1989;9:4196-4203.

95. Holbrook NJ, Luethy JD, Park JS, Fornace Jr. AJ, Fargnoli J. Molecular characterization of GADD153, a novel DNA-damage-inducible gene in mammalian cells. Free Rad Biol Med 1990;9:A46 (abstr).

96. Rosen CF, Gajic D, Jia Q. Drucker DJ. Ultraviolet B radiation induction of ornithine decarboxylase gene expression in mouse epidermis. Biochem J 1990;270:565-568.

97. Hillebrand GG, Winslow MS, Benzinger MJ, Heitmeyer DA, Bissett DL. Acute and chronic ultraviolet radiation induction of epidermal ornithine decarboxylase activity in hairless mice. Cancer Res 1990;50:1580-1584.

98. Rosen CF, Gajic D, Drucker DJ. Ultraviolet radiation induction of ornithine decarboxylase in rat keratinocytes. Cancer Res 1990;50:2631-2635.

99. Pegg AE. Polyamine metabolism and its importance in neoplastic growth and as a target for chemotherapy. Cancer Res 1988;48:759-774.

100. Ben-Ishai R, Sharon R, Rothman M, Miskin R. DNA repair and induction of plasminogen activator in human fetal cells treated with UV ultraviolet light. Carcinogenesis 1984;5:357-362.

101. Rotem N, Axelrod JH, Miskin R. Induction of urokinase-type plasminogen activator by UV light in human fetal fibroblasts is mediated through a UV-induced secreted protein. Mol Cel Biol 1987;7:622-631.

102. Tyrrell RM, Keyse SM. Inducible cellular defense against oxidative stress in cultured human cells. Free Rad Biol Med 1990;9:1 (abstr).

103. Freeman ML, Saunders EL, Meredith MJ. Stress response and glutathione. Free Rad Biol Med 1990;9:3 (abstr). 
104. Keyse SM, Tyrrell RM. Induction of the heme oxygenase gene in human skin fibroblasts. by hydrogen peroxide and UVA $(365 \mathrm{mn})$ radiation: evidence for the involvement of the hydroxyl radical. Carcinogenesis 1989;11:787-791.

105. Applegate LA, Luscher P, Tyrrell RM. Induction of heme oxygenase: a general response to oxidant stress in cultured mammalian cells. Cancer Res 1991;51:974-978.

106. Kupper TS, Chua AO, Flood P, McGuire J, Gubler U. Interleukin 1 gene expression in cultured human keratinocytes is augmented by ultraviolet radiation. J Clin Invest 1987;80:430-436.

107. Woloschak GE, Chang-Liu CM, Jones PS, Jones CA. Modulation of gene expression in Syrian hamster embryo cells following ionizing radiation. Cancer Res 1990;50:339-344.

108. Painter RB. Inhibition of mammalian cell DNA synthesis by ionizing radiation. Int J Radiat Biol 1986;49:771-781.

109. Lamb JR, Petit-Frère C, Broughton BC, Lehman AR, Green MHL. Inhibition of DNA replication by ionizing radiation is mediated by a trans-acting factor. Int J Radiat Biol 1989;56:125-130.

110. Singh SP, Lavin MF. DNA-binding protein activated by gamma radiation in human cells. Mol Cel Biol 1990; 10:5279-5285.

111. Munson GP, Woloschak GE. Differential effect of ionizing radiation on transcription in repair-deficient and repair-proficient mice. Cancer Res 1990;50:5045-5048.

112. Meier B, Radeke HH, Selle S, Younes M, Sies H, Resch K, et al. Human fibroblasts release reactive oxygen species in response to interleukin-1 or tumour necrosis factor- $\alpha$. Biochem J 1989;263:539-545.

113. Hallahan DE, Spriggs DR, Beckett MA, Kufe DW, Weichselbaum RR. Increased tumor necrosis factor $\alpha$ mRNA after cellular exposure to ionizing radiation. Proc Natl Acad Sci USA 1989;86:10104-10107.

114. Kelly J. Cytokines of the lung. Am Rev Respir Dis 1990;141:765-788.

115. Larrick JW, Wright SC. Cytotoxic mechanism of tumor necrosis factor-alpha. FASEB J 1990;4:3215-3223.

116. Vilcek J, Lee TH. Tumor necrosis factor. New insights into the molecular mechanisms of its multiple actions. J Biol Chem 1991;266:7313-7316.

117. Fiers W. Tumor necrosis factor. FEBS Letters 1991;285:199-212.

118. Wong GHW, Goedel DV. Induction of manganous superoxide dismutase by tumor necrosis factor: Possible protective mechanism. Science 1988;242:941-943.

119. Wong GHW, Elwell JH, Oterley LW, Goedel DV. Manganous superoxide dismutase is essential for cellular resistance to cytotoxicity of tumor necrosis factor. Cell 1989;58:923-931.

120. Masuda A, Longo D, Kobayashi Y, Appella E, Oppenheim JJ, Matsushima K. Induction of manganese superoxide dismutase by interleukin 1. FASEB J 1988;2:3087-3091.

121. Shaffer JB, Treanor CP, Del Vecchio PL. Expression of bovine and endothelial cell antioxidant enzymes following TNF- $\alpha$ exposure. Free Rad Biol Med 1990;8:497-502.

122. Visner GA, Dougall WC, Wilson JM, Burr IA, Nick HS. Regulation of manganese superoxide dismutase by lipopolysaccaride, interkeukin-1 and tumor necrosis factor. J Biol Chem 1990;265:2856-2864.

123. Schulze-Osthoff K, Bakker AC, Vanhaesebroeck B, Beyaer R, Jacob WA, Fiers W. Cytotoxic activity of tumor necrosis factor is mediated by early damage of mitochondrial functions. Evidence for the involvement of mitcchondrial radical generation. J Biol Chem 1992:267:5317-5323. 
124. yan Loon APGM, Pesold-Hurt B, Schatz G. A yeast mutant lacking mitochondrial manganese superoxide dismutase is hypersensitive to oxygen. Proc Natl Acad Sci USA 1986;83:3820-3824.

125. White CW, Ghezzi P, Dinarello CA, Caldwell SA, McMurtry IF, Repine JE. Recombinant tumor necrosis factor/cachectin and interleukin 1 pretreatment decreases lung oxidized glutathione accumulation, lung injury, and mortality in rats exposed to hyperoxia. J Clin Invest 1987;79:1868-1873.

126. White CW, Ghezzi P, McMahon S, Dinarello CA, Repine JE. Cytokines increase lung antioxidant enzymes during exposure to hyperoxia. J Appl Physiol 1989;66:1003-1007.

127. Angel P, Imagawa M, Chiu R, Stein B, Imbra RJ, Rahmsdorf HJ, et al. Phorbol ester-inducible genes contain a common cis element recognized by a TPA-modulated trans-acting factor. Cell 1987;49:729-739.

128. Nishizuka $\mathbf{Y}$. The role of protein kinase $\mathrm{C}$ in the cell surface signal-transduction and tumour promotion. Nature 1984;308:693-698.

129. Jonat C, Rahmsdorf HJ, Park KK, Cato ACB, Gebel S, Ponta H, et al. Antitumor promotion and antiinflammation: down-modulation of AP-1 (fos/jun) activity by glucocorticoid hormone. Cell 1990;62:1189-1204.

130. Lee W, Mitchell P, Tjian R. Purified transcription factor AP-1 interacts with TPA-inducible enhancer elements. Cell 1987;49:741-752.

131. Angel P, Baumann I, Stein B, Delius H, Rahmsdorf HJ, Herrlich P. 12-O-tetradecanoylphorbol-13-acetate induction of the human collagenase gene is mediated by an inducible enhancer element located in the 5'-flanking region. Mol Cell Biol 1987;7:2256-2266.

132. Bohm S, Berghard A, Pereswetoff-Morath C, Toftgard R. Isolation and characterization of complementary DNA clones corresponding to genes induced in mouse epidermis in vivo by tumor promoters. Cancer Res 1990;50:1626-1633.

133. Aggeler J, Murnane JP. Enhanced expression of procollagenase in ataxia-telangiectasia and xeroderma pigmentosum fibroblasts. In Vitro Cell Dev Biol 1990;26:915-922.

134. Cheng ERY, Mercier CE, Piedboeuf B, Johnston CJ, Watkins RH, Horowitz S. Cellspecific alterations in the expression of metallothionein mRNA during hyperoxic lung injury. Am Rev Respir Dis 1991;143:514 (abstr).

135. Horowitz S, Hall SB, Cheng ERY, Hyde RW, Johnston CJ, Mercier CE. Alterations in gene expression in fatty acid lung injury. Am Rev Respir Dis 1991;143:515 (abstr).

136. Iqbal J, Clerch LB, Hass MA, Frank L, Massaro D. Endotoxin increases lung $\mathrm{Cu}, \mathrm{Zn}$ superoxide dismutase mRNA: $\mathrm{O}_{2}$ raises enzyme synthesis. Am J Physiol 1989;257:6164.

137. Crapo JD, Tiemey DF. Superoxide dismutase and pulmonary oxygen toxicity. Am J Physiol 1974:226:1401-1407.

138. Frank L. Protection from $\mathrm{O}_{2}$ toxicity by preexposure to hypoxia: Lung antioxidant enzyme role. J Appl Physiol 1982;53:475-482.

139. Hart BA, Voss GW, Shatos MA, Doherty J. Cross-tolerance to hyperoxia following cadmium aerosol pretreatment. Tox Appl Pharmacol 1990;103:255-270.

140. Jackson RM, Frank L. Ozone-induced tolerance to hyperoxia in rats. Am Rev Respir Dis 1984;129:425-429.

141. White CW, Avraham KB, Shanley PF, Groner Y. Transgenic mice with expression of elevated levels of copper-zinc superoxide dismutase in the lungs are resistant to pulmonary oxygen toxicity. J Clin Invest 1991;87:2162-2168. 
142. Walther FFFJ, Kuipers IM, Pavlova Z, Willebrand D, Abuchowski A, Viau AT. Mitigation of pulmonary; oxygen toxicity in premature lambs with intravenous antioxidants. Exp Lung Res 1990;16:177-189.

143. Turrens JF, Crapo JD, Freeman BA. Protection against oxygen toxicity by intravenous injection of liposome-entrapped catalase and superoxide dimutase. J Clin Invest 1984;73:87-95.

144. Padmanabhan RV, Judapaty R, Lener IE, Schwartz BA, Moidal JR. Protection against pulmonary oxygen toxicity in rats by the intratracheal administration of liposome-encapsulated superoxide dismutase or catalase. Am Rev Respir Dis 1985;132:164-167.

145. Beckman JS, Minor RL, White CW, Repine JE, Rosen GM, Freeman BA. Superoxide, dismutase and catalase conjugated to polyethylene glycol increased endothelial enzyme. activity and oxidant resistance. J Biol Chem 1988;263:6884-6892.

146. Jornot L, Junod AF. Response of human endothelial cell antioxidant enzymes to hyperoxia. Am J Respir Cell Col Biol 1992;6:107-115.

147. Ho YS, Dey MS, Crapo JD. Modulation of lung antioxidant enzyme expression by hyperoxia. Am Rev Respir Dis 1990;141:821 (abstr).

148. Kinnula VL, Chang L, Everitt J, Crapo JD. Oxidants and antioxidants in alveolar epithelial type Il cells: in situ, freshly isolated, and cultured cells. Lung Cell Mol Physiol 1992;6:69-77.

149. Rahman IU, Clerch LB, Massaro D. Rat lung antioxidant enzyme induction by ozone. Am J Physiol 1991;260:412-418.

150. Mossman BT, Bignon J, Com M, Seaton A, Gee JBL. Asbestos: scientific developments and implications for public policy. Science 1990;247:294-301.

151. Mossman BT, Marsh JP. Evidence supporting a role for active oxygen species in asbestos-induced toxicity and lung disease. Env Health Perspect 1989;81:91-94.

152. Kamp DW, Graceffa B, Pryor WA, Weitzmann SA. The role of free radicals in asbestos induced diseases. Free Rad Biol Med 1992;12:293-315.

153. Mossman BT, Marsh JP. Role of active oxygen species in asbestos-induced cytotoxicity, cell proliferation, and carcinogenesis. In: Harris CC, Lechner JF and Brinkley BR, editors. Cellular and molecular aspects of fiber carcinogenesis. Cold Spring Harbor; Cold Spring Harbor Laboratory Press, 1991:159-168.

154. Eberhardt MK, Roman-Franco AA, Quiles MR. Asbestos-induced decomposition of hydrogen peroxide. Environ Res 1985;37:287-292.

155. Weitzman SA, Graceffa P. Asbestos catalyzes hydroxyl and superoxide radical generation from hydrogen peroxide. Arch Biochem Biophys 1984;228:373-376.

156. Zalma R, Bonneau L. Jaurand MC, Guignard J, Pezerat H. Formation of oxy-radicals by oxygen reduction arising from the surface activity of asbestos. Can J Chem 1987;65:2338-2341.

157. Dalal NS, Shi $X$, Vallyathan V. Potential role of silicon-oxygen radicals in acute lung injury. In: Mossman BT, Bégin RO, editors. Effects of Mineral Dusts on Cells. Berlin; Springer-Verlag, 1989:265-272.

158. Fubini B, Bolis V, Giamello E, Pugliese L, Volante M. The formation of oxygen reactive radicals at the surface of the crushed quartz dusts as a possible cause of silica pathogenicity. In: Mossman BT, Bégin RO, editors. Effects of Mineral Dusts on Cells.Berlin; Springer-Verlag, 1989:205-214.

159. Mossman BT, Marsh JP, Shatos MA. Alteration of superoxide dismutase activity in tracheal epithelial cells by asbestos and inhibition of cytotoxicity by antioxidants. Lab Invest 1986:54:204-212. 
160. Shatos MA, Doherty JM, Marsh JP and Mossman BT. Prevention of asbestos-induced. cell death in rat lung fibroblasts and alveolar macrophages by scavengers of active oxygen species. Environ Res 1987;44:103-116.

161. Voisin C, Aerts C, Wallaert B. Prevention of in vitro oxidant-mediated alveolar macrophage injury by cellular glutathione and precursors. Bull Eur Physiopathol Respir 1987;23:309-313.

162. Mossman BT, Marsh JP, Sesko A, Hill S, Shatos MA, Doherty J, et al. Inhibition of lung injury, inflammation, and interstitial pulmonary fibrosis by polyethylene glycol-conjugated catalase in rapid inhalation model of asbestosis. Am Rev Respir Dis 1990;141:1266-1271.

163. Janssen YMW, Marsh JP, Absher MP, Hemenway D, Vacek. PM, Leslie KO, et al. Expression of antioxidant enzymes in rat lungs after inhalation of asbestos or silica. J Biol Chem 1992;267:10625-10630.

164. Holley JA, Janssen YMW, Mossman BT, Taatjes D. Increased manganese superoxide dismutase protein in Type II epithelial cells of rat lungs after inhalation of crocidolite asbestos or cristobalite silica. Am J Path 1992;141:475-485.

165. Piguet PF, Collart MA, Grau GE, Sappino AP, Vassalli P. Requirement of tumour necrosis factor for the development of silica-induced pulmonary fibrosis. Nature 1990;344:245-247.

166. Driscoll KE, Strzelecki J, Hassenbein D, Janssen YMW, Marsh J, Oberdorster G, et al. Tumor necrosis factor (TNF): Evidence for the role of TNF in increased expression of manganese superoxide dismutase after inhalation of mineral dusts. Ann Occup Hyg (in press).

167. Janssen YMW, Marsh JP, Absher MP, Gabrielson E, Borm PJA, Mossman BT. Gene expression of heme oxygenase and antioxidant enzymes in human mesothelial cells and human adult lung fibroblasts after exposure to asbestos or active oxygen species. Am Rev Respir Dis 1992;145:713 (abstr).

168. Janssen YMW, Marsh JP, Borm PJA, Surinrut P, Haldeman K, Mossman BT. Asbestos-mediated gene expression in rat lung. In: Brown RC, Hoskins JA, Johnson NF, editors. Mechanisms in Fibre Carcinogenesis. New York; Plenum Press, 1991:359-365.

169. Heintz NH, Janssen YMW, Mossman BT. Persistent induction of c-fos and c-jun protooncogene expression by asbestos. Proc Natl Acad USA 1993;90:3299-3303.

170. Storz G, Tartaglia LA, Ames BN. Transcriptional regulator of oxidative stress-inducible genes: direct activation by oxidation. Science 1990;248:189-194.

171. Greenberg JT, Monach P, Chou JH, Josephy PD, Demple B. Positive control of a global antioxidant defense regulon activated by superoxide-generating agents in Escherichia coli. Proc Natl Acad Sci USA 1990;87:6181-6185.

172. Christman MF, Morgan RW, Jacobson FS, Ames BN. Positive control of a regulon for defenses against oxidative stress and some heat-shock proteins in Salmonella Typhimurium. Cell 1985;41:753-762.

173. Bowen SW, Hassan HM. Induction of the manganese-containing superoxide dismutase in Escherichia coli is independent of the oxidative stress (oxyR)-controlled regulon. J Biol Chem 1988;263:1480-1511.

174. Greenberg JT, Demple B. A global response induced in Escherichia coli by redox-cycling agents overlaps with that induced by peroxide stress. J Bacteriol 1989;171:39333939.

175. Lee PC, Bochner BR, Ames BN. AppppA, heat-shock stress, and cell oxidation. Proc Natl Acad Sci USA 1983:80:7496-7500. 
176. Bochner BR, Lee PC, Wilson SW, Cutler CW, Ames BN. AppppA and related adenylylated nucleotides are synthesized as a consequence of oxidation stress. Cell 1984;37:225-232.

177. Rushmore TH, King RG, Pauison KE, Picken C.B. Regulation of glutathione S-transferase subunit gene expression: identification of a unique xenobiotic-responsive element controlling inducible expression by planar aromatic compounds. Proc Natl Acad Sci USA 1990;87:3826-3830.

178. Rushmore TH, Pickett CB. Transcriptional regulation of the rat glutathione S-tranisferase Ya subunit gene. J Biol Chern 1990;265:14648-14653.

179. Favreau LV, Pickett CB. Transcriptional regulation of the rat NAD(P)H:quinone reductase gene. J Biol Chem 1991;266:4556-4561.

180. Rushmore TH, Morton MR, Picket CB. The antioxidant responsive element. Activation by oxidative stress and identification of the DNA consensus sequence required for functional activity. J Biol Chem 1991;266:11632-11639.

181. Matsui MS, Deleo VA. Induction of protein kinase $\mathrm{C}$ activity by ultraviolet radiation. Carcinogenesis 1990;11:229-234.

182. Perderiset M, Marsh JP, Mossman BT. Activation of protein kinase $\mathrm{C}$ by crocidolite asbestos in hamster tracheal epithelial cells. Carcinogenesis 1991:12:1499-1502.

183. Hallahan DE, Virudachalam S, Sherman ML, Huberman E, Kufe DW, Weichselbaum RR. Tumor necrosis factor gene expression is mediated by protein kinase $\mathrm{C}$ following activation by ionizing radiation. Cancer Res 1991;51:4565-4569.

184. Angel P, Karin M. The role of jun, fos and the AP-1 complex in cell proliferation and transformation. Biochim Biophys Acta 1991;1072:129-157.

185. Cerutti PA. Oxidant stress and carcinogenesis. Eur J Clin Invest 1991;21:1-5. BT. Asbestos-mediated gene expression in rat lung. In: Brown RC, Hoskins JA, Johnson NF, editors. Mechanisms in Fibre Carcinogenesis. NewYork; Plenum Press, 1991:359-365.

186. Amstad PA, Krupitza G, Cerutti PA. Mechanism of c-fos induction by active oxygen. Cancer Research 1992;52:3952-3960. 


\section{The Role of Active Oxygen Species in the Lung Toxicity Induced by Mineral Fibers and Particulates}

Yvonne M W Janssen, Paul J A Borm, Joanne P Marsh, and Brooke T Mossman.

Department of Pathology, University of Vermont, Burlington Vt, USA and the Department of Health Risk Analysis and Toxicology, University of Limburg, Maastricht, the Netherlands. 


\section{Introduction}

Inhalation of mineral fibers or particulates results in their deposition in lung tissue. The degree of penetration into the lung and the persistence of minerals depend in part on the physico-chemical characteristics of these particulates. For example, several types of asbestos fibers in the amphibole family (crocidolite), persist for a number of years in the lung whereas others, such as chrysotile asbestos fibers, are more degradable and disappear faster (Mossman et al., 1990a). The differences in persistence in the lung may be due to elements such as magnesium or silica which leach out of the fiber and result in dissociation.

Another important determinant affecting persistence of mineral fibers or particulates within the lung relates to the ability of macrophages to engulf these minerals during phagocytosis and their transport out of the lung via the bronchial tree or the lymphatic system (Kamp et al., 1992). Due to the fibrous structure of some minerals, phagocytosis is incomplete, causing the phenomenon of 'frustrated phagocytosis'. Figure 1 shows a macrophage attempting to engulf an asbestos fiber. At high concentrations of fibers, this results in death of the macrophage and renewed release of fibers into the lung. Moreover, at non-lethal concentrations of fibers, the macrophage can be chronically activated thus releasing a number of inflammatory mediators and active oxygen species (AOS) (Farber et al., 1990, Mossman and Marsh, 1989, Freeman and Crapo, 1982). The persistent accumulation of fibers in the lung, chronic activation of macrophages, and accumulation of infammatory cells cause local tissue damage. Aberrant repair of injury then results in collagen deposition leading to pulmonary fibrosis. The type and extent of fibrosis depends on the type of mineral inhaled and the site of its deposition within the lung (Mossman et al., 1990a). For example, nodular areas of fibrosis are observed following inhalation of silica particulates whereas a more diffuse pattern of fibrosis is caused by inhalation of asbestos fibers.

In addition to fibrosis, two forms of malignant disease, arising from different cell types are observed following exposure to asbestos. Bronchogenic carcinomas or lung cancer have been documented following occupational exposure to asbestos. Additive or synergistic relationships between cigarette smoking and asbestos exposure have been observed in workers (Mossman et al., 1990a). On the other hand, malignant mesothelioma, arising from the pleura of the lung is not associated with cigarette smoking. Evidence for development of lung cancer following exposure to other mineral dusts is more controversial. Experimental studies have demonstrated development of pulmonary malignancies in laboratory animals following exposure to silica dusts (Craighead, 1992). However, epidemiological studies have not strenghtened a cause and effect relationship between silica exposure and lung cancer in humans (Craighead, 1992, McDonald, 1989. Pairon et al., 1991). Studies examining the association be- 


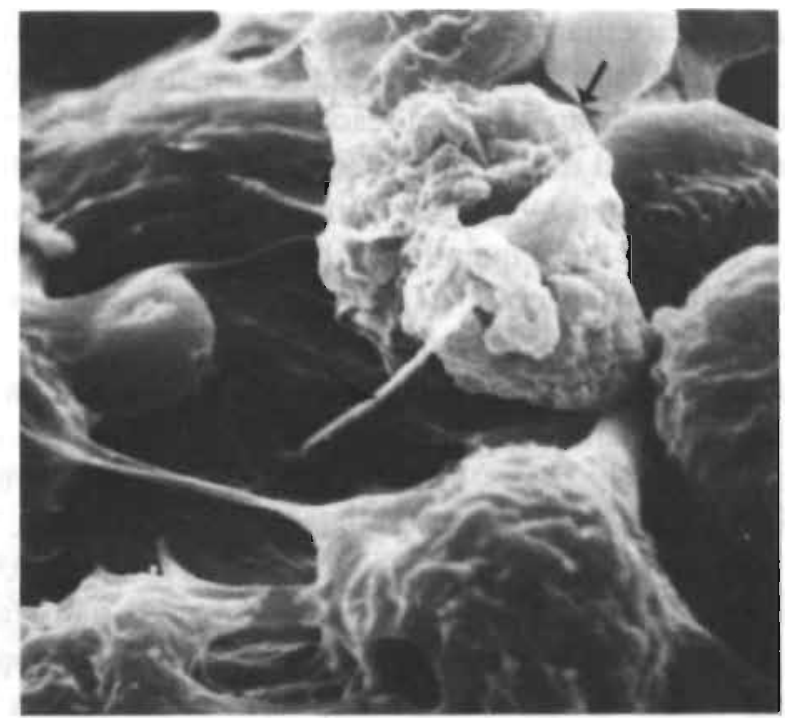

Figure 1 Macrophages in an airspace phagocytizing chrysotile asbestos fibers. Macrophages are indicated by arrows whereas arrowheads represent chrysotile asbestos fibers. Scanning electron microscopy.

tween exposure to mineral dusts and the development of lung cancer have been complicated by the finding that one particular mineral in many cases appears to be contaminated with other minerals. This increases the difficulty to relate exposure to one specific mineral with the etiology of specific disease. For example, amphibole asbestos fibers are sometimes found as contaminants of commercially mined minerals including chrysotile, talc and vermiculite (Mossman et al., 1990a).

\section{Physico-chemical Characteristics Of Minerals Related To AOS Formation}

Various investigators have shown that cell-free mineral preparations have the capability to generate AOS (Eberhardt et al., 1985, Weitzman and Graceffa, 1984, Dalal et al., 1989, Fubini et al., 1989). A number of techniques are available to measure AOS formation including electron spin resonance. The fact that many AOS are very reactive and consequently unstable neccesitates the use of chemical spin traps to generate a longer lived intermediate which can be identified by its specific resonance pattern. Using these techniques, is has been shown that different types of asbestos, including chrysotile, crocidolite and amosite asbestos can generate hydroxyl radical $\left(\mathrm{OH}^{\cdot}\right)$ in the presence of 
hydrogen peroxide (Eberhardt et al., 1985, Weitzman and Graceffa, 1984, Zalma et al., 1987). Transition metals present on many minerals, but most notably on crocidolite asbestos, drive a reaction known as the Fenton (modified Haber Weiss reaction) and results in $\mathrm{OH}$ formation. The importance of iron in this process is demonstrated by studies using the iron chelator, desferoxamine, which stabilizes iron and consequently inhibits the formation of $\mathrm{OH}$ (Kamp et al., 1992). The ability to generate AOS in an aqueous solution is a property which is not specific to asbestiform fibers, for some other mineral fibers including glass fibers have this ability as well (Gulumian and van Wyk, 1987). AOS production by minerals appears to be directly related to the amount of available iron present on the fibers. Fresh grinding or crushing of the fiber makes more iron available and consequently enhances $\mathrm{OH} \cdot$ formation. In addition to mineral fibers, a number of non-fibrous mineral dusts generate AOS in aqueous solutions. For instance, ESR-spectroscopy revealed that freshly ground anthracite coal generates AOS (Dalal et al., 1989b). Nickel or copper arsenides, present in metal mines or industrial sites, form AOS (Costa et al., 1989). Grinding of silica cleaves bonds in a silica tetrahydral lattice generating free radical sites on the surface of silica particles. ESR spectroscopy has shown formation of $\mathrm{SiO}$ and $\mathrm{Si}$ radicals from freshly ground silica and indicated $\mathrm{OH}$. formation upon reaction of silicon-based surface radicals with water (Dalal et al., 1989, Fubini et al., 1989, Castranova et al., 1989).

\section{Formation And Detoxification Of AOS By Cells}

In addition to the intrinsic ability of mineral dusts to generate AOS, these species are also formed as a consequence of encounter of target cells with mineral dusts. As mentioned above, during phagocytosis of fibers by pulmonary macrophages or polymorphonuclear leukocytes (PMN), a membrane bound NADPH-oxidase is activated and causes formation of a realm of AOS (Mossman et al., 1987, Mossman and Marsh, 1991). The pathway of AOS formation is shown in Figure 2. However, other processes activated within the cells can also cause AOS formation. For instance, release of the cytokine tumor necrosis factor (TNF) after exposure to mineral dusts, including asbestos and silica (Dubois et al., 1989), is also thought to cause oxidative stress (Larrick and Wright, 1990, Vilcek and Lee, 1991). Activation of the enzyme xanthine oxidase, observed after a number of stresses, is another source of AOS formation within cells (Friedl et al., 1989, Till et al., 1991).

Mammalian cells have an elaborate system of enzymatic and non-enzymatic antioxidants which scavenge AOS (Farber et al., 1990, Sun, 1990, Heffner and Repine, 1991). The functions of some antioxidant enzymes are outlined in figure 2. Mammalian cells contain 3 different superoxide dismutases (SOD) which 


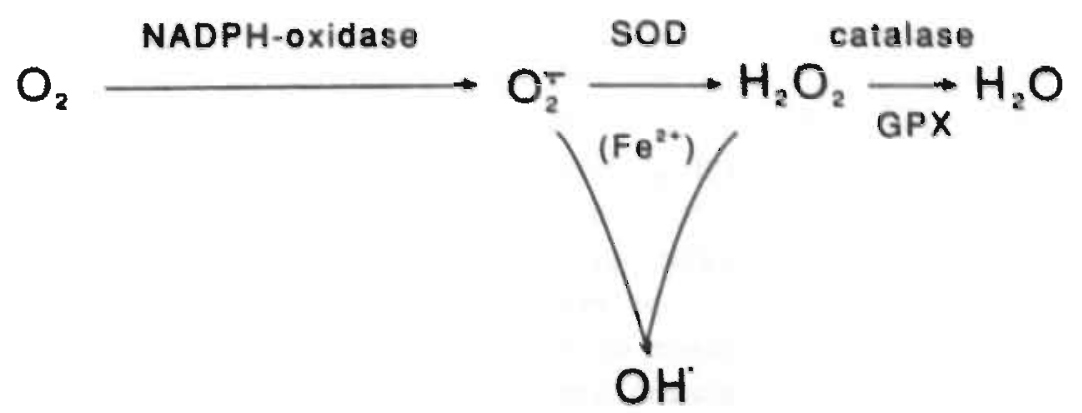

Figure 2 Formation and removal of active oxygen species. Activation of a membrane bound NADPH oxidase in phagocytes by mineral dusts causes formation of $\mathrm{O}_{2} \cdot \overline{\mathrm{O}_{2}}$ is converted to $\mathrm{H}_{2} \mathrm{O}_{2}$ by SOD. Subsequent action of catalase or GPX detoxifies $\mathrm{H}_{2} \mathrm{O}_{2}$ leading to formation of $\mathrm{H}_{2} \mathrm{O}, \mathrm{O}_{2}$, superoxide anion: $\mathrm{OH}$, hydroxyl radical; $\mathrm{H}_{2} \mathrm{O}_{2}$, hydrogen peroxide; $\mathrm{SOD}$. superoxide dismutase; GPX, glutathione peroxidase.

convert superoxide anion $\left(\overline{\mathrm{O}_{2}}\right)$ into $\mathrm{H}_{2} \mathrm{O}_{2}$, a non-radical intermediate. Two SODs contain $\mathrm{Cu}$ and $\mathrm{Zn}$; CuZnSOD, localized within peroxisomes (Keller et al., 1991) and extracellular superoxide dismutase (ECSOD) present in the extracellular milieu of cells (Marklund, 1984). The third form of SOD contains $\mathrm{Mn}$ (MnSOD) and is situated in mitochondria (Wispe et al., 1989). Both catalase and glutathione peroxidase (GPX) are enzymes converting $\mathrm{H}_{2} \mathrm{O}_{2}$ into $\mathrm{H}_{2} \mathrm{O}$. These enzymatic antioxidants are complemented by a number of non-enzymatic factors including glutathione, vitamins $\mathrm{C}$ and $\mathrm{E}$, albumin, ceruloplasmin and uric acid (Heffner and Repine, 1989). Normally, a balance exists between formation of AOS and antioxidant defenses. However, oxidant-induced damage might ensue after excessive production of oxidants or deficient functioning of the antioxidant system (Farber et al., 1990).

Our laboratory has been investigating responses of cells after exposure to various mineral dusts. We have focused on: i) production of AOS following exposure to mineral dusts; ii) alteration of antioxidant defenses following mineral exposure and; iii) implications of these processes in cell or tissue damage, proliferation, and carcinogenesis.

\section{Formation Of AOS After Exposure To Mineral Dusts}

A number of investigators have focused on generation of AOS following exposure of cells or tissues to mineral dusts. Approaches have been used in these studies include reduction of cytochrome $\mathrm{c}$ to measure $\mathrm{O}_{2}^{\overline{2}}$, phenol-red horseradish peroxidase to measure $\mathrm{H}_{2} \mathrm{O}_{2}$, and chemiluminescence techniques. 
Results of experiments measuring extracellular AOS formation by cells following exposure to mineral dusts have been summarized in a recent review (Kamp et al., 1992). A number of different cell types from human or animal origins have been used including alveolar macrophages (AM), peritoneal macrophages (PM), and PMN, to measure AOS production following in vitro exposure to mineral dusts. Some investigators have measured AOS formation in lavaged cells of healthy individuals exposed to mineral dusts, or in workers with occupational lung disease caused by exposure to minerals (Kamp et al., 1992). In some studies, AOS formation following mineral dust exposure could be correlated with cytotoxicity whereas in other cases this correlation was not evident.

The fibrous nature of asbestos is important in triggering $\overline{\mathrm{O}_{2}}$ release from inflammatory cells. We previously demonstrated that non-fibrous particles such as riebeckite, mordenite and glass are significantly less active in $\overline{\mathrm{O}_{2}}$ formation by $A M$ than the chemically identical fibers; crocidolite, erionite and code- 100 fiberglass, respectively (Hansen and Mossman, 1987).

Measurement of products of lipid peroxidation is another approach used by several laboratories to demonstrate involvement of AOS in mineral dust-induced toxicity. Lipid peroxidation has been demonstrated following mineral exposure in inflammatory cells, and whole lungs of laboratory animals (Kamp et al., 1992, Petruska et al., 1990). Measurement of products of lipid peroxidation in urine of workers exposed to asbestos or silica show increased levels of thiobarbituric acid- reactive material, indicating the involvement of AOS following occupational exposure to these minerals (Kamal et al., 1989).

Other studies addressing the involvement of AOS in mineral dust-induced cell or tissue damage have used scavengers of AOS. For example, our laboratory has demonstrated that cytotoxicity in rat lung fibroblasts, hamster tracheal epithelial (HTE) cells or AM induced by asbestos could be ameliorated or prevented by concomittant exposure to antioxidants (Mossman et al., 1986, Mossman and Marsh, 1989, Mossman and Marsh, 1991, Shatos et al., 1987). Similarly, silica-induced ce!l death was decreased by glutatione or glutathione precursors (Voisin et al., 1987). More importantly, systemic administration of polyethylene glycol-conjugated catalase in rats during inhalation of crocidolite asbestos reduced pulmonary inflammation, injury and fibrosis normally observed following asbestos inhalation (Mossman et al., 1990b).

\section{Alteration Of Antioxidant Defenses After Mineral Dust Exposure}

Following exposure to AOS, cells might alter their antioxidant defenses in order to prevent AOS mediated damage. We hypothesized that exposure to mineral dusts causing formation of $\mathrm{AOS}$ gives rise to alterations in antioxidant enzymes. 
In order to address this hypothesis we examined antioxidant enzymes in vitro using different target cells of mineral dust-induced disease, in rat lungs, and in workers exposed to mineral dusts.

One technique being used in our laboratory to study regulation of antioxidant enzymes following exposure to AOS or mineral dusts is Northern blot analysis to determine gene expression of different antioxidant enzymes. In this technique, total RNA is extracted from cells or lung tissue, electrophoresed and transferred onto nitrocellulose filters and hybridized with [ $\left.{ }^{32} \mathrm{P}\right]$-labeled cDNA probes encoding antioxidant enzyme genes (Sambrook et al., 1989). With this technique we demonstrated differential gene regulation of antioxidant enzymes in HTE cells following exposure to $\mathrm{H}_{2} \mathrm{O}_{2}$ or the AOS-generating system xanthine plus xanthine oxidase $(\mathrm{X} / \mathrm{XO}) . \mathrm{X} / \mathrm{XO}$ treatment of cells lead to increased gene expression of MnSOD, whereas exposure of cells to $\mathrm{H}_{2} \mathrm{O}_{2}$ caused increases in mRNA levels of catalase, and increased expression of glutathione peroxidase and MnSOD to a lesser extent (Shull et al., 1991).

In recent studies, we examined oxidant stress responses in human adult lung fibroblasts (HAL) and human pleural mesothelial cells (HMC) following exposure to asbestos or X/XO (Janssen et al., 1992a). Results of these studies show that $\mathrm{HMC}$ respond to asbestos or $\mathrm{X} / \mathrm{XO}$ with increases in mRNA levels of $\mathrm{MnSOD}$. In addition, $\mathrm{X} / \mathrm{XO}$ or asbestos caused increased gene expression of heme oxygenase (HO)(Janssen et al., 1992a), an enzyme induced in mammalian cells following oxidative stress and implicated in cell defense against AOS (Applegate et al., 1991, Keyse and Tyrrell., 1989). In HAL cells crocidolite asbestos caused increases in mRNA levels of HO whereas MnSOD gene expression remained unaltered (Janssen et al., 1992a). Figure 3 shows mRNA levels of MnSOD and $\mathrm{HO}$ in HMC cells following exposure to crocidolite asbestos or $\mathrm{X} / \mathrm{XO}$. Crocidolite or $\mathrm{X} / \mathrm{XO}$ cause increased in gene expression of MnSOD and $\mathrm{HO}$ in HMC cells whereas addition of polystyrene beads, a negative particulate control, failed to alter mRNA levels of these enzymes. HMC cells are more sensitive to the cytotoxic effects of asbestos or X/XO in comparison to HAL cells. These initial studies suggest that HMC cells are not compromised in their ability to increase antioxidant defenses following exposure to AOS or mineral dusts.

In addition, we investigated antioxidant enzymes in rat lung after inhalation of crocidolite asbestos or cristobalite silica (Janssen et al., 1992b). In crocidolite-exposed rat lungs we observed increased gene expression of MnSOD, GPX, and catalase, increased MnSOD protein levels and increased enzyme activities of total SOD, catalase and GPX. In contrast, cristobalite caused striking increases in MnSOD mRNA and protein levels whereas gene expression of other antioxidant enzymes remained unaltered. In addition, no alterations in activities of SOD, catalase or GPX were observed. These results indicate distinct mechanisms of regulation of antioxidant enzymes following inhalation 


\section{MnSOD}

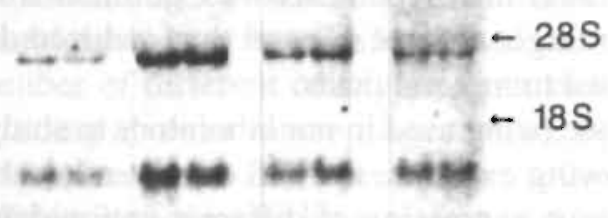

HO

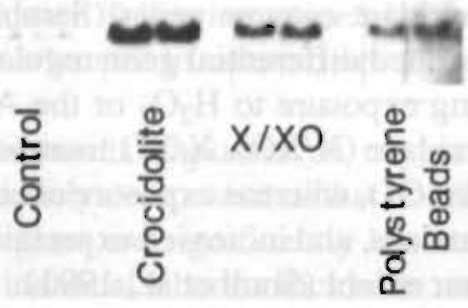

Figure 3 Northern blot of $\mathrm{MnSOD}$ and heme oxygenase (HO) in $\mathrm{HMC}$ cells following exposire to crocidolite asbestos or xanthine plus xanthine oxidase. Confluent HMC cells were treated with Union Internationale Contre Le Cancer reference crocidolite asbestos (1.9 $\left.\mathrm{ug} / \mathrm{cm}^{2}\right)$, xanthine plus xanthine oxidase (X/XO), a generating system of AOS, $0.1 \mathrm{Uiml}$, Calbiochem, La Jolla, CA ), or polystyrene beads (10 ug/ $\mathrm{cm}^{2}$, Polysciences, Warrington, PA). After 24 hours of exposure, RNA was extracted, electrophoresed, and transferred onto nitrocellulose filters (Sambrook et al. 1989). Blots were hybridized with CDNA probes encoding MnSOD or heme oxygenase, as described elsewhere (Applegate et al. 1991, Janssen et al. $1992 \mathrm{~b}$ ). $28 \mathrm{~S}$ and 185 ribosomal RNA species are indicated by arrows. Note the multiple mRNA species for MnSOD (Shull et al. 1991).

\section{MnSOD}

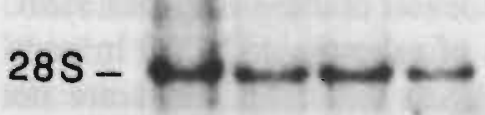

$18 \mathrm{~S}-$
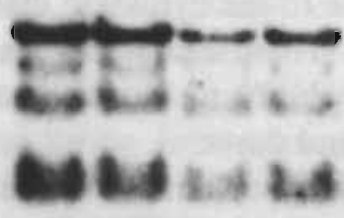

Crocidolite

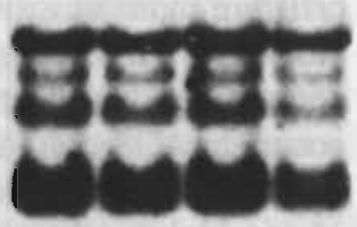

Cristobalite

Figure 4 Northern blot of MnSOD in rat lung after 9 days of inhalation of crocidolite asbestos or cristobalite silica. Rats were exposed to $7-10 \mathrm{mg} / \mathrm{m}^{3}$ air of crocidolite or cristobalite. RNA was processed as described in Figure 3. Increases in MnSOD mRNA levels are apparent after inhalation of either mineral. 
of crocidolite or cristobalite (Janssen et al., 1992b). Figure 4 shows MnSOD mRNA levels in rat lung after 9 days of inhalation of crocidolite asbestos or cristobalite silica, a timepoint where we observe increased gene expression of MnSOD. Both minerals caused increases in MnSOD mRNA levels in lung, although more striking increases were observed following cristobalite exposure. Using immunocytochemistry, we showed that MnSOD protein was localized predominantly in mitochondria of type II pneumocytes. Quantitative increases in MnSOD protein were apparent in type II cells following inhalation of crocidolite or cristobalite, which correlated with overall increases in MnSOD immunoreactive protein in whole lung (Holley et al., 1992).

Several investigators have demonstrated induction of MnSOD gene expression after exposure to bacterial endotoxin (LPS), tumor necrosis factor (TNF) or interleukin 1 (L-1)(Wong and Goedel, 1988, Masuda et al., 1988, Shaffer et al., 1990). TNF and IL-1 are released by inflammatory cells after in vitro exposure to asbestos or silica (Dubois et al., 1989, Driscoll et al., 1989). Therefore, TNF could mediate increases in gene expression and protein levels of MnSOD that we observe in rats following exposure to asbestos or silica (Driscoll et al., 1992).

Studies examining workers exposed to silica-containing dusts including coal mine dust, have revealed alterations of antioxidant defenses in peripheral blood. For example, activities of some antioxidant enzymes were correlated in red blood cells of coal workers with radiological abnormalities, but not in control workers. Furthermore glutatione levels were decreased in individuals with early stages of coal workers' pneumoconiosis, but were increased in patients with progressive massive fibrosis (Borm et al., 1986, Engelen et al., 1990).

In summary, these studies reveal specific alterations of some components of the antioxidant defense system following exposure to mineral dusts in vitro in isolated cell systems, in rat lungs, and in workers exposed to mineral dusts. Increases in antioxidants could reflect an adaptation to mineral dust-induced oxidant stress. However, in our rapid onset inhalation models of asbestosis, rats develop acute pulmonary damage and a diffuse fibrosis subsequently, despite increases in antioxidant defenses. This might indicate that increases in antioxidant defenses are insufficient to protect the rats from disease, at the high airborne concentrations of minerals applied in our model $\left(7-10 \mathrm{mg} / \mathrm{m}^{3}\right.$ air $)$ and generally used by others.

\section{Involvement Of Aos In Proliferation Induced By Asbestos}

In addition to altering antioxidant defenses, mineral dusts cause proliferative alterations in pulmonary target cells of asbestos-induced disease. Our laboratory has focused on omithine decarboxylase (ODC), a rate limiting enzyme in polyamine synthesis which is essential for cell division (Gilmour et al., 1987, 
O'Brien, 1976). Tumor promotors will induce ODC enzyme activity, and therefore ODC enzyme induction may be linked to tumor promotion (Marsh and Mossman, 1991). Initial studies showed that the fibrous nature of asbestos fibers is critical in augmenting ODC activity in HTE cells (Marsh and Mossman, 1988). In addition to asbestos, glass fibers were also potent inducers of ODC activity. Exposure of HTE cells to X/XO also caused increases in ODC mRNA and enzyme activity, showing that AOS have the ability to induce ODC (Marsh and Mossman, 1991). Recent studies showed that antioxidant enzymes could diminish asbestos-induced ODC mRNA levels and enzyme activity, indicating that AOS mediate ODC induction by asbestos (Marsh and Mossman, 1991). Figure 5 shows a Northern blot of ODC mRNA levels in rat lung following 9 days of inhalation of asbestos or silica. Inhalation of either mineral results in increased mRNA levels of ODC in lung. These findings indicate that proliferative changes occur in lung following inhalation of these mineral dusts presumably by oxidant-dependent mechanisms.

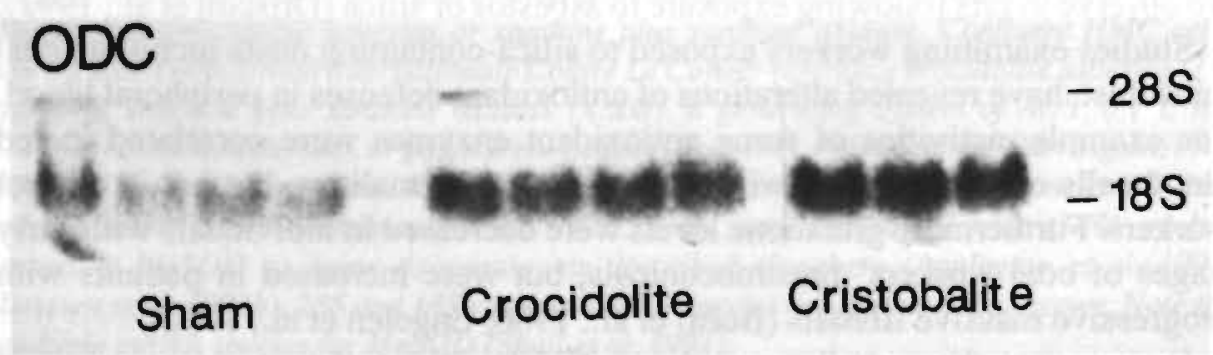

Figure 5 Northern blot of $O D C$ in rat lung after 9 days of inhalation of crocidolite asbestos or cristobalite silica, both at $7-10 \mathrm{mg} / \mathrm{m}^{3}$ air. Inhalation of crocidolite or cristohalite causes increases in ODC mRNA levels in rat lung

\section{Summary And Conclusions}

A causal role of AOS in the etiology of asbestos-induced lung disease has been demonstrated by our laboratory (Mossman and Marsh, 1989, Shatos et al., 1987, Mossman et al., 1990b). AOS are generated by acellular mechanisms, driven by transition metals on the fibers, and by inflammatory cells following phagocytosis of fibers within the lung. AOS cause a multitude of effects. They damage a number of macromolecules, including proteins, lipids, and DNA. In addition, they alter genetic processes affecting expression of genes with differing functions. We have shown that gene expression of antioxidant enzymes is augmented following exposure to mineral dusts, including asbestos and silica in rat lung, as 
well as in HMC cells in vitro following exposure to asbestos. These increases in antioxidant defenses can be regarded as a reaction to mineral dust-induced oxidative stress which might lead to adaptation to subsequent oxidative injury.

Aside from their ability to induce antioxidant defenses, mineral dusts at low doses also have proliferative effects in cells in vitro and in whole lung. We have shown that ODC, an enzyme intrinsic to cell proliferation, is increased in rat lung following inhalation of asbestos or silica, and in vitro in HTE cells after exposure to asbestos. Evidence for the involvement of AOS in these responses was obtained from studies in our laboratory showing that antioxidants could ameliorate increases in ODC gene expression and activity induced by asbestos in HTE cells (Marsh and Mossman, 1991). The balance between increases in antioxidant defenses versus increases in proliferation could be an important determinant of the effects of certain mineral dusts on the lung and the development of disease.

Clearly, AOS are not the only factors mediating pulmonary effects of mineral dusts, but part of a cascade of processes triggered within the lung following inhalation of minerals. A number of cytokines or growth factors are generated in the lung along with AOS following mineral deposition, some of which have profound effects on disease processes elicited in the lung (Mossman et al., 1990a, Piquet et al., 1990). However our laboratory has focused on AOS as "second messengers" of asbestos-induced toxicity and has demonstrated both in vitro and in vivo that these species are critical to the development of asbestosinduced pulmonary damage, fibrosis, and cell proliferation driven by asbestos fibers (Mossman and Marsh, 1991). More studies are needed to acertain the role of AOS in pulmonary effects caused by other mineral dusts. 


\section{REFERENCES}

Applegate, L.A., Luscher, P., Tyrrell, R.M. (1991) "Induction of heme oxygenase: a general response to oxidant stress in cultured mammalian cells." Cancer Res., 51, 974-978.

Borm, P.J.A., Bast, A., Wouters, E.F.M., Slangen, J.J.M., Swaen, G.M.H., Boorder de, Tj. (1986) "Red blood cell anti-oxidant parameters in silicosis." Int. Arch. Occup. Environ. Health, 58, 235-244.

Castranova, V., Vallyathan, V., Van Dyke, K., Dalal, N.S. (1989). "Use of chemiluminescence assays to monitor the surface characteristics and biological reactivity of freshly fractured vs aged silica." In B.T. Mossman, R.O. Begin, Eds., Effects of Mineral Dusts on Cells, Springer-Verlag, Berlin, pp 181-188.

Costa, D., Guignard, J., Pezerat, H. (1989a). "Production of free radicals arising firom the surface activity of minerals and oxygen. Part II. Arsenides, sulfides, and sulfoarsenides of iron, nickel and copper." Toxicol. Indust. Health, 5, 1079-1097.

Costa, D., Guignard, J., Pezerat, H. (1989b). "Production of free radicals by non-fibrous materials in a cell-free buffer medium." In B.T. Mossman, R.O. Begin, Eds., Effects of Mineral Dusts on Cells, Springer-Verlag, Berlin, pp 189-196.

Craighead, J.E. (1992). "Do silica and asbestos cause lung cancer." Arch. Pathol. Lab. Med., 116, 16-20.

Dalal, N.S., Shi, X., Vallyathan, V. (1989a). "Potential role of silicon-oxygen radicals in acute lung injury." In B.T. Mossman, R.O. Bégin, Eds., Effects of Mineral Dusts on Cells, Springer-Verlag, Berlin, pp. 265-272.

Dalal, N.S., Suryan, M.M., Vallyathan, V., Green, F.H.Y., Jafari, B., Wheeler, R. (1989b). "Detection of reactive free radicals in fresh coal mine dust and their implication for pulmonary injury." Ann. Occup. Hyg., 33, 79-84.

Driscoll, K.E., Lindenschmidt, R.C., Maurer, J.K., Higgins, J.M. (1989) "Release of interleukin- 1 and tumor necrosis factor by rat alveolar macrophages after in vivo and in vitro exposure to mineral dusts." In B.T. Mossman, R.O. Begin, Eds., Effects of Mineral Dusts on Cells, Springer-Verlag, Berlin, pp. 101-108.

Driscoll, K.E., Strzelecki, J., Hassenbein, D., Janssen, Y.M.W., Marsh, J., Oberdorster, G., Mossman, B.T. (1992) "Tumor necrosis factor (TNF): Evidence for the role of TNF in increased expression of manganese superoxide dismutase after inhalation of mineral dusts." Ann. Occup. Hyg., in press.

Dubois, C.M., Bissonnette, E., Rola-Pleszczynski, M. (1989) "Asbestos fibers and silica particles stimulate rat alveolar macrophages to release tumor necrosis factor: autoregulatory role of leukotriene B4." Am. Rev. Respir. Dis., 139, 1257-1264

Eberhardt, M.K., Roman-Franco, A.A., Quiles, M.R. (1985)."Asbestos-induced decomposition of hydrogen peroxide." Environ. Res., 37, 287-292.

Engelen, J.J., Borm, P.J., Sprundel, van M., Leenaerts, L. (1990) "Blood anti-oxidant parameters at different stages of pneumoconiosis in coal workers." Environ. Health Perspect., 84, 165-172.

Farber, J.L., Kyle, M.E., Coleman, J.B. (1990). "Biology of Disease. Mechanisms of cell injury by activated oxygen species." Lab. Invest., 62, 670-679.

Freeman, B.A., Crapo, J.D. (1982). "Biology of Disease. Free radicals and tissue injury." Lab. Invest., 47: 412-426.

Friedl, H.P., Till, G.O., Ryan, U.S., Ward, P.A. (1989) "Mediator-induced activation of xanthine oxidase in endothelial cells." FASEB J., 3, 2512-2518. 
Fubini, B., Bolis, V., Giamello, E., Pugliese, L., Volante, M. (1989). "The formation of oxygen reactive radicals at the surface of the crushed quartz dusts as a possible cause of silica pathogenicity." In B.T. Mossman, R.O. Bégin, Eds., Effects of Mineral Dusts on Cells, Springer-Verlag, Berlin, pp. 205-214.

Gilmour, S.K. Verma, A.K., Madara, T., O'Brien, T.G. (1987) "Regulation of omithine decarboxylase gene expression in mouse epidermis and epidermal tumors during twostage tumorigenesis." Cancer Res., 47, 1221-1225.

Gulumian, M., van Wyk, J.A. (1987). "Hydroxyl radical production in the presence of fibres by a fenton-type reaction." Chem-Biol. Interactions, 62, 89-97.

Hansen, K. Mossman, B.T. (1987) "The generation of superoxide from alveolar macrophages exposed to asbestiform and non-fibrous particles." Cancer Res.,47, 1681-1686.

Heffner, J.E., Repine, J.E. (1989) "Pulmonary strategies of antioxidant defense." Am. Rev. Respir. Dis., 140, 531-554.

Heffner, J.E., Repine, J.E. (1991) "Antioxidants and the lung." In R.G. Chrystal, J.B. West, P.J. Barnes, N.S. Chemlack, E.R. Weibel, Eds., The Lung: Scientific Foundations, Raven Press, New York, p 1811.

Holley, J.A., Janssen, Y.M.W., Mossman, B.T., Taatjes, D. (1992) "Increased manganese superoxide dismutase protein in Type II epithelial cells of rat lungs after inhalation of crocidolite asbestos or cristobalite silica." Am. J. Path., 141, 475-485.

Janssen, Y.M.W., Marsh, J.P., A.bsher, M.P., Gabrielson, E., Borm, P.J.A., Mossman, B.T. (1992a) "Gene expression of heme oxygenase and antioxidant enzymes in human mesothelial cells and human adult lung fibroblasts after exposure to asbestos or active oxygen species.” Am. Rev. Respir. Dis., 145, 713 (abstr).

Janssen, Y.M.W., Marsh, J.P., Absher, M.P., Hemenway, D., Vacek, P.M., Leslie, K.O., Borm, P.J.A., Mossman, B.T. (1992b) "Expression of antioxidant enzymes in rat lungs after inhalation of asbestos or silica." J. Biol. Chem., 267, 10625-10630.

Kamal, A.A.M., Gomaa, A., Khafif, M.E., Hammad, A.S. (1989) “ Plasma lipid peroxides among workers exposed to silica or asbestos dusts." Environ. Res., 49, 173-180.

Kamp, D.W., Graceffa, B., Pryor, W.A., Weitzmann, S.A.(1992). " The role of free radicals in asbestos induced diseases." Free Rad. Biol. Med., 12, 293-315.

Keller, G.A., Warner, T.G., Steimer, K.S., Hallewell, R.A. (1991) "Cu,Zn superoxide dismutase is a peroxisomal enzyme in human fibroblasts and hepatoma cells." Proc. Natl. Acad. Sci. U.S.A., 88, 7381-7385.

Keyse, S.M., Tyrrell, R.M. (1989) "Heme oxygenase is the major 32-kDa stress protein induced in human skin fibroblasts by UVA radiation, hydrogen peroxide, and sodium arsenite." Proc. Natl. Acad. Sci. U.S.A., 86, 99-103.

Larrick, J.W., Wright, S.C. (1990) "Cytotoxic mechanism of tumor necrosis factor-alpha." FASEB J., 4, 3215-3223.

Marklund, S.L. (1984) "Extracellular superoxide dismutase and other superoxide dismutase isoenzymes in tissues from nine mammalian species." Biochem. J., 222, 649-655.

Marsh, J.P., Mossman, B.T. (1988) "Mechanisms of induction of ornithine decarboxylase activity in tracheal epithelial cells by asbestiform fibers." Cancer Res., 48, 709-714.

Marsh, J.P., Mossman, B.T. (1991) "Role of asbestos and active oxygen species in activation and expression of ornithine decarboxylase in hamster tracheal epithelial cells." Cancer Res., 51, 167-173.

Masuda, A., Longo, D., Kobayashi, Y., Appella, E., Oppenheim, J.J., Matsushima, K. (1988) "Induction of manganese superoxide dismutase by interleukin 1." FASEB J., 2, 30873091. 
McDonald, J.C. (1989)."Silica, silicosis and lung cancer." Br. J. Indust. Med., 46, 289-291.

Mossman, B.T., Marsh, J.P., Shatos, M.A. (1986) "Alteration of superoxide dismutase activity in tracheal epithelial cells by asbestos and inhibition of cytotoxicity by antioxidants." Lab. Invest., 54, 204-212.

Mossman, B.T., Marsh, J.P., Shatos, M.A., Doherty, J., Gilbert, R., Hill, S. (1987)."Implication of active oxygen species as second messengers of asbestos toxicity." Drug Chem. Toxicol., 10, 157-180.

Mossman, B.T., Marsh, J.P. (1989)."Evidence supporting a role for active oxygen species in asbestos-induced toxicity and lung disease." Env. Health Perspect., 81, 91-94.

Mossman, B.T., Bignon, J., Com, M., Seaton, A., Gee, J.B.L. (1990a),"Asbestos: scientific developments and implications for public policy." Science, 247, 294-301.

Mossman, B.T., Marsh, J.P., Sesko, A., Hill, S., Shatos, M.A., Doherty, J., Petruska,J., Adler, K.B., Hernenway, D., Mickey R., Vacek, P., Kagan, E. (1990b) "Inhibition of lung injury, inflammation, and interstitial pulmonary fibrosis by polyethylene glycol-conjugated catalase in a rapid inhalation model of asbestosis." Am. Rev. Respir. Dis., 141, 1266-1271.

Mossman, B.T., Marsh, J.P. (1991) "Role of active oxygen species in asbestos-induced cytotoxicity, cell proliferation, and carcinogenesis." in C.C. Harris, J.F. Lechner, B.R. Brinkley, Eds., Cellular and Molecular Aspects of Fiber Carcinogenesis, Cold Spring Harbor Laboratory Press, Cold Spring Harbor, pp 159-168.

O'Brien, T.G. (1976) "The induction of omithine decarboxylase as an early, possibly oblieatory, event in mouse skin carcinngenecie " Cancer Reac, 36, 2k44.2653

Pairon, J.C., Brochard, P., Jaurand, M.C., Bignon, J. (1991)."Silica and lung cancer: a controversial issue." Eur. Respir. J., 4, 730-744.

Petruska, J.M., Marsh, J., Bergeron, M., Mossman, B.T. (1990) "Brief inhalation of asbestos compromises superoxide production in cells from bronchoalveolar lavage." Am. J. Respir. Cell Mol. Biol., 2, 129-136.

Petruska, J.M., Wong, S.H.Y., Sunderman, Jr. F.W, Mossman, B.T. (1990) "Detection of lipid peroxidation in lung and in bronchoalveolar lavage cells and fluid." Free Rad. Biol. Med., 9, 51-58.

Piguet, P.F., Collart, M.A., Grau, G.E., Sappino, A.P., Vassalli, P. (1990) "Requirement of tumour necrosis factor for the development of silica-induced pulmonary fibrosis." Nature, $344,245-247$.

Sambrook, J., Fritsch, E.F., Maniatis, T. (1989). Molecular Cloning: A Laboratory Manual. Cold Spring Harbor Laboratory Press, Cold Spring Harbor.

Shaffer, J.B., Treanor, C.P., Del Vecchio, P.L. (1990) "Expression of bovine and endothelial cell antioxidant enzymes following TNF- $\alpha$ exposure." Free Rad. Biol. Med., 8, 497-502.

Shatos, M.A., Doherty, J.M., Marsh, J.P., Mossman, B.T. (1987) "Prevention of asbestos-induced cell death in rat lung fibroblasts and alveolar macrophages by scavengers of active oxygen species." Environ. Res., 44, 103-116.

Shull, S., Heintz, N.H., Periasamy, M., Manohar, M., Janssen, Y.M.W., Marsh, J.P., Mossman, B.T. (1991) "Differential regulation of antioxidant enzymes in response to oxidants." J. Biol. Chem., 266, 24398-24403.

Sun, Y. (1990) "Free radicals, antioxidant enzymes, and carcinogenesis." Free Rad. Biol. Med., 8, 583-599.

Till, G.O., Friedl, H.P., Ward, P.A. (1991) "Lung injury and complement activation: Role of neutrophils and xanthine oxidase." Free Rad. Biol. Med., 10, 379-386.

Vilcek, J., Lee, T.H. (1991) "Tumor necrosis factor. New insights into the molecular mechanisms of its multiple actions." J. Biol. Chem., 266, 7313-7316. 
Voisin, C., A.erts, C., Wallaert, B. (1987) "Prevention of in vitro oxidant-mediated alveolar macrophage injury by cellular glutathione and precursors." Bull. Eur. Physiopathol. Respir., 23, 309-313.

Weitzman, S.A., Graceffa, P. (1984)."Asbestos catalyzes hydroxyl and superoxide radical generation from hydrogen peroxide." Arch. Biochem. Biophys., 228, 373-376.

Wispé, J.R., Clark, J.C., Burhans, M.S., Kropp, P.E., Korfhagen, T.R., Whitsett, J.A. (1989) "Synthesis and processing of the precursor for human mangano-superoxide dismutase." Biochim. Biophys. Acta., 994, 30-36.

Wong, G.H.W., Goedel, D.V. (1988) "Induction of manganous superoxide dismutase by tumor necrosis factor: Possible protective mechanism." Science, 242, 941-943.

Zalma, R., Bonneau, L., Jaurand, M.C., Guignard, J., Pezerat, H. (1987)."Formation of oxy-radicals by oxygen reduction arising from the surface activity of asbestos." Can. J. Chem., 65, 2338-2341.

\section{Acknowledgements}

The authors thank Judith Kessler for providing the illustrations. This work was supported by grants from NIH (RO1) and the EPA to B. T. Mossman. 


\section{Expression of Antioxidant Enzymes in Rat Lungs after Inhalation of Asbestos or Silica}

Yvonne M. W. Janssen, Joanne P. Marsh*, Marlene P. Absher†, David Hemenway ${ }^{\ddagger}$, Pamela M Vacek ${ }^{\S}$, Kevin O. Leslie*, Paul J. A. Borm, and Brooke T. Mossman*

Department of Occupational and Environmental Health \& Toxicology University of Limburg, P. O. Box 616, 6200 MD Maastricht, The Netherlands Departments of Pathology*, Medicine ${ }^{\dagger}$, Civil and Mechanical Engineering $\ddagger$, and Medical Biostatistics ${ }^{\S}$, University of Vermont College of Medicine, Burlington, Vermont 05405 


\section{Summary}

Several studies indicate that active oxygen species (AOS) play an important role in the development of pulmonary disease (asbestosis and silicosis) after exposure to mineral dusts. The present study was conducted to determine if inhaled fibrogenic minerals induced changes in gene expression and activities of antioxidant enzymes (AOE) in rat lung. Two different fibrogenic minerals were compared, crocidolite, an amphibole asbestos fiber, and cristobalite, a crystalline silicon dioxide particle. Steady-state mRNA levels, immunoreactive protein and activities of selected $A O E$ were measured in lungs 1-10 days after initiation of exposure and at 14 days after cessation of a 10 day exposure period. Exposure to asbestos resulted in significant increases in steady- state mRNA levels of manganese- containing superoxide dismutase (MnSOD) at 3 and 9 days and of glutathione peroxidase (GPX) at 6 and 9 days. An increase in steady-state mRNA levels of copper, zinc-containing superoxide dismutase (CuZnSOD) was observed at 6 days. Exposure to asbestos aiso resulted in overall increased enzyme activities of catalase, GPX and total SOD in lung. In contrast, silica caused a dramatic increase in steady-state levels of MnSOD mRNA at all time periods and an increase in GPX mRNA levels at 9 days. Activities of AOE remained unchanged in silica-exposed lungs. In both models, increases in gene expression of MnSOD correlated with increased amounts of MnSOD immunoreactive protein in lung and the pattern and extent of inflammation. These data indicate that the profiles of $\mathrm{AOE}$ are dissimilar during the development of experimental asbestosis or silicosis and suggest different mechanisms of lung defense in response to these minerals.

\section{Introduction}

Active oxygen species (AOS) may play a key role in the initial lung response to asbestos and silica (1-3). AOS can be catalyzed directly by redox reactions cecuring on the surfaces of both mineral dusts (4-8). Moreover, both minerals are phagocytized by alveolar macrophages (AMs) and cause a respiratory burst characterized by release of AOS (reviewed in 9). Chemotactic and fibrogenic mediators are also liberated from these cells in a cascading process culminating in pulmonary fibrosis (reviewed in 10).

Both in vitro and in vivo experiments indicate a causal relationship between AOS and the development of mineral-induced cell damage, inflammation and pulmonary fibrosis. Cytotoxicity induced by various types of asbestos or silica in in vitro systems is decreased after addition of antioxidants (3,11-15). Moreover, the addition of oxidant generating systems to lung fibroblasts (16) and tracheal epithelial cells (17) in vitro results in alterations in cell differentiation 
and proliferation which might be important in the pathogenesis of disease. For example, addition of crocidolite asbestos or xanthine plus xanthine oxidase, a generating system producing a spectrum of AOS, to normal rat lung fibroblasts, causes increases in total cell-associated collagen (16). Both xanthine plus xanthine oxidase (17) and hydrogen peroxide $\left(\mathrm{H}_{2} \mathrm{O}_{2}\right)(18)$ cause hyperplasia and squamous metaplasia in hamster tracheal epithelium. Continuous administration of polyethylene glycol (PEG)-conjugated catalase ameliorates pulmonary injury, inflammation and fibrosis in rat lung after inhalation of crocidolite asbestos, an observation confirming the importance of AOS in asbestosis (1).

The lung is equipped with an elaborate defense system of antioxidant enzymes (AOE), sulfhydryl-containing molecules and naturally occurring scavengers of AOS (ceruloplasmin, vitamin E, etc.) occurring in different compartments of the lung. Pulmonary injury might ensue when the oxidant-antioxidant balance is disturbed either by increased oxidant stress or by abnormal functioning of the antioxidant system (19-21).

Little information is available in the scientific literature on the localization or regulation of $A O E$ in lungs after exposure to pathogenic particulates. In earlier studies, we showed that inhalation of crocidolite asbestos caused an increase in steady-state mRNA levels of MnSOD in rat lung (22). Moreover, activities of total SOD, catalase and GPX were increased in rat lung after exposure to asbestos (23).

Most recently, we examined steady-state mRNA levels of MnSOD in a tracheal epithelial cell line after exposure to $\mathrm{H}_{2} \mathrm{O}_{2}$ or xanthine and xanthine oxidase (24). The latter generating system of AOS caused increased gene expression of MnSOD while steady-state levels of CuZnSOD, catalase and GPX remained unchanged. The present study was conducted to determine if inhalation of cristobalite, a crystalline silicon dioxide particle (defined as a $<3: 1$ length to diameter ratio) or crocidolite, an amphibole asbestos fiber ( $>3: 1$ ratio), induced changes in steady-state mRNA levels, immunoreactive protein and activities of certain AOE (MnSOD, copper zinc-SOD [CuZnSOD], GPX, and catalase) in lung. Furthermore we were interested in whether changes in AOE profiles would correlate with patterns of inflammation, pulmonary injury and fibrosis in rodent inhalation models of disease.

\section{Materials And Methods}

Exposure: Male Fischer 344 rats, weighing 200-250 grams were exposed to National Institute of Environmental Health Sciences crocidolite asbestos (7-10 $\mathrm{mg} / \mathrm{m}^{3}$ air) or $\alpha$-cristobalite $\left(7-10 \mathrm{mg} / \mathrm{m}^{3}\right.$ air; C \& E Mineral Corp., King of Prussia, PA) for $6 \mathrm{hr} /$ day, 5 days/week for 10 days as described previously (1). The mass median aerodynamic diameters were determined using an eight stage 
Sierra Impactor (Sierra instruments, Carmel Valley, CA). The mass median aerodynamic diameters ( \pm geometric standard deviation) were $0.8 \pm 3.5 \mu \mathrm{m}$ for crocidolite and $1.5 \pm 2.6 \mu \mathrm{m}$ for cristobalite. Asbestos fibers were generated using a modified Timbrell dust generator (25) while cristobalite was aerosolized using a Wright dust feeder (26). Sham control animals were placed in dust-free chambers and handled identically.

Chemicals: Catalase was purchased from Worthington Biochemical Co. (St. Louis, MO), superoxide dismutase (bovine copper-zinc) from Data Diagnostics, Inc. (Mountain View, CA), pentobarbital from Fort Dodge Laboratories, Inc. (Fort Dodge, IA). Phenol was obtained from Anachemia (Rouses Point, NY), chloroform from Fisher, $\left[\alpha-{ }^{32} \mathrm{P}\right] \mathrm{dATP}(3,000 \mathrm{Ci} / \mathrm{mmol})$ from Dupont-New England Nuclear, ${ }^{125} \mathrm{I}(16 \mathrm{mCi} / \mu \mathrm{g})$ from Amersham Corp. $\mathrm{Ca}^{2+} \mathrm{Mg}^{2+}$ free phosphate buffered saline (CMFPBS) and prestained, low range, protein molecular weight standards from GIBCO. Biorad dye reagent, acrylamide, bis, ammonium persulfate, TEMED, tris, glycine, horseradish peroxidase color development reagent, Tween-20, and Coomassie blue stain were obtained from Bio-Rad. All other chemicals were obtained from Sigma.

Preparation of lungs: After 1, 3, 6 and 9 days of exposure and at 14 days after cessation of a 10 day exposure to crocidolite or cristobalite, rats $(n=4 /$ exposure group/time period/experiment) were anaesthetized with a lethal intraperitoneal injection of pentobarbital, the chest was opened, and the lungs were perfused with heparinized CMFPBS via the pulmonary artery until the lungs appeared white. The left lung was clamped off with a hemostat and removed for AOE activity assays. Subsequently, the trachea was exposed and cannulated with a 22-gauge needle covered with plastic tubing, and the right lobes were lavaged with CMFPBS $(5 \times 4 \mathrm{ml})$ by gently massaging the chest. After lavage, lungs were flash frozen in liquid nitrogen and stored at $-70^{\circ} \mathrm{C}$ for Northem and Western blot analyses.

Northern blot analysis: Total RNA was extracted from lung tissues according to the procedure of Chomczynski and Sacchi (27). Purity and concentration were determined by measuring UV absorbances at 260 and $280 \mathrm{~nm}$. Fifteen $\mu \mathrm{g}$ of total RNA was denatured and fractionated by electrophoresis on a $1.0 \%$ agarose-formaldehyde gel. After UV examination of RNA migration, RNA was transferred onto nitrocellulose filters (Schleicher and Shuell) and subsequently baked in a vacuum oven for 2 hours at $80^{\circ} \mathrm{C}$. Blots were hybridized $(50 \%$ deionized formamide, $5 X$ SSC, $5 X$ Denhardt's solution, $50 \mu \mathrm{g} / \mathrm{ml}$ Salmon testes DNA, $0.1 \%$ sodium dodecyl sulfate) with $\alpha-{ }^{32} \mathrm{P}$-labeled cDNA probes ovemight at $42^{\circ} \mathrm{C}$ (28). cDNAs were radiolabeled according to Feinberg and Vogelstein (29) using a Prime-a-Gene labeling system (Promega, Madison, WI). Blots were 
washed and visualized by exposure to Kodak X-Omat AR film (Rochester, NY) at $-70^{\circ} \mathrm{C}$ using intensifying screens. In addition, radioactivity on blots was directly quantitated using a Betascope blot analyzer (Betagen Corp., Waltham, MA). For quantitation of MnSOD mRNA, the $~ 1$-kilobase mRNA species was scanned (see below). Rat MnSOD and CuZnSOD cDNA probes were generously provided by Y.-S Ho, Duke University, Durham, NC (30,31). A rat catalase cDNA probe was obtained from S. Furata, Shinshu University School of Medicine, Matsumoto, Japan (32), and a mouse GPX probe from G. Mullenbach, Chiron Corp, Emeryville, CA (36). A probe for $28 \mathrm{~S}$ ribosomal RNA, obtained from Dr. K. Cutroneo, Dept of Biochemistry, University of Vermont, Burlington, VT was used as a loading control.

Antioxidant enzyme activities: The left lungs were minced and homogenized in phosphate buffer $(0.05 \mathrm{M}, 1 \mathrm{mM}$ EDTA, pH 7.8) on ice using a Polytron apparatus (Brinkman, Westbury, NY) ( $2 \times 60$ seconds at the highest speed) and centrifuged at $14,000 \mathrm{rpm}\left(4^{\circ} \mathrm{C}\right)$. Protein content of lung homogenates was assessed according to the procedure of Bradford (34). Small aliquots of homogenized left lung were stored at $-70^{\circ} \mathrm{C}$ until $\mathrm{AOE}$ assays were performed. $\mathrm{AOE}$ activity analyses were performed as described previously (23). Enzyme activities were expressed per mg protein. Experiments were performed in duplicate (cristobalite) or triplicate (crocidolite), and results of pooled experiments were expressed as a percentage of values found in sham control rats.

Western blot analysis: The enzyme activity assay for SOD used here does not distinguish between MnSOD and CuZnSOD activity. Therefore, Western blot analysis was performed to determine whether or not mRNA levels of MnSOD or $\mathrm{CuZnSOD}$ correlated with respective immunoreactive protein. Small aliquots of lung tissue were homogenized as described above. Supematants were stored at $-70^{\circ} \mathrm{C}$. Prior to electrophoresis, samples were lyophilized and reconstituted in electrophoresis sample buffer and electrophoresed in $15 \%$ sodium dodecyl sulfate-polyacrylamide gels as described previously (35). After electrophoresis, proteins were transferred onto nitrocellulose using a semidry electroblotter (Kirkegaard and Perry, Gaithersburg, MD). Blots were stored at $4^{\circ} \mathrm{C}$ in PBS until analysis. Nonspecific binding was blocked by incubating blots for 30 minutes in PBS-Tween (.05\%). Subsequently, blots were incubated with primary antibody for 1 hour. Anti- human kidney MnSOD antibody was generously provided by Dr. L.W.Oberley, University of Iowa, Iowa City, IA (36), and anti-rat CuZnSOD was obtained from Dr. D. M. Massaro, Georgetown University, Washington, DC (37). Blots were washed with PBS-Tween ( 3 x 4 minutes) and incubated with a biotinylated secondary antibody (Vector laboratories, Burlingame CA). Protein bands were visualized with the avidinbiotin peroxidase system according to the manufacturer (Vector laboratories, 
Burlingame, CA). After protein transfer, gels were stained with Coomassie blue stain to assess loading homogeneity. In order to quantitate Western blots, unconjugated secondary antibody (Vector Laboratories, Burlingame, CA) was labeled with ${ }^{125} \mathrm{I}$ to a specific activity of $6-7 \mu \mathrm{Ci} / \mu \mathrm{g}$ according to the Iodogen method (38). Purified MnSOD (chicken liver, provided by Dr. L. W. Oberley, University of Iowa, Iowa City, IA) was included in each gel as a standard. Lung proteins ( $20 \mu \mathrm{g} / \mathrm{lane})$ and purified MnSOD were electrophoresed and transferred as described above. Blots were incubated with primary antibodies, washed with PBS-tween and subsequently incubated with ${ }^{125}$ I-conjugated secondary antibodies for 1 hour. Blots were washed with PBS-tween ( 3 X 30 minutes), air dried and exposed to Kodak X-Omat AR film at room temperature. Bands were cut out of the nitrocellulose blots, and their ${ }^{125} \mathrm{I}$ content was counted in a gamma counter (Micromedic Inc., Horsham, PA). Amounts of AOE protein in lung samples were determined from comparison with $\mathrm{AOE}$ standards.

Differential and total cell counts in bronchoalveolar lavage (BAL): Lavaged cells from right lung lobes were centrifuged at $1500 \mathrm{rpm}$ for 10 minutes at $4^{\circ} \mathrm{C}$, and cells were counted using a hemocytometer. Cytospin slides were prepared using a cytospin apparatus (Shandon, Swickely, PA) and stained with May Grunwald and Giemsa stains as described previously (1). Differential cell counts were obtained by counting at least 500 cells/slide on 2 slides/animal.

Biochemical indices of pulmonary damage in BAL: In separate experiments using the same exposure regimen, pulmonary damage and indicators of pulmonary fibrosis were assessed in additional rats $(n=4 /$ exposure group/time period) after 5 and 10 days of exposure and at 1 month after cessation of exposure. BAL was performed as described above, and cells were centrifuged at $1500 \mathrm{rpm}$ for 10 minutes at $4^{\circ} \mathrm{C}$. Cell-free supernatants from BAL then were assayed immediately for lactate dehydrogenase (LDH) (39) and alkaline phosphatase (40). Protein was determined in cell-free BAL fluids (34) which were stored at $-20^{\circ} \mathrm{C}$ until analysis.

Biochemical index of fibrosis: The upper lobe of the right lung was removed for analysis of hydroxyproline as reported previously $(1,41)$.

Statistical analysis: All results were evaluated with one-way analysis of variance with correction for multiple comparisons (Duncan's procedure). Pearsons correlations were computed in order to determine whether the extent of the inflammatory response (cell totals and differentials in BAL) of all groups combined correlated with steady-state mRNA levels of MnSOD. 


\section{Results}

Gene expression of $A O E$ : Steady-state mRNA levels of $A O E$ in rat lung after exposure to mineral dusts are shown in Figure 1. Since results in Figure 1 are expressed as percentages of sham controls, Table $\mathrm{I}$ is provided to illustrate actual control values (cpm) at individual time periods. Inhalation of asbestos caused significant increases in GPX and MnSOD mRNA levels in rat lung when compared to sham controls at various timepoints during exposure. A slight but statistically significant increase in CuZnSOD mRNA expression also was observed after 6 days of exposure to asbestos. Catalase mRNA expression in lung remained unaffected or was decreased after inhalation of asbestos.

The patterns of steady-state mRNA expression of AOE in lung were different after inhalation of silica. As shown in Figure 1, inhalation of silica caused dramatic increases in MnSOD mRNA levels at all time points. MnSOD mRNA levels also remained elevated after cessation of exposure. Gene expression of other $\mathrm{AOE}$ after exposure to silica were variable. In general, no striking changes in steady-state mRNA levels of other AOE were observed in silica-exposed rats. However, a significant increase in GPX mRNA levels was observed after 9 days of exposure whereas expression of CuZnSOD was significantly decreased at 14 days after cessation of exposure.

Activity of $A O E$ : Four individual inhalation experiments were conducted to assess AOE activity following exposure to silica or asbestos. Two experiments included sham and asbestos-exposed rats, one included sham and silica-exposed rats, and one included sham, silica and asbestos-exposed rats. Combined results from all experiments are shown in Figure 2. Data from individual experiments were analyzed separately because of significant inter-experimental variability. Thus, significant values are not presented in Figure 2, but discussed below. GPX activities in asbestos-exposed rat lungs were significantly elevated $(p<0.05)$ in all experiments, with the greatest differences at days 9 and 14 days post exposure. Total SOD activity was significantly elevated $(p<0.05)$ in asbestosexposed rats in one experiment, whereas catalase activity was elevated significantly $(p<0.05)$ in two experiments. No increases in activities of AOE were observed after inhalation of cristobalite silica.

Northern and western blot analyses: Western blot analysis was used to determine if steady-state levels of mRNA correlated with amounts of immunoreactive proteins. Figure 3 shows Northern and Western blots of MnSOD and CuZnSOD in rat lungs after 9 days of exposure to mineral dusts. This was the timepoint at which increases in MnSOD mRNA expression occurred in both inhalation models. We observed that at least 5 species of mRNA for MnSOD occur in rat lung, as has been reported previously in human and rat lungs $(42,43)$. 


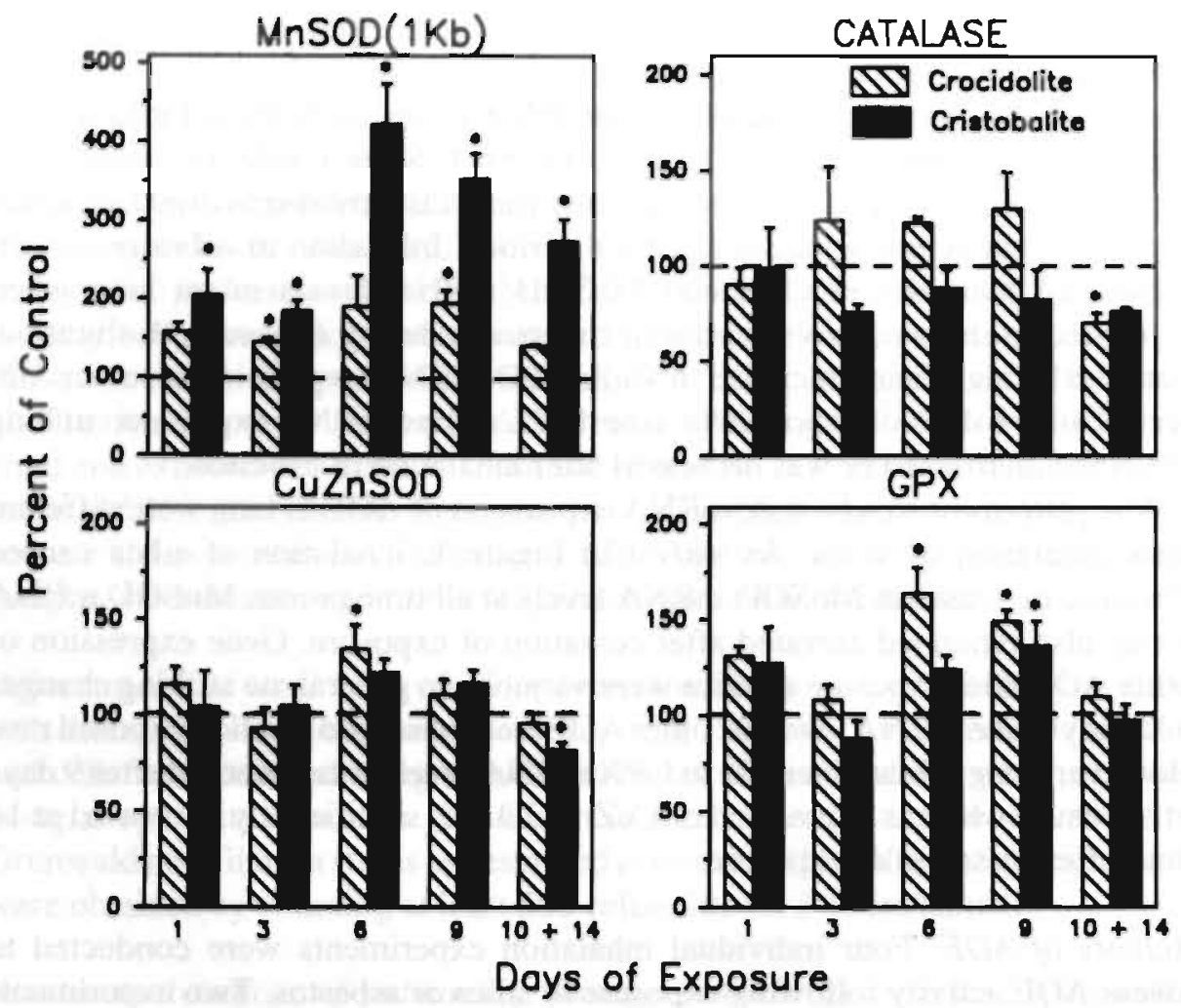

Figure 1: Steady-state mRNA levels of AOE in rat lung after 1,3,6 and 9 days of inhalation of asbestos or silica and at 14 days after cessation of exposure. Results were obtained from Betascope blot analyses. For MnSOD, the most abundant species ( I kilobase) was quantitated. A $28 \mathrm{~S}$ ribosomal probe was used in order to confirm loading homogeneity (not shown). Data are presented as percentages of mean control values $\pm S . E . \quad(n=4$ rats/exposure group/time period). Note the differences in scale between the ordinates of MnSOD compared to the other AOE. Analysis of variance were performed on actual values. ${ }^{*} p<$ 0.05 compared to sham controls.

Inhalation of asbestos or silica caused increases in MnSOD mRNA expression (Figure 3A) which correlated directly with increases in MnSOD immunoreactive protein (Figure 3B). In contrast, CuZnSOD mRNA expression and immunoreactive protein remained relatively unchanged after mineral dust inhalation. Table II shows amounts of MnSOD immunoreactive protein in lung after 9 days of mineral exposure as well as 14 days after cessation of exposure. The magnitude in increases of MnSOD immunoreactive protein after exposure to asbestos or silica correlated with elevated levels of MnSOD gene expression observed after inhalation of minerals. 
Table I: Steady-state mRNA levels of antioxidant enzymes in sham control rat lungs at various time periods.

\begin{tabular}{lcllr}
\hline & MnSOD & CuZnSOD & \multicolumn{1}{l}{ Catalase } & \multicolumn{1}{l}{ GPX } \\
\hline Day 1 & $4.23 \pm 0.08$ & $33.8 \pm 2.09$ & $6.53 \pm 0.33$ & $9.28 \pm 0.51$ \\
Day 3 & $11.5 \pm 1.49$ & $31.3 \pm 3.2$ & $9.58 \pm 0.79$ & $44.5 \pm 4.17$ \\
Day 6 & $3.4 \pm 0.41$ & $16.43 \pm 0.28$ & $4.83 \pm 0.15$ & $20.05 \pm 0.75$ \\
Day 9 & $2.78 \pm 0.03$ & $56.63 \pm 2.39$ & $6.93 \pm 0.78$ & $9.65 \pm 0.10$ \\
Day 10+14 & $8.85 \pm 0.20$ & $47.4 \pm 1.58$ & $9.3 \pm 0.94$ & $8.68 \pm 0.93$ \\
\hline
\end{tabular}

Northern blot analyses were performed as described in the text and quantitated using a Betascope blot analyzer. Data $\pm S$.E. from pooled experiments $(n=4$ rats/experiment $)$ are presented. Data are expressed in counts per minute.

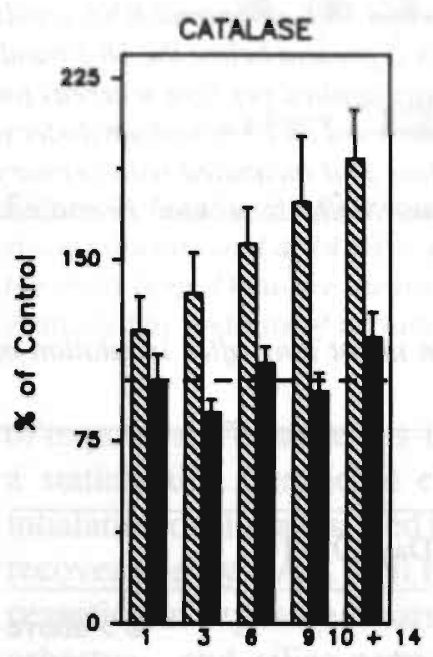

NIV Crocidolite
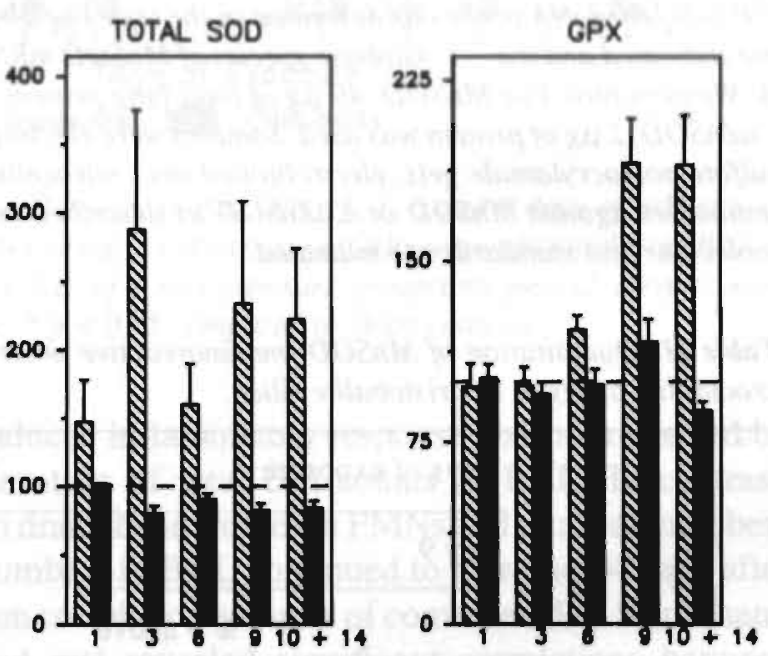

Days of Exposure

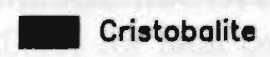

Figure 2: Lung AOE activities after 1,3,6 and 9 days of exposure to asbestos or silica and at 14 days after cessation of exposure. Data are expressed as percentages of sham control values. Shown are means \pm S.E. of these percentages. Analysis of variance was performed on actual values of individual experiments (see Results section).

Cell numbers and types in bronchoalveolar lavage (BAL): Inhalation of asbestos caused a rapid increase in PMNs and lymphocytes in BAL (Figure 4). However, the percentage of PMNs decreased in asbestos-exposed rats after the cessation 


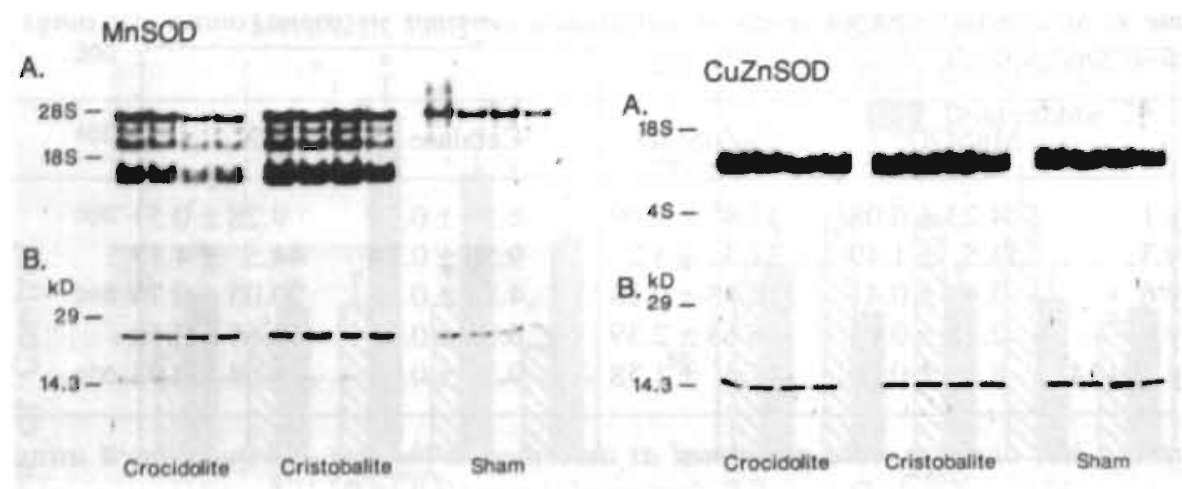

Figure 3: Northern and Western blot analyses of MnSOD and CuZnSOD after 9 days of exposure to asbestos or silica. A: Northern blot. $15 \mu \mathrm{g}$ of total RNA from rat lung was fractionated on an agarose-formaldehyde gel, blotted onto nitrocellulose and hybridized to ${ }^{32} \mathrm{P}$-labeled cDNA probes as described in the text. The $28 \mathrm{~S}$ and $18 \mathrm{~S}$ ribosomal RNA bands are indicated and the $\sim 1$ - kilobase species of MnSOD mRNA is present below the $18 \mathrm{~S}$ band. B: Western blot. For MnSOD, $40 \mu \mathrm{g}$ of total lung proiein was applied per lane whereas for CuZnSOD. $2 \mu \mathrm{g}$ of protein was used. Samples were electrophoresed on $15 \%$ sodium dodecyl sulfare-polyacrylamide gels, electroblotted onto nitrocellulose and incubated with primary antibodies against MnSOD or CUZnSOD as described in the Methods section. Prestained molecular size standards are indicated.

Table II: Quantitation of MnSOD immunoreactive protein in rat lung afier inhalation of crocidolite asbestos or cristobalite silica.

Days of exposure

\begin{tabular}{|c|c|c|c|c|}
\hline & & & & \\
\hline & Day 9 & & Day $10+14$ & \\
\hline & & $\%>$ above & & $\%>$ above \\
\hline 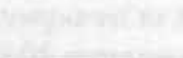 & Mean \pm SEM & Control & Mean \pm SEM & Control \\
\hline Sham & $23.16 \pm 1.36$ & - & $19.18 \pm 1.26$ & - \\
\hline Crocidolite & $27.82 \pm 2.28$ & 120.1 & $24.94 \pm 1.79 *$ & 130 \\
\hline ristobalite & $60.83 \pm 5.63^{*}$ & 262.7 & $46.28 \pm 3.34^{*}$ & 241.3 \\
\hline
\end{tabular}

Twenty $\mu \mathrm{g}$ of protein from lung and purified MnSOD protein standards were electrophoresed, electroblotted, and incubated with primary anti-MnSOD antibody and ${ }^{125}$ I-conjugated secondary antibody as described in the text. Radioactivity of bands was counted in a gamma counter. Amounts of MnSOD in lung samples were determined from standards. Results here show nanograms of immunoreactive protein (mean \pm S.E. of 4 rats/exposure group/time period). Results were evaluated by analysis of variance.

* $P<0.05$ compared with sham controls. 

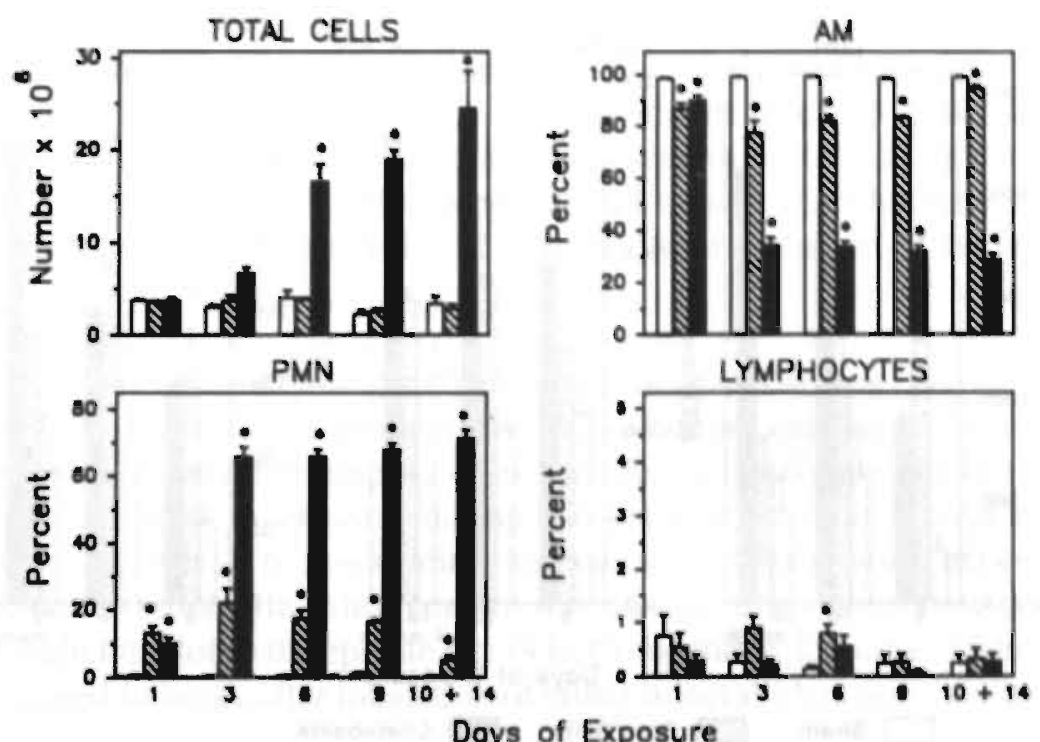

$\square$ Shom $\mathrm{BW}$ Crocidolite

Cristobatite

Figure 4: Total and differential cell counts in BAL after 1, 3, 6 and 9 days of ashestos or silica exposure and at 14 days after cessation of exposure. Cells were obtained from BAL of the right lung. Data are means $\pm S . E$. of 4 ratslexposure group/time period. Results were evaluated by analysis of variance. ${ }^{*} p<0.05$ compared to sham controls.

of exposure. The asbestos-induced inflammatory response was not reflected by a statistically significant elevation of total cell counts in BAL. In contrast, inhalation of silica resulted in dramatic increases in PMNs and total cell numbers recoverable by BAL. Cell numbers in BAL continued to increase 14 days after cessation of exposure. Pearson correlation analysis of combined data from sham, asbestos-, and silica-exposed rats revealed significant correlations between inflammatory cells in BAL and MnSOD mRNA expression in lung. Correlation coefficients were: $r=0.53(p<0.01)$ for total cell number in BAL, $r=0.58$, $(p<0.01)$ for total number of PMNs, and $r=0.28(p<0.05)$ for total number of lymphocytes in BAL.

Indices of pulmonary damage in BAL: Indices of pulmonary damage after inhalation of asbestos or silica are shown in Figure 5. In general, elevations in $\mathrm{LDH}$, alkaline phosphatase, and protein levels in BAL correlated with the degree of inflammatory cell influx in BAL. Inhalation of asbestos resulted in increases in $\mathrm{LDH}$ after 5 days of exposure and in alkaline phosphatase, and protein in BAL after 10 days of exposure. One month after cessation of exposure, enzymes and protein in BAL returned to control levels. Silica exposure resulted in increases 

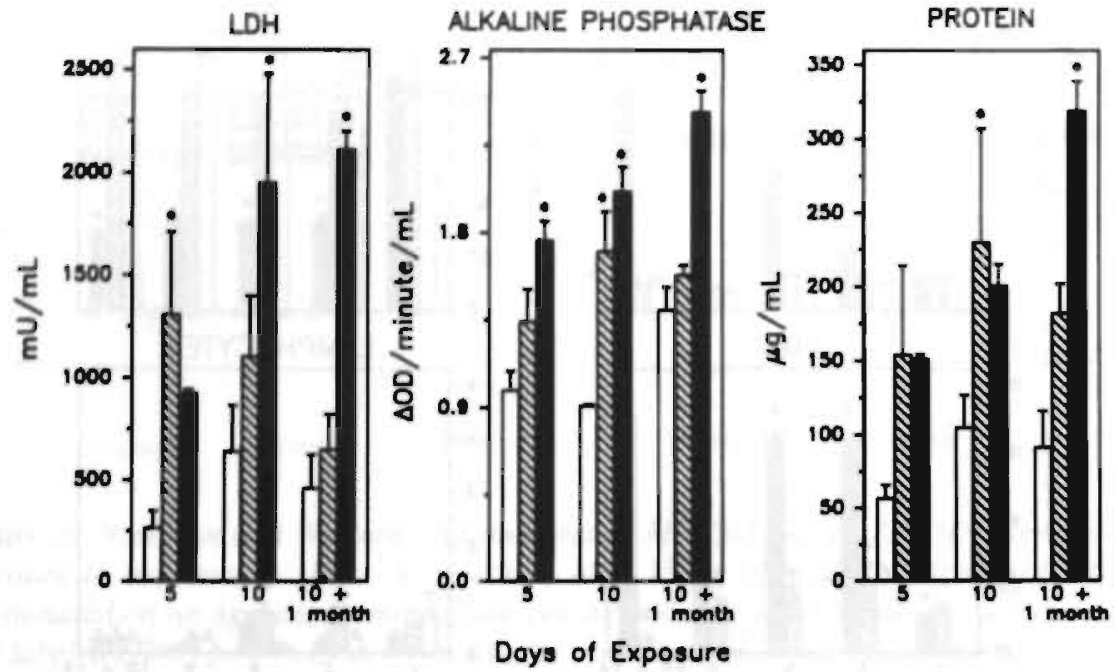

Shom Crocidolite

Cristobalite

Figure 5: Indices of pulmonary damage after 5 and 10 days inhalation of minerals and 1 month after cessation of a 10-day exposure period. Data are means $\pm S$.E. of 4 ratslexposure group/time period. Results were evaluated by analysis of variance. ${ }^{*} p<0.05$ compared to sham controls.

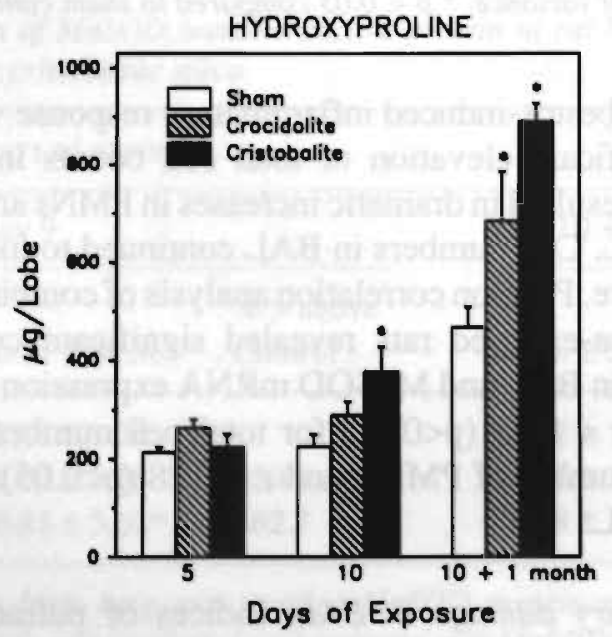

Figure 6: Hydroxyproline levels in the lungs of mineral-exposed rats and sham controls. Data are presented as means $\pm S . E$. of 4 ratslexposure group/time period. Results were evaluated by analysis of variance. ${ }^{*} p<0.05$ compared to sham controls. 
of alkaline phosphatase in BAL at all time points compared to sham rats. $\mathrm{LDH}$ in BAL was increased in silica-exposed rats after 10 days of exposure and at I month after cessation of exposure, whereas protein levels in BAL were increased significantly 1 month after cessation of exposure to silica. In contrast to pattems observed in asbestos-exposed rats, all indices of pulmonary damage were increased most dramatically at 1 month after cessation of exposure to silica.

Hydroxyproline content of lungs: Hydroxyproline levels in lung (Figure 6) were increased at 1 month after cessation of asbestos exposure. In contrast, hydroxyproline content in lung was elevated after only 10 days of silica inhalation and continued to increase during the elaboration of a typical nodular pulmonary fibrosis. To assess dust burdens in rat lung after exposure to crocidolite or cristobalite, silica content was measured at similar time points in middle right lung lobes of separate rats (44). Comparable amounts of silica were demonstrated in lungs after inhalation of either mineral (data not shown).

\section{DISCUSSION}

Inhalation of crocidolite asbestos or cristobalite silica by rats results in the development of pulmonary fibrosis albeit of dissimilar histopathologic features. At equal mass concentrations in air, the two agents also elicit different profiles of inflammation and lung injury as evidenced by BAL analyses. Increased cellularity and markers of lung injury in BAL appeared to resolve after cessation of exposure to asbestos, but continue to increase after cessation of exposure to silica. These dissimilar responses do not appear to reflect a different lung retention of these minerals. Profiles of AOE gene expression and activity in lungs were distinct after inhalation of asbestos or silica, an observation suggesting different patterns of lung defense and/or repair in these inhalation models. Inhalation of asbestos resulted in altered steady-state mRNA levels of $A O E$ and caused general increases in activities of AOE in lung. Inhalation of silica caused a dramatic increase in steady-state levels of MnSOD mRNA and immunoreactive protein, but only minor changes in gene expression of other AOE. Interestingly, no increases in activities of $\mathrm{AOE}$ in lung were observed after inhalation of silica.

Several explanations are possible for the dissimilar pattern of AOE activities after exposure to asbestos or silica. First, proteases and AOS released by elevated numbers of PMNs and AMs in the cristobalite model may degrade AOE. For example, AOS or stimulated PMNs can inactivate enzymes including AOE (45-47). Thus, should induction of lung AOE occur in the model of silicosis, elevated AOE activities might not be observed if these enzymes are 
inactivated. This phenomenon could explain why increased gene expression and immunoreactive protein of MnSOD were observed in silica-exposed rats in the absence of increased total SOD activity. Altematively, the proportion of MnSOD to CuZnSOD might be small in rat lungs, and increases in MnSOD activity would not be detectable using our present enzyme assay. We are currently addressing this question using activity gel analyses.

The different chemical composition and geometry of crocidolite asbestos versus cristobalite silica might govern their ability to generate AOS. For example, crushing or grinding of silica generates various silicon-based radicals as a result of the interaction of cleaved $\mathrm{Si}-\mathrm{O}-\mathrm{Si}$ bonds with atmospheric components $(4,5)$. Moreover, hydroxyl $(\mathrm{OH})$ radicals are generated in aqueous suspensions of freshly ground quartz (5). The $\mathrm{Fe}^{3+}$ on the surface of crocidolite fibers is thought to drive reactions such as the Haber-Weiss (modified Fenton) reaction which generates $\mathrm{OH}$ from $\mathrm{O}_{2}^{-}$and $\mathrm{H}_{2} \mathrm{O}_{2}$ (6-8). In addition to these acellular mechanisms of silicate-induced generation of $\mathrm{AOS}$, the fibrous nature of asbestos may cause increased production of AOS from phagocytes or other cell types in lung. Since long, thin fibers are incompletely phagocytized by AMs, more $\mathrm{O}_{2}^{-}$is produced from fiber-exposed cells in comparison to cells exposed to chemically identical particles (48). In contrast to asbestos fibers, silica particles are small enough to be phagocytized and accumulate in AMs in membranebound phagolysosomes (49). Thus, the amounts, localization, and types of AOS produced by cellular or acellular mechanisms in response to silica or asbestos may be dissimilar in the lung.

Results of the present study indicate that $\mathrm{AOE}$ are not coordinately regulated in lung after insult by minerals. Our data support a body of growing information suggesting that different oxidant insults result in unique patterns of $\mathrm{AOE}$ induction. For example, exposure of hamster tracheal epithelial cells to xanthine and xanthine oxidase results in a selective induction of MnSOD gene expression and immunoreactive protein, whereas addition of $\mathrm{H}_{2} \mathrm{O}_{2}$ results in increased catalase mRNA expression (24).

Exposure to cristobalite produces marked cellularity in BAL and increases in alkaline phosphatase, a marker of type II cell damage and/or proliferation (50). It is well known that the type II pneumocyte is important in the repair of alveolar epithelium after injury (51) and responds to oxidant stress (such as hyperoxia) by increases in AOE $(51,52)$. Recently we have shown by ultrastructural immunocytochemistry that inhalation of either crocidolite asbestos or cristobalite silica results in quantitative increases in MnSOD protein in the mitochondria of type II pneumocytes (53). Thus, it appears that adaptive responses to oxidant injury occur in type II pneumocytes after exposure to these minerals.

Some studies indicate the involvement of cytokines in gene regulation of AOE after mineral exposure. For example, exposure of mononuclear phagocytes to asbestos or silica in vitro causes release of the proinflammatory cytokines, 
tumor necrosis factor (TNF) and interleukin-1 (IL-1) (54-57), both of which induce MnSOD mRNA expression in a variety of cell types (58-62). Under these circumstances, coordinate increases in expression of CuZnSOD and other AOE are not observed (59-62). These observations suggest that TNF and IL-1 may regulate gene expression of MnSOD directly in lung cells.

In recent studies using the same inhalation protocols as described here, we observed increases in TNF mRNA expression in rat lung after inhalation of asbestos or silica. In support of our findings, a recent study showed an increase in TNF mRNA in lungs of mice after intratracheal instillation of silica (63). Administration of anti-TNF antibody prevented collagen deposition in silica-exposed mice whereas infusion of mouse recombinant TNF augmented deposition of collagen in the lungs of these animals (63). These results indicate that TNF may be intrinsic to fibrogenesis in the lung and the development of silicosis.

Continuous administration of PEG-conjugated catalase to rats ameliorates pulmonary damage, inflammation and extent of pulmonary fibrosis associated with inhalation of crocidolite asbestos (1), supporting a cause and effect relationship between AOS and the pathogenesis of asbestosis. Apparently, the induction of AOE by asbestos in the lungs of rats is insufficient to prevent lung injury, and fibrosis develops. However, the airborne concentrations of asbestos fibers used here are high, albeit comparable to some workplace exposures before the enactment of occupational standards for asbestos. Interestingly enough, inflammation, $\mathrm{LDH}$, alkaline phospatase and protein levels in BAL diminish after cessation of exposure to asbestos while AOE activities are still increased. Perhaps a causal relationship exists between increases in AOE and the decrease in parameters of lung injury occurring in this inhalation model of disease.

\section{Acknowledgements}

We thank Janet Petruska and Lucy Trombley for their assistance with BAL, and Rhoda Rowell for preparing the manuscript.

This project was funded by National Institutes of Health Grant R01 HL 39469 , Pulmonary Specialized Center of Research in Occupational and Immunologic Lung Diseases Grant PHS 14212 and a grant from the Environmental Protection Agency. 


\section{REFERENCES}

1 Mossman, B.T., Marsh, J.P., Gilbert, R., Hardwick, D., Sesko, A., Hill, S., Shatos, M.A., Doherty, J., Bergeron, M., Adler, K.B., Hemenway, D., Mickey, R., Vacek, P., Kagan, E. (1990) Am. Rev. Respir. Dis. 141, 1266-1271

2 Borm, P., Palmen, N., Engelen, J., Buurman, W. (1989) Effects of Mineral Dusts on Cells. pp. 173-180, Springer-Verlag, Berlin Heidelberg

3 Mossman, B.T., Marsh, J.P. (1989) Environ. Health Perspect. 81, 91-94

4 Fubini, B., Bolis, V., Giamello, E., Pugliese, L. Volante, M. (1989) Effects of Mineral Dusts on Cells. pp. 205-214, Springer-Verlag, Berlin Heidelberg

5 Dalal, N.S., Shi, X. Vallyathan, V. (1989) Effects of Mineral Dusts on Cells. pp. 265-272, Springer-Verlag, Berlin Heidelberg

6 Eberhart, M.K., Roman-Franco, A.A., Quiles, M.R. (1985) Environ. Res. 37, 287-292

7 Weilzman, S.A., Graceffa, P. (1984) Arch. Biochem. Biophys. 228, 373-376

8 Zalma, R., Bonneau, L., Guignard, J., Pezerat, H. (1987) Can. J. Chem. 65, 2338-2341

9 Bowden, D.H. (1987) Exp. Lung Res. 12, 89-107

10 Rom, W.N., Travis, W.D., Brody, A.R. (1991) Am. Rev. Respir. Dis. 143, 408-422

11 Mossman, B.T., Marsh, J.P., Shatos, M.A. (1986) Lab. Invest. 54, 204-212

12 Shatos, M.A., Doherty, J.M., Marsh, J.P., Mossman, B.T. (1987) Environ. Res. 44, 103-116

13 Goodlick, L.A., Kane, A.B. (1986) Cancer Res. 46, 5558-5566

14 Goodlick, L.A., Pietras, L.A., Kane, A.B. (1989) Am. Rev. Respir. Dis. 139, 1265-1273

15 Voisin, C., Aerts, C., Wallaert, B. (1987) Clin. Respir. Physiol. 23, 309-313

16 Mossman, B.T., Marsh, J.P., Shatos, M.A., Doherty, J., Gilbert, R., Hill, S. (1987) Drug and Chem. Toxicol. 10, 157-180

17 Mossman, B.T., Marsh, J.P., Dantona, R., Bergeron, M. Senior, A. (1990) Biology, Toxicology and Carcinogenesis of Respiratory Epithelium. pp. 145-154, Hemisphere Publication Corp., New York

18 Radosevich, C.A., Weitzman, S.A. (1989) Carcinogenesis 10, 1943-1946

19 Heffner, J.E., Repine, J.E. (1989) Am. Rev. Respir. Dis. 140, 531-554

20 White, C.W., Repine, J.E. (1985) Exp. Lung Res. 8, 81-96

21 Panus, P.C., Shearer, J., Freeman, B.A. (1988) Exp. Lung Res. 14, 959-976

22 Mossman, B.T., Janssen, Y.M.W., Marsh, J.P., Manohar, M., Garrone, M., Shull, S. Hemenway, D. (1990) J. Aerosol Med. 3, S75-S82

23 Janssen, Y.M.W., Marsh, J.P., Absher, M., Borm, P.J.A. Mossman, B.T. (1990) Free Rad. Res. Comms. 11, 53-58

24 Shull, S., Heintz, N.H., Periasamy, M., Manohar, M., Janssen, Y.M.W., Marsh, J.P., Mossman, B.T. (1991) J. Biol. Chem. 266, 24398-24403

25 Hemenway, D.R., McAskill, S.M. (1982) Am. Ind. Hyg. Assoc. J. 43, 874-879

26 Hemenway, D.R., Boudreau, K., Miller, J. (1986) Am. Ind. Hyg. Assoc. J. 47, 301-307

27 Chomczynski, P. Sacchi, N. (1987) Anal. Biochem. 162, 156-159

28 Sambrook, J., Fritsch, E.F. Maniatis, T. (1989) Molecular Cloning: A Laboratory Manual, 2nd Ed., Cold Spring Harbor Laboratory Press, Cold Spring Harbor, NY

29 Feinberg, A.P., Vogelstein, B. (1983) Anal. Biochem. 132, 6-13

$30 \mathrm{Ho}$ YS, Crapo, JD. (1987) Nucl. Acids Res. 15, 10070

31 Ho YS, Crapo, JD. (1987) Nucl. Acids Res. 15, 6746 
32 Furata S, Hayashi H, Hijikata M, Miyazawa S, Osumi T, Hashimoto T. (1986) Proc. Natl. Acad. Sci. USA 83, 313-317

33 Mullenbach GT, Tabrizi A, Irvine BD, Bell GI, Tainer JA, Hallewell RA. (1988) Oxy-radicals in Molecular Biology and Pathology. pp. 313-326, Alan R. Liss, Inc., New York

34 Bradford, M.N. (1976) Anal. Biochem. 72, 248-254

35 Edmondson, S.W., Wu, R. Mossman, B.T. (1990) J. Cell. Physiol. 142, 21-30

36 Oberley, T.D., Oberley, L.W., Slattery, A.F., Lauchner, L.J., and Elwell, J.H. (1990) Am. J. Pathol. 137, 199-214

37 Hass, M.A., Frank, L., Massaro, D. (1982) J. Biol. Chem. 257, 9379-9383

38 Fraker, P.J., Speck Jr., J.C. (1978) Biochem. Biophys. Res. Commun. 80, 849-857

39 Bergmeyer, H.V. (1974) Methods of Enzymatic Analysis. pp. 574-579, Academic Press, NY

40 Reid, J.W., Wilson, I.B. (1971) The Enzymes. pp. 373-380, Academic Press, NY

41 Woessner, J.F. (1961). Arch. Biochem. Biophys. 93, 440-447

42 Wispe, J.R., Clark, J.C., Burhans, M.S., Kropp, K.E., Korfhagen, T.R. Whitsett, J.A. (1989) Biochim. Biophys. Acta. 994, 30-36.

43 Ho, Y.S., Howard, A.J., Crapo, J.D. (1991) Am. J. Respir. Cell. Mol. Biol. 4, 278-286

44 Hemenway, D.R., Absher, M.P., Trombley, L., Vacek, P.M. (1990) Am. Ind. Hyg. Assoc. J. 51, 363-369

45 Kono, Y., Fridovich, I. (1982) J. Biol. Chem. 257, 5751-5754

46 Olivier, C.N. (1987) Arch. Biochem. Biophys. 253, 62-72

47 Panus, P.C., Matalon, S., and Freeman, B.A. (1989) In Vitro Cell Dev. Biol. 25, $821-829$

48 Hansen, K., Mossman, B.T. (1987) Cancer Res. 47, 1681-1686

49 Absher, M.P., Trombley, L., Hemenway, D.R., Mickey, R.M. and Leslie K.O. (1989) Am. J. Pathol. 134, 1243-1251

50 Henderson, R.F. (1984) Environ. Health Perspect. 56, 115-129

$5 I$ Freeman, B.A., Mason, R.J., Williams, M.C., Crapo, J.D. (1986) Exp. Lung Res. 10, 203-222

52 Forman, H.J., Fisher, A.B. (1981) Lab. Invest. 45, 1-6

53 Holley, J.A., Janssen, Y.M.W., Mossman, B.T., Taatjes, D.J. (1992) Am J. Pathol. (In Press)

54 Schmidt, J.A., Oliver, C.N., Lepe-Zuniga, J.L., Green, I., Gery, I. (1984) J. Clin. Invest. 73, 1462-1472

55 Dubois, C., Bissonnette, E., Rola Pleszczynski, M. (1989) Effects of Mineral Dusts on Cells. pp. 359-366, Springer-Verlag, Berlin Heidelberg

56 Driscoll, K.E., Lindenschmidt, R.C., Maurer, J.K., Higgins, J.M. (1989) Effects of Mineral Dusts on Cells. pp. 101-108, Springer-Verlag, Berlin Heidelberg

57 Borm, P.J.A., Palmen, N., Engelen, J.J.M., Buurman, W.A. (1988) Am. Rev. Respir. Dis. 138, 1589-1594

58 Wong, G.H.W., Elwell, J.H., Oberley, L.W., Goeddel, D.V. (1989) Cell 58, 923-931

59 Wong, G.H.W., Goeddel, D.V. (1988) Science 242, $941-944$

60 Masuda, A., Longo, D.L., Kobayashi, Y., Appella, E., Oppenheim, J.J., Matsushima, K. (1988) FASEB J. 2, 3087-3091

61 Visner, G.A., Dougall, W.C., Wilson, J.M., Burr, I.A. Nick, H.S. (1990) J. Biol. Chem. 265, 2856-2864

62 Shaffer, J.B., Treanor, C.P., Del Vecchio, P.J. (1990) Free Rad. Biol. Med. 8, 497-502

63 Piquet, P.F., Kollart, M.A., Grau, G.E., Sappino, A.P., Vassalli, P. (1990) Nature 344, 245-247 


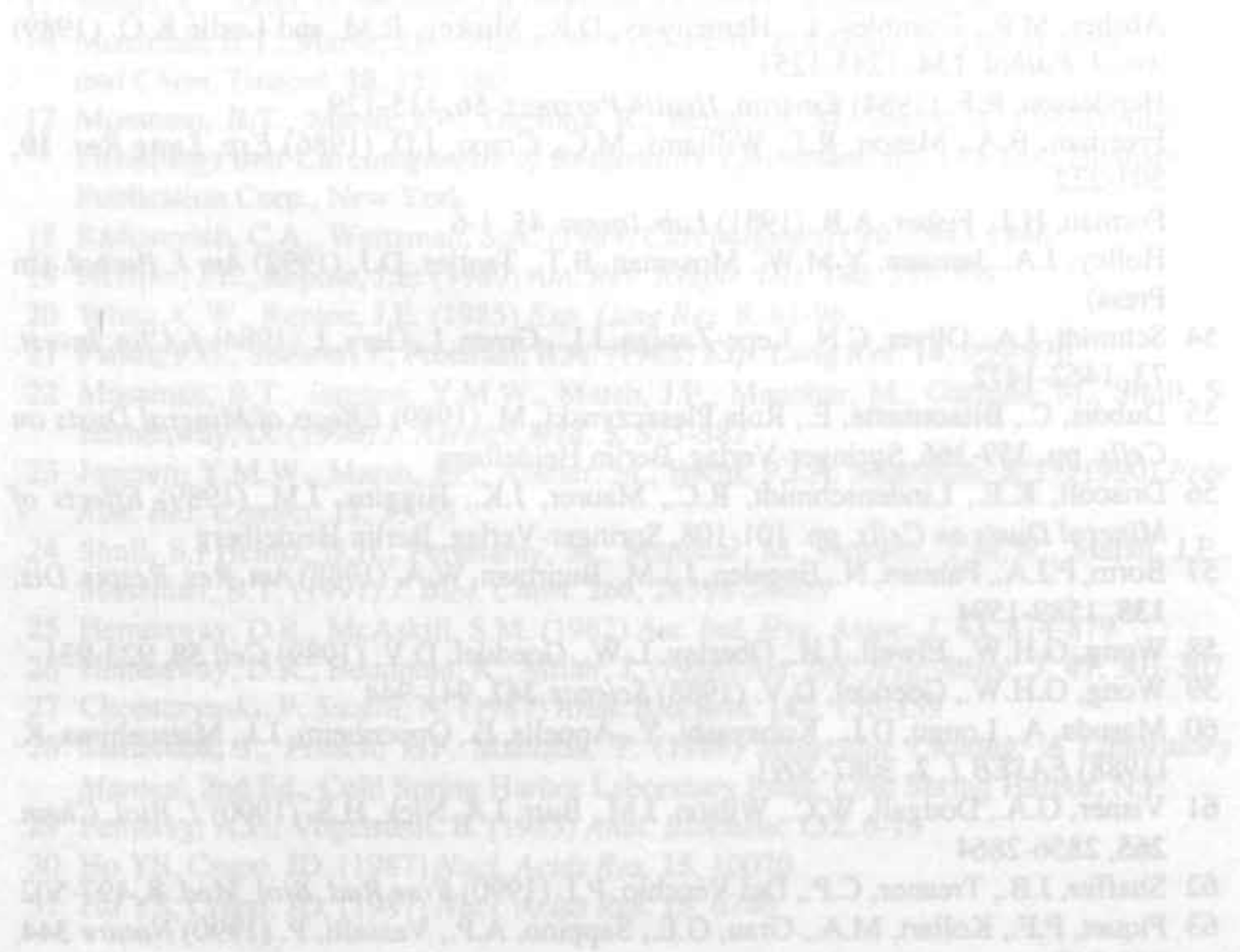




\section{Increased Expression of Manganese-containing Superoxide Dismutase in Rat Lungs after Inhalation of Inflammatory and Fibrogenic Minerals}

Yvonne M W Janssen*, Joanne P Marsh*, Kevin E Driscoll ${ }^{\dagger}$, Paul J A Borm ${ }^{\ddagger}$, Günter Oberdörster ${ }^{\S}$, and Brooke T Mossman*

*Department of Pathology, University of Vermont College of Medicine, Burlington, VT, USA, ${ }^{\dagger}$ Procter and Gamble, Miami Valley Laboratories, Cincinnati, OH, USA, ${ }^{\ddagger}$ Department of Occupational Medicine, University of Limburg, Maastricht, The Netherlands, and ${ }^{8}$ University of Rochester Medical Center, Rochester, NY, USA 


\section{Abstract}

Steady-state mRNA levels and immunoreactive protein for manganese-containing superoxide dismutase (MnSOD) were assayed in rat lungs after subchronic inhalation of the fibrogenic silicon dioxide, cristobalite, or preparations of titanium dioxide $\left(\mathrm{TiO}_{2}\right)$ of different inflammatory and fibrogenic potential. Total and differential cell counts recoverable by bronchoalveolar lavage (BAL) also were measured to ascertain whether induction of certain $\mathrm{AOE}$ correlated with inflammatory responses. Inhalation of cristobalite and ultra-fine $\mathrm{TiO}_{2}$, a particle causing pulmonary inflammation and fibrosis, caused dramatic increases in MnSOD mRNA levels in rat lung which correlated with increases in MnSOD immunoreactive protein. Increases in gene expression of other antioxidant enzymes (AOE) [catalase, glutathione peroxidase (GPX), copper-zinc containing superoxide dismutase (CuZnSOD)] were less striking and did not correlate precisely with inflammatory potential of minerals. Inflammatory changes in BAL correlated directly with steady-state MnSOD mRNA levels in lung. Inhalation of $\mathrm{TiO}_{2}-\mathrm{F}$, a noninflammatory, nonfibrogenic mineral, failed to induce MnSOD or mRNAs for other AOEs. Our data suggest that particles causing inflammation and pulmonary fibrosis increase expression of AOEs in lung, most notably MnSOD. Thus, elevations of MnSOD mRNA levels in lung or BAL may be predictive of lung disease.

\section{Introduction}

Inhalation of mineral dusts in the workplace can lead to the development of pneumoconioses of distinct histopathological features. For example, the crystalline silica, $\alpha$-quartz, is a major cause of silicosis in man when inhaled at high airborne concentrations. Patients develop fibrotic nodules which may occur diffusely in lungs after heavy exposure ${ }^{1}$. Experimental models of silicosis using the silicon dioxide polymorph, cristobalite, also result in the formation of localized silicotic nodules and a massive inflammatory involvement ${ }^{2}$. Other mineral dusts such as titanium dioxide $\left(\mathrm{TiO}_{2}\right)$, gallium oxide or aluminum oxide, have been regarded in the past as "nuisance dusts" because of the absence of adverse pulmonary effects after exposure ${ }^{3,4}$. However, recent studies have demonstrated that high concentrations or ultra-fine variants of these dusts result in severe pulmonary damage, inflammation and fibrosis due to a saturation of particle clearance by alveolar macrophages (AMs) ${ }^{5-7}$. This "overload" situation causes a concomitant, increased access of particles in the interstitium of the lung with the development of pulmonary damage, inflammation and fibrosis ${ }^{6.7}$.

Several studies have demonstrated an important role of active oxygen species in the elaboration of mineral dust-induced pulmonary fibrosis ${ }^{8}$. For example, 
exposure of many cell types to fibrogenic mineral dusts in vitro results in cytotoxicity which can be diminished or prevented by concomitant addition of antioxidants $^{9-12}$. Iron-containing asbestos fibers are Fenton-type catalysts which generate the hydroxyl radical $\left({ }^{\circ} \mathrm{OH}\right)$ from hydrogen peroxide $\left(\mathrm{H}_{2} \mathrm{O}_{2}\right)$ at the fiber surface $^{13}$. Moreover, active oxygen species are generated at the surface of silica, especially when freshly crushed ${ }^{14,15}$. Dusts causing pulmonary fibrosis (amosite, chrysotile, and crocidolite asbestos, Min-u-sil-5 silica, kaolin and diatomite) are Fenton catalysts whereas minerals not associated with lung disease (wollastonite, non-fibrous tremolite, and fiberglass) do not display Fenton activity ${ }^{16}$. In addition to the intrinsic ability of minerals to generate active oxygen species by acellular mechanisms, oxygen metabolites are formed after phagocytosis of particulates by inflammatory cells ${ }^{17}$.

Effects of active oxygen species are counterbalanced by an elaborate system of enzymatic and non-enzymatic antioxidants located at specific intracellular and extracellular sites within the lung ${ }^{18}$. Endogenous enzymes involved in the removal of active oxygen species include superoxide dismutase, catalase and glutathione peroxidase (GPX). Little is known about the regulation of antioxidant enzymes (AOE) in rat lung after exposure to mineral dusts and their involvement in lung defense from mineral-induced cell injury. Previously, we have shown that inhalation of asbestos causes increases in enzyme activity of catalase, GPX and total superoxide dismutase ( $\mathrm{CuZn}$ and MnSOD) in rat lung homogenates ${ }^{19}$. Moreover, increases in steady-state mRNA levels of these enzymes were observed in rat lungs after brief inhalation (1 day to 2 weeks) of the fibrogenic minerals, crocidolite asbestos or the silicon dioxide, cristobalite silica $^{20}$. Increases in MnSOD were most dramatic suggesting that gene expression of this AOE could be used as an indicator of acute pulmonary inflammation.

The goal of the present study was to determine if gene expression and immunoreactive protein of $\mathrm{AOE}$ were altered in rat lungs after prolonged inhalation of cristobalite silica or titanium dioxide of two particle sizes $\left(\mathrm{TiO}_{2}-\mathrm{F}\right.$, $250 \mathrm{~nm}$ particle diameter, and ultra-fine $\mathrm{TiO}_{2}-\mathrm{D}, 20 \mathrm{~nm}$ particle diameter) evoking striking differences in lung inflammation and fibrogenicity ${ }^{7}$. Specifically, we were interested in whether changes in steady-state mRNA levels of $\mathrm{MnSOD}$ and immunoreactive protein correlated with the inflammatory and fibrotic potential of minerals and persisted after cessation of exposure to minerals. Results suggest that gene expression of MnSOD may be predictive of lung disease.

\section{Methods}

Exposures: Male Fischer 344 rats, weighing approximately 200-250 grams were exposed to alpha cristobalite $\left(1.3 \mathrm{mg} / \mathrm{m}^{3}\right.$ air $)$ ultra-fine titanium dioxide-Degus- 
sa ( $\mathrm{TiO}_{2}-\mathrm{D}$, anatase form, $20 \mathrm{~nm}$ diameter, $23.5 \mathrm{mg} / \mathrm{m}^{3}$ air) or titanium dioxideFisher ( $\mathrm{TiO}_{2}-\mathrm{F}$, anatase form, $250 \mathrm{~nm}$ diameter, $22.3 \mathrm{mg} / \mathrm{m}^{3}$ air) for $6 \mathrm{hr} / \mathrm{day}, 5$ days/wk for 4, 8 and 12 weeks (Experiment \#1). Cristobalite was obtained from C \& E Mineral Corp., King of Prussia, PA, TiO 2 -D from Degussa AG, Frankfurt am Main, Germany and $\mathrm{TiO}_{2}-\mathrm{F}$ from Fisher Scientific, Springfield, NJ. Cristobalite and $\mathrm{TiO}_{2}$ were aerosolized using a Wright dust feeder, whereas $\mathrm{TiO}_{2}-\mathrm{D}$ was aerosolized using a Jet-O-Mizer (Fluid Energy Processing and Equipment Co., Model OO, Hatfield, PA). The particle characteristics of both $\mathrm{TiO}_{2}$ s have been described previously ${ }^{6}$. Sham control animals were placed in dust-free chambers and handled identically. In an additional experiment (Experiment \#2), sham controls and rats exposed to cristobalite $\left(7-10 \mathrm{mg} / \mathrm{m}^{3}\right.$ air) for $3,6,9$ and 14 days after cessation of a 10 day exposure were lavaged, and RNA isolated as described below for Northem blot analysis of MnSOD mRNA levels.

Preparation of lungs: After 4,8, and 12 weeks of exposure to particulates and 29 weeks after cessation of exposure, rats in Experiment \#1 $(\mathrm{N}=4$ /exposure group/time period) were anaesthetized with an intraperitoneal injection of pentobarbital, the chest was opened, and the lungs were removed. Lungs were lavaged with saline ( 10 washes $\times 5 \mathrm{ml}$ ) using gentle massage. Volumes retrieved by BAL were recorded and not significantly different between groups. After lavage, lungs were flash frozen in liquid nitrogen and stored at $-70^{\circ} \mathrm{C}$ for Northem and Western blot analyses. The lungs of other rats were evaluated for inflammation and pulmonary fibrosis by histopathology at 29 weeks and 1 year after the cessation of exposure after perfusion of lungs by techniques reported previously ${ }^{21}$. In Experiment \#2, rats were killed and lavaged as described above. Lavaged cells were then prepared for Northern blot analyses to examine MnSOD mRNA levels.

Northern Blot Analysis: Total RNA was extracted from lung according to procedures described previously ${ }^{20}$. RNA was fractionated on a $1.0 \%$ agarose, $2.25 \mathrm{M}$ formaldehyde gel in running buffer containing $20 \mathrm{mM} \mathrm{3}$-[N-morpholino]-propanesulfonic acid, $\mathrm{pH} 7.4$, and $1 \mathrm{mM}$ EDTA. After ethidium bromide staining and UV examination of RNA to confirm loading homogeneity, RNA was transferred onto nitrocellulose filters (Schleicher and Shuell, Keene, $\mathrm{NH}$ ). Filters were prehybridized (50\% deionized formamide, $5 \mathrm{X}$ SSC, $5 \mathrm{X}$ Denhardt's solution, $50 \mu \mathrm{g} / \mathrm{ml}$ Salmon testes DNA, $0.1 \%$ sodium dodecyl sulfate) for 8-24 hours and subsequently hybridized with ${ }^{32} \mathrm{P}$-labeled cDNA probes overnight at $42^{\circ} \mathrm{C}$. cDNAs were radiolabeled using a Prime-a-Gene labeling system (Promega, Madison, WI). Filters were washed and visualized by exposure to Kodak X-Omat AR film (Rochester, NY) at $-70^{\circ} \mathrm{C}$ using intensifying screens. Radioactivity on filters was quantitated directly using a Betascope blot analyzer (model 603, version 2, Betagen Corp., Waltham, MA). For MnSOD mRNA analyses, the major $1 \mathrm{~Kb}$ mRNA species was scanned. Rat MnSOD and CuZnSOD cDNA probes were obtained from Y.-S Ho, Wayne 
State University, Detroit, $\mathrm{MI}^{22,23}$. A rat catalase cDNA probe was provided by S. Furata, Shinshu University School of Medicine, Mastumoto, Japan ${ }^{24}$ and a mouse GPX probe from G. Mullenbach, Chiron Corp., Emeryville, $\mathrm{CA}^{25}$. A rat probe for the housekeeping gene, glyceraldehyde-3-phosphate dehydrogenase (GAPDH), was obtained from Dr. Jeanteur, Laboratoire de Biochimie, Centre Paul Lamarque, Montpellier, France ${ }^{26}$.

Western Blot Analysis: Western blot analysis of immunoreactive protein was used to determine if increases in steady-state mRNA levels of AOE resulted in increased translation into protein. Small aliquots of lung tissue were homogenized in phosphate buffer ( $0.05 \mathrm{M}, 1 \mathrm{mM}$ EDTA, pH 7.8) on ice using a Polytron apparatus (Brinkman, Westbury, NY) $(2 \times 60$ seconds at the highest speed) and centrifuged at $14000 \mathrm{rpm}\left(4^{\circ} \mathrm{C}\right)$. Protein content of lung homogenates was assessed according to the method of Bradford ${ }^{27}$. Supernatants were stored at $-70^{\circ} \mathrm{C}$. Homogenates were lyophilized, reconstituted in electrophoresis sample buffer and electrophoresed in 15\% SDS-polyacrylamide gels as described previously ${ }^{28}$. Subsequently, proteins were electrotransferred onto nitrocellulose using a semi-dry electroblotter (Kirkegaard and Perry, Gaithersburg, MD). Blots were stored at $4^{\circ} \mathrm{C}$ in PBS until analysis. Non-specific binding was blocked by incubating blots for 30 minutes in PBS-Tween $(.05 \%)$. Subsequently blots were incubated with primary antibody for 1 hour. Antihuman kidney MnSOD, anti-bovine catalase and anti-human GPX antibodies, were generously provided by Dr. L. W. Oberley, University of Iowa, Iowa City, $\mathrm{IA}^{29}$. Anti-rat CuZnSOD was a gift from Dr. D. M. Massaro, Georgetown University, Washington, DC $^{30}$. Blots were washed with PBS-Tween $(3 \times 4$ minutes) and incubated with biotinylated secondary antibodies (Vector laboratories, Burlingame $\mathrm{CA}$ ) for 1 hour. Protein bands were visualized with a Vectastain $\mathrm{ABC}$ kit (Vector Laboratories, Burlingame, $\mathrm{CA}$ ). In order to assess loading homogeneity after protein transfer, gels were stained with Coomassie blue.

Differential and total cell counts in bronchoalveolar lavage (BAL): Lavaged cells from lungs were centrifuged at $1500 \mathrm{rpm}$ for 10 minutes at $4^{\circ} \mathrm{C}$, and the cells were counted using a hemocytometer as described previously ${ }^{21}$. Cytospin slides were prepared and stained with Diff-Quick (Baxter Scientific, Bedford, MA). Differential cell counts were obtained by counting at least 500 cells per slide on 2 slides per animal.

Statistics: Raw data were evaluated by analysis of variance, with correction for multiple comparisons (Duncan procedure). Correlations between inflammatory response (cell totals and differentials in BAL) and MnSOD mRNA expression of combined groups were computed using Pearson correlation analysis. 


\section{Results}

Gene expression of antioxidant enzymes (AOE): Figure 1 shows steady-state levels of mRNA for AOE in rat lungs after inhalation of particles. In addition to MnSOD, we evaluated message levels of CuZnSOD, catalase and GPX to indicate whether trends in expression were observed. For MnSOD, at least 5 species of mRNA were present in rat lung (Figure 2), as has been reported in human lung ${ }^{31}$. Since the $1 \mathrm{~Kb}$ species of MnSOD is most abundant, its quantitation is shown here. Quantitation of the $4 \mathrm{~Kb}$ mRNA species also exhibited similar trends in expression in our studies (not shown).

Inhalation of the highly inflammatory and fibrogenic silica, cristobalite, caused dramatic increases in MnSOD mRNA levels in rat lung, which were significantly elevated at all time periods $(p<.05)$. However, steady-state mRNA levels of the other AOE after inhalation of cristobalite were variable (Figure 1). Lung catalase mRNA levels were decreased at 4 and 12 weeks after inhalation

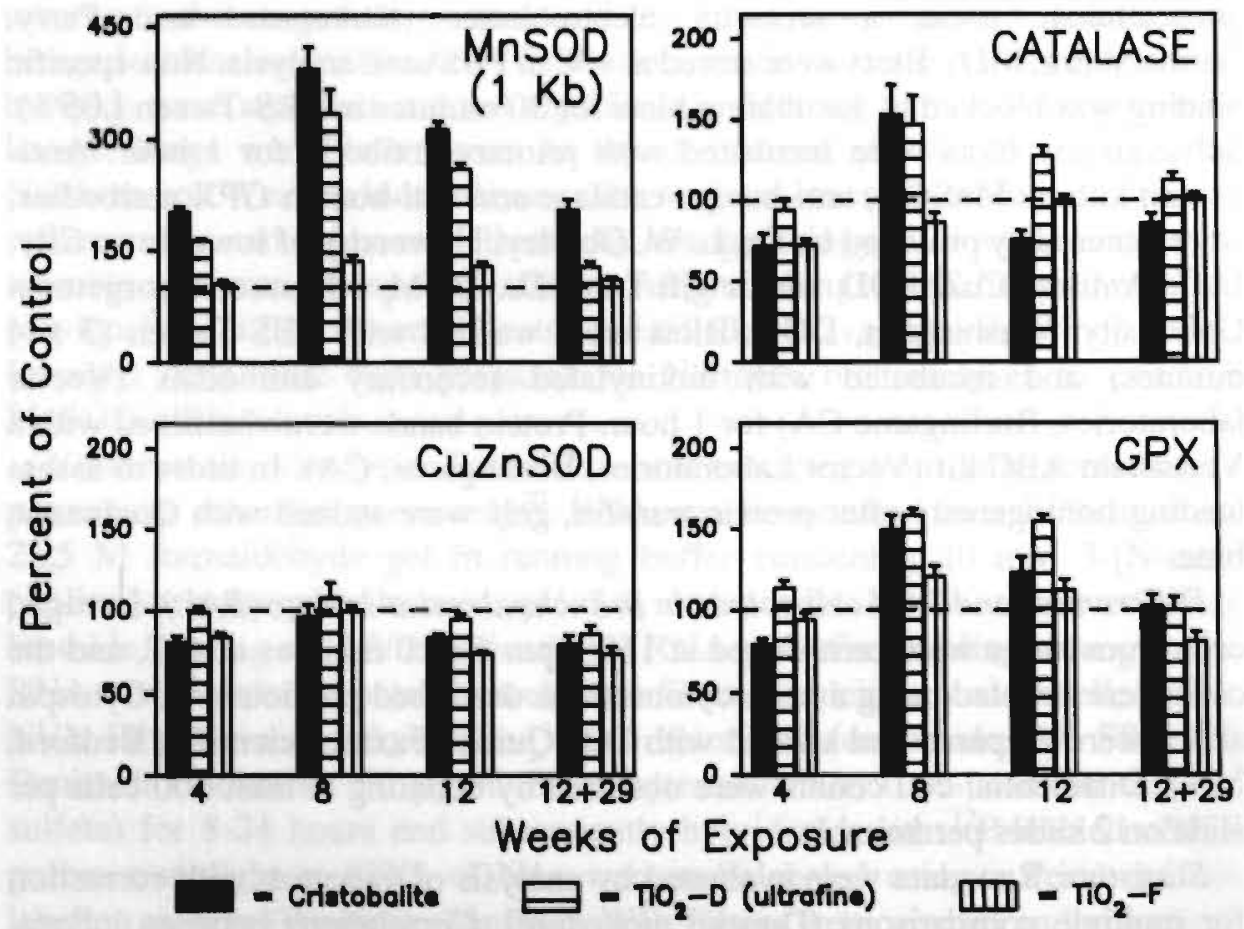

Figure 1: Steady-state mRNA levels of AOE in rat lung at 4, 8 , and 12 weeks of inhalation of mineral dusts and at 29 weeks after cessation of the exposure. Results are expressed as mean percentages $( \pm S E M)$ of sham controls $(N=4$ rats/exposure group/time period). Data were quantitated from Betascope blot analysis. For MnSOD, the $1 \mathrm{~Kb}$ band was quantitated. Note the differences in scale between the ordinates of panel I (MnSOD) and the other panels. 
MnsoD

A.
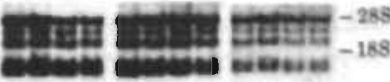

B.

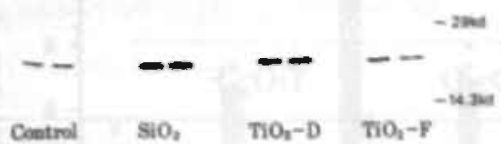

CuZnSOD

A.

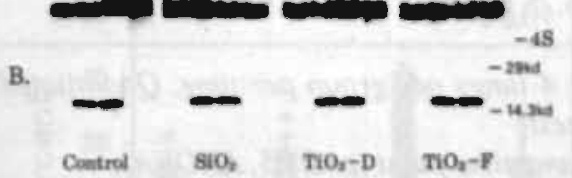

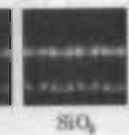
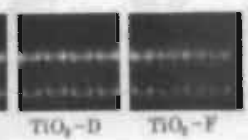

Figure 2: Northern and Western blot analyses of AOE after 8 weeks of mineral dust inhalation. A: Northern blots. $15 \mu \mathrm{g}$ of RNA extracted from lung was electrophoresed, transferred onto nitrocellulose and hybridized to ${ }^{32} P$-labeled $c D N A$ probes specific for the $A O E$ as described. The locations of $28 S$ and $18 S$ ribosomal RNA bands are indicated by horizontal lines. The $1 \mathrm{~Kb}$ mRNA species of MnSOD is indicated by arrow. B: Western blots. Protein from homogenized rat lung was electrophoresed on $15 \%$ acrylamide gels, electrotransferred onto nitrocellulose and incubated with antibodies specific for the various $A O E$ as described in the Methods section. The following amounts of total protein were applied per lane; for MnSOD and catalase, $40 \mu \mathrm{g} ; C \mathrm{ZnNSOD}, 10 \mu \mathrm{g}$; and $50 \mu \mathrm{g}$ for GPX. Locations of prestained low molecular weight standards are indicated. C: Ethidium bromide staining of RNA on agarose-formaldehyde gels to confirm loading homogeneity.

of cristobalite. However, after 8 weeks, steady-state catalase mRNA was increased $(p<.05)$. An early decrease in GPX mRNA levels was observed in cristobalite-exposed animals, but significant increases $(p<.05)$ in lung GPX mRNA levels were observed at 8 and 12 weeks. After inhalation of cristobalite, levels of CuZnSOD mRNA levels were decreased or unchanged.

Like cristobalite, inhalation of fibrogenic ultrafine $\mathrm{TiO}_{2}$-D caused consistent and dramatic increases $(p<.05)$ in MnSOD mRNA expression in rat lung. $\mathrm{TiO}_{2}$-D caused significant increases in steady-state mRNA levels of catalase and GPX after 8 and 12 weeks of exposure ( $p<.05$ ), whereas CuZnSOD mRNA expression remained unchanged or slightly decreased. After inhalation of non- 
Table 1. Steady-state mRNA levels of glyceraldehyde-3-phosphate dehydrogenase (GAPDH) in rat lung homogenates.

\begin{tabular}{|c|c|c|c|c|}
\hline \multirow{2}{*}{$\begin{array}{l}\text { Weeks of } \\
\text { Exposure }\end{array}$} & \multicolumn{4}{|l|}{ GAPDH $^{2}$} \\
\hline & Sham & Cristobalite & $\mathrm{TiO}_{2}-\mathrm{D}$ & $\mathrm{TiO}_{2}-\mathrm{F}$ \\
\hline 4 & $6.65 \pm 0.34$ & $7.48 \pm 0.20$ & $7.45 \pm 0.38$ & $7.30 \pm 0.24$ \\
\hline 8 & $6.23 \pm 0.47$ & $9.53 \pm 0.64^{b}$ & $9.30 \pm 0.65^{b}$ & $6.30 \pm 0.16$ \\
\hline 12 & $8.85 \pm 1.0$ & $11.35 \pm 0.44^{b}$ & $15.05 \pm 0.76^{b}$ & $12.1 \pm 0.52^{b}$ \\
\hline $12+29$ & $5.73 \pm 0.24$ & $6.23 \pm 0.41$ & $5.75 \pm 0.13$ & $5.03 \pm 0.15$ \\
\hline
\end{tabular}

a Counts per minute (cpm) (Mean \pm S.E.M.) per 4 lungs per group per time. Quantitated using a Betascope apparaius as described in the text.

b Significantly different from sham group at the same time point $(p<0.05$, ANOVA).

Table 2. Steady-state mRNA levels of Manganese-containing superoxide dismutase (MnSOD) in cells obtained from bronchoalveolar lavage of rats exposed to cristobalite silica.

\begin{tabular}{llc}
\hline & \multicolumn{2}{l}{ MnSOD $^{\mathrm{a}}$} \\
\cline { 2 - 3 } Days of Exposure & Sham & Cristobalite \\
\hline 3 & $8.85 \pm 0.35$ & $8.8 \pm 1$ \\
6 & $8.15 \pm 0.25$ & $11.8 \pm 0.4^{\mathrm{b}}$ \\
9 & $4.4 \pm 1.4$ & $8.4 \pm 0.8^{\mathrm{b}}$ \\
$10 \& 14$ & $4.0 \pm 0.5$ & $9.5 \pm 0.4^{\mathrm{b}}$ \\
\hline
\end{tabular}

${ }^{a}$ Counts per minute (cpm) (Mean \pm S.E.M.) per 4 lungs per group per time. Quantitated using a Betascope apparatus as described in the text.

bignificantly different from sham group at the same time point ( $p<0.05$, ANOVA).

fibrogenic $\mathrm{TiO}_{2}-\mathrm{F}$, only minimal increases in MnSOD and GPX mRNA levels occurred, and catalase and CuZnSOD mRNA expression in lung were unchanged or decreased at various time points. Use of the "housekeeping" gene, GAPDH, provided surprising results in that significant increases were observed in mineral-exposed lungs, but not sham controls, at 8 and 12 weeks (Table 1). Thus, it appeared to be an inappropriate housekeeping gene for these studies. Ethidium bromide staining of RNA indicated that loading of gels was equivalent (Figure 2c).

Table 2 shows steady-state mRNA levels of MnSOD in BAL cells from rats after short-term exposure to cristobalite. In comparison to sham rats, gene 

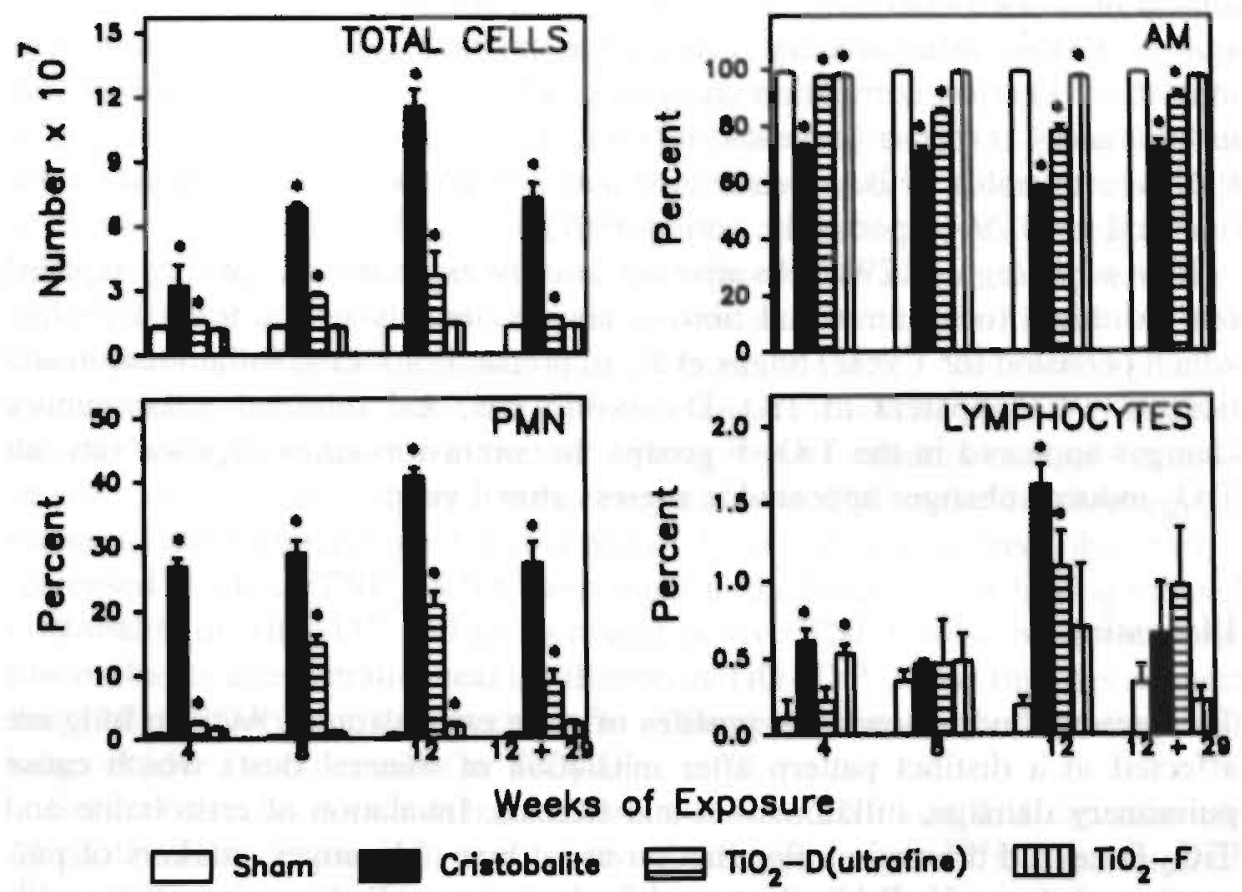

Figure 3: Total cell numbers and differential cell counts in BAL after 4,8 and 12 weeks of inhalation of mineral dusts and at 29 weeks after cessation of exposure. Results are means \pm SEM of $N=4$ rats/ exposure group/time period. ${ }^{*} p<0.05$ (ANOVA).

expression in cristobalite-exposed animals was increased $(p<.05)$ as early as 6 days after initiation of exposure.

Immunoreactive protein: Figure 2 shows results of Northern and Western blot analyses of $\mathrm{AOE}$ in rat lung after 8 weeks of inhalation of particles, the time period where increases in MnSOD were most striking. Results show that the increases in steady-state levels of MnSOD mRNA observed after exposure to cristobalite or $\mathrm{TiO}_{2}$-D correlate directly with increases in MnSOD immunoreactive protein in the lungs of these animals. Although increases in mRNA levels of catalase and GPX also occurred at this time period (Figure 1), dramatic differences in levels of these immunoreactive proteins were not observed in Western blots. No significant changes in CuZnSOD mRNA expression were observed in rat lungs (Figure 1). These findings correlate with CuZnSOD protein levels which remained unchanged as well after mineral exposure (Figure 2).

Total and differential cell counts: Figure 3 shows total and differential cell counts in BAL after inhalation of particulates. Both cristobalite and $\mathrm{TiO}_{2}-\mathrm{D}$ 
inhalation caused marked increases in total cell numbers and increased percentages of PMNs. Inflammatory responses were most striking after cristobalite inhalation. Pearson correlation analysis of all groups showed that the overall inflammatory response (indicated by total cell numbers and the percentage of PMNs recoverable by BAL) correlated with mRNA expression of MnSOD ( $\mathrm{r}=$ 0.68 and $r=0.79$, respectively, both $p<0.01$ ).

Histopathology: At 29 weeks after cessation of exposure, cristobalite-exposed rats exhibited focal interstitial fibrosis and moderately severe focal alveolitis which persisted for 1 year (Baggs et al., in preparation). Less inflammation and fibrosis were apparent in $\mathrm{TiO}_{2}$-D-exposed rats, and minimal inflammatory changes appeared in the $\mathrm{TiO}_{2}-\mathrm{F}$ groups. In contrast to silica-exposed rats, all $\mathrm{TiO}_{2}$-induced changes appeared to regress after 1 year.

\section{Discussion}

The present study shows that profiles of gene expression of AOE in lung are affected in a distinct pattern after inhalation of mineral dusts which cause pulmonary damage, inflammation and fibrosis. Inhalation of cristobalite and $\mathrm{TiO}_{2}-\mathrm{D}$ caused dramatic inflammation in rat lung. Moreover, markers of pulmonary damage in BAL (lactate dehydrogenase, alkaline phosphatase, $\beta$ glucuronidase) were increased after exposure to cristobalite and $\mathrm{TiO}_{2}-\mathrm{D}$, and increased collagen deposition and pulmonary fibrosis were observed at later time periods ${ }^{32}$. We demonstrate here that cristobalite and ultra-fine $\mathrm{TiO}_{2}-\mathrm{D}$ also cause dramatic increases in steady-state MnSOD mRNA expression in lung which remained elevated 29 weeks after cessation of the exposure period. Increased MnSOD mRNA expression was accompanied by increases in levels of immunoreactive protein. In contrast, mRNA levels of other AOE in lungs appeared to be affected differently after inhalation of mineral dusts. Small increases in mRNA expression of catalase and GPX were observed in rat lungs after inhalation of cristobalite or ultra-fine $\mathrm{TiO}_{2}-\mathrm{D}$, but not after exposure to $\mathrm{TiO}_{2}-\mathrm{F}$. In contrast, $\mathrm{CuZnSOD}$ levels remained unchanged or were slightly decreased in rat lungs after exposure to the various mineral dusts.

Unique to our present study was the use of particulates eliciting different patterns and magnitudes of pulmonary inflammation as indicated by inflammatory cell infiltrates in BAL. Statistical analysis showed a direct correlation between increases mRNA expression of MnSOD and the inflammatory potential of the mineral dusts determined by differential and total cell counts in BAL and confirmed by histopathology.

Whether inflammatory and fibrogenic minerals directly cause elevation of MnSOD at the level of gene expression or do so via elaboration of cytokines by cells of the immune system is unclear. Several cytokines such as tumor necrosis 
factor $\alpha$ (TNF) and interleukin 1 (IL-1) are able to modulate the induction of $\mathrm{AOE}$ directly. Moreover, both cytokines are released by inflammatory cells in response to specific stimuli including mineral dusts ${ }^{33-35}$. For example, Driscoll et al showed increased TNF release by AMs exposed to Min-U-Sil in vitro or after intratracheal administration of silica of $\mathrm{TiO}_{2}$ to rats ${ }^{34}$. Moreover, Borm et al. showed increased TNF release by peripheral blood monocytes of coal miners with or without lung abnormalities when compared to non-dust exposed controls $^{33}$. Recently, Piquet and coworkers demonstrated that antibody to TNF could prevent silica-induced pulmonary fibrosis in mice ${ }^{36}$. Alternatively, concomitant administration of TNF with instillation of silica resulted in an augmented collagen deposition in the mouse lung when compared to administration of silica alone. This study indicates a causal role of TNF in the development of mineral-induced lung disease. In support of these findings, we have observed: i) increased levels of TNF mRNA expression in the lungs of rats having inhaled cristobalite or $\mathrm{TiO}_{2}-\mathrm{D}^{37}$ and ii) increased in vivo TNF release by rat alveolar macrophages after intratracheal instillation of $\mathrm{TiO}_{2}-\mathrm{D}^{38}$. These findings suggest that TNF is involved in the development of lung inflammation and fibrosis in rat lungs exposed to cristobalite or $\mathrm{TiO}_{2}-\mathrm{D}$.

Several investigators also have shown that both TNF and IL- 1 can increase MnSOD mRNA expression in a variety of cell type in vitro ${ }^{39-42}$. Expression of other AOE remains unaffected after exposure to these cytokines. Since mRNA levels of TNF were increased in cristobalite- and $\mathrm{TiO}_{2}$-D-exposed rat lungs at timepoints showing increased MnSOD mRNA expression ${ }^{37}$, this cytokine might be responsible for the increases in MnSOD mRNA expression observed in experiments here.

Because our studies on $\mathrm{AOE}$ gene expression were performed on lavaged lung tissue, increases in MnSOD mRNA did not reflect the contributions of AMs and other cells in the airspaces. In recent studies, we have demonstrated using ultrastructural immunocytochemistry and morphometry, significant increases in amounts of MnSOD protein in mitochondria of type II pneumocytes after inhalation of cristobalite ${ }^{43}$. Little immunodetectable MnSOD was found in type I pneumocytes, fibroblasts, PMNs or endothelial cells. Thus, increases in MnSOD gene expression and protein levels appear to be primarily reflected by induction of protein by type II epithelial cells in the lung. However, TNF or other cytokines released from AMs and other cells of the immune system in the airspaces or interstitium may modulate these increases.

Short-term inhalation studies using cristobalite indicate that MnSOD mRNA levels increase in the lung ${ }^{20}$ as well as in cells retrieved from BAL as early as 6 days after initiation of exposure (Table 2). Moreover, gene expression of MnSOD remains elevated in both BAL cells and lung after cessation of exposure to dust and during the progression of mineral-induced fibrosis. The results of these experiments are exciting as BAL is a relatively noninvasive technique used 
in the diagnosis of pulmonary disease in clinical research. It is conceivable, based upon results here, that elevated message levels of MnSOD in BAL may be predictive of mineral-induced inflammation and pulmonary fibrosis in man.

\section{Acknowledgements}

The authors thank Judith Kessler, Nancy Corson, Pamela Mercer and Kiem Nguwen for their technical assistance, and Barb Cady and Rhoda Rowell for preparing the manuscript.

Supported by NIH grants ES 04872 (G. Oberdörster), HL 39469 (B.T. Mossman), and a grant from the EPA (B.T. Mossman). 


\section{REFERENCES}

1. Craighead, J.E.; Kleinerman, J.; Abraham, L.; Gibbs, R.; Green, H.Y.; Harley, R.A.; Ruettner, J.R.; Vallyathan, N.V.; Juliano, E.B. Diseases associated with exposure to silica and nonfibrous silicate minerals. Arch. Pathol. Lab. Med. 112:673-720; 1988.

2. Absher, M.P.; Trombley, L.; Hemenway, D.R.; Michey, R.M.; Leslie, K.O. Biphasic cellular and tissue response of rat lungs after eight-day aerosol exposure to the silicon dioxide cristobalite. Am. J. Pathol. 134:1243-1251;1989.

3. Ferin, J.; Oberdörster, G. Biological effects and toxicity assessment of titanium dioxides:Anatase and rutile. Am. Ind. Hyg. Assoc. J. 46:69-72;1985.

4. Lindenschmidt, R.C.; Driscoll, K.E.; Perkins, M.A.; Higgins, J.M.; Maurer, J.K.; Be]fiore, K.A. The comparison of a fibrogenic and two nonfibrogenic dusts by bronchoalveolar lavage. Tox. Appl. Pharmacol. 102:268-81;1990.

5. Driscoll, K.E.; Maurer, J.K.; Lindenschmidt, R.C.; Romberger, D.; Rennard, S.I.; Crosby, L. Respiratory tract responses to dust: Relationships between dust burden, lung injury, alveolar macrophage fibronectin release, and the development of pulmonary fibrosis. Toxicol. Appl. Pharm. 106:88-101;1990.

6. Ferin, J.; Oberdörster, G.; Soderholm, S.C.; Gelein, R. Pulmonary tissue access of ultrafine particles. J. Aerosol Med. 4:57-68;1991.

7. Oberdörster, G.; Ferin, J.; Gelein, R.; Soderholm, S.C.; Finkelstein, J. Role of the alveolar macrophage in lung injury. Studies with ultrafine particles. Env Health Perspect. (In Press).

8. Kamp, D.W.; Graceffa, P.; Pryor, W.A.; Weitzman, S.A. The role of free radicals in asbestos-induced diseases. Free Rad. Biol. Med. 12:293-315;1992.

9. Goodlick, L.A.; Kane, A.B. Role of reactive oxygen metabolites in crocidolite asbestos toxicity to mouse macrophages. Cancer Res. 46:5558-66; 1986.

10. Mossman, B.T.; Marsh, J.P.; Shatos, M.A. Alternation of superoxide dismutase (SOD) activity in tracheal epithelial cells by asbestos and inhibition of cytotoxicity by antioxidants. Lab. Invest. 54:204-212;1986.

11. Shatos, M.A.; Doherty, J.M.; Marsh, J.P.; Mossman, B.T. Prevention of asbestos-induced cell death in rat lung fibroblasts and alveolar macrophages by scavengers of active oxygen species. Environ. Res. 44:103-116;1987.

12. Voisin, C.; Aerts, C.; Wallaert, B. Prevention of in vitro oxidant mediated alveolar macrophage injury by cellular glutathione and precursors. Clin. Resp. Physiol. 23:309$313 ; 1987$.

13. Weitzman, S.A.; Graceffa, P. Asbestos catalyses hydroxyl and superoxide radical generation from hydrogen peroxide. Arch. Biochem. Biophys. 228:373-376; 1984.

14. Dalal, N.S.; Shi, X.; Vallyathan, V. Potential role of silicon-oxygen radicals in acute lung injury. In: Mossman BT, Begin RO, eds. Effects of mineral dusts on cells. Berlin: Springer-Verlag, 1989:265-272.

15. Fubini, B.; Bolis, V.; Giamello, E.; Pugliese, L.; Volante, M. The formation of oxygen reactive radicals at the surface of crushed quartz dusts as a possible cause of silica pathogenecity. In: Mossman, B.T.; Begin, R.O., eds. Effects of mineral dusts on cells. Berlin: Springer-Verlag, 1989:205-214.

16. Kennedy, T.P.; Dodson, R.; Rao, N.V.; Ky, H.; Hopkins, C.; Baser, M.; Tolley, E.; Hoidal, J.R. Dusts causing pneumoconiosis generate $\mathrm{OH}^{\bullet}$ and produce hemolysis by acting as Fenton catalysts. Arch. Biochem. Biophys. 269:359-364;1989. 
17. Hansen, K.; Mossman, B.T. Generation of superoxide $\left(\mathrm{O}_{2}^{\bar{\gamma}}\right)$ from alveolar macrophages exposed to asbestiform and nonfibrous particles. Cancer R'es. 47:1681-1686;1987.

18. Heffner, J.E.; Repine, J.E. Pulmonary strategies of antioxidant defense. Am. Rev. Respir. Dis. 140:531-554;1989.

19. Janssen, Y.M.W.; Marsh, J.P.; Absher, M.; Borm, P.J.A.; Mossman, B.T. Increases in endogenous antioxidant enzymes during asbestos inhalation in rats. Free Rad. Res. Comms. 11:53-58; 1990.

20. Janssen, Y.M.W.; Marsh, J.P.; Absher, M.; Hemenway, D.; Vacek, P.; Leslie, K.C.L.; Borm, P.J.A; Mossman, B.T. Expression of antioxidant enzymes in rat lungs after inhalation of asbestos or silica. J. Biol. Chem. 267:10625-10630;1992.

21. Mossman, B.T.; Marsh, J.P. „ Gilbert, R.; Hardwick, D.; Sesko, A.; Hill, S.; Shatos, M.A.; Doherty, J.; Bergeron, M.; Adler, K.B.; Hemenway, D.; Mickey, R.; Vacek, P.; Kagan. E. Inhibition of lung injury inflammation and interstitial pulmonary fibrosis by polyethylene glycol-conjugated catalase in rats exposed by inhalation to asbestos. Am. Rev. Respir. Dis. 141:1266-1271;1990.

22. Ho Y.S.; Crapo, J.D. cDNA and deduced amino acid sequence of rat copper-zinc-containing superoxide dismutase. Nucl. Acids Res. 15:6746;1987.

23. Ho Y.S.; Crapo, J.D. Nucleotide sequences of cDNA's coding for rat manganese-containing superoxide dismutase. Nucl. Acids Res. 15;10070;1987.

24. Furata S.; Hayashi, H.; Hijikata, M.; Miyazawa, S.; Osumi, T.; Hashimoto, T. Complete nucleotide sequence of CDNA and deduced amino acid sequence of rat liver catalase. Proc. Natl. Acad. Sci. USA 83:313-7;1986.

25. Mullenbach G.T.; Tabrizi, A.; Irvine, B.D.; Bell, G.I.; Tainer, J.A.; Hallewell, R.A. 5DNAs of three glutathione peroxidases: selenocysteine incorporation. In: Cerutti, P.A.; Fridovich, I.; McCord, J.M.; Alan, R. eds. Oxy-radicals in molecular biology and pathology. Liss, Inc. New York, 1988;313-26.

26. Piechaczyk, M.; Blanchard, J.M.; Marty, L.; Dani, Ch.; Panabieres, F.; Sabouty, S.El.; Fort, Ph.; Jeanteur, Ph. Post-transcriptional regulation of glyceraldehyde-3-phosphatedehydrogenase gene expression in rat tissues. Nucleic Acids Res. 12:6951-6963;1984.

27. Bradford M.N. A rapid sensitive method for the quantitation of microgram quantities of protein utilizing the principal of protein-dye binding. Anal. Biochem. 72:248-54;1076.

28. Edmondson S.W.; Wu, R.; Mossman, B.T. Regulation of differentiation and keratin protein expression by vitamin $\mathrm{A}$ in primary cultures of hamster tracheal epithelial cells. J. Cell. Physiol. 142:21-30;1990.

29. Oberley T.D.; Oberley, L.W.; Slattery, A.F.; Lauchner, L.J.; Elwell, J.H. Immunohistochemical localization of antioxidant enzymes in adult syrian hamster tissues and during kidney development. Am. J. Path. 137:199-214;1990.

30. Hass M.A.; Frank, L.; Massaro, D. The effect of bacterial endotoxin on synthesis of $(\mathrm{Cu}, \mathrm{Zn})$ superoxide dismutase in lungs of oxygen-exposed rats. J. Biol. Chem. 257:9379$83 ; 1982$.

31. Wispe, J.R.; Clark, J.C.; Burhans, M.S.; Kropp, K.E.; Korfhagen, T.R.; Whitsett, J.A. Synthesis and processing of the precursor for human mangano-superoxide dismutase. Biochim. Biophys. Acta 994:30-36;1989.

32. Oberdörster G.; Ferin, J.; Soderholm, S; Gelein, R.; Cox, C.; Baggs, R.; Morrow, P. Increased pulmonary toxicity of inhaled ultrafine particles: due to lung overload alone? Proceedings, Seventh International Symposium on Inhaled Particles. Ann. Occup. Healih. In Press. 
33. Borm P.J.A.; Palmen, N.; Engelen, J.J.M.; Buurman, W.A. Spontaneous and stimulated release of Tumor Necrosis Factor-Alpha (TNF) from blood monocytes of miners with Coal Workers' Pneumoconiosis. Am. Rev. Respir. Dis. 138:1589-94;1988.

34. Driscoll K.E.; Lindenschmidt, R.C.; Maurer, J.K; Higgins, J.M. Release of Interleukin 1 and Tumor Necrosis Factor by rat alveolar macrophages after in vitro exposure to mineral dusts. In: Mossman, B.T.; Begin, R.O., eds. Effects of mineral dusts on cells. NATO ASI series., vol H30. Berlin Heidelberg: Springer-Verlag; 1989:101-8.

35. Dubois, C.; Bissonnette, E.; Pleszczynski, M.R. Leukotriene B4 and Tumor Necrosis Factor production after in vitro exposure of rat alveolar macrophages to mineral dust: Potential role in fibrogenesis. In: Mossman, B.T.; Begin, R.O. eds. Effects of mineral dusts on cells. NATO ASI series. Vol H30. Berlin Heidelberg: Springer-Verlag; 1989;359-66.

36. Piquet P.F.; Kollart, M.A.; Grau, G.E.; Sappino, A.P.; Vassalli, P. Requirement of tumour necrosis factor for development of silica-induced pulmonary fibrosis. Nature 344:245-7;1990.

37. Driscoll, K.E.; Strzelecki, J.; Hassenbein, D.; Janssen, Y.M.W.; Marsh, J.; Oberdorster, G.; Mossman, B.T. Tumor necrosis factor (TNF): Evidence for the role of TNF in increased expression of manganese superoxide dismutase after inhalation of mineral dusts. Proceedings, Seventh International Symposium on Inhaled Particles. Ann. Occup. Hyg. In Press.

38. Driscoll K.E.; Maurer, J.K. Cytokine and growth factor release by alveolar macrophages: potential biomarkers of pulmonary toxicity. Tox. Path. In Press.

39. Masuda, A.; Longo, D.L.; Kobayashi, Y.; Appella, E.; Oppenheim, J.J.; Matsushima, K. Induction of mitochondrial manganese superoxide dismutase by Interleukin 1. FASEB J. 2:3087-91;1988.

40. Shaffer J.B.; Treanor, C.P.; Del Vecchio. P.J. Expression of bovine and mouse endothelial cell antioxidant enzymes following TNF-alpha exposure. Free. Rad. Biol. Med. 8:497-502;1990.

41. Visner, G.A.; Dougall, W.C.; Wilson, J.M; Burr, I.A.; Nick, H.S. Regulation of manganese superoxide dismutase by lipopolysaccharide, interleukin 1 and tumor necrosis factor. J. Biol. Chem. 265:2856-2864;1990.

42. Wong, G.H.W.; Goeddel, D.V. Induction of manganous superoxide dismutase by Tumor Necrosis Factor: Possible protective mechanism. Science. 242:941 -44;1988.

43. Holley J.A.; Janssen, Y.M.W.; Mossman, B.T.; Taatjes, D. Increased manganese superoxide dismutase protein in Type II epithelial cells of rat lungs after inhalation of crocidolite asbestos or cristobalite silica Am. J. Path. 141:475-48.5; 1992. 


\section{Oxidant Stress Responses in Human Pleural Mesothelial Cells Exposed to Asbestos and Xanthine/ Xanthine Oxidase}

Y.M.W. Janssen * , J.P. Marsh", M.P. Absher", E. Gabrielson", P.J.A. Borm ${ }^{\dagger}$, K. Driscoll ${ }^{1}$, and B.T. Mossman".

Departments of Pathology ${ }^{*}$ and Medicine ${ }^{\ddagger}$, University of Vermont, Medical Alumni Building, Burlington VT, 05405 U.S.A.

${ }^{\dagger}$ Department of Health Risk Analysis and Toxicology, University of Limburg, Maastricht, The Netherlands

I"Procter and Gamble, Miami Valley Laboratories, Cincinnati OH, ${ }^{8}$ Department of Pathology, Johns Hopkins School of Medicine, Baltimore MD. 


\section{Summary}

Generation of oxidants is a proposed mechanism of cell injury by asbestos fibers. To determine if human pleural mesothelial cells (HMC) responded to asbestos and active oxygen species (AOS) by induction of antioxidant enzymes, cells obtained from pleural effusion were exposed to crocidolite or chrysotile asbestos or xanthine/xanthine oxidase (X/XO), a chemical generating system of AOS. Gene expression of manganese-containing superoxide dismutase (MnSOD) and heme oxygenase (HO), endogenous enzymes involved in cell defense against oxidant stresses, was then determined. Dosage-dependent increases in steady-state mRNA levels of MnSOD and HO were observed in HMC exposed to asbestos or $\mathrm{X} / \mathrm{XO}$. However, increases in gene expression of MnSOD or HO did not occur in HMC after exposure to particulates such as polystyrene beads or riebeckite, the nonfibrous analog of crocidolite asbestos. Comparative experiments with human adult lung fibroblasts (HAL), showed less striking increases in mRNA levels of $\mathrm{MnSOD}$ and $\mathrm{HO}$ in response to asbestos, but steady-state mRNA levels for $\mathrm{HO}$ were increased more than 5 fold in response to X/XO. To determine if increases in mRNA levels of MnSOD were translated into protein, Western blot analyses were performed on HMC and HAL cells exposed to asbestos or X/XO. Slight increases in MnSOD immunoreactive protein were observed in HMC in response to both agents. In contrast, $\mathrm{X} / \mathrm{XO}$ caused striking elevations in MnSOD protein levels in HAL cells. These results suggest that certain antioxidant enzymes are inducible in $\mathrm{HMC}$ after exposure to asbestos and other oxidants.

\section{Introduction}

Occupational exposure to asbestos is associated with the development of bronchogenic carcinoma and diseases of the pleura including malignant mesothelioma, pleural plaques and effusions (1). Although the pathogenesis of asbestos-related diseases is complex, a number of studies suggest that active oxygen species (AOS) may mediate asbestos-induced cytotoxicity (2-4), cell proliferation (5) and inflammation (6,7). Administration of antioxidant enzymes to rats during inhalation of asbestos ameliorates lung injury and pulmonary fibrosis normally developing in these animals, an indication that AOS are intrinsic to pulmonary disease (8). Presumably, AOS are generated in the lung or pleura after exposure to asbestos by several mechanisms. Redox reactions driven by iron on the surface of the fibers may result in chronic generation of AOS at sites of fiber deposition $(9,10)$. AOS may also be produced during a respiratory burst by alveolar macrophages (AMs) and neutrophils after unsuccessful phagocytosis of long fibers $(11,12)$. In addition, inflammatory reactions 
occurring after exposure to asbestos may result in chronic generation of AOS in the lung or pleural space (reviewed in 13).

Colony forming efficiency assays using human pleural mesothelial cells (HMC) in vitro indicate that these cell types are much more sensitive to the cytotoxic effects of asbestos than human bronchial epithelial cells and human lung fibroblasts (14). One plausible explanation is that HMC are compromised in their defensive responses to asbestos fibers or other oxidants. The influx of neutrophils into the pleural space and a host of cellular immune responses appear to be involved in the pathogenesis of many pleural diseases (15). Since, AOS may be released in large quantities into the pleural space as a consequence of these processes, antioxidant defenses of mesothelial cells may be essential to the prevention of cell damage and the development of pleural disease. As emphasized at a recent workshop (15), little is known about the ability of the human pleural mesothelial cell to sustain oxidative injury and/or adapt to oxidative stress.

In studies here, we examined the ability of HMC to respond to oxidant stress at the level of gene expression using cDNAs encoding the antioxidant enzymes manganese-containing superoxide dismutase $(\mathrm{MnSOD})$ and heme oxygenase (HO) a gene induced by oxidants in a number of mammalian cell types and implicated in cell defense against oxidative damage (16-18). The purpose of the work was to determine if genes encoding these enzymes are inducible in mesothelial cells. An available antibody recognizing MnSOD protein (19) allowed us to assess by Western blot analysis whether or not increased message levels were translated into immunoreactive protein. Lastly, we used human adult lung fibroblasts (HAL) to assess whether another human cell type responded similarly to asbestos and xanthine plus xanthine oxidase (X/XO), a well-characterized chemical generating system of AOS producing a spectrum of reactive species including superoxide and hydrogen peroxide (20).

\section{Methods}

Chemicals and asbestos: Xanthine and xanthine oxidase were obtained from Calbiochem (La Jolla, CA), fetal bovine serum from Hyclone Laboratories Inc. (Logan UT), phenol from Anachemia (Rouses Point, NY), chloroform from Fisher, and $\left[\alpha-{ }^{32} \mathrm{P}\right] \mathrm{dATP}(3000 \mathrm{Ci} / \mathrm{mmol})$ from Dupont-New England Nuclear. $\mathrm{Ca}^{2+} \mathrm{Mg}^{2+}$-free phosphate-buffered saline (CMFPBS), prestained, low range, protein molecular weight standards, and penicillin/streptomycin were from GIBCO. Bio-Rad dye reagent, acrylamide, bis, ammonium persulfate, TEMED, tris, glycine, Tween-20, and Coomassie Blue stain were all from Bio-Rad (Hercules CA). All other chemicals or growth factors were purchased from Sigma (St. Louis MO). Union Internationale Contre le Cancer (UICC) reference 
samples of crocidolite and chrysotile were used here and characterized previously (5). Nonasbestos particles including riebeckite, a nonfibrous particle chemically similar to crocidolite (21) and polystyrene beads (Polysciences Inc., Warrington, PA) were used as negative controls.

Cell culture and treatment: Two isolates of human mesothelial cells (HMC 9015 and 9017) and a line of human adult lung fibroblasts (HAL) were grown in monolayers at $37^{\circ} \mathrm{C}$ and a $95 \%$ air- $5 \% \mathrm{CO}_{2}$ environment. $\mathrm{HMC}$ were obtained from patients with congestive heart failure and no clinical history of pleural disease by pleural effusion and were maintained in M199 (GIBCO) containing $50 \mathrm{U} / \mathrm{ml}$ penicillin, $50 \mu \mathrm{g} / \mathrm{ml}$ streptomycin, $10 \%$ fetal bovine serum, and 100 $\mathrm{ng} / \mathrm{ml}$ hydrocortisone. HMC were evaluated after $<5$ passages and characterized for expression of keratin and vimentin using immunofluorescence techniques as described previously (22). These studies verified that HMC reacted with antibodies for both keratins (AE1, AE3 and 24A3) and vimentin. HAL, obtained from N.I.A. Aging Cell Culture repository Institute for Medical Research (Camden NJ) were maintained in Minimal Essential Medium (MEM, GIBCO) containing $50 \mathrm{U} / \mathrm{ml}$ penicillin, $50 \mu \mathrm{g} / \mathrm{ml}$ streptomycin, and $10 \%$ fetal bovine serum as described elsewhere (23). Both cell types were grown to confluence in 100 mm dishes (Coming Glass Works, Coming,NY) and exposed to test agents in complete medium. Asbestos and other particulates were suspended in Hanks Balanced Salt Solution (HBSS, GIBCO) and added to cells directly (21). Xanthine $(50 \mu \mathrm{M})$ was dissolved in medium in absence and presence of $\mathrm{XO}$ at various concentrations $(0-0.4 \mathrm{U} / \mathrm{ml})$.

Cytotoxicity assays: To determine concentrations of asbestos and $\mathrm{X} / \mathrm{XO}$ that were nontoxic to HMC and HAL cells, cells were grown to confluence in multi-well dishes and exposed to test agents. Cytotoxicity at 24 hrs. after addition of agents, was assessed by quantitation of cell-associated protein ( $N=4 / g r o u p / c o n c e n t r a t i o n)$ according to the Bradford technique (24). Assays were performed in duplicate.

Northern blot analyses: Total RNA was extracted from cells according to the procedure of Chomczynski and Sacchi (25). Purity and concentration were determined by measuring UV absorbance at 260 and $280 \mathrm{~nm}$. Fifteen $\mu \mathrm{g}$ of total RNA was electrophoresed, transferred onto nitrocellulose filters and hybridized with $\left[{ }^{32} \mathrm{P}\right]$-labeled cDNA probes (26). Rat MnSOD cDNA was obtained from Y.-S. Ho, Wayne State University, Detroit MI (27), and a human HO cDNA probe was generously provided by R. Tyrrell, Swiss Institute for Experimental Cancer Research, Epalinges, Switzerland (18). Radioactivity on blots was quantitated directly using a Betascope blot analyzer (Betagen Corp., Waltham, MA). In addition, hybridization signals on blots were visualized by exposure to Kodak $\mathrm{X}$-Omat AR film (Rochester NY) at $-80^{\circ} \mathrm{C}$ with intensifying screens. To ascertain that increased mRNA levels were not due to differences between RNA contents of blots, representative blots were stripped and reprobed with a 
glyceraldehyde-3- phosphate dehydrogenase (GAPDH) cDNA probe, obtained from Dr. Jeanteur, Laboratoire de Biochimie, Centre Paul Lamarque, France.

Western blot analyses: Cells were washed twice with cold CMFPBS, scraped with a rubber policeman, and spun for 4 minutes at $1500 \mathrm{rpm}$ in a clinical centrifuge. The supernatant was decanted, and cell pellets were resuspended in $0.025 \mathrm{M}$ potassium phasphate buffer, ( $\mathrm{pH} 7.8$ ) containing $50 \mu \mathrm{M}$ ethylenediaminetetraacetic acid, $3 \mathrm{mM}$ phenylmethyl-sulfonylfluoride, $3 \mathrm{mM}$ benzamidine and $1.27 \mathrm{mM} \mathrm{N}_{\alpha}$-p-tosyl-L-arginine methylester. Cells were sonicated on ice 6 times for 10 seconds at 100 watts with intervals of 10 seconds, and lysates were spun for 5 minutes, $14,000 \mathrm{rpm}$ at $4^{\circ} \mathrm{C}$ in a microcentrifuge. Supernatants were stored at $-80^{\circ} \mathrm{C}$ for analysis of protein content and western blotting. Protein concentrations were determined by the Bradford technique (24). Prior to electrophoresis, samples were lyophilized and reconstituted in sample buffer and electrophoresed in $15 \%$ sodium dodecyl sulfate-polyacrylamide gels (28). Blots were stored at $4^{\circ} \mathrm{C}$ in PBS until analysis. Nonspecific binding was blocked by incubation with PBS-Tween $(0.05 \%)$ for 30 minutes. Subsequently, blots were incubated with a primary anti-human kidney MnSOD antibody (L.W. Oberley, University of Iowa, Iowa City IA, 19) for 1 hour. Blots were washed with PBS-Tween, and incubated with peroxidase-conjugated anti-rabbit IgG (Vector laboratories, Burlingame, CA). Protein bands were visualized with the ECL Westem blotting Detection system (Amersham, Arlington Heights, IL).

\section{Results}

Cytotoxicity: as shown in Table 1, HMC and HAL cells showed no alterations in amounts of protein after exposure to crocidolite asbestos or X/XO at concentrations less than $25 \mu \mathrm{g} / \mathrm{cm}^{2}$ and $0.2 \mathrm{U} / \mathrm{ml}$, respectively. In subsequent studies, agents were used at lower concentrations exhibiting no obvious cytotoxicity after an exposure period of 24 hours.

Gene expression of MnSOD and $\mathrm{HO}$ in HMC following exposure to crocidolite asbestos or X/XO: one objective of work here was to determine if sensitivity of HMC to asbestos correlated with alterations in gene expression of the antioxidant enzymes, MnSOD and HO. Figure 1 shows a time course of MnSOD gene expression at 2,8 and 24 hours after exposure to $2.5 \mu \mathrm{g} / \mathrm{cm}^{2} / \mathrm{dish}$ crocidolite asbestos, or $0.1 \mathrm{U} / \mathrm{ml} \mathrm{X/XO}$. The 1 and $4 \mathrm{~kb}$ bands reflecting the major mRNA species for MnSOD are indicated, and quantitated in all experiments using a Betascope blot analyzer. Crocidolite asbestos caused slight increases in MnSOD mRNA levels after 8 and 24 hours of exposure. However, more dramatic increases (2-3 fold) in MnSOD mRNA levels were observed following exposure of cells to $\mathrm{X} / \mathrm{XO}$ at these time periods. More striking 
TABLE 1 Cytotoxicity of crocidolite asbestos and xanthine/xanthine oxidase (X/XO) afier addition to human mesothelial cells (HMC) or human adult lung fibroblasts (HAL) for 24 hours.

\begin{tabular}{llll}
\hline & & \multicolumn{2}{l}{ Protein content of dish" } \\
\cline { 3 - 4 } & & HMC & HAL \\
\hline Control & & $25.0(1.3)$ & $22.5(1.1)$ \\
& & & \\
Asbestos & $2.5^{\dagger}$ & $29.7(2.2)$ & $22.8(2.1)$ \\
& 10.0 & $30.2(2.3)$ & $21.3(1.6)$ \\
& 25.0 & $28.7(2.5)$ & $22.6(1.5)$ \\
X/XO & $0^{\ddagger}$ & $26.1(1.2)$ & $22.6(1.2)$ \\
& 0.025 & $22.7(1.4)$ & $18.0(1.1)$ \\
& 0.05 & $22.0(1.3)$ & $19.5(1.1)$ \\
& 0.1 & $21.7(1.2)$ & $19.7(1.0)$ \\
& 0.2 & $22.7(0.7)$ & $19.2(0.8)$ \\
\hline
\end{tabular}

"Mean and S.E.M. (in parentheses) of $N=4 /$ group as determined by the Bradford technique. No significant differences from controls or trends with dose were observed using analysis of variance; ${ }^{\dagger} \mu \mathrm{g} / \mathrm{cm}^{2}$ area of dish; ${ }^{\dagger} 50 \mu \mathrm{M}$ xanthine plus xanthine oxidase (U/ml medium).

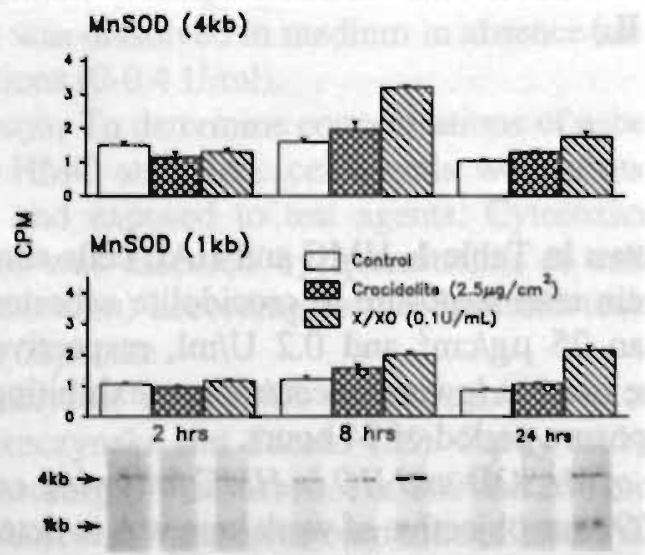

Figure 1. Time course of MnSOD mRNA expression in HMC after exposure to crocidolite asbestos and XIXO. HMC 9017 cells were grown to confluence, and fed with complete medium at the time of addition of test agents. Crocidolite was suspended in HBSS and added at a concentration of $2.5 \mu \mathrm{g} / \mathrm{cm}^{2}$ area of dish. Cells treated with $X / X O$ were fed with fresh medium containing $50 \mu M$ xanthine $(X)$ and $X O$ was added at a final concentration of 0.1 U/ml. After 2,8, and 24 hours of exposure RNA was extracted and Northern blot analyses performed. Blots were hybridized with a $\left.{ }^{32} P\right]$-labeled rat cDNA encoding MnSOD, washed and $1 \mathrm{~kb}$ and $4 \mathrm{~kb}$ bands quantitated using a Betascope blot analyzer. Results are expressed as counts per minute. 
elevations in gene expression of $\mathrm{HO}$ were seen following exposure of $\mathrm{HMC}$ to crocidolite or $\mathrm{X} / \mathrm{XO}$ (Figure 2), but mRNA levels of GAPDH were unchanged (Figure 2). Accordingly, normalization of MnSOD or $\mathrm{HO}$ hybridization signals to GAPDH mRNA did not alter the magnitude of changes observed in all experiments (data not shown).

The dose responsive nature of increases in gene expression of MnSOD and $\mathrm{HO}$ following exposure of $\mathrm{HMC}$ to graded concentrations of crocidolite or $X / X O$ is demonstrated in Figures 3 and 4. As shown in Figure 3, increases in both 1 and $4 \mathrm{~kb}$ MnSOD mRNA species are observed in a dose response fashion after 24 hours of exposure to asbestos. In addition, exposure of these cells to increased amounts of $\mathrm{X} / \mathrm{XO}$ resulted in more pronounced increases in MnSOD mRNA levels. However, addition of riebeckite, a non-fibrous particle chemically identical to crocidolite asbestos, failed to alter MnSOD mRNA levels. Figure 4 shows HO mRNA levels in HMC line 9017 after 24 hours of exposure to crocidolite or X/XO. Similarly, both crocidolite and X/XO caused dose dependent increases in $\mathrm{HO}$ mRNA levels whereas addition of riebeckite failed to alter HO mRNA levels. In order to determine whether HMC from different patients showed similar patterns in gene expression of MnSOD and HO, we compared 2 different HMC lines after exposure to asbestos. Figures 5 and 6 show that both HMC 9015 and 9017 respond to crocidolite asbestos by increasing MnSOD and HO mRNA levels.

Protein levels of MnSOD in HMC after exposure to asbestos or X/XO: To determine whether increases in gene expression of MnSOD in HMC after exposure to asbestos or $\mathrm{X} / \mathrm{XO}$ were accompanied by increased immunoreactive protein levels of MnSOD, we performed Western blot analyses at various time points after exposure. Figure 7 shows that modest increases in MnSOD immunoreactive protein occur at 48 hours after exposure to crocidolite or X/XO.

Gene expression of MnSOD and HO in HAL following exposure to crocidolite asbestos or X/XO:In addition to HMC, we also examined HAL to determine whether similar alterations in gene expression of MnSOD and HO occurred following exposure to crocidolite or X/XO. Figures 8 and 9 show the time course of gene expression of MnSOD and HO in HAL after addition of crocidolite or $\mathrm{X} / \mathrm{XO}$. Crocidolite asbestos did not alter MnSOD or HO mRNA levels. However, addition of X/XO caused increases in MnSOD mRNA levels at all time points. Transient, but more striking increases in $\mathrm{HO}$ mRNA levels were observed at 2 and 4 hours following administration of X/XO and decreased towards control levels at 24 hours. These patterns of expression may be related to the self-limiting oxidant production in the $\mathrm{X} / \mathrm{XO}$ generating system. Figures 10 and 11 show results of a dose response study using crocidolite asbestos. No alterations in MnSOD mRNA levels and only moderate changes in HO mRNA levels at the highest concentrations of asbestos were observed. Riebeckite failed 


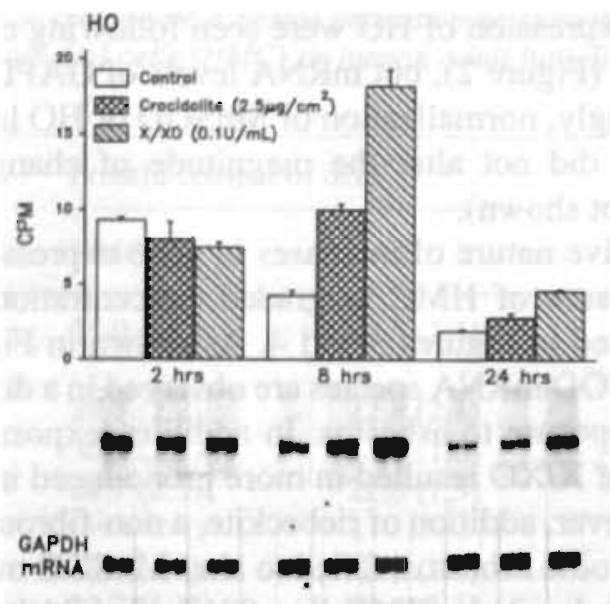

Figure 2. Time course of HO mRNA expression in HMC 9017 cells after exposure to crocidolite asbestos and $\mathrm{X} / \mathrm{XO}$. Cells were exposed to test agents as described in figure 1. Blots were hybridized with [ ${ }^{32} P$ ]-labeled $c D N A$ encoding HO. Hybridization signals were quantitated using a Betascope apparatus. Subsequently, the blot was stripped and reprobed with a cDNA encoding GAPDH, as a housekeeping probe, shown in the bottom panel. Different hybridization blots and conditions for samples at 2 hours vs. those at 8 and 24 hours account for higher cpm in control samples at 2 hours.

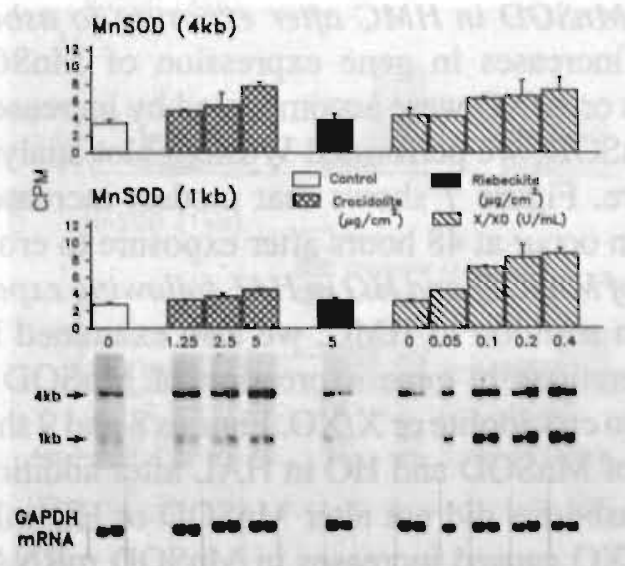

Figure 3. Dose response study of MnSOD mRNA expression in HMC afier 24 hours of exposure to crocidolite asbestos or X/XO. HMC 9017 cells were cultured as described above and exposed to increasing amounts of crocidolite asbestos, $1.25,2.5$ or $5 \mu \mathrm{g} / \mathrm{cm}^{2}$ dish. Cells exposed to X/XO were fed with fresh medium containing $50 \mu \mathrm{MX}$ along with increasing amounts of XO $0.05,0.1,0.2 \mathrm{or} 0.4 \mathrm{U} / \mathrm{ml}$. Riebeckite, the non-fibrous crocidolite analog was added at $5 \mu \mathrm{g} / \mathrm{cm}^{2}$ dish. After 24 hours of exposure RNA was extracted and Northern blot analyses performed. Blots were probed with MnSOD and quantitated as described above. Subsequent hybridization with GAPDH cDNA revealed no differences in RNA contents between lanes (bottom panel). 


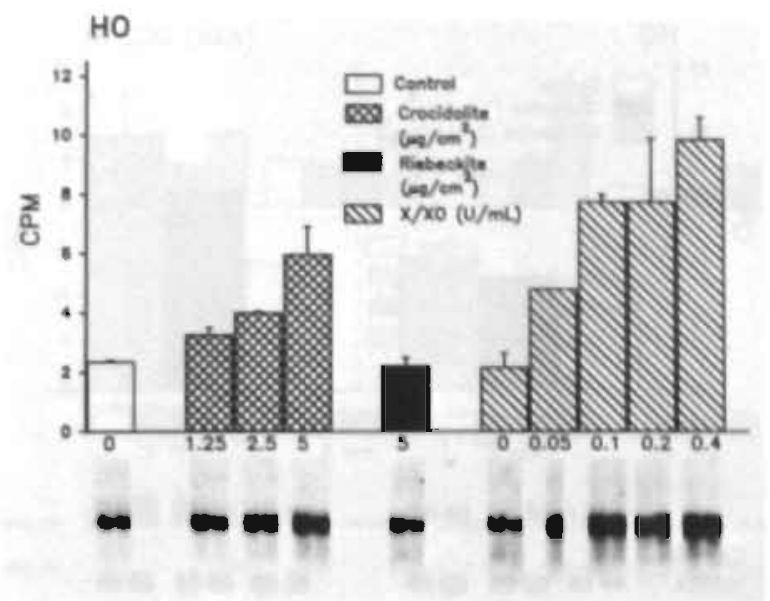

Figure 4. Dose response study of HO mKNA expression in HMC after 24 hours of exposure to crocidolite asbestos or $\mathrm{X} / \mathrm{XO}$. HMC 9017 cells were exposed to crocidolite asbestos at $1.25,2.5$, or $5 \mu \mathrm{g} / \mathrm{cm}^{2}$ dish, or $50 \mu \mathrm{MX}$ along with increasing amounts of $X O 10.05,0.1,0.2$ or $0.4 U \mathrm{XO} / \mathrm{ml}$ ), or riebeckite at $5 \mu \mathrm{g} / \mathrm{cm}^{2}$ area dish. Northern blots were hybridized with a $I^{32} P J$-labeled cDNA encoding HO and quantitated on a Betascope blot apparatus.

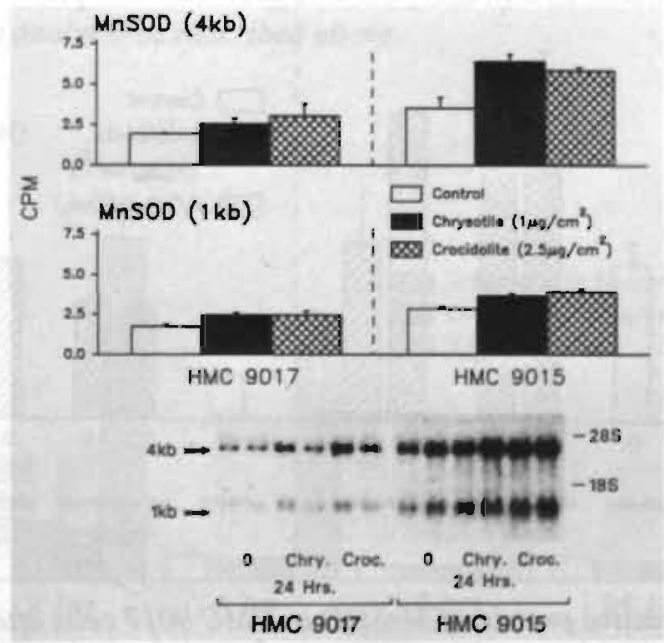

Figure 5. Steady-state mRNA levels of MnSOD in HMC 9015 and 9017 afier 24 hours of exposure to asbestos. HMC 9015 and 9017 cells were grown to confluence, fed with fresh culture medium and exposed to $2.5 \mu \mathrm{g} / \mathrm{cm}^{2}$ crocidolite asbestos or $1 \mu \mathrm{g} / \mathrm{cm}^{2}$ chrysotile asbestos for 24 hours. $15 \mu \mathrm{g}$ of RNA per lane was electrophoresed and Northern blot analyses performed. Blots were hybridized with [ ${ }^{32} P$ ]-labeled MnSOD CDNA, and quantitated as described above. 


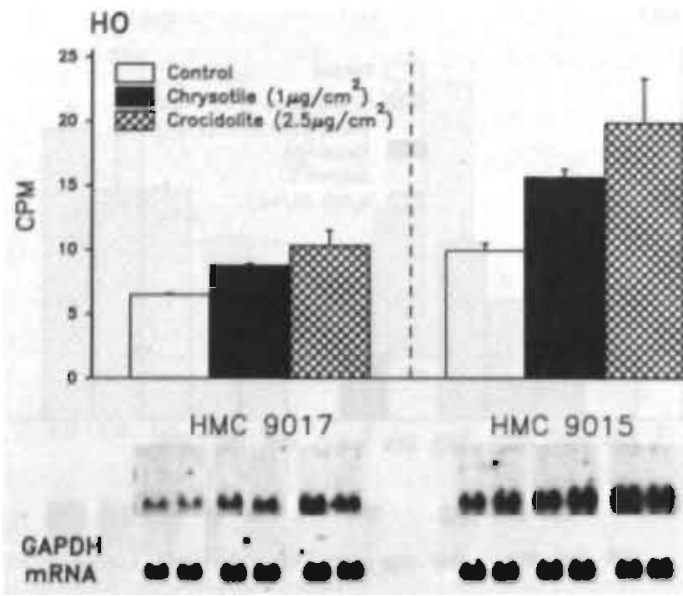

Figure 6. Steady-state mRNA levels of HO in HMC 9015 and 9017 celils afier 24 hours of exposure $102.5 \mu \mathrm{g} / \mathrm{cm}^{2}$ crocidolite asbestos or $1 \mu \mathrm{g} / \mathrm{cm}^{2}$ chrysotile asbestos. Northern blots containing $15 \mu g$ RNAllane were probed with a $]^{32} 2$ J-labeled HO cDNA. Blots were quantitated on a Betascope apparatus, stripped and reprobed with a cDNA encoding GAPDH to ascertain equal amounts of RNA. GAPDH mRNA levels, shown in bottom panels revealed no differences between lanes.

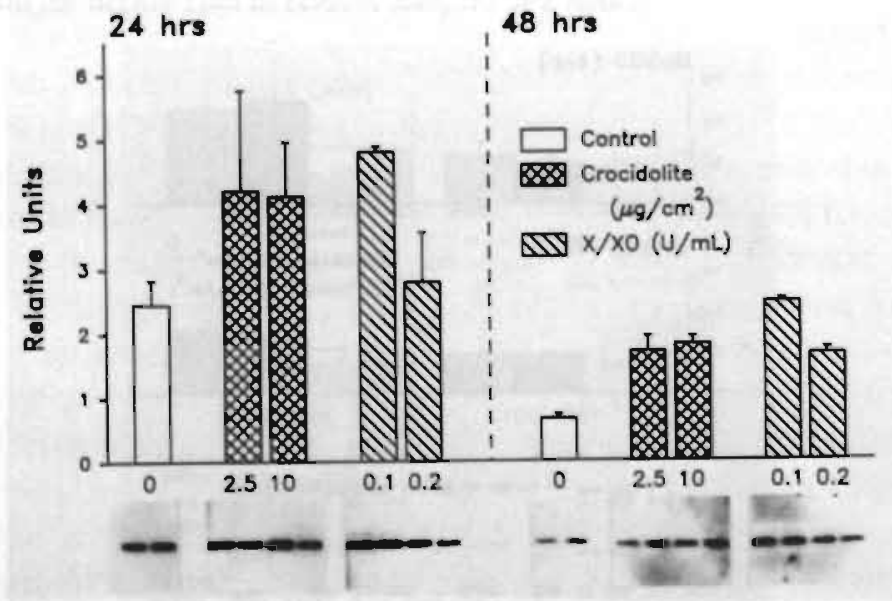

Figure 7. Immunoreactive protein of MnSOD in HMC 9017 cells after 24 and 48 hours of exposure to crocidolite asbestos $\left(2.5\right.$ or $\left.10 \mu \mathrm{g} / \mathrm{cm}^{2}\right)$ or $X / X O(0.1$ or $0.2 \mathrm{U} / \mathrm{ml}) .100$ or 200 ng quantities of protein obtained from HMC lysates were electrophoresed in $15 \%$ acrylamide gels, transferred onto nitrocellulose and incubated with a human MnSOD polyclonal antibody. After incubation with a peroxidase labeled secondary antibody, blots were washed and reacted with the ECL chemiluminescent reagent (Amersham), and exposed to Kodak X Omat film for $1-5$ seconds. The blots from the 24 and 48 hour exposure period contain 200 and $100 \mathrm{ng}$ proteinllane, respectively. Only one band of $23 \mathrm{kD}$ is detectable, as described previously (26) 


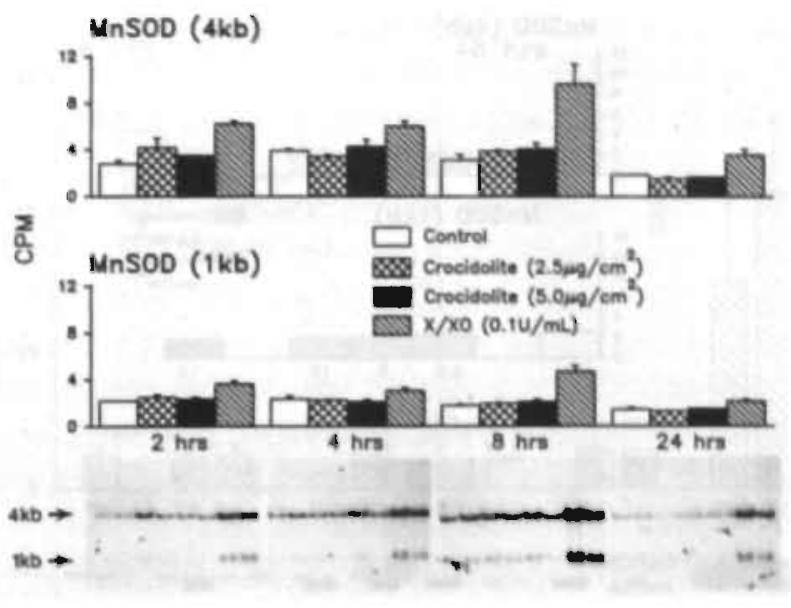

Figure 8. Time course of mRNA levels of MnSOD in HAL cells after exposure to crocidolite asbestos or X/XO. HAL cells were grown to confluence, fed with fresh medium at the time of addition of test agents. Crocidolite asbestos was suspended in HBSS and added to cells in a final concentration of 2.5 or $5 \mu \mathrm{g} / \mathrm{cm}^{2}$ area of dish. Cells treated with $X / X O$ were fed with fresh culture medium containing $50 \mu \mathrm{MX}$ along with $0.1 \mathrm{U} / \mathrm{ml} \mathrm{XO}$. After $2,4,8$, and 24 hours of exposure RNA was extracted and Northern blot analysis performed. Blots were hybridized with a $\left.{ }^{32} P\right]$-labeled $C D N A$ probe encoding $M n S O D$, and hybridization signals quantitated using a Betascope blot analyzer as described above.

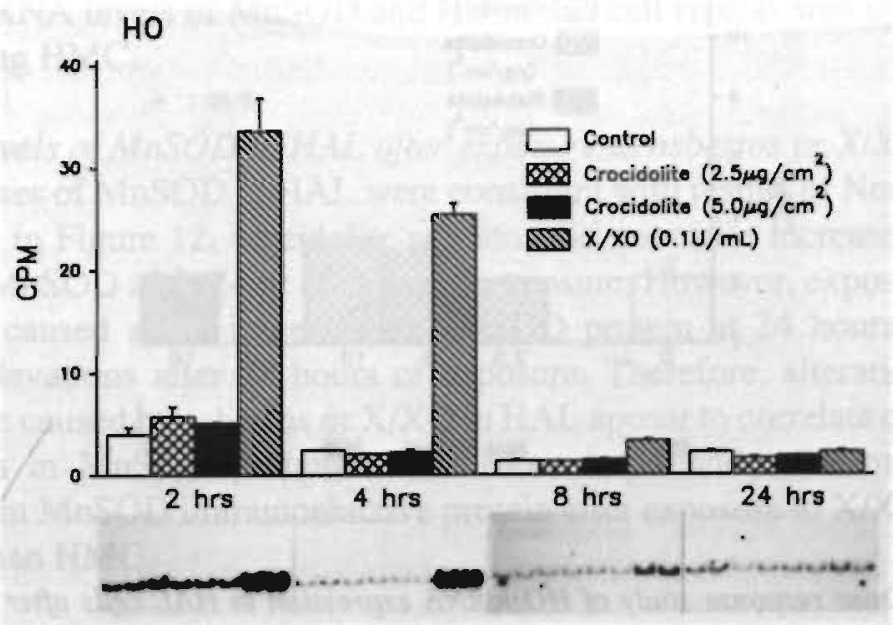

Figure 9. Time course of mRNA levels of HO in HAL cells afier exposure to crocidolite asbestos or X/XO. HAL cells were cultured and treated as described in Figure 8. Northern blots were probed with a [ $\left.{ }^{32} \mathrm{P}\right]$-labeled $H O \mathrm{cDNA}$, and quantitated on a Betascope analyzer. 


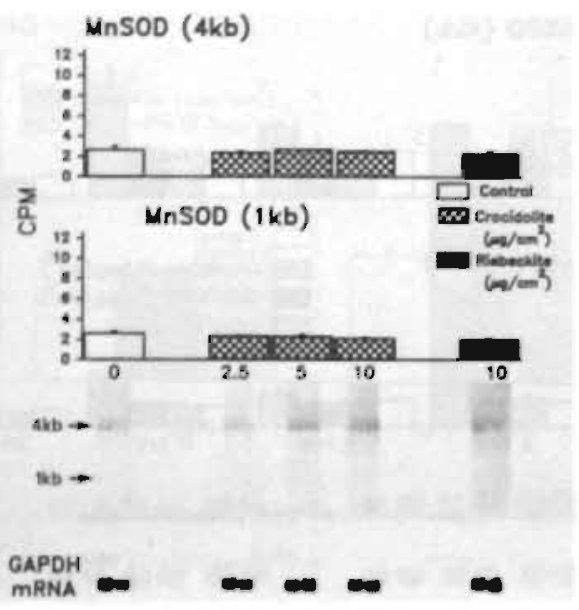

Figure 10. Dose response study of MnSOD mRNA expression in HAL cells after 24 hours of exposure to increasing concentrations of crocidolite asbestos, $2.5,5$, and $10 \mu \mathrm{g} / \mathrm{cm}^{2}$ or 10 $\mu \mathrm{g} / \mathrm{cm}^{2}$ riebeckite. Northern blots were probed with I $^{32}$ PJ-labeled $c D N A$ encoding MnSOD mRNA, and quantitated on a Betascope apparatus. Subsequently blots were stripped and reprobed with GAPDH cDNA to confirm homogeneity in RNA contents between lanes (bottom panel).

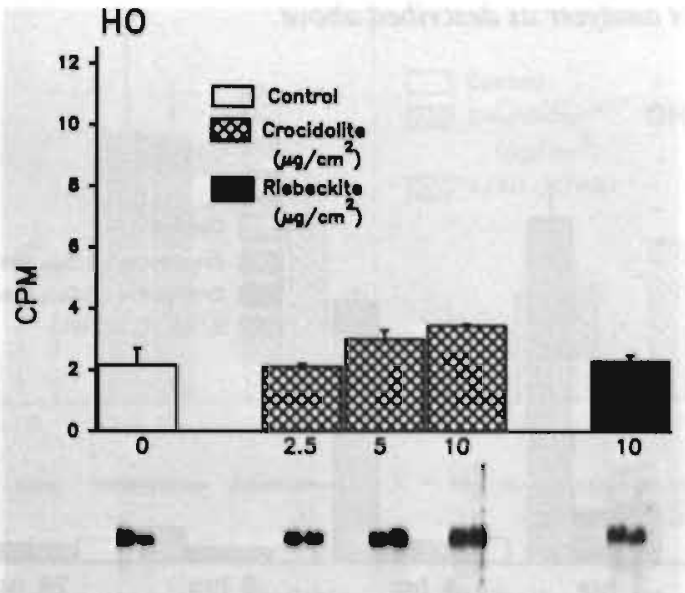

Figure 11. Dose response study of HO mRNA expression in HAL cells after 24 hours of exposure to increasing concentrations of crocidolite asbestos, $2.5,5$, and $10 \mu \mathrm{g} / \mathrm{cm}^{2}$ or 10

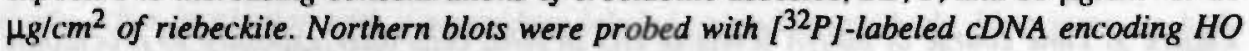
and quantitated on a Betascope apparatus. 


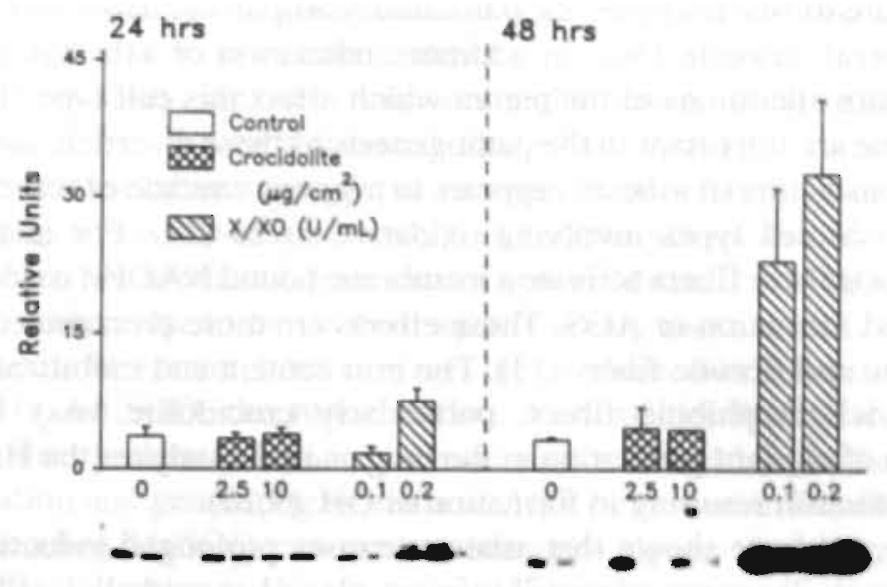

Figure 12. Immunoreactive protein of MnSOD in HAL cells after 24 and 48 hours of exposure to crocidolite asbestos $\left(2.5\right.$ or $\left.10 \mu \mathrm{g} / \mathrm{cm}^{2}\right)$ or $X / X O(0.1$ or $0.2 \mathrm{U} / \mathrm{ml})$. 1 or $2 \mu \mathrm{g}$ protein from HAL cell lysates were electrophoresed in $15 \%$ acrylamide gels, transferred onto nitrocellulose and incubated with MnSOD antibody. Protein bands were visualized as described in figure 7 . The blot from the 24 hour time point contains $2 \mu \mathrm{g}$ of protein per lane, whereas the blot prepared from cell extracts after 48 hours of exposure to test agents contains $I \mu \mathrm{g}$ of protein/lane.

to alter mRNA levels of MnSOD and HO in this cell type as was demonstrated above using HMC.

Protein levels of MnSOD in HAL after exposure to asbestos or X/XO. Western blot analyses of MnSOD in HAL were consistent with results of Northem blots. As shown in Figure 12, crocidolite asbestos did not cause increases in protein levels of MnSOD after 24 or 48 hours of exposure. However, exposure of HAL to $\mathrm{X} / \mathrm{XO}$ caused small increases in MnSOD protein at 24 hours, and more striking elevations after 48 hours of exposure. Therefore, alterations in gene expression caused by asbestos or X/XO in HAL appear to correlate directly with alterations in MnSOD protein levels. More importantly, the magnitude of increases in MnSOD immunoreactive protein after exposure to X/XO is greater in HAL than HMC.

\section{Discussion}

Little is known about the cell biology of mesothelial cells, the progenitor cells of malignant mesothelioma. This highly invasive tumor is associated in humans 
with exposure to fibrous minerals, particularly amphibole asbestos (29) and the zeolite mineral, erionite (30). In addition, inhalation of asbestos also causes non-malignant alterations of the pleura which affect this cell type. The cellular reactions that are important in the pathogenesis of these disorders are unknown.

The fibrous nature of asbestos appears to trigger a cascade of reactions within a multitude of cell types involving oxidative stress (31). For instance, cells phagocytosing these fibers activate a membrane bound NADPH oxidase leading to prolonged formation of AOS. These effects are more pronounced with long carcinogenic and fibrotic fibers (13). The iron content and mobilization of iron from iron-rich amphibole fibers, particularly crocidolite, may be another mechanism of oxidant generation in the lung as iron catalyzes the Haber-Weiss or Fenton reaction resulting in formation of $\mathrm{OH}^{\cdot}(9,10)$.

Recently, we have shown that asbestos causes prolonged induction of c-fos and c-jun protooncogene expression in rat pleural mesothelial cells, whereas riebeckite, or other mineral fibers not giving rise to pulmonary disease failed to induce these genes at the concentrations that were tested (32). Persistent induction of the early response gene pathway may lead to chronic cell proliferation and asbestos-induced pleural disease. In addition, steady-state mRNA levels and activity of ornithine decarboxylase (ODC), an enzyme intrinsic to cell proliferation, are induced by asbestos fibers but not by non-fibrous particulates (21). Since induction of ODC by asbestos is abolished by concomitant exposure to antioxidants, AOS might be important mediators of cell proliferation caused by asbestos (5). Alternatively, AOS released by inflammatory cells or generated intrinsically by asbestos fibers could trigger some of the molecular events described above. Since AOS are important mediators of asbestos-induced cell proliferation, inflammation and fibrosis (8), antioxidant defenses of cells and tissues could be critical to prevention of asbestos-induced disease.

Previously, we have shown that inhalation of asbestos leads to increased mRNA levels of antioxidant enzymes (MnSOD, catalase, glutathione peroxidase) in rat lungs at selected time points during or after exposure. The magnitude of increases in gene expression of MnSOD in these studies was greater than elevations in mRNAs of other antioxidant enzymes including catalase and glutathione peroxidase (26). Immunocytochemistry also revealed strikingly increased protein levels of MnSOD in type II pneumocytes in rat lung after inhalation of asbestos or silica (33).

Endogenous levels of antioxidant enzymes and antioxidant defense mechanisms have not been studied in HMC. Kinnula and coworkers recently investigated different antioxidant pathways after addition of hydrogen peroxide to rat pleural mesothelial cells using biochemical techniques involving modulators of activities of endogenous antioxidant enzymes (34). These studies showed that the glutathione redox cycle is important in protection against low 
levels of oxidative stress, whereas catalase becomes more significant in protection of cells against severe oxidative stress.

In the present study, we used molecular techniques to study oxidative stress responses in HMC. We hypothesized that HMC might be compromised in antioxidant defense after exposure to asbestos or generating systems of AOS thus reflecting an increased sensitivity to oxidative stress. In order to address this hypothesis, we measured gene expression of MnSOD and $\mathrm{HO}$, since both genes are readily induced by AOS or agents giving rise to AOS formation in other cell types. Moreover, both enzymes are implicated in cell defense against oxidants (31). MnSOD, the mitochondrial form of the SODs, is selectively induced by the cytokines, Tumor Necrosis, Factor- $\alpha$ and Interleukin 1, hyperoxia, irradiation and generating systems of AOS (reviewed in 31). Transfection of genes encoding MnSOD into mammalian cells also confers increased resistance to oxidant stresses such as paraquat (35) and asbestos (Surinrut et al., in preparation). Moreover, pretreatment of cells with agents that induce MnSOD leads to adaptation to subsequent oxidant injury $(31,36)$. These studies all suggest a protective role of MnSOD against oxidative damage.

In this study, we also investigated mRNA levels of $\mathrm{HO}$, an enzyme traditionally not examined as an antioxidant. However, $\mathrm{HO}$, by converting heme to biliverdin, reduces available heme pools which can be prooxidants (16). Moreover bilirubin, generated by biliverdin reductase, a subsequent enzyme in the heme catabolizing pathway has antioxidant properties. HO mRNA is induced by many oxidant stresses, especially agents that deplete glutathione (37). Therefore, examination of both MnSOD and $\mathrm{HO}$ gene expression in $\mathrm{HMC}$ after exposure to asbestos or AOS is a sensitive tool to investigate whether mesothelial cells are able to respond to oxidative stress. Results here also provide indirect evidence supporting the hypothesis that asbestos-mediated biological effects are mediated by AOS (13).

Our results show that HMC are not compromised in their ability to induce gene expression of MnSOD or HO after exposure to oxidative stress. In HAL cells, asbestos did not cause elevations in mRNA or protein levels of MnSOD, and increased HO mRNA was observed only at highest concentrations of fibers tested. However, X/XO induced gene expression of MnSOD and HO efficiently in this cell type. These results suggest that distinct cell types may respond differentially to certain oxidative stresses including asbestos.

A different temporal pattern of expression of $\mathrm{HO}$ also occurred in $\mathrm{HMC}$ and HAL cells in response to $\mathrm{X} / \mathrm{XO}$. For example, in HAL cells, the response peaked at 2 hours and was diminished at 8 hours, the time of maximal induction of $\mathrm{HO}$ in HMC cells. The early peak in message levels of $\mathrm{HO}$ may reflect the fact that continuous oxidant generation in this chemical generating system may be self-limiting and attenuated with time. Alternatively, cells after initial induction of $\mathrm{HO}$ may adapt to this oxidative stress with time in culture. Another interesting 
finding was the magnitude of increase in MnSOD immunoreactive protein in HAL cells when compared to the minor increases observed in HMC in response to $\mathrm{X} / \mathrm{XO}$, especially at 48 hours post exposure (Figures 7 and 12). Although strict comparisons between cell types demand further study, the striking increases in HAL cells in comparison to HMC suggest that differences might exist in post-transcriptional regulation of antioxidant enzymes between various cell types.

\section{Acknowledgements}

The authors thank Dr. Janet Mitchell, Department of Physiology and Biophysics, University of Vermont for immunocytochemistry of vimentin and keratins in HMC, Judith Kessler for illustrations, Pamela Vacek, Department of Biometry, University of Vermont for statistical analyses, and Linda Allen and Betty Nienstedt for technical assistance.

This work was funded by a grant (R01HL39469) from the National Institutes of Health and a grant from the Environmental Protection Agency. 


\section{REFERENCES}

1 Mossman BT, Gee JBL. Medical progress. Asbestos-related diseases. N Engl J Med 1989; 320:1721-30.

2 Mossman BT, Marsh JP, Shatos MA. Alteration of superoxide dismutase (SOD) in tracheal epithelial cells by asbestos and inhibition of cytotoxicity by antioxidants. Lab Invest 1986; 54: 204-212.

3 Shatos MA, Doherty MA, Marsh JP, Mossman BT. Prevention of asbestos-induced cell death in rat lung fibroblasts and alveolar macrophages by scavengers of active oxygen species. Environ Res 1987; 44:103-116.

4 Goodlick LA, Kane AB. Role of reactive oxygen metabolites in crocidolite asbestos toxicity to mouse macrophages. Cancer Res 1986; 46:5558-66.

5 Marsh JP, Mossman BT. Role of asbestos and active oxygen species in activation and expression of ornithine decarboxylase in hamster tracheal epithelial cells. Cancer Res 1991; 51:167-73. 6Petruska JM, Marsh J, Bergeron M, Mossman BT. Brief inhalation of asbestos compromises superoxide production in cells from bronchoalveolar lavage. Am J Respir Cell Mol Biol 1990; 2:129-36.

7 Cantin A, Dubois F, Begin R. Lung exposure to mineral dusts enhances the capacity of lung inflammatory cells to release superoxide. J Leukocyte Biol $1988 ; 43: 299-303$.

8 Mossman B'T, Marsh JP, Sesko A, Hill S, Shatos MA, Doherty J, Petruska J, Adler KB, Hemenway D, Mickey R, Vacek P, Kagan E. Inhibition of lung injury, inflammation, and interstitial pulmonary fibrosis by polyehylene glycol-conjugated catalase in a rapid inhalation model of asbestosis Am Rev Respir Dis 1990; 141:1266-71.

9 Weitzman SA, Graceffa P. Asbestos catalyzes hydroxyl ans superoxide radical generation from hydrogen peroxide. Arch Biochem Biophys 1984; 228: 373-6.

10 Zalma R, Bonneau L, Jaurand MC, Guignard J, Pezerat H. Formation of oxy-radicals by oxygen reduction arising from the surface activity of asbestos. Can J Chem 1988; 65:2338-41.

11 Hansen, K.; Mossman, B.T. Generation of superoxide $\left(\mathrm{O}_{\overline{2}}\right)$ from alveolar macrophages exposed to asbestiform and nonfibrous particles. Cancer Res. 47:1681-1686;1987.

12 Hedenborg M, Klockars M. Production of reactive oxygen metabolites induced by asbestos fibres in human polymorphonuclear leucocytes. J Clin Pathol 1987; 40:1189-93.

13 Mossman BT, Marsh JP. Role of active oxygen species in asbestos-induced cytotoxicity, cell proliferation, and carcinogenesis. In: Harris CC, Lechner JF, Brinkley BR (Eds.) Cellular and Molecular Aspects of Fiber Carcinogenesis. Cold Spring Harbor, 1991, pp 159-168.

14 Lechner JF, Tokiwa T, LaVeck M, Benedict WF, Banks-Schlegel S, Yeager Jr H, Banerjee A, Harris CC. Asbestos-associated chromosomal changes in human mesothelial cells. Proc Natl Acad Sci U.S.A. 1985; 82:3884-8.

15 Anthony VB, Sahn SA, Mossman BT, Berlin Gail D, Kalica A. Pleural cell biology in health and disease. Am Rev Respir Dis 1992; 145:1236-9.

16 Keyse SM, Applegate LA, Tromvoukis Y, Tyrrell RM. Oxidant stress leads to transcriptional activation of the human heme oxygenase gene in cultured skin fibroblasts. Mol Cell Biol 1990; 10:4967-9.

17 Keyse SM, Tyrrell RM. Induction of the heme oxygenase gene in human skin fibroblasts by hydrogen peroxide and UVA $(365 \mathrm{mn})$ radiation: evidence for the involvement of the hydroxyl radical. Carcinogenesis 1989; 11:787-91. 
18 Keyse SM, Tyrrell RM. Heme oxygenase is the majoi 32-kDa stress protein induced in human skin fibroblasts by UVA radiation, hydrogen peroxide, and sodium arsenite. Proc Natl Acad Sci USA 1989; 86:99-103.

19 Oberley TD, Oberley LW, Slattery AF, Lauchner LJ, Elwell JH. Immunohistochemical localization of antioxidant enzymes in adult syrian hamster tissues and during kidney development. Am J Pathol 1990; 137:199-214.

20 Kuppusamy $\mathrm{P}, \mathrm{Z}$ weier IL. Characterization of free radical generation by $x$ anthine oxidase. Evidence for hydroxyl radical generation. J Biol Chem 1989; 264:9880-4.

21 Marsh IP, Mossman BT. Mechanisms of induction of omithine decarboxylase activity in tracheal epithelial cells by asbestiform minerals. Cancer Res 1988:48:709-14.

22 Mitchell JJ, Low RB, Woodcock-Mitchell J. Cytomatrix synthesis in MDCK epithelial cells. J Cell Physiol 1990; 143:501-11.

23 Kelley J, Fabisiak JP, Hawes K, Absher M. Cytokine signalling in the lung: TGF- $\beta$ secretion by lung fibroblasts. Am J Physiol (Lung) 1991; 260:123-8.

24 Bradford MN. A rapid sensitive method for the quantitation of microgram quantities of protein utilizing the principal of protein-dye binding. Anal Biochem 1976; 72:248-54.

25 Chomczynski P, Sacchi N. Signle step method of RNA isolation by acid guanidinium thiocyanate-phenol-chloroform extraction. Anal Biochem 1987; 162:156-9.

26 Janssen YMW, Marsh JP, Absher MP, Hemenway D, Vacek PM, Leslie KO, Borm PJA, Mossman BT. Expression of antioxidant enzymes in rat lung after inhalation of asbestos or silica. J Biol Chem 1992; 267: 10625-30.

27 Ho YS, Howard AJ, Crapo JD. Molecular structure of a functional rat gene for manganese-containing superoxide dismutase. Am J Respir Cell Mol Biol 1991; 4:278-86.

28 Edmondson SW, Wu R, Mossman BT. Regulation of differentiation and keratin protein expression by vitamin A in primary cultures of hamster tracheal epithelial cells. J Cell Physiol 1990; 142:21-30.

29 Mossman BT, Bignon J, Com M, Seaton A, Gee JBL. Asbestos: Scientific developments and implications for public policy. Science 1990; 247:294-301.

30 Artvinli M, Baris YI. Malignant mesothelioma in a small village in the Anatolian region in Turkey: an epidemiological study. J Natl Cancer Inst 1979; 63:17-22.

31 Janssen YMW, van Houten B, Borm PJA, Mossman BT. Cell and tissue responses to oxidative damage. Lab Invest (in press).

32 Heintz NH, Janssen YMW, Mossman BT. Persistent induction of c-fos and c-jun expression by asbestos. Proc Natl Acad Sci USA 1993; 90:3299-3303.

33 Holley JA, Janssen YMW, Mossman BT, Taatjes D. Increased manganese superoxide dismutase protein in type II epithelial cells of rat lungs after inhalation of crocidolite asbestos or cristobalite silica. Am J Pathol 1992; 141:475-85.

34 Kinnula VL, Everitt JI, Mangum JB, Chang L-Y, Crapo JD. Antioxidant defense mechanisms in cultured pleural mesothelial cells. Am J Respir Cell Mol Biol 1992; 7:95-103.

35 St.Clair D, Oderley TD, Ho YS. Overproduction of human Mn-superoxide dismutase modulates paraquat-mediated toxicity in mammalian cells FEBS 1991; 293:199-203.

36 Rahman IU, Massaro D. Endotoxin treatment protects rats against ozone-induced lung edema: With evidence for the role of manganese superoxide dismutase. Toxicol Appl Pharmacol 1992; 113:13-8.

37 Lautier D, Luscher P, Tyrrell RM. Endogenous glutathione levels modulate both constitutive and UVA radiation/hydrogen peroxide inducible expression of the human heme oxygenase gene. Carcinogenesis 1992; 13:227-32. 


\section{Persistent Induction of $c$-fos and $c$-jun Expression by Asbestos}

Nicholas H. Heintz*, Yvonne M. Janssen*, Brooke T. Mossman*‡

Department of Pathology*, University of Vermont College of Medicine, Soule Medical Alumni Building, Burlington VT 05405

University of Limburg ${ }^{\dagger}$, Maastricht, the Netheriands 


\section{Abstract}

To investigate the mechanisms of asbestos-induced carcinogenesis, expression of $c$-fos and $c$-jun protooncogenes was examined in rat pleural mesothelial cells and hamster tracheal epithelial cells after exposure to crocidolite or chrysotile asbestos. In contrast to phorbol-12-myristate 13-acetate, which induces rapid and transient increases in $c$-fos and $c$-jun mRNA, asbestos causes 2-5-fold increases in $c$-fos and $c$-jun mRNA that persist for at least $24 \mathrm{hrs}$ in mesothelial cells. The induction of $c$-fos and $c$-jun mRNA by asbestos in mesothelial cells is dose-dependent, and most pronounced with crocidolite, the type of asbestos most pathogenic in the causation of pleural mesothelioma. Induction of $c$-jun gene expression by asbestos occurs in tracheal epithelial cells, but is not accompanied by a corresponding induction of $c$-fos gene expression. In both cell types, asbestos induces increases in protein factors that bind specifically to the DNA sites that mediate gene expression by the AP-1 family of transcription factors. The persistent induction of AP-1 transcription factors by asbestos suggests a model of asbestos-induced carcinogenesis involving chronic stimulation of cell proliferation through activation of the early response gene pathway that includes $c$-jun and/or $c$-fos.

\section{Introduction}

Asbestos fibers are occupational carcinogens associated primarily with the development of lung cancers and malignant mesotheliomas (1). Several types of asbestos exist, most notably chrysotile $\left[\mathrm{Mg}_{6} \mathrm{Si}_{4} \mathrm{O}_{10}(\mathrm{OH})_{8}\right]$, a serpentine fiber that accounts for $>90 \%$ of the asbestos used industrially, and crocidolite $\left[\mathrm{Na}_{2}\left(\mathrm{Fe}^{3+}\right)_{2}\left(\mathrm{Fe}^{2+}\right)_{3} \mathrm{Si}_{8} \mathrm{O}_{22}(\mathrm{OH})_{2}\right]$, a rod-like, more durable amphibole fiber that is associated with a greater risk of pleural mesothelioma $(1,2)$.

The mechanisms of carcinogenesis by asbestos are unclear. In addition to fiber durability in the lung or pleura over the long latency period of tumor development, several properties of asbestos may contribute to its pathogenicity. Tumorigenic potential, cell transformation and chromosomal aberrations are more pronounced with long, thin fibers (generally $>5 \mu \mathrm{m}$ in length) in comparison to shorter fibers or particles of similar chemical composition $(3,4)$. Thus, fiber geometry and size may be critical determinants of fiber carcinogenicity. Other factors, such as the generation of active oxygen species (AOS) from redox reactions catalyzed on the fiber surface, or the release of AOS or growth factors from cells of the immune system, also may mediate the toxic or carcinogenic effects of asbestos (5).

Asbestos displays a variety of biological effects in different cell types. Human mesothelial cells are exquisitely sensitive to the cytotoxic effects of asbestos (6), 
and asbestos causes both chromosomal aberrations and morphological transformation in human (6) and rodent mesothelial cells (7). In fibroblasts (8) and epithelial cells (9), but not mesothelial cells (10), asbestos also enhances cell transformation by other agents such as polycyclic aromatic hydrocarbons. These results, and the lack of correlation between smoking history and the development of mesothelioma in humans (1), suggest that asbestos fibers may be complete carcinogens in the development of mesothelioma.

Asbestos, in comparison to cigarette smoke, is weakly carcinogenic in epithelial cells of the respiratory tract. In experimental models using rodent tracheal grafts, asbestos appears to act primarily as a cocarcinogen (11) or tumor promoter (12), perhaps by facilitating the uptake, metabolism and/or DNA binding of chemical carcinogens (13). Alternatively, asbestos causes chronic inflammation and may foster the development of tracheobronchial neoplasms by acting as a mitogen in a manner similar to the tumor promoter phorbol 12-myristate 13-acetate ("12-O-tetradecanoylphorbol-13-acetate," TPA) (1). At sublethal concentrations, chrysotile and crocidolite fibers cause proliferation of epithelial (14) and mesothelial cells (15). Crocidolite asbestos causes increased accumulation of diacylglycerol, hydrolysis of phosphatidylinositol and stimulation of protein kinase $\mathrm{C}$ (PKC) activity in hamster tracheal epithelial (HTE) cells $(16,17)$, suggesting that asbestos fibers initiate proliferation through second messenger pathways similar to those activated by TPA.

Among other events, activators of PKC, including TPA, induce the expression of AP-1, a family of accessory transcription factors that interact with regulatory DNA sequences known as TPA response elements (TREs) or AP-1 sites $(18,19)$. The family of AP-1 transcription factors that act through TREs includes homo- and heterodimeric protein complexes encoded by the $c$-fos and $c$-jun families of protooncogenes (19). In cell culture systems, expression of both $c$-fos and $c$-jun is required for transition of the G1 phase and entry into the $S$ phase of the cell cycle (18). By analogy to viral systems, Fos and Jun proteins are considered immediate early (or early response) gene products that regulate the expression of other genes required for progression through the cell cycle (18, 19).

Here we report the effects of crocidolite and chrysotile asbestos on the expression of $c$-fos and $c$-jun mRNA in rat pleural mesothelial (RPM) cells and a diploid HTE cell line, a progenitor cell type of bronchogenic carcinoma (20). Our results show that in RPM cells crocidolite asbestos is a potent and persistent inducer of $c$-fos and $c$-jun mRNA and AP-1 DNA binding activity. Although in HTE cells induction of $c$-jun mRNA by asbestos is not accompanied by coincidental increases in $c$-fos gene expression, increases in AP-1 DNA binding activity are observed. These studies suggest that asbestos may act as a mitogen in carcinogenesis by persistently activating the early response gene pathway. 


\section{Materials And Methods}

Asbestos fibers: Reference samples of National Institute of Environmental Health (NIEHS) processed crocidolite and chrysotile (Jeffrey Mines, Quebec) asbestos fibers were obtained from the Thermal Insulation Manufacturers Association (TIMA) Fiber Repository (Littleton, CO). Fiber numbers per unit weight of NIEHS chrysotile (courtesy of A. Wylie, University of Maryland) were $\approx 10$-fold greater than those for NIEHS processed crocidolite asbestos (courtesy of G. Hart, Schuller Mountain Technical Center, Littleton, CO) as calculated using data from scanning electron microscopy. Preparations of riebeckite, a nonfibrous particle similar chemically to crocidolite asbestos (21), and polystyrene beads (average diameter $1.05 \mu \mathrm{m}$, Polyscience) were used to assess the influence of fiber geometry on gene expression.

Cells and exposure to test agents: RPM cells were isolated from the parietal pleura of Fischer 344 rats by methods reported previously (22). Cells were propagated for four passages in F12 medium (GIBCO) containing $10 \%$ fetal bovine serum and hydrocortisone $(100 \mathrm{ng} / \mathrm{ml})$, insulin $(2.5 \mu \mathrm{g} / \mathrm{ml})$, transferrin $(2.5 \mu \mathrm{g} / \mathrm{ml})$ and selenium $(2.5 \mathrm{ng} / \mathrm{ml})$ (Sigma). HTE cells, isolated from the tracheal epithelium of a neonatal hamster (20), were propagated in F12 medium with $10 \%$ newborn bovine serum. Twenty-four hours prior to exposure of confluent cultures to test agents, the growth medium was replaced with medium containing $2 \%$ serum. Asbestos fibers and other particulates were suspended in Hank's Balanced Salt Solution (GIBCO) at $1 \mathrm{mg} / \mathrm{ml}$ and added directly to medium at final concentrations of 1.25 to $5.0 \mu \mathrm{g} / \mathrm{cm}^{2}$ area of dish. These concentrations of asbestos fibers were nontoxic to both cell types for at least 24 hrs as determined by total cellular protein (data not presented). TPA (Consolidated Midland, Brewster, NY) was added to medium at $100 \mathrm{ng} / \mathrm{ml}$ from a stock solution of $1 \mathrm{mg} / \mathrm{ml}$ in acetone. Untreated cultures were removed from the incubator and subjected to mock manipulations without changing the maintenance medium.

RNA isolation and Northern blot analysis: Total RNA was prepared and Northern blot hybridization was performed as described by Shull et al. (23). cDNA probes for human $c$-fos and $c$-jun were from Richard Gaynor (University of California, Los Angeles) and were labeled with $\left[\alpha-{ }^{32} \mathrm{P}\right] \mathrm{dATP}$ by random hexamer priming. Hybridization signals were quantified by measuring the radioactivity on blots either directly with a model 603 Betascope Analyzer (Betagen, Waltham, MA) or indirectly by densitometric analysis of autoradiographs with a Microscan Densitometer (Technology Resources, Inc., Nashville, TN). To ascertain the specificity of the $c$ - fos and $c$-jun response, Northern blots were rehybridized with a ${ }^{32} \mathrm{P}$-labeled cDNA probe for glyceraldehyde-3-phosphate dehydrogenase (GAPDH) (a gift from Ph. Jeanteur, Laboratoire de Biochimie, Centre Paul Lamarque, France). 
Gel mobility shift assays for AP-1 DNA binding activity: One nanogram of a ${ }^{32} \mathrm{P}$-end-labeled double-stranded oligodeoxynucleotide representing the fatspecific element (FSE) that contains a TRE consensus sequence (i.e., TGACTCA) (24) was incubated with $2 \mu \mathrm{g}$ of whole-cell extract $(0.5-2.0 \mathrm{mg}$ protein per $\mathrm{ml}$ ) in $40 \mathrm{mM}$ Hepes buffer, $\mathrm{pH} 7.8 / 80 \mathrm{mM} \mathrm{KCl}$ containing poly [d(I-C)] at $200 \mu \mathrm{g} / \mathrm{ml}$ in a total volume of $20 \mu \mathrm{l}$ for $20 \mathrm{~min}$ at room temperature. Whole cell extracts were prepared as described (25) except that final extract was not dialyzed. Protein/DNA complexes were resolved by electrophoresis in nondenaturing $4 \%$ polyacrylamide gels and visualized by autoradiography.

\section{Results}

To explore the effects of asbestos on the induction of early response genes, confluent cultures of RPM celis, were first exposed to crocidolite asbestos at a concentration that causes cell proliferation in vitro (14). At intervals from 30 min to $24 \mathrm{hr}$, total RNA was isolated for Northern blot analyses to ascertain the levels of $c$-fos and $c$-jun mRNA. In several experiments we compared $c$-fos and $c$-jun mRNA levels in cells treated with asbestos to the levels in untreated RPM cells and in cells exposed to TPA. In all groups, including untreated cultures not exposed to test agents, increased levels of $c$-fos and $c$-jun mRNA were observed at $30 \mathrm{~min}$ (Figure 1). Because the increases that occur by $30 \mathrm{~min}$ were similar in all groups, it is likely that these initial responses are nonspecific, as has been observed by others $(18,19)$. In comparison to controls, RPM cells treated with TPA yielded increased amounts of $c$-fos mRNA that reached peak levels after 1 $\mathrm{hr}$ and rapidly diminished to control levels thereafter (Figure 1, A and B). TPA induced a similar accumulation of $c$-jun mRNA in RPM cells; peak levels of $c$-jun mRNA were observed by $1 \mathrm{hr}$ after exposure and diminished thereafter (Figure 1, A and C). The induction of $c$-fos and $c$-jun by TPA in RPM cells was potentiated by cycloheximide (data not shown), suggesting that TPA induces a rapid and transient increase in the expression of $c$-fos and $c$-jun mRNA in RPM cells; such an increase is the hallmark of the early response gene pathway (18, 19).

In contrast, the kinetics of induction of $c$-fos and $c$-jun mRNA in RPM cells by asbestos differed from that observed with TPA. After $2 \mathrm{hr}$ of exposure to crocidolite fibers, the levels of $c$-fos and $c$-jun mRNA increased steadily for at least $24 \mathrm{hr}$ (Figure 1). Quantification of the Northern blot hybridization signals showed that at $24 \mathrm{hr}$ the levels of $c$-fos and $c$-jun mRNA in RPM cells exposed to crocidolite asbestos were 2-5-fold higher than those in control cultures or cultures treated with TPA (Figure 1, B and C). To determine whether the cellular responses leading to the accumulation of $c$-fos and $c$-jun mRNA were specific, we reprobed the Northem blots presented in Fig. 1 with a cDNA probe for the 


\section{A. $c$-fos}
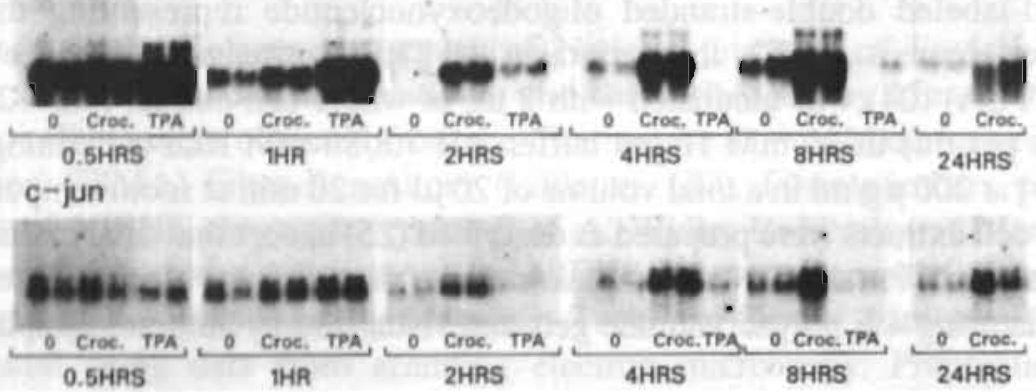

B. c-fos

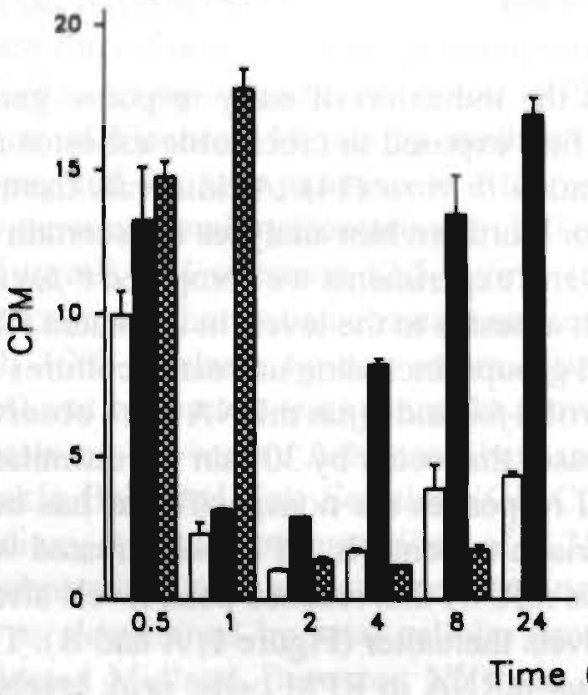

C. c-jun

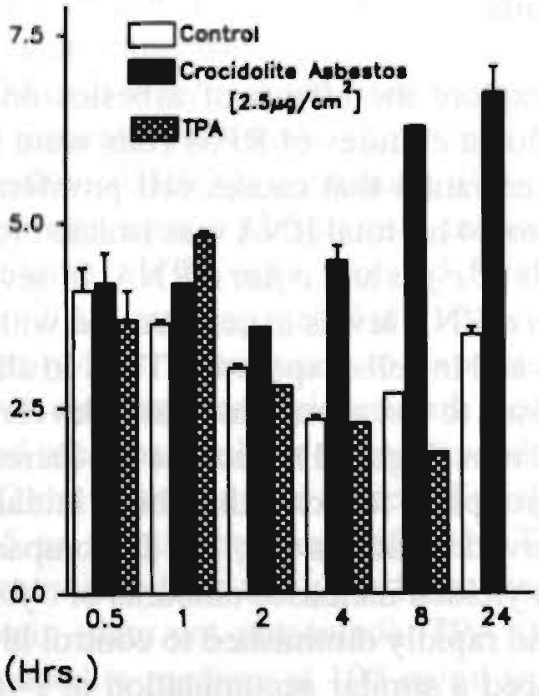

Figure 1. Persistent induction of $c$-fos and $c$-jun mRNA accumulation in confluent rat pleural mesothelial (RPM) cells after exposure to crocidolite (Croc.) asbesios. Total RNA was extracted from RPM cells at various times after treatment with the indicated agent and $12.5-\mu \mathrm{g}$ samples were analyzed by Northern blot hybridization to measure the relative steady-state levels of $c$-fos and $c$-jun mRNA $(A)$. The Northern blot hybridization signals for $c$-fos $(B)$ and $c$-jun $(C)$ were quantified with a Model 603 Betascope apparatus and are expressed in counts per minute. Each experimental point was performed in duplicate and the relative amounts of $m R N A$ are expressed as the mean \pm SEM.

"housekeeping" gene encoding GAPDH. In RPM cells, GAPDH mRNA levels varied $<15 \%$ between control and experimental groups.

To determine whether differences existed between responses of RPM cells to either crocidolite or chrysotile asbestos, cells were exposed to different doses of each fiber type for $8 \mathrm{hr}$, and the levels of mRNA encoding $c$-jun and $c$-fos were 


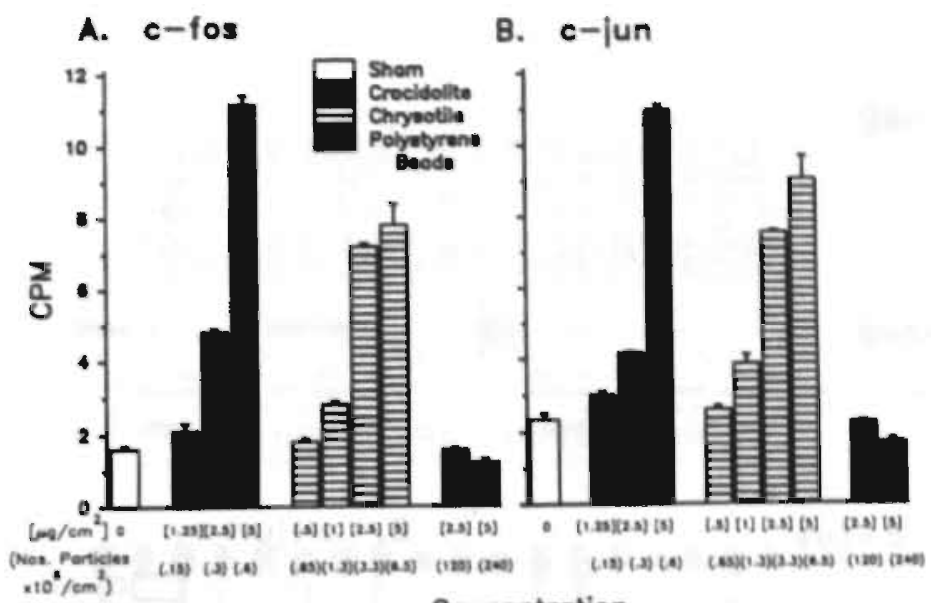

Concentration

Figure 2. Dose-response studies measuring steady-state levels of $c$-fos $m R N A$ (panel A) and c-jun mRNA (panel B) in RPM cells. Cells at confluence were exposed to NIEHS processed crocidolite or NIEHS chrysotile asbestos or polystyrene microspheres for $8 \mathrm{hr}$ and RIVA was isolated for Northern blot analyses. The hybridization signals for $c$-fos and c-jun mRNA were quantitated directly with a Model 603 Betascope. Data are expressed as mean cpm \pm SEM $(n=2$ lanes per group). Concentrations of particulates on the abscissa are expressed as micrograms and corresponding numbers of fibers or polystyrene particles (per unit weight) per $\mathrm{cm}^{2}$ surface area of dish.

measured by quantitative Northern blot analysis. Both crocidolite and chrysotile asbestos caused dose-dependent, persistent increases in $c$-fos and $c$-jun mRNA (Figure 2, A and B). When the response is evaluated as a function of fiber mass (microgram of particulate per unit area) these two fiber types appear similar in their ability to induce $c$-fos and $c$-jun gene expression. However, if the dose is evaluated as a function of the number of fibers per unit area (as there are more chrysotile than crocidolite fibers per unit mass), crocidolite asbestos is a more potent inducer of $c$-fos and $c$-jun mRNA expression in RPM cells than is chrysotile asbestos. Increases in $c$-fos and $c$-jun mRNA were not observed with polystyrene beads (Figure 2) or with riebeckite (data not shown) at a range of particle concentrations. We next asked whether asbestos induces $c$-fos and $c$-jun mRNA in HTE cells. Like RPM cells, untreated HTE cultures and cultures exposed to asbestos displayed rapid and nonspecific increases in both $c$-fos and c-jun mRNA levels at 30 min (Figure 3). After 30-min exposure to TPA, HTE cells exhibited $c$-fos mRNA levels 4-to 5-fold greater than those observed in control cells (Figure 3, B). In contrast to RPM cells, elevated levels of $c$-fos mRNA were not observed in HTE cells at any later time after treatment with TPA, chrysotile, or crocidolite asbestos (Figure 3, B). The c-jun response in 


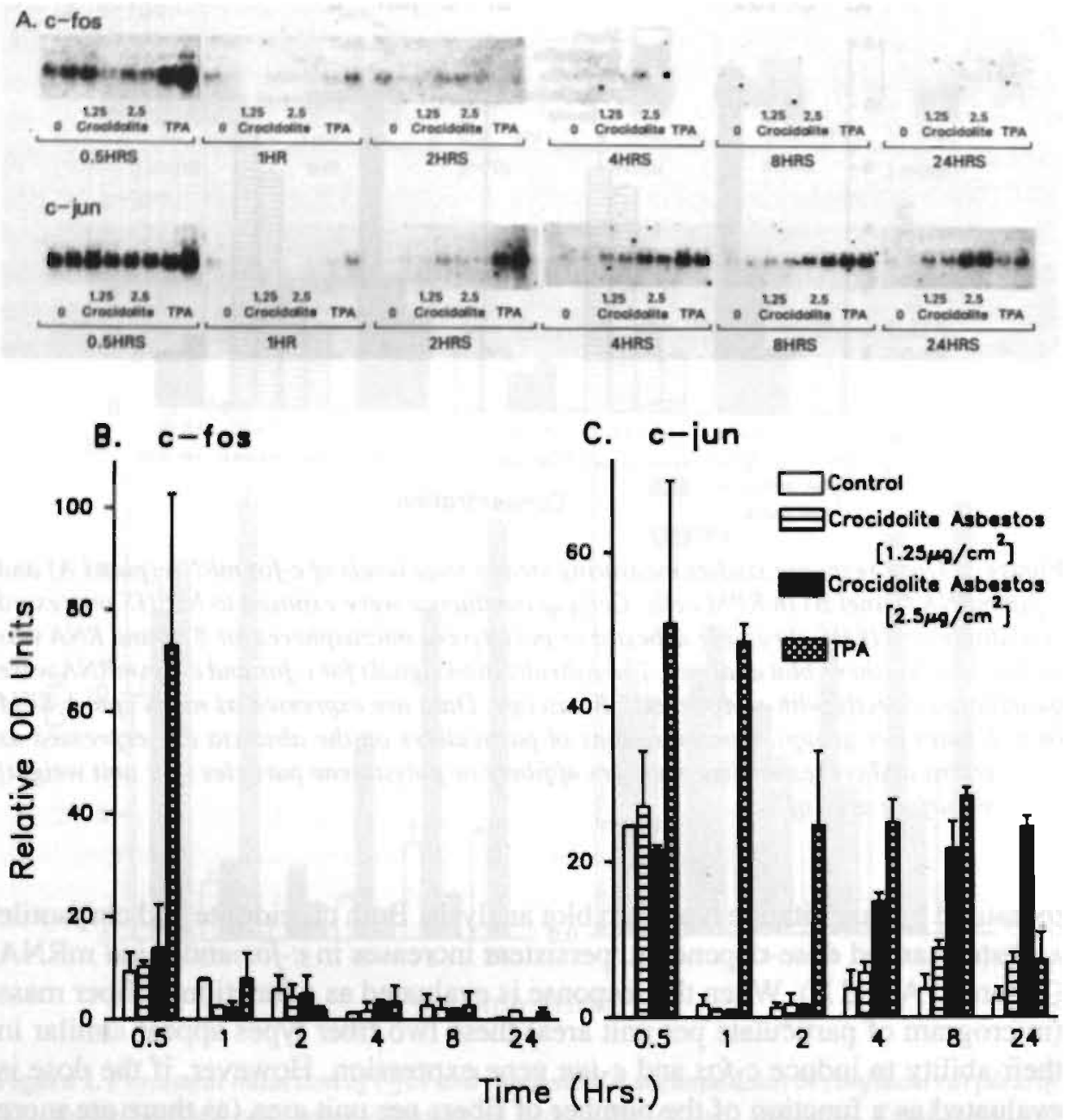

Figure 3. Time course of $c$-fos and $c$-jun mRNA accumulation in HTE cells after exposure to TPA or asbestos. HTE cells were treated with TPA or crocidolite asbestos and total RNA was prepared for Northern blot analyses $(A)$ as described in Figure 1. The relative amounts of $c-f o s(B)$ and $c$-jun $(C)$ mRNA were determined by densitometric analysis of autoradiographs and are expressed as the mean $\pm S E M$ in arbitrary optical density $(O D)$ units.

HTE cells also differed from that observed in RPM cells. In HTE cells, the accumulation of $c$-jun mRNA in response to TPA occurred rapidly but persisted for $4-8 \mathrm{hr}$ before falling to control levels at $24 \mathrm{hr}$. With crocidolite asbestos, elevated levels of $c$-jun mRNA were first observed $4 \mathrm{hr}$ after addition of fibers and increased steadily for at least $24 \mathrm{hr}$. These results clearly show that 


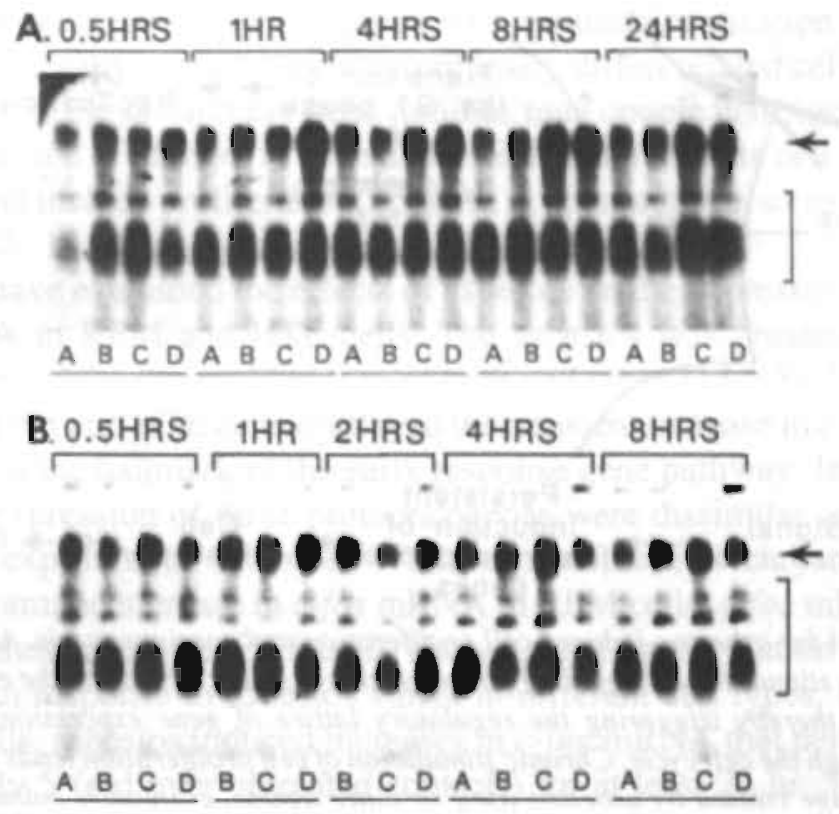

Figure 4. Induction of AP-1 transcription factors in RPM cells (panel A) or HTE cells (panel $B)$ by TPA and crocidolite asbestos. Gel mobility-shift assays were used to assess the relative amounts of protein factors that bind specifically to the TREs. Whole cell extracts from untreated cells (lanes A) or cells exposed to crocidolite asbestos at 1.25 or $2.5 \mu \mathrm{g} / \mathrm{cm}^{2}$ (lanes $B$ and $C$, respectively) or to TPA at $100 \mathrm{ng} / \mathrm{ml}$ (lanes D) were incubated with an end-labeled probe (FSE) containing a consensus TRE. Protein-DNA complexes were resolved by nondenaturing gel electrophoresis and visualized by autoradiography. The specific AP-1/FSE DNA complex is indicated by an arrow; nonspecific protein-DNA complexes are indicated by a bracket.

crocidolite asbestos induces elevated levels of mRNA for early response gene products that persist for at least $24 \mathrm{hr}$. Moreover they indicate that the regulation of $c$-fos mRNA levels in response to asbestos differs in HTE and RPM cells. In HTE cells, the levels of GADPH mRNA varied less than $5 \%$ between control and test groups (data not shown).

We used gel mobility shift assays to ascertain whether the induction of $c$-fos and/or $c$-jun mRNA was accompanied by increased levels of AP-1 transcription factors. Whole cell extracts from treated and untreated cells were incubated with a radiolabeled probe (FSE) containing the consensus sequence for AP-1 DNA binding, and the resulting protein/DNA complexes were resolved in neutral polyacrylamide gels (24). Induction of $c$-fos and $c$-jun mRNA in RPM cells by asbestos was accompanied in time by increased levels of protein factors that bound specifically to the AP-1 sequence (Figure 4). Note that the protein/AP-1 DNA complexes induced by TPA and asbestos comigrated and that after $24 \mathrm{hr}$, 


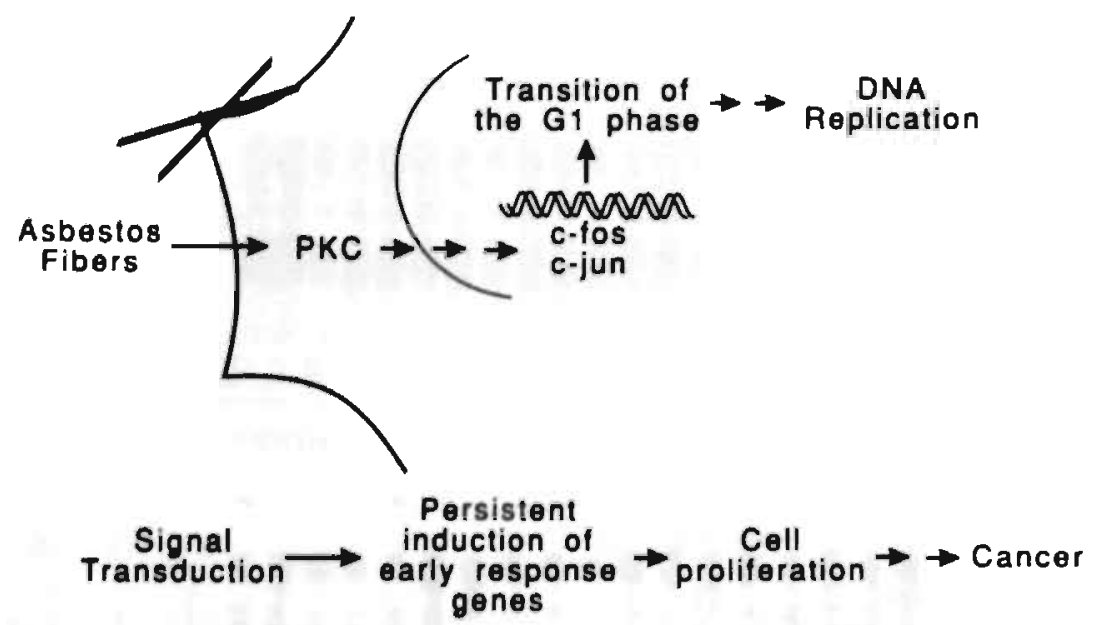

Figure 5. Model for asbestos-induced cell proliferation and carcinogenesis. Asbestos fibers are proposed to stimulate cell signaling pathways that result in activation the early response gene pathway, thereby triggering the regulatory lattice of gene expression required for transition through the cell cycle. Chronic stimulation of cell proliferation leads to the fixation of genetic damage caused by asbestos itself or other agents, eventually culminating in the selection of neoplastic cells.

the level of AP-1 DNA binding activity induced by asbestos was about twice that observed with TPA (Figure 4, A). Using a variety of specific and nonspecific competitors, as well as purified c-Fos and c-Jun proteins, we have demonstrated that the protein/AP-1 DNA complex induced by asbestos comigrates with that produced by c-Fos/c-Jun heterodimers (data not shown). Although we have not observed induction of $c$-fos mRNA in HTE cells by asbestos, exposure of HTE cells to asbestos fibers is accompanied by increases in protein factors that bind specifically to the AP-1 DNA consensus sequence (Figure 4, B). The induction of AP-1 binding activity in HTE cells may result from the induction of Fral or another Fos-related gene product that is able to dimerize with c-Jun (26).

\section{Discussion}

The $c$-fos and $c$-jun genes are members of multigene families that are transiently expressed in response to a wide variety of environmental cues in both proliferating and nonproliferating cells $(18,19)$. Both homodimeric complexes of the jun gene-family products and heterodimeric complexes of the jun and fos genefamily products are able to bind a series of related DNA sequences and thereby modulate transcription. Although fos and jun have been implicated in the 
regulation of cell growth in vitro and in vivo, immunolocalization studies show that Fos is expressed at high levels in terminally differentiated cells (27). Thus, the members of the fos and jun gene families may couple cell signalling events at the cell surface to changes in gene expression that modulate cell-type-specific responses that include proliferation, changes in phenotype, or even programmed cell death $(18,19,27)$.

Here we have examined the effects of asbestos on the expression of $c-f o s$ and $c$-jun mRNA in RPM and HTE cells. The asbestos was present at sublethal amounts that induce the proliferation of both cell types $(14,15)$. In response to TPA, both RPM and HTE cells displayed the transient increase in $c$-fos and $c$-jun mRNA that is the hallmark of the early response gene pathway. In contrast, the patterns of expression of these protooncogenes were dissimilar in the two cell types after exposure to asbestos. While crocidolite and chrysotile asbestos induced a dramatic increase in $c$-fos mRNA in RPM cells, $c$-fos mRNA was not induced by these agents in HTE cells, showing that the regulation of $c$-fos gene expression in response to asbestos varies in different cell types. In both RPM and HTE cells, asbestos induced increases in $c-j u n ~ m R N A$ that persisted at high levels (nearly 5 -fold over untreated controls) for at least $24 \mathrm{hr}$. The persistent induction of $c$-jun and/or $c$-fos mRNA is significant, as induction of transcription by AP-1 binding proteins requires sustained expression of these factors (28).

The induction of gene expression in RPM cells by asbestos is dose-dependent and not observed with polystyrene beads (Figure 2) or riebeckite (data not shown), nonfibrous and noncarcinogenic particles which do not induce proliferation in cell or organ cultures $(14,21)$. These data suggests that fiber geometry is a critical determinant in the sustained induction of $c$-fos and $c$-jun transcription and/or mRNA stabilization.Our results suggest a model for the induction of neoplastic disease by asbestos (Figure 5). By persistently activating the early response gene pathway, asbestos may induce chronic cell proliferation that subsequently contributes to carcinogenesis in lung and pleura $(29,30)$. The model is consistent with data that show increases in diacylglycerol and stimulation of PKC precede asbestos-induced cell replication $(16,17)$. Here we have shown that these cell signaling responses are accompanied by the accumulation of $c$-jun and/or $c$-fos mRNA and the concomitant formation of AP-1 transcription factors that bind specific regulatory DNA sequences. Based on studies in other systems $(18,19)$, we suggest these early gene responses are representative of the events that initiate progression through the cell cycle. Durable asbestos fibers may therefore provide a persistent growth stimulus during long latency periods of tumors and thereby contribute to the eventual fixation of genetic changes caused by asbestos itself or other agents. Alternatively, induction of $c$-fos and $c$-jun may affect changes in cell phenotype that contribute to neoplastic transformation. 
It is noteworthy that the accumulation of $c$-jun and/or c-fos mRNA occurs in RPM and HTE cells in the absence of intermediary cells of the immune system. This suggests that growth factors or other substances released from immune cells are not required to elicit the early gene response by asbestos fibers. Rather, our data suggest that the induction of chronic cell proliferation may be an inherent property of asbestos fibers. Thus, both an enhanced capacity to activate the early response gene pathway and pronounced biopersistence may be critical factors in the increased pathogenicity of crocidolite as compared to chrysotile asbestos $(1,2)$.

\section{Acknowledgements}

We thank Richard Gaynor for the $c$-fos and $c$-jun plasmids used in the Northern blot analysis, and Drs. Paul Borm, John E. Craighead, and J. Bernard L. Gee for helpful comments. This work was supported by grant \#HL 14212 from the National Institutes of Health and a grant from the Environmental Protection Agency. 


\section{REFERENCES}

1. Mossman, B.T., Bignon, J., Corn, M., Seaton, A. \& Gee, J.B.L. (1990) Science 247:294301.

2. Doll, R. (1989) in Non-Occupational Exposure to Mineral Fibres, eds. Bignon, J. Peto, J., Saracchi, R. (International Agency for Research on Cancer, Lyon, France), pp. 511-518.

3. Davis, J.M.G., Addison, J., Bolton, R.E., Donaldson, K., Jones, A.D. \& Smith, T. (1986) Br. J. Exp. Path. 67:415-430.

4. Hesterberg, T.W. \& Barrett, J.C. (1984) Cancer Res. 44:2170-2180.

5. Mossman, B.T. \& Marsh, J.P. (1991) in Cellular and Molecular Aspects of Fiber Carcinogenesis, eds. Harris, C.C., Lechner, J.F., Brinkley, B.R. (Cold Spring Harbor Press, Cold Spring Harbor, pp. 159- 168.

6. Lechner, J.F., Tokiwa, T., LaVeck, M., Benedict, W.F. Banks-Schlegel S., Yeager H., Jr., Banerjee, A. \& Harris, C.C. (1985) Proc. Natl. Acad. Sci. U.S.A. 82:3884-3888.

7. Jaurand, M.C., Kheung L., Magne L. \& Bignon J. (1986) Mutat. Res. 169: 141-148.

8. Hei, T.K., Geard, C.R., Osmak, R.S. \& Travisano, M. (1985) Br.J. Cancer. 52:591-597.

9. Reiss, B., Tong, C., Telany, S. \& Williams, G.M. (1983) Environ. Res. 31:100-104.

10. Paterour, M.J., Bignon, J. \& Jaurand, M.C. (1985) Carcinogenesis 6:523-529.

11. Mossman, B.T. \& Craighead, J.E. (1979) in Prog. Exptl. Tumor Res. ed. Homburger, F.(S. Karger, Basel), pp. 37-47.

12. Topping, D.C. \& Nettesheim, P. (1980) J. Natl. Cancer Inst. 65:627-630.

13. Eastman, A., Mossman, B.T. \& Bresnick, E. (1983) Cancer Res. 43:1251-1255.

14. Marsh, J.P. \& Mossman, B.T. (1988) Cancer Res. 48:709-714.

15. Rajan, K.T., Wagner, J.C. \& Evans, P.H. (1972) Nature 238:346-347.

16. Sesko, A.M., Cabot, M. \& Mossman, B.T. (1990) Proc. Natl. Acad. Sci. U.S.A. 87:7385-7389.

17. Perderiset, M., Marsh, J.P. \& Mossman, B.T. (1991) Carcinogenesis 12:1499-1502.

18. Angel, P. \& Karin, M. (1991) Biochim. Biophys. Acta 1072:129-157.

19. Ransone, L.J. \& Verma, I.M. (1990) Annu. Rev. Cell Biol. 6:539-557.

20. Mossman, B.T., Ezerman, E.B., Adler, K.B. \& Craighead, J.E. (1980) Cancer Res. 40:4403-4408.

21. Woodworth, C.D., Mossman, B.T. \& Craighead, J.E. (1983) Cancer Res. 43:4906-4912.

22. Jaurand, M.C., Bastie-Sigeac, J., Bignon, J. \& Stoebner, P. (1983) Environ. Res. 30:255-269.

23. Shull, S., Heintz, N.H., Periasamy, M., Manohar, M., Janssen, Y.M.W., Marsh, J.P. \& Mossman, B.T. (1991) J. Biol. Chem. 266:24398-24403.

24. Rauscher, F.J. III, Sambucetti, L.C., Curran, T., Distel, R.J., and Spiegelman, B.M. (1988) Cell 52:471-480.

25. Raychaudhuri, P., Rooney, R., \& Nevin, J.R. (1987) EMBO J. 6:4073-4081.

26. Cohen, D.R., Ferreira, C.P., Gentz, R., Franza, B.R. \& Curran, T. (1989) Genes Dev. 3:173-184.

27. Demoly, P., Basset-Seguin, N., Chanez, P., Campbell, A.M., Gauthier-Rouviere, C., Godard, P., Michel, F.B. \& Bousquet J. (1992) Am. J. Respir. Cell. Mol. Biol. 7:128-133.

28. Trejo, J., Chambard, J.-C, Karin, M. \& Brown, J.H. (1992) Molec. Cell. Biol. 12:47424750.

29. Ames, B.N. \& Gold, L.S. (1990) Science 249:970-971. 
30. Preston-Martin, S., Pike, M.C., Ross, R.K., Jones, P.A. \& Henderson, B.E. (1990) Cancer Res. 50:7415-7421. 


\section{Expression of $c$-fos and $c$-jun Protooncogenes in Rodent Pleural Mesothelial Cells and Tracheal Epithelial Cells after Exposure to Asbestiform Fibers and Particulates}

Yvonne M.W. Janssen, Nicolas H. Heintz, Joanne P. Marsh, Paul J.A. Borm and Brooke T. Mossman.

Department of Pathology, University of Vermont College of Medicine, Burlington VT 10405, U.S.A. and the Department of Health Risk Analysis and Toxicology, University of Limburg, Maastricht, The Netherlands. 


\section{ABSTRACT}

Occupational exposure to asbestos can lead to development of pulmonary fibrosis, bronchogenic carcinoma, or mesothelioma, diseases resulting from aberrant proliferation. To study mechanims of proliferation, we examined mRNA expression of $\mathrm{c}-f o s$ and c-jun protooncogenes in rodent tracheal epithelial cells (HTE) and pleural mesothelial cells (RPM), the progenitor cells of bronchogenic carcinoma and mesothelioma, respectively, after exposure to a number of different fibrous materials or particles to determine the properties of particulates important in protooncogene induction. In addition, mRNA levels of ornithine decarboxylase (ODC) were measured comparatively as a marker of proliferation. In comparison to crocidolite asbestos, less striking increases in c-jin mRNA were observed in HTE cells after exposure to man made vitreous fiber-10 (MMVF-10) or refractory ceramic fiber-1 (RCF-1). No c-fos mRNA was detected in HTE cells after exposure to fibers, at all timeperiods tested. Increases in mRNA levels of ODC were observed in HTE cells after exposure of all fibers tested. Exposure of HTE cells to the active oxygen species (AOS), $\mathrm{H}_{2} \mathrm{O}_{2}$ caused striking increases in mRNA levels of both c-fos and c-jun which preceded increases in ODC mRNA. In RPM cells, crocidolite asbestos caused increases in mRNA levels of c-fos and c-jun that were more striking in comparison to MMVF-10 or RCF-1. However, erionite, a fiber extremely potent in the causation of mesothelioma in man, caused more striking increases in c-fos and c-jun mRNA in comparison to asbestos. Nonfibrous particles did not alter protooncogene expression in these cell types suggesting that the fibrous geometry of particulates is critical in the induction of c-fos and c-jun protooncogenes.

\section{INTRODUCTION}

Asbestos is a family of fibrous mineral silicates which possess great tensile strength, flexibility and heat resistance. Asbestos fibers are subdivided into two families; serpentine asbestos, with chrysotile asbestos as its only member, and amphibole asbestos, a family which contains crocidolite and several other fibers (1). Inhalation of asbestos fibers can lead to inflammation and a variety of malignant and non-malignant pulmonary disorders depending upon the extent of exposure and the type of asbestos that is inhaled. Most notably, inhalation of amphibole asbestos is more apt to give rise to bronchogenic carcinoma and mesothelioma, malignant diseases with average latency periods of 20 or more years and $35-40$ years, respectively (1). 
A hallmark of asbestos exposure is an inflammatory process elicited at the site of injection or after inhalation of fibers into the lung. Since asbestos causes chronic inflammation by elaboration of active oxygen species (AOS) and/or growth factors (2), it may act as a mitogen in the development of tracheobronchial neoplasms or mesothelioma, similar to the tumor promoter, 12-O-tetradecanoylphorbol-13-acetate (TPA), applied on mouse skin (3). Studies showing increased accumulation of diacylglycerol, hydrolysis of phosphatidylinositol (4), and stimulation of protein kinase C (PKC) activity (5) after exposure to asbestos, also suggest that second messenger pathways triggered at the surface of the cell by asbestos might be similar to those activated by TPA.

Cell signaling events triggered by asbestos or the tumor promoter, TPA, can lead to cell proliferation. For instance, in tracheal epithelial cells, asbestos and TPA cause induction of ornithine decarboxylase (ODC) (6), a rate limiting enzyme in biosynthesis of polyamines, compounds required for cell proliferation, and involved in tumor promotion $(7,8)$. Studies employing different preparations of fibrous and non-fibrous particulates imply that fibrous nature is important in induction of ODC and cell proliferation (9). Moreover, AOS appear to be involved in the elevation of ODC activity caused by asbestos (6). For example, addition of generating systems of AOS to tracheal epithelial cells in vitro, causes increases in gene expression and enzyme activity of ODC in a fashion similar to asbestos. Increases in ODC mRNA levels and enzymatic activity by asbestos also can be prevented in cells exposed simultaneously to scavengers of AOS (6). Thus, in addition to their involvement in cell and tissue damage (10), AOS also appear to mediate cell proliferation induced by asbestos.

Several studies have shown that agents inducing PKC also lead to induction of c-fos and c-jun protooncogenes. c-fos and c-jun are immediate early genes involved in transition of the Gl phase and entry into the $S$ phase of the cell cycle. Moreover, members of the fos and jun gene family can dimerize to form the transcription factor, AP-1 (11). The tumor promoter, TPA, has served as a model system to investigate gene expression of members of the fos and jun gene family and causes a characteristic pattem of induction of these protooncogenes. Since asbestos exposure appears to trigger some of the same cell signaling pathways as TPA, we were interested in whether asbestos could increase gene expression of members of the fos/jun gene families. Recently, we have demonstrated that asbestos causes prolonged induction of c-fos and c-jun gene expression in hamster tracheal epithelial (HTE) cells and rat pleural mesothelial (RPM) cells, the progenitor cells of bronchogenic carcinoma and mesothelioma, respectively (12). In comparison to TPA, induction of c-fos and c-jun mRNA levels in HTE or RPM cells after exposure to asbestos was delayed, but more persistent. 
Interestingly, differences in patterns of $\mathrm{c}-\mathrm{f}$ fos and $\mathrm{c}-\mathrm{jun}$ gene expression were observed in the different cell types. For example, asbestos induced c-jun gene expression in both RPM and HTE cells. However, no induction of c-fos was observed in HTE cells. In RPM cells, asbestos caused dramatic increases in mRNA levels of both c-fos and c-jun. Furthermore, induction of both protooncogenes was most pronounced with crocidolite, the type of asbestos most pathogenic in the induction of mesothelioma, in comparison to chrysotile asbestos. No alterations in mRNA levels of c-fos and c-jun were reported in RPM cells after exposure to polystyrene beads, a non-carcinogenic particulate control. These studies indicate that prolonged induction of $c-f o s$ and c-jun protooncogene expression can lead to chronic stimulation of cell proliferation and provide a model of asbestos-induced carcinogenesis (12).

Asbestos minerals have multiple applications in a variety of industrial and domestic settings. Due to the documented carcinogenicity of asbestos, alternative fibers are being tested and developed by industry. Many of these naturally occurring and synthetic substitutes are fibers (i.e possess a length to diameter ratio $>3: 1$ ), but differ from various types of asbestos in their chemical and physical characteristics. Although some of these fibers have been extensively studied for fibrogenic or carcinogenic effects in chronic inhalation studies in laboratory animals, others have been poorly characterized for their ability to elicit pulmonary disease (13). Due to the long latency periods of asbestos-induced tumors, short term bioassays are needed to study the biological effects of mineral dusts on cells in culture $(14,15)$.

In the present study, we investigated the potency of different natural and synthetic fibers, and a non-fibrous analog of asbestos, to induce c-fos and c-jun protooncogenes in hamster tracheal epithelial (HTE) and rat pleural mesothelial (RPM) cells. The goal of the present work was; i) to investigate whether induction of $c-j u n$ and/or c-fos in these cell types occurred after exposure to non-asbestos fibers; ii) to compare different preparations of fibers to determine whether patterns of c-fos and c-jun protooncogene induction are similar, and; iii) to establish an in vitro model to predict the potential carcinogenicity of fibers. Since AOS are important mediators of asbestos-incuced toxicity and cell proliferation, we were also interested in determining whether the AOS, hydrogen peroxide $\left(\mathrm{H}_{2} \mathrm{O}_{2}\right)$ could induce $c-f o s$ and $c-j u n$ protooncogenes in a fashion similar to asbestos. In addition, we measured mRNA expression of ODC as an indicator of cell proliferation to determine whether a relationship exists between increases in mRNAs for c-jun and/or c-fos protooncogenes and mRNA levels of ODC. 


\section{MATERIALS AND METHODS}

Mineral fibers and particulates: Reference samples of National Institute of Environmental Health Sciences (NIEHS) processed crocidolite and chrysotile asbestos fibers were obtained from the Thermal Insulation Manufacturers Association Fiber Repository (T.I.M.A., Littleton,CO). Man Made Vitreous Fiber10 (MMVF-10) and Refractory Ceramic fiber-1 (RCF-1) were also provided by T.I.M.A. Erionite form Rome, Oregon was obtained from Dr. Reg Davies (MRC Pneumoconiosis Unit, Penarth, Wales)(16). Riebeckite, a non-fibrous analog chemically identical to crocidolite asbestos (6) and polystyrene beads (Polysciences Inc., Warrington, PA)(12) were used as a particulate controls. The physical characteristics of fibers and particles are described in Table 1.

TABLE I Physical characterization of fibers and particulates

\begin{tabular}{lll}
\hline & $\begin{array}{l}\text { Mean diameter } \\
\mu \mathrm{m}\end{array}$ & $\begin{array}{l}\text { Mean length } \\
\mu \mathrm{m}\end{array}$ \\
\hline Crocidolite $^{\mathrm{a}}$ & 0.27 & 11.4 \\
Chrysotile $^{\mathrm{a}}$ & 0.08 & 1.1 \\
MMVF-10 $^{\mathrm{b}}$ & 1.36 & 19.8 \\
RCF-1b $^{\mathrm{b}}$ & 1.07 & 24.0 \\
Polystyrene beads $^{\mathrm{a}}$ & 1.05 & - \\
Riebeckite (34) $_{\text {Erionite (27) }}^{0.8^{\mathrm{c}}}$ & - \\
\hline
\end{tabular}

${ }^{a}$ Results obtained by scanning electron microscopy (12); bata obtained by phase contrast light microscopy (Dr. G. Hart, Mountain Technical Center, Littleton, CO., personal communication); ${ }^{\mathrm{c}}$ Median values.

Cell culture: HTE cells, isolated from tracheal epithelium of a neonatal hamster (17), were propagated in F12 medium containing $10 \%$ newborn bovine serum (GIBCO). RPM cells were isolated from the parietal pleura of Fisher 344 rats as described elsewhere (18). Cells were maintained and passaged in F12 medium containing $10 \%$ fetal bovine serum (GIBCO), $100 \mathrm{ng} / \mathrm{ml}$ hydrocortisone, 2.5 $\mu \mathrm{g} / \mathrm{ml}$ insulin, $2.5 \mu \mathrm{g} / \mathrm{ml}$ transferrin, and $2.5 \mathrm{ng} / \mathrm{ml}$ selenium (Sigma). Cells were grown to confluence and 24 hours prior to addition of mineral dusts, the growth medium was replaced with medium containing $2 \%$ serum. Mineral dusts were sterilized at $225^{\circ} \mathrm{F}$ for 12-15 hours, suspended in Hank's Balanced Salt Solution (GIBCO) at $2 \mathrm{mg} / \mathrm{ml}$, sonicated for 4 minutes in a sonicator bath, and triturated $8 \mathrm{X}$ though a 22 gauge needle, as described previously (6). Fibers were added 
directly to the medium at final concentrations of $1.25-25 \mu \mathrm{g} / \mathrm{cm}^{2}$ area of dish. Hydrogen peroxide $\left(\mathrm{H}_{2} \mathrm{O}_{2}\right)$ was diluted in phosphate buffered saline ( $\mathrm{pH} 7.4$ ) and added to the cell culture medium directly.

RNA isolation and Northern blot analysis: Total RNA was extracted from cells according to the method of Chomszynski and Sacchi (19) and used in Northern blot Hybridization (20). c-fos, c-jun, and ODC cDNAs were labeled with $\left[\alpha-{ }^{32} \mathrm{P}\right] \mathrm{dATP}$ by random hexamer priming as described elsewhere (12). Hybridization signals were quantitated by measuring the radioactivity on blots directly with a model 603 Betascope (Betagen, Waltham, MA) or indirectly by densitometric analysis of the autoradiographs (Protein and DNA Imageware Systems, Huntington Station NY). Representative blots were reprobed with a $\left[{ }^{32} \mathrm{P}\right]$-labeled cDNA probe encoding glyceraldehyde-3-phosphate dehydrogenase (GAPDH) to ascertain the consistency of RNA contents of blots. c-fos and c-jun plasmids were obtained from R. Gaynor (University of California, Los Angeles). A cDNA encoding ODC was generously provided by $\mathrm{P}$. Coffino (Chiron Corp, Emeryville, CA)(21). A GAPDH cDNA-containing plasmid was a gift from P. Jeanteur, Laboratoire de Biochimie, Centre Paul Lamarque, France.

\section{RESULTS}

Figure 1 shows the time course of gene expression of c-fos and c-jun in HTE cells after $2,4,8$, and 24 hours of exposure to crocidolite asbestos or $\mathrm{H}_{2} \mathrm{O}_{2}$. In HTE cells exposed to asbestos, increases in mRNA levels of c-jun are apparent after 4 hours of exposure with maximum increases at 24 hours (Figure 1B). However, no alterations in steady state mRNA levels of c-fos are observed in this cell type after exposure to asbestos at any time points studied (Figure 1A). In contrast, exposure of HTE cells to $100 \mu \mathrm{M}$ of $\mathrm{H}_{2} \mathrm{O}_{2}$ caused dramatic increases in mRNA levels of both c-fos and c-jun. After 2 hours of exposure, c-fos and c-jun steady state mRNA levels were highest, decreasing to control levels after 24 hours of exposure. No alterations in c-fos mRNA and only moderate increases in c-jun gene expression were observed in HTE cells after exposure to $10 \mu \mathrm{M}$ of $\mathrm{H}_{2} \mathrm{O}_{2}$.

As described in experiments above, no elevations in c-fos mRNA were detected after exposure of HTE cells to asbestos, whereas striking increases were apparent after exposure to $100 \mu \mathrm{M}$ of $\mathrm{H}_{2} \mathrm{O}_{2}$ (Figure 2A). Dose dependent increases in c-jun mRNA levels were observed in HTE cells following graded increases of either crocidolite or chrysotile asbestos (Figure 2B). Increases in c-jun mRNA levels were most pronounced with crocidolite asbestos when compared to 
A. $\mathrm{c}-\mathrm{fos}$

2 HAS

4 HAS

a HAS

24 HAS

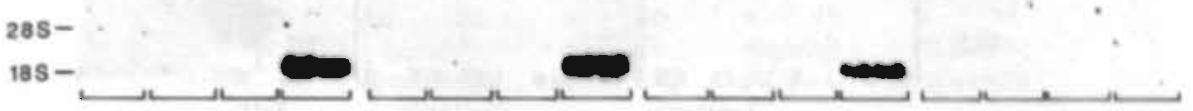

B. c-jun
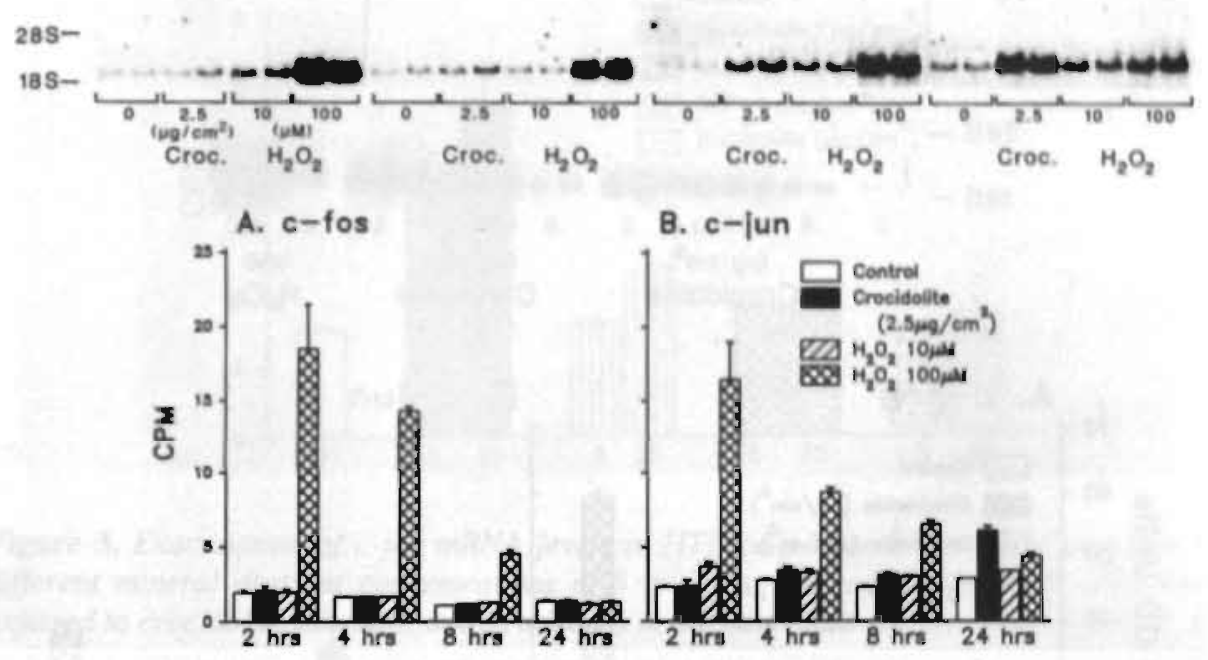

Figure 1. Time course of $c$-fos $(A)$ and $c$-jun $(B)$ mRNA levels in HTE cells after exposure to asbestos or $\mathrm{H}_{2} \mathrm{O}_{2}$. HTE cells were grown to confluence and switched $102 \%$ serum containing medium 24 hours prior to addition of test agents. Crocidolite asbestos, suspended in HBSS was added directly to the medium at a final concentration of $2.5 \mu \mathrm{g} / \mathrm{cm}^{2}$ area dish whereas $\mathrm{H}_{2} \mathrm{O}_{2}$ was added to medium in a final concentration of 10 or $100 \mu \mathrm{M}$. After 2, 4, 8, and 24 hours of exposure, total RNA was extracted and Northern blot analysis performed. Blots were hybridized with ${ }^{32} P$-labeled $c D N A$ probes encoding $c$-fos or $c$-jun. Hybridization signals were quantitated directly on a Betascope and results are expressed in cpm (mean + S.E.M.).

chrysotile asbestos, especially when evaluated as a function of fiber numbers per area of dish (see bottom panel Figure 2B). To evaluate whether induction of c-jun mRNA levels was observed specifically after exposure to asbestos fibers, we exposed HTE cells to a variety of fiber types or particles for 24 hours, the time period of maximal response of c-jun mRNA after asbestos exposure (12). As shown in Figure 3, exposure of HTE cells to 5 or $25 \mu \mathrm{g} / \mathrm{cm}^{2}$ crocidolite asbestos for 24 hours caused 2-3 fold increases in c-jun mRNA levels. Examination of MMVF-10 and RCF-1 fibers at equal mass concentrations of fibers, revealed less striking ( $<2$ fold) increases in mRNA levels of $c-j u n$. In addition, 


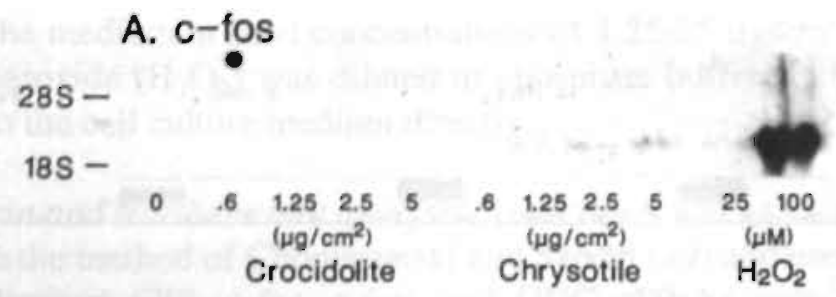

B. c-jun
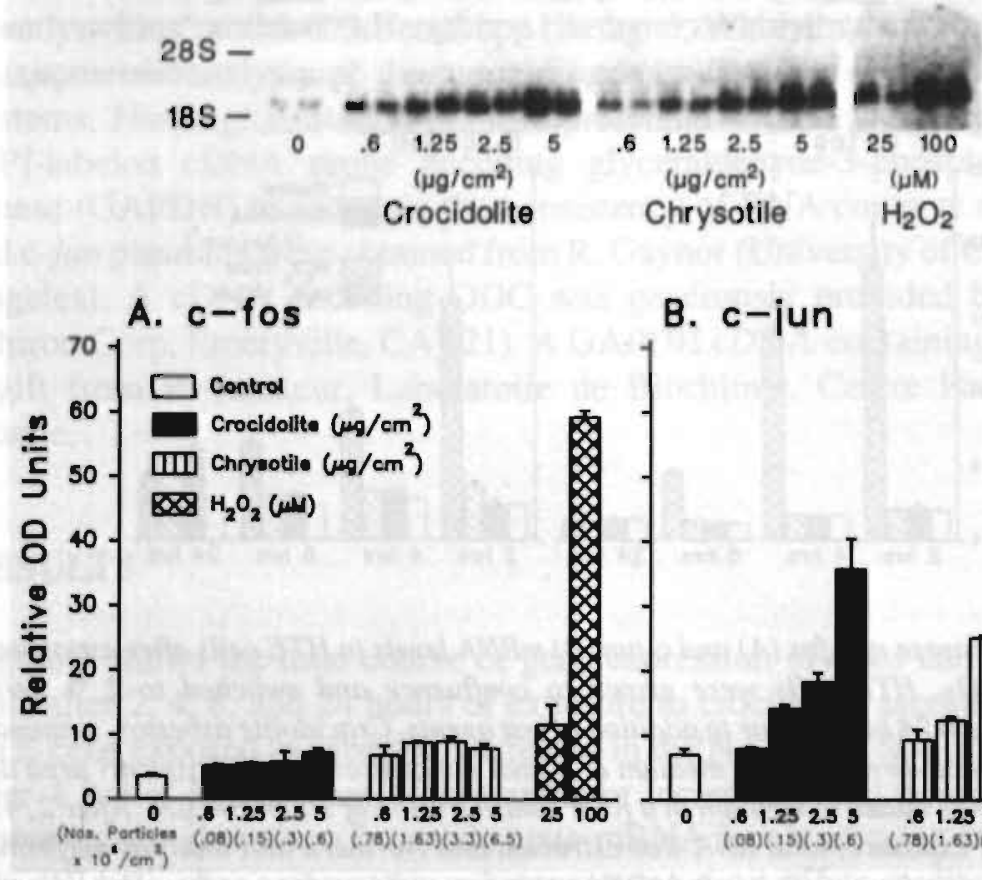

B. c-jun

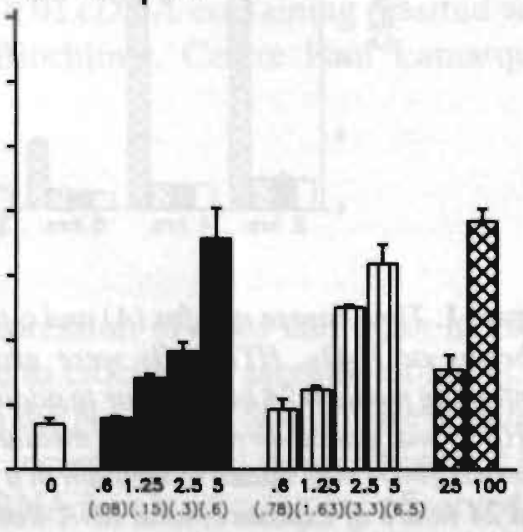

Figure 2. Dose response studies measuring steady state levels of $c$-fos $(A)$ and $c$-jun $(B)$ mRNA levels in HTE cells after 8 hours of exposure to ashestos or $\mathrm{H}_{2} \mathrm{O}_{2}$. Cells at confluence were exposed to increasing amounts of crocidolite or chrysotile asbestos or $\mathrm{H}_{2} \mathrm{O}_{2}$, and after 8 hours of exposure RNA was extracted and used in Northern blot analysis. Results were quantitated by densitometry and expressed in relative $O D$ units (mean + S.E.M.). Results are

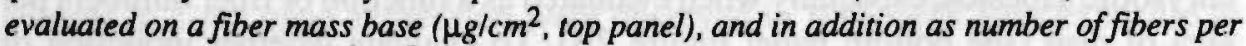
dish (Nos. Particles $\times 10^{6} / \mathrm{cm}^{2}$, bottom panel).

exposure of HTE cells to riebeckite, a non-fibrous analog chemically identical to crocidolite asbestos, did not alter c-jun mRNA levels. These data suggest that c-jun induction in HTE cells is related to fibrous geometry and most pronounced with crocidolite asbestos fibers. 

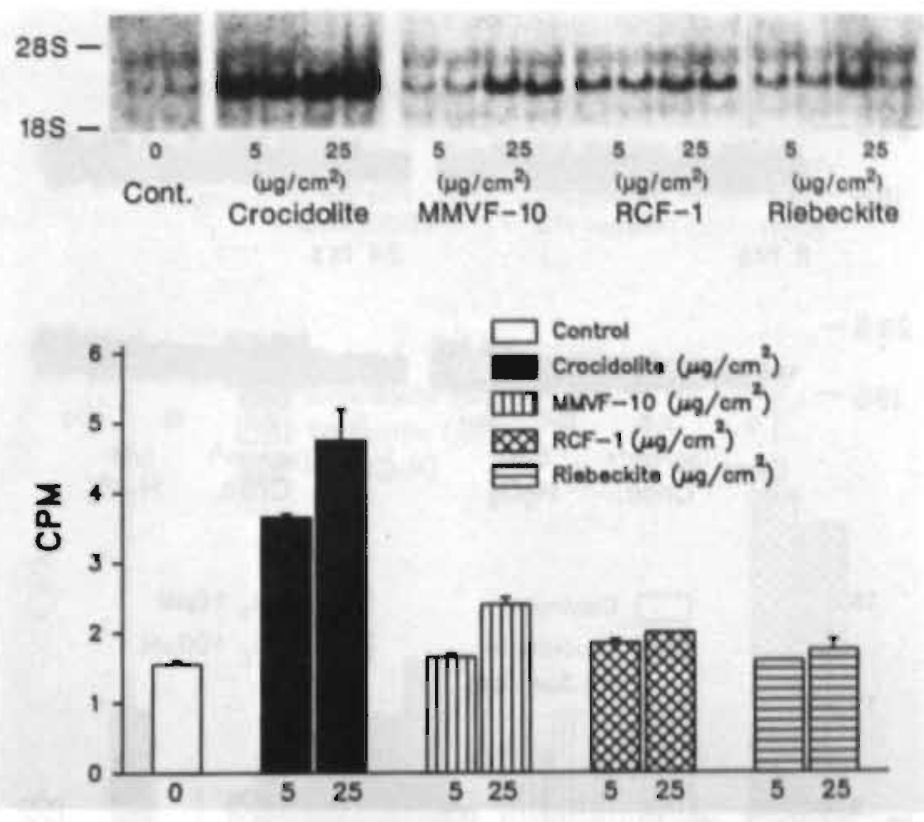

Figure 3. Examination of $c$-jun mRNA levels in HTE cells after 24 hours of exposure to different mineral dusts at concentrations of 5 or $25 \mu \mathrm{g} / \mathrm{cm}^{2}$ area dish. HTE cells were exposed to crocidolite asbestos, and in addition to the man made vitreous fibers, MMVF-IO or RCF-1. In addition, riebeckite was evaluated as a non-fibrous particulate analog, chemically identical to crocidolite asbestos. Results are expressed in cpm (mean + S.E.M.).

To determine whether proliferative events occurred in HTE cells following exposure to mineral dusts, we examined mRNA levels of ODC. Figure 4 shows a time course of ODC mRNA expression in HTE cells after exposure to 2.5 $\mu \mathrm{g} / \mathrm{cm}^{2}$ of crocidolite asbestos or 10 and $100 \mu \mathrm{M}$ of $\mathrm{H}_{2} \mathrm{O}_{2}$. After 8 hours of exposure to $2.5 \mu \mathrm{g} / \mathrm{cm}^{2}$ crocidolite asbestos, increases in ODC mRNA levels were observed in HTE cells. Increases were approximately 3 fold compared to controls after 24 hours of exposure. Exposure of HTE cells to $\mathrm{H}_{2} \mathrm{O}_{2}$ for 8 or 24 hours also resulted in increases in mRNA levels of ODC (Figures 4 and 5). Results indicate that increases in c-jun mRNA levels parallel asbestos-induced increases in ODC mRNA. However, increases in c-jun gene expression preceded increases in mRNA levels of ODC after exposure of HTE cells to $\mathrm{H}_{2} \mathrm{O}_{2}$.

Induction of ODC by asbestos in HTE cells is dose dependent and observed after exposure to both types af asbestos (Figure 5). Striking increases in ODC mRNA levels were observed in cells treated with higher concentrations ( 5 and 25 
2 hrs

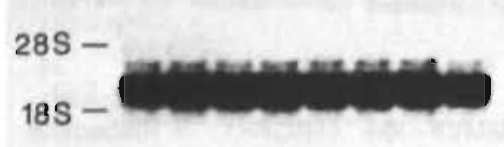

$8 \mathrm{hrs}$
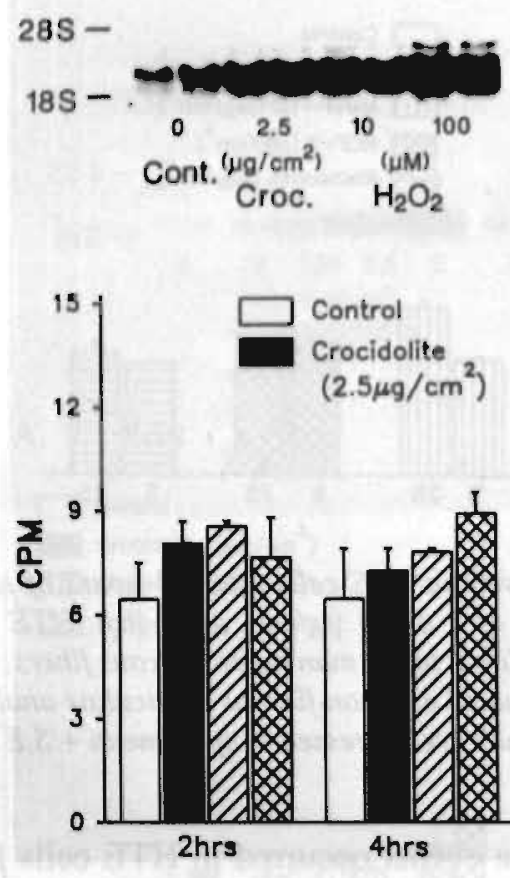

4. hrs

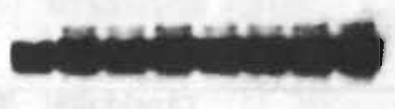

$24 \mathrm{hrs}$

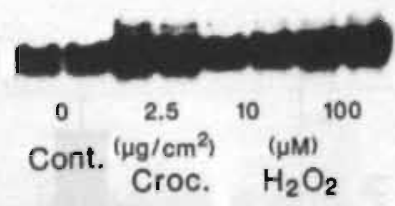

$\mathrm{H}_{2} \mathrm{O}_{2} \quad 100 \mu \mathrm{M}$

$\mathrm{H}_{2} \mathrm{O}_{2} 100 \mu \mathrm{M}$ . 

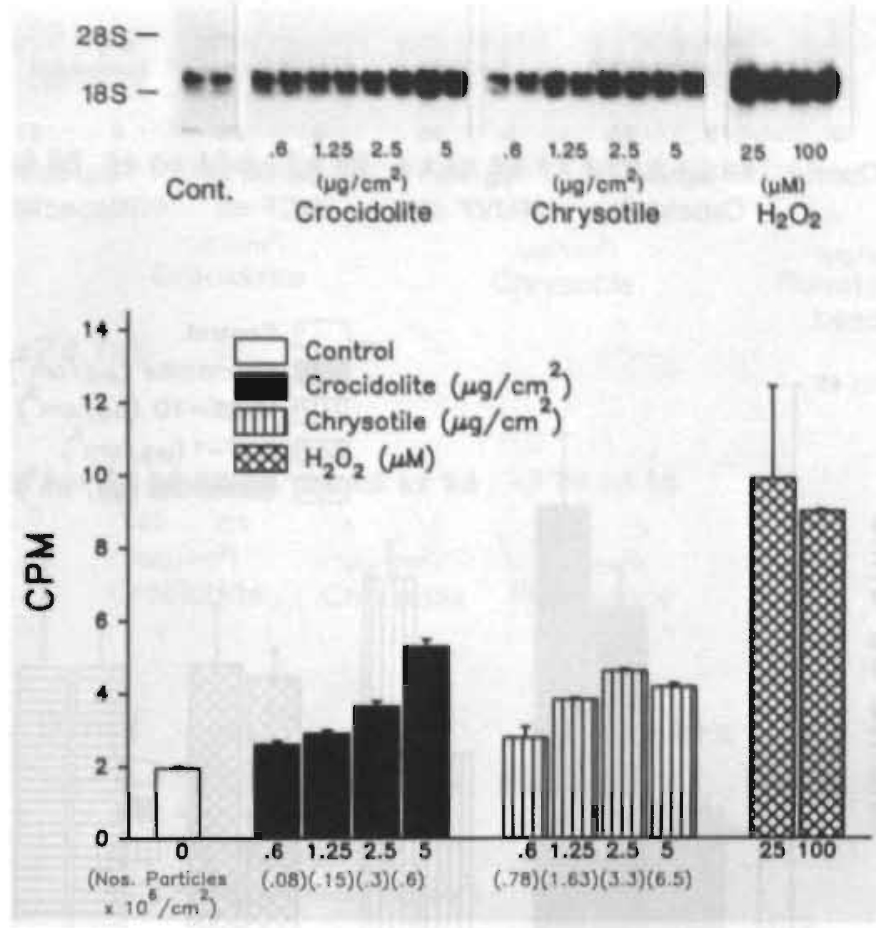

Figure 5. Dose response study examining mRNA levels of $O D C$ in HTE cells after 8 hours of exposure to increasing amounts of crocidolite asbestos, chrysotile asbestos, or $\mathrm{H}_{2} \mathrm{O}_{2}$. Results are expressed in cpm (mean + S.E.M.).

exposure to crocidolite, chrysotile, or polystyrene beads for 8 hours. Only modest increases were detectable in RPM cells at highest concentrations of asbestos used. After 24 hours of exposure of RPM cells to asbestos, ODC mRNA levels were increased in RPM cells exposed to crocidolite asbestos, but not after exposure to chrysotile asbestos or polystyrene beads (Figure 7B). The magnitude of increases in ODC mRNA levels following exposure to asbestos were less pronounced in RPM cells in comparison to HTE cells.

We next evaluated whether exposure to a number of different particulates caused increases in c-fos and c-jun mRNA in RPM cells. Figure 8 shows mRNA expression of c-fos and c-jun in RPM cells after 8 hours of exposure to crocidolite asbestos, MMVF-10, RCF-1 or riebeckite. Striking increase in c-fos and c-jun mRNA levels were observed in RPM exposed to $2.5 \mu \mathrm{g} / \mathrm{cm}^{2}$ of crocidolite asbestos. However, addition of MMVF-10, RCF-1 fibers or the particle, riebeckite, did not alter steady state mRNA levels of protooncogenes. A subsequent study examining higher concentrations of these fibers (5-25 $\mu \mathrm{g} / \mathrm{cm}^{2}$ ) revealed increases in c-fos and c-jun mRNA levels after exposure to 

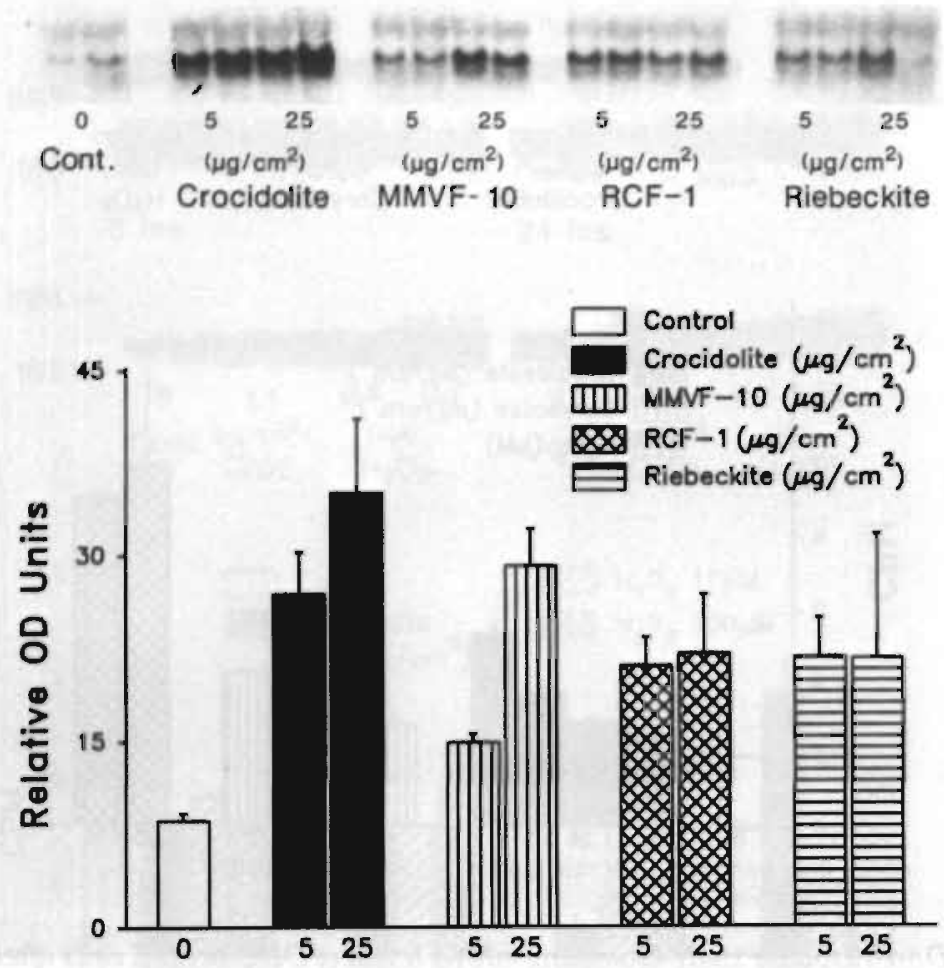

Figure 6. $M R N A$ levels of $O D C$ in HTE cells after 24 hours of exposure to different fibers or particulates. HTE cells were exposed to crocidolite asbestos, MMVF-10, RCF-1, or riebeckite at concentrations of 5 or $25 \mu \mathrm{g} / \mathrm{cm}^{2}$ of dusts for 24 hours. RNA was harvested for Northern blot analysis. Results are expressed in relative $O D$ units (mean + S.E.M.).

MMVF-10 or RCF-1 at $25 \mu \mathrm{g} / \mathrm{cm}^{2}$ (Figure 9). Erionite, a naturally occurring fiber associated with the development of mesothelioma in man (22) induced c-fos and c-jun mRNA levels at extremely low concentrations $\left(0.1-5 \mu \mathrm{g} / \mathrm{cm}^{2}\right)$ of fibers tested (Figure 9). However, a dose dependent increase in protooncogene expression was not observed using crocidolite at these high concentrations (10 and $25 \mu \mathrm{g} / \mathrm{cm}^{2}$ ). 


\section{A. $8 \mathrm{hrs}$}

$28 \mathrm{~S}-$

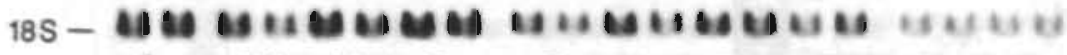

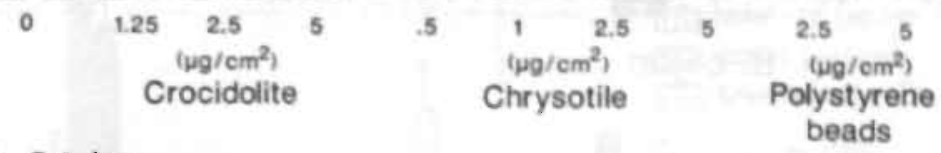

B. $24 \mathrm{hrs}$

$28 \mathrm{~S}-$

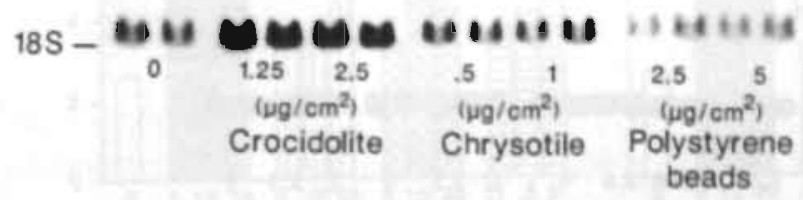

A. 8 hrs

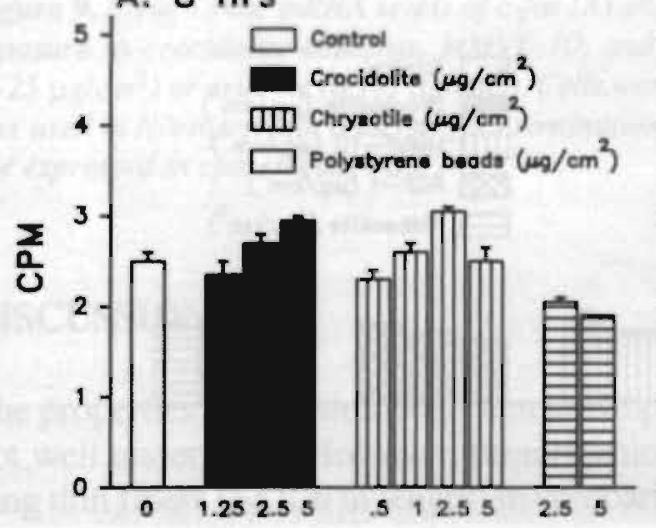

B. $24 \mathrm{hrs}$

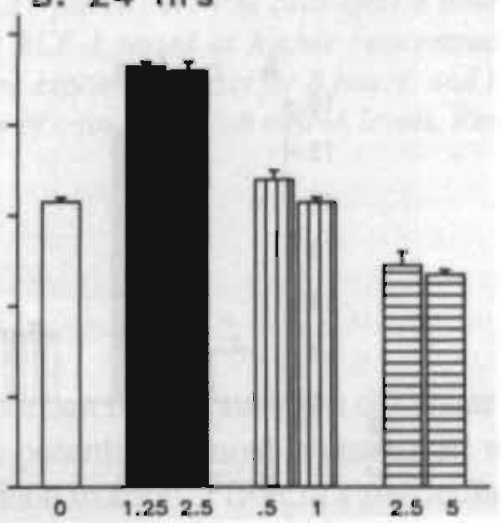

Figure 7. Steady state levels of ODC mRNA in RPM cells after exposure to ashestos or polystyrene beads. RPM cells were exposed to increasing concentrations of crocidolite asbestos, chrysotile asbestos or polystyrene beads for $8(A)$ or 24 hours (B). RNA was isolated and Northern blot analyses performed. Results are expressed in cpm (mean + S.E.M.). 
A. c-fos

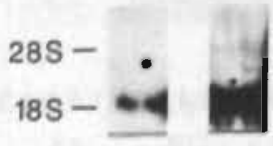

B. c-jun

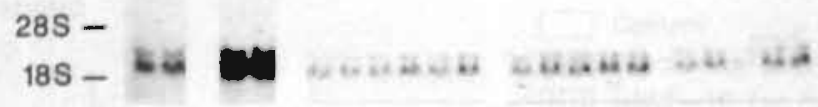

\section{GAPDH}
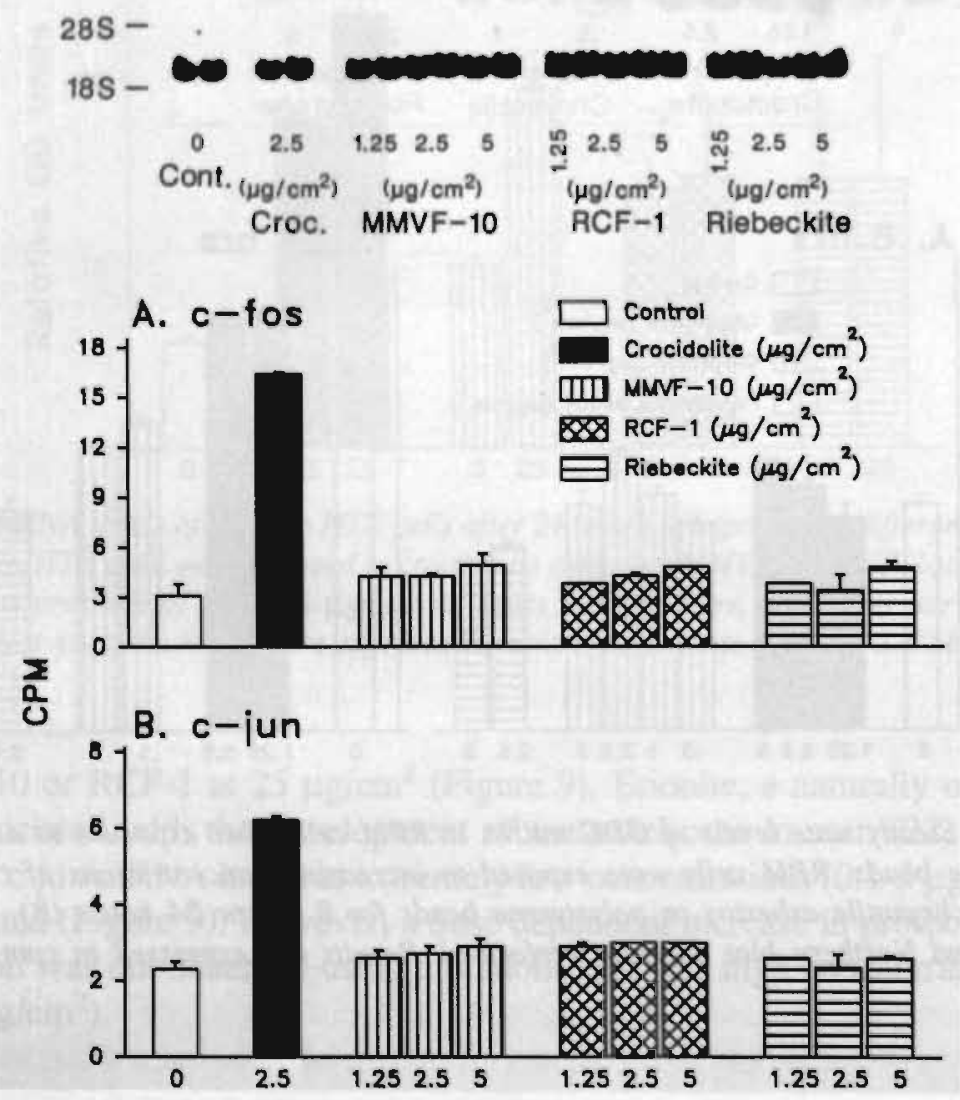

Figure 8. Steady state mRNA levels of $c$-fos $(A)$ and $c$-jun (B) in RPM cells after 8 hours of exposure to different fibers or particulates. RPM cells at confluence were exposed to crocidolite asbestos at $2.5 \mu \mathrm{g} / \mathrm{cm}^{2}$, or to MMVF-10,RCF-1 or riebeckite at $1.25,2.5$, or 5 $\mu \mathrm{g} / \mathrm{cm}^{2}$. After 8 hours of exposure, RNA was isolated for Northern blot analysis. Results are expressed in cpm (mean + S.E.M.). GAPDH mRNA levels are shown to confirm equal RNA contents. 

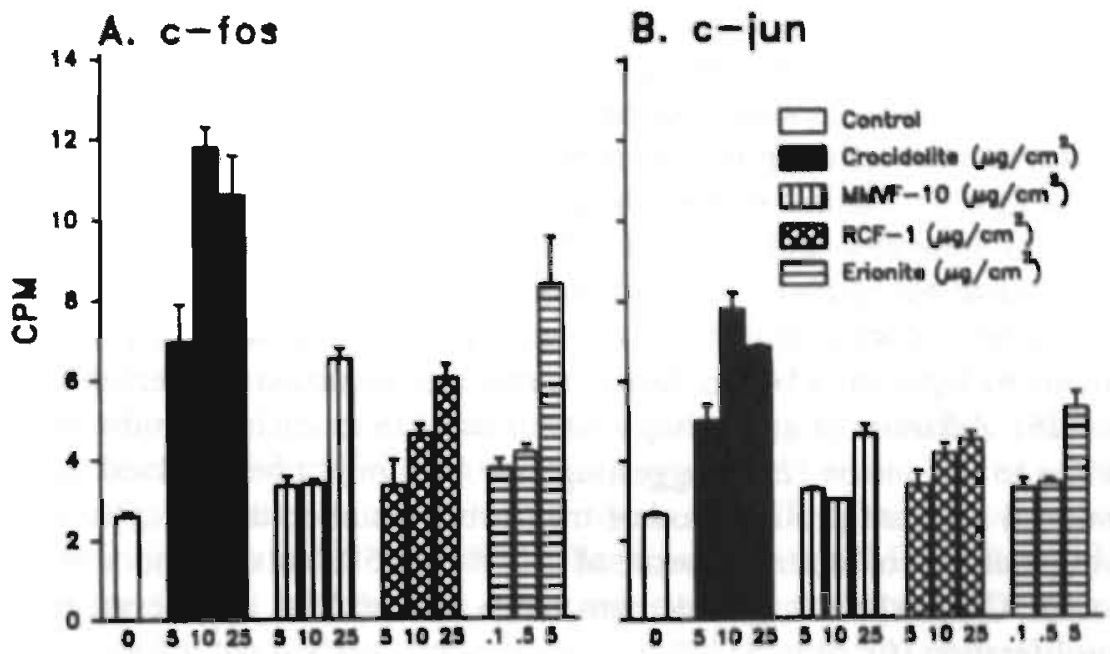

Figure 9. Steady state mRNA levels of $c$-fos (A) and c-jun (B) in RPM cells after 8 hours of exposure to crocidolite asbestos, MMVF-10, and RCF-1 tested at higher concentrations $\left(5-25 \mu \mathrm{g} / \mathrm{cm}^{2}\right)$ or erionite $\left(0.1-5 \mu \mathrm{g} / \mathrm{cm}^{2}\right)$. Cells were exposed to dusts for 8 hours, and RNA was used in Northern blot analysis for examination of c-fos and c-jun mRNA levels. Results are expressed in cpm (mean + S.E.M.).

\section{DISCUSSION}

The properties of asbestos fibers that are important in the causation of cancer are not well understood. However, tumorigenic potential is most pronounced with long thin fibers ( $>5 \mu \mathrm{m}$ in length) in comparison to shorter fibers or particulates, indicating that fiber size and geometry are critical in fiber carcinogenicity. In addition, fiber durability and persistence in the lung and pleura may be important in tumor development (1). For example, amphibole asbestos fibers which give rise to mesothelioma in man display longer persistence in human lungs in comparison to chrysotile, which is rarely associated with mesothelioma (23). Whereas asbestos is a complete carcinogen in the development of mesothelioma, asbestos appears to act primarily as a tumor promoter or cocarcinogen in the development of bronchogenic carcinoma, perhaps by facilitating the uptake, metabolism and/or DNA binding of chemical carcinogens (24).

Studies by our laboratory and others have suggested that active oxygen species (AOS) are important mediators of asbestos-induced disease. AOS are generated by inflammatory cells such as macrophages and polymorphonuclear leukocytes during attempted phagocytosis of long asbestos fibers (16). Altematively AOS 
are formed by redox reactions occurring on the fibers, in absence of cells $(25,26)$. Evidence for a role of AOS in asbestos-induced lung disease stems from a number of studies demonstrating that cytotoxicity caused by asbestos exposure in different target cells can be prevented by simultaneous exposure of cells to antioxidants (27). Studies in our laboratory have demonstrated that acute lung damage, inflammation and pulmonary fibrosis can be ameliorated in rats inhaling crocidolite by systemic adminstration of the antioxidant enzyme catalase (10). Exposure of organ cultures of tracheal epithelium to asbestos gives rise to squamous metaplasia, a benign lesion sometimes regarded as premalignant in nature (28). Addition of generating systems of AOS to tracheal epithelium also gives rise to this lesion (29), suggesting that AOS might be involved in asbestos-induced aberrant proliferation of tracheobronchial epithelial cells. Studies showing that concomittant exposure of cells to antioxidants ameliorates induction of ODC by asbestos, also demonstrate a role of AOS in asbestos-induced cell proliferation (6).

In the present study, we examined induction of c-fos and c-jun protooncogenes by asbestos in different target cells of asbestos-induced disease. Since AOS appear to mediate certain proliferative events triggered by asbestos, we determined comparatively whether the AOS, $\mathrm{H}_{2} \mathrm{O}_{2}$ elevated c-fos and c-jun protooncogene expression in the same fashion. Our results show that exposure of HTE cells to $\mathrm{H}_{2} \mathrm{O}_{2}$ for 2 hours causes a dramatic induction of c-fos and c-jun protooncogenes which decreased to control levels at 24 hours. Interestingly, no mRNA levels of c-fos were observed in HTE cells after exposure to asbestos indicating that AOS production by asbestos may be insufficient to induce c-fos in these cells. Alternatively, other members of the fos/jun gene family might be induced in $\mathrm{HTE}$ cells both asbestos and $\mathrm{H}_{2} \mathrm{O}_{2}$. Recent experiments also indicate that c-fos and c-jun are not induced in RPM cells after addition of $\mathrm{H}_{2} \mathrm{O}_{2}$ or generating systems of AOS. Yet, under these conditions, gene expression of manganese containing superoxide dismutase and heme oxygenase (enzymes induced by oxidants) is elevated, indicative of an oxidant stress response (Janssen et al., in preparation). These results indicate that the pathways of c-fos and c-jun activation triggered by asbestos and AOS in the HTE or RPM cells are different.

Steady state mRNA levels of ODC are increased in HTE cells after exposure to asbestos or $\mathrm{H}_{2} \mathrm{O}_{2}$, indicating that proliferative events occur after exposure to these agents (Figure 4). Since asbestos and $\mathrm{H}_{2} \mathrm{O}_{2}$ cause different patterns of c-fos and c-jun gene expression in HTE cells, these results suggest that different molecular pathways of cell proliferation may be activated by various oxidative stresses. 
An interesting finding of the results presented here is that fibrous dusis with differing carcinogenic potentials lead to a different magnitude in c-fos and c-jun protooncogene induction. As demonstrated previously, when evaluated on a fiber number basis, crocidolite is more potent in increasing c-fos and c-jun gene expression in RPM cells, in comparison to chrysotile asbestos (12). In the present study, we demonstrated the same effect on c-jun mRNA levels in HTE cells (Figure 2). Exposure of HTE or RPM cells to non-fibrous particulates did not alter mRNA levels of c-fos and c-jun (12) (Figures 3 and 8). These results suggest that the fibrous nature of asbestos appears to be important in induction of protooncogenes. Examination of other fiber types, including man made vitreous fiber-10 (MMVF-10) and refractory ceramic fiber (RCF-1), showed less striking increases in c-jun mRNA levels in HTE cells, in comparison to asbestos (Figure 3). In RPM cells, similar results with MMVF-10 and RCF-1 fibers were found. Increases in c-fos and c-jun gene expression were only demonstrated at the highest concentrations tested (Figure 9).

Epidemiological studies investigating occupational exposure to man made mineral fibers and the development of pulmonary neoplasms showed limited evidence of an increased incidence of tumor development $(13,30)$. Two recent studies evaluating the carcinogenic potential of MMVF and RCF fibers in rodents showed no increases in lung tumors or mesotheliomas after inhalation of MMVF-10 fibers $(31,32)$. In contrast, pulmonary tumors and mesotheliomas were observed in rats following inhalation of RCF. Thus, ceramic fibers appear to be more pathogenic than other man made mineral fibers examined so far in rodent inhalation models, presumably due to their increased durability in the lung or pleura. However, intrapleural or intratracheal injection techniques have demonstrated the development of tumors following administration of either fiber, indicating that both MMVF-10 and RCF-1 (as well as a number of other fiber types) have the capacity to cause tumors if present at the target site in sufficient concentrations $(13,30)$. In the present study we demonstrated that MMVF-10 fibers and RCF-1 fibers elevate c-fos and c-jun protooncogene expression in two target cells of asbestos-induced disease i.e. the pleural mesothelial cell and the tracheal epithelial cell. However, in comparison to asbestos, protooncogene induction is less pronounced after exposure to MMVF10 or RCF-1 fibers. Increases in mRNA levels of ODC that occur concomittantly suggest that proliferative effects occur in HTE cells treated with MMVF-10 or RCF-1 fibers. Our studies suggest that induction of the fos/jun gene family by these fibers might be involved in chronic cell proliferation.

Erionite, a fiber extremely potent in inducing mesothelioma in man (22) and rodents (33), caused more striking increases in mRNA expression of $c$-fos and c-jun in RPM cells, when compared to crocidolite asbestos (Figure 9). Thus, 
examination of activation of the early response gene pathway in target cells of tumor development after exposure to asbestiform fibers might aid in identifying potential harmful dusts.

\section{Acknowledgements}

The authors thank Judith Kessler for providing the illustrations and Ping Taishi for technical assistance. This work was supported by grants from the National Institutes of Health (R01HL39469) and the Environmental Protection Agency. 


\section{REFERENCES}

1 Mossman, B.T., Bignon, J., Com, M., Seaton, A., and Gee, J.B.L. Asbestos: scientific developments and implications for public policy. Science, 247: 294-301, 1990.

2 Mossman, B.T., Marsh, J.P. Role of active oxygen species in asbestos-induced cytotoxicity, cell proliferation and carcinogenesis. In: Harris, C.C., Lechner, J.F., Brinkley, B.R.(Eds.), Cellular and Molecular Aspects of Fiber Carcinogenesis, pp. 159-168. Cold Spring Harbor, Cold Spring Harbor Laboratory Press, 1991.

3 O'Brien, T.G., The induction of omithine decarboxylase as an early, possibly obligatory, event in mouse skin carcinogenesis. Cancer. Res., 36: 2644-2653, 1976.

4 Sesko, A., Cabot, M., Mossman, B. Hydrolysis of inositol phospholipids precedes cellular proliferation in asbestos-stimulated tracheobronchial epithelial cells. Proc. Natl. Acad. Sci. U.S.A. 87: 7385-7389, 1990.

5 Perderiset, M., Marsh, J.P., Mossman, B.T. Activetion of protein kinase C by crocidolite asbestos in hamster tracheal epithelial cells. Carcinogenesis, 12: 1499-1502, 1991.

6 Marsh, J.P., Mossman, B.T. Role of asbestos and active oxygen species in activation and expression of omithine decarboxylase in hamster tracheal epithelial cells. Cancer Res., 51: 167-173, 1991.

7 Pegg, A.E., Polyamine metabolism and its importance in neoplastic growth and as a target for chemotherapy. Cancer Res., 48: 759-774, 1988.

8 Gilmour, S.K., Verma, A.K., Madara, T., O'Brien, T.G. Regulation of omithine decarboxylase gene expression in mouse epidermis and epidermal tumors during two-stage carcinogenesis. Cancer Res., 47: 1221-1225, 1987.

9 Marsh, J.P., Mossman, B.T. Mechanisms of induction of ornithine decarboxylase activity in tracheal epithelial cells by asbestiform minerals. Cancer Res., 48: 709-714, 1988.

10 Mossman, B.T., Marsh, J.P., Sesko, A., Hill, S., Shatos, M.A., Doherty, J., Petruska, J., Adler, K.B., Hemenway, D., Mickey, R., Vacek,P., Kagan, E. Inhibition of lung injury, inflammation and interstitial pulmonary fibrosis by polyethylene glycol-conjugated catalase in a rapid inhalation model of asbestosis. Am. Rev. Respir. Dis., 141: 1266$1271,1990$.

11 Angel, P., Karin, M. The role of Jun, Fos and the AP-1 complex in cell-proliferation and transformation. Biochim. Biophys. Acta., 1072: 129-157, 1991.

12 Heintz, N.H., Janssen, Y.M.W., Mossman, B.T. Persistent induction of c-fos and c-jun protooncogene expression by asbestos. Proc. Natl. Acad. Sci. U.S.A., (in Press).

13 Mossman, B.T., Gee, J.B.L. Pulmonary reactions and mechanisms of tocixity of inhaled fibers. In: D.E. Gardner et al. (eds.), Toxicology of the Lung, 2nd ed., pp.371-387. New York: Raven Press, 1993.

14 Petruska, J.M., Mossman, B.T., Brown, R.C., Hoskins, J.A. Mechanisms of action of mineral fibers as studied by in vitro methods. In: Liddell, D., Miller, K. (eds.), Mineral Fibers and Health, pp.303-319, Boca Raton: CRC Press, 1991.

15 Mossman, B.T., Sesko, A.M. In vitro assays to predict the pathogenicity of mineral fibers. Toxicology, 60: 53-61, 1990.

16 Hansen, K., Mossman, B.T. Generation of superoxide $\left(\mathrm{O}_{2}-\right)$ from alveolar macrophages exposed to asbestiform and non-fibrous particles. Cancer Res., 47: 1681-1686, 1987. 
17 Mossman, B.T., Ezerman, E.B., Adler, K.B., Craighead, J.E. Isolation and spontaneous transformation of cloned lines of hamster tracheal epithelial cells. Cancer Res., 40: 4403-4409, 1980.

18 Jaurand, M.C., Renier, A., Meeren, van der A., Magne, J., Pinchon, L., Bignon, J. Rat pleural mesothelial cells in culture. In Vitro., 17: 98-108, 1981.

19 Chomzcynski, P., Sacchi, N. Signle step method of RNA isolation by acid guanidinium thiocyanate-phenol-chloroform extraction. Anal. Biocem., 162: 156-159, 1987.

20 Sambrook, J., Fritsch, E.F., Maniatis, T. Molecular Cloning: A laboratory Manual. Cold Spring Harbor, NY; Cold Spring Harbor Labaratory Press, 1989.

21 McConlogue, L., Gupta, M., Wu, L., Coffino, P. molecular clonong and expression of the mouse omithine decarboxylase gene. Proc. Natl. Acad. Sci. U.S.A. 81: 540-544, 1984.

22 Artvinli, M., Baris. Y.I. Malignant mesothelioma in a small village in the Anatolian region in Turkey: an epiderniological study. J. Natl. Cancer. Inst., 63: 17-22, 1979.

23 Churg, A. Analysis of lung asbestos content. Br.J.Ind.Med., 48: 649-652, 1991.

24 Mossman, B.T. Carcinogenic potential of asbestos and non-asbestos fibers. Envir. Carcino. Revs., (J. Envir. Sci. Hith.), 6: 151-195, 1988.

25 Weitzman, S.A., Gracelfa, P. Asbestos catalyzes hydroxyl and superoxide radical generation fron hydrogen peroxide. Arch. Biochem. Biophys., 228: 373-7, 1984.

26 Zalma, R., Bonneau, L., Jaurand, M.C., Guignard, J., Pezarat, H. Formation of oxy-radicals by oxygen reduction arising from the surface activity of asbestos. Can. J. Chem., 65:2338-2341, 1988.

27 Shatos, M.A., Doherty, M.A., Marsh, J.P., Mossman, B.T. Prevention of asbestos-induced cell death in rat lung fibroblasts and alveolar macrophages by scavengers of active oxygen species. Environ. Res., 44: 103-116, 1987.

28 Cameron, G., Woodworth, C.D., Edmondson, S., Mossman, B.T. Mechanisms of asbestos-induced squamous metaplasia in tracheobronchial epithelial cells. Environ. Health, Perspect., 80: 101-108, 1989.

29 Radosevich, C.A., Weitzman, S.A. Hydrogen peroxide induces squamous metaplasia in a hamster tracheal organ explant culture model. Carcinogenesis. 10: 1943-1946, 1989.

30 Asbestos in Public and Commercial Buildings: A Literature Review and Synthesis of Current Knowledge. Health Effects Institute-Asbestos Research, Cambridge MA, 1991.

31 Hesterberg, T.W., Miiller, W.C., McDonnell, E.E., Chevalier, J., Hadley, J.G., Bernstein, D.M., Thevenaz, P., Anderson, R. Chronic inhalation toxicity of sizeseparated glass fibers in Fischer 344 rats. Fund Appl Toxicol 1993 (in Press).

32 Bunn, W.N., Bender, J.R., Hesterberg, T.W., Chase, G.R., Konzen, J.L. Recent studies of man-made vitreous fibers:chronic animal inhalation studies. J. Occup. Med. (In press).

33 Wagner, J., Skidmore, J.W., Hill, R.J., Griffiths, D.M. Erionite exposure and malignant mesothelioma in rats. Br.J. Cancer., 51: 727-730, 1985.

34 Woodworth, C.D., Mossman, B.T., Craighead, J.E. Induction of squamous metaplasia in organ cultures of hamster tracheal epithelial cells by naturally occurring and synthetic fibers. Cancer Res., 43: 4906-4912, 1983. 


\section{Summary and General Discussion}

Responses of cells and tissues to a number of different oxidant stresses are complex. Some genes which are induced are unique to the type of oxidant stress which is applied, whereas other responses appear to be more general. Alterations in components of the antioxidant system, including increases in gene expression and/or protein levels of manganese-containing superoxide dismutase (MnSOD) are common responses. However, other stress responses are related to cellular differentiation status and growth behavior of cells. Certain gene products appear to be involved in growth arrest whereas others are indicative of increased proliferation (chapter 2). In this thesis, molecular stress responses were studied in rodent lung or isolated target cells following exposure to selected mineral dusts. Since active oxygen species (AOS) are important mediators of mineral dust-induced lung disease, molecular responses to mineral exposure may be comparable to other oxidant stresses. The studies described in this thesis reveal alterations in antioxidant defenses, dependent on the type of mineral used. However, other responses observed in rodent lung or different target cells after exposure to AOS or mineral dusts were related to increases in proliferation (chapters 2 and 3).

Inhalation of mineral dusts can lead to development of a number of different lung diseases, including fibrosis, bronchogenic carcinoma or mesothelioma (1). Numerous studies have indicated that AOS have an important role in the etiology of these diseases (2). In this thesis, the effects of mineral dusts on the antioxidant enzyme (AOE) system were studied in whole rat lung as well as pulmonary target cells of asbestos-induced disease in vitro. In rat lung, inhalation of $7-10 \mathrm{mg} / \mathrm{m}^{3}$ of crocidolite asbestos caused increases in gene expression of $\mathrm{AOE}$ and overall increased $\mathrm{AOE}$ activities. In contrast, inhalation of cristobalite silica, at equal airborne mass concentrations, caused dramatic increases in mRNA expression and protein levels of MnSOD. Gene expression of other AOE remained mostly unaltered and no increases in activities of AOE were observed following cristobalite inhalation. Thus profiles of AOE appeared to be dissimilar in rat lung during the development of asbestosis or silicosis (chapter 4). A subchronic study using 10-fold lower airbome concentrations of cristobalite silica or two different preparations of titanium dioxide $\left(\mathrm{TiO}_{2}\right)$ substan- 
tiated previous findings and revealed dramatic increases in gene expression and protein levels of MnSOD in lung or cells obtained from bronchoalveolar lavage, after inhalation of cristobalite. Ultrafine $\mathrm{TiO}_{2}$-Degussa, which caused dramatic inflammation, pulmonary damage and fibrosis also caused increases in gene expression and protein levels of $\mathrm{MnSOD}$, similar to cristobalite. $\mathrm{TiO}_{2}$-Fisher, a larger particle which did not give rise to inflammation or fibrosis failed to alter mRNA or protein levels of MnSOD (chapter 5). These studies indicate that measurement of mRNA or protein levels of MnSOD in lung is a sensitive marker for inflammation caused by exposure to mineral dusts giving rise to pulmonary fibrosis.

Increases in gene expression of $\mathrm{AOE}$ observed in rat lung following inhalation of mineral dusts, including asbestos and silica can be regarded as a response to mineral dust-induced oxidative stress which could lead to adaptation to subsequent oxidant insults. However at the high airbome concentrations of mineral dusts applied in our inhalation models $\left(7-10 \mathrm{mg} / \mathrm{m}^{3}\right)$, antioxidant defenses might be overwhelmed and cell and tissue damage ensue. In this respect, gene expression of CuZnSOD, catalase and GPX was never elevated more than twofold, and enzymatic activities of $\mathrm{AOE}$ following asbestos inhalation showed similar increases. Moreover, inhalation of cristobalite or $\mathrm{TiO}_{2}$ did not result in increases of $\mathrm{AOE}$ activities in whole rat lung. These results suggest that increases in $\mathrm{AOE}$ might be insufficient to protect the lung from mineral dust induced oxidative damage. Alternatively, local increases in AOE defenses can occur in rat lung which might not be measurable employing homogenates of lung. In support of this, increases in immunoreactive protein of MnSOD occur in type II pneumocytes of rat lungs, following inhalation of crocidolite asbestos or cristobalite, whereas other cell types of the lung only display minor labeling of MnSOD, or no labeling at all (3).

Exposure of human pleural mesothelial cells to asbestos or generating systems of AOS (xanthine plus xanthine oxidase, $\mathrm{X} / \mathrm{XO}$ ) in vitro, resulted in increases in gene expression of MnSOD. Moreover mRNA levels of heme oxygenase (HO), an enzyme sensitive to oxidative stress, were also induced in these cells following exposure to asbestos or $\mathrm{X} / \mathrm{XO}$. Examination of human adult lung fibroblasts, a cell type less sensitive to the cytotoxic effects of asbestos or $\mathrm{X} / \mathrm{XO}$, showed less striking increases in gene expression of $\mathrm{MnSOD}$ or $\mathrm{HO}$ in response to these agents. These results indicate that oxidative stress responses occur in human pleural mesothelial cells following exposure to asbestos or AOS in vitro. Although human mesothelial cells are exquisitely sensitive to asbestos or AOS, they are not compromised in their ability to respond defensively to oxidative stress (chapter 6).

As described above, rodent lungs or human pulmonary target cells respond to high concentrations of asbestos with increases in antioxidant defenses. How- 
ever, the extent and localization of these responses might not be adequate to protect the lung and pulmonary disease arises. During the development of mineral dust-induced pulmonary disease, a number of proliferative alterations are observed in different cell types of the lung. For example, mRNA levels of ornithine decarboxylase (ODC), an enzyme intrinsic to cell proliferation, were increased in rat lung following inhalation of asbestos or silica (chapter 3). Furthermore, gene expression and enzymatic activity of ODC were increased in HTE cells after exposure to asbestos in vitro (4). Evidence for the involvement of AOS was obtained by administration of antioxidants which ameliorated these increases (5). Since molecular events involved in mineral dust-induced proliferation are not well understood, mRNA levels of c-fos, c-jun, or ODC were determined in tracheal epithelial (HTE) or pleural mesothelial cells (RPM) following exposure to asbestiform minerals. Asbestos caused dramatic increases in mRNA levels of $c-f o s$ and $c-j u n$ that persisted for at least 24 hours in rat pleural mesothelial cells. Induction of c-jun gene expression by asbestos also occurred in tracheal epithelial cells, but was not accompanied by a corresponding increase in c-fos gene expression. In both cell types, asbestos induced increases in protein factors which bind specifically to DNA containing AP-1 sites (chapter 7). The induction of $c-j u n$ and/or c-fos gene expression was dose dependent and most pronounced with crocidolite asbestos, the most pathogenic in the causation of pleural mesothelioma (chapters 7 and 8). In comparison to asbestos, other mineral fibers, including man made vitrous fibers or refractory ceramic fibers caused less striking increases in expression of these genes at the highest concentrations that were studied (chapter 8). Moreover, the fibrous nature of asbestos was critical in protooncogene induction since riebeckite, a non-fibrous particulate analog chemically identical to crocidolite asbestos, or polystyrene beads did not induce gene expression of c-fos or c-jun. Exposure of tracheobronchial epithelial cells or mesothelial cells to AOS directly revealed patterns of induction of c-fos and c-jun which differed from the asbestos-induced expression of these genes. These results indicate that the pathways activated after asbestos or AOS exposure leading to induction of these early immediate genes are distinct. In HTE cells, increases in c-jun mRNA paralleled increases in gene expression of ODC after asbestos exposure. This indicates that induction of the immediate early gene pathway by asbestos is accompanied by changes in expression of another gene essential in cell proliferation (chapter 8). Persistent activation of AP-1 transcription factors by asbestos fibers may be involved in chronic stimulation of cell proliferation. These studies suggest that asbestos may act as a mitogen in carcinogenesis or in induction of fibrosis by persistently activating the early response gene pathway.

The long protraction period of mineral dust-induced lung damage in man necessitates development of test systems which enable investigators to assess toxic risks and health effects associated with exposure to mineral dusts (6). A 
number of different systems have been used in the risk assessment of mineral dusts. These include; rodent inhalation studies, intrapleural and intraperitoneal injection techniques, organ cultures, and in vitro culture systems employing homogeneous cell populations $(7,8)$. All of these techniques have advantages and limitations. For instance, one pitfall of rodent inhalation studies is the limited life span of the animal which can lead to false negative results when assessing risks for development of tumors, which in rodents normally appear around the end of the life span after inhalation of mineral dusts. In several cases, minerals known to produce tumors in man were negative in these studies. Thus, alternatives to inhalation studies emerged i.e. intrapleural or intraperitoneal injection techniques, to deliver mineral dusts directly to the target site; mesothelial cells. In these systems every mineral with the right size dimensions that was injected produced tumors, even those minerals not associated with mesothelioma in man. These false positive test results are the result of lack of consideration of mineral durability and pulmonary clearance mechanisms. However, these studies provide important information on the potential of a mineral to elicit disease once reached the target site (9). Usage of homogeneous cell populations to determine responses of mineral have important advantages because they enable studies of molecular alterations within cells and the relationhip to a number of endpoints; toxicity, increases defenses, or increased/aberrant proliferation. Thus the early events trigerred within the cell that precede disease, including fibrosis, bronchogenic carcinoma or mesothelioma can be delineated. Furthermore, the properties a selected particulate that are important in the development of disease can be identified. For example, usage of different size preparations of a mineral, comparison of different mineral dusts, and pre-exposure of cells to selected inhibitors are approaches to reveal such properties. These studies aid in the development of markers which can be used in molecular epidemiological studies designed to identify individuals at risk for development of mineral dust-induced lung disease or detect early pulmonary responses to mineral dusts. Molecular biological techniques have become important tools in toxicological studies, in part due to the extreme sensitivity which enables studies on a small number of cells, and alternatively because these techniques allow analysis of genetic alterations triggered in individuals after exposure to toxins, including mineral dusts, and their relationship to disease formation or progres$\operatorname{sion}(9,10)$.

This thesis focused in part on alterations in antioxidants caused by mineral dust and presents $\mathrm{MnSOD}$ as a potential marker to identify pulmonary reactions to mineral dusts giving rise to inflammation, pulmonary damage and fibrosis. Studies to validate use of MnSOD in mineral dust-exposed individuals are being initiated. 


\section{REFERENCES}

1 Mossman BT, Bignon J, Com M, Seaton A, Gee JBL. Asbestos: Scientific developments and implications for public policy. Science 1990; 247:294-301.

2 Mossman BT, Marsh JP. Role of active oxygen species in asbestos-induced cytotoxicity, cell proliferation and carcinogenesis. In: Harris CC, Lechner JF, Brinkley BR (Eds.) Cellular and Molecular Aspects of Fiber Carcinogenesis. Cold Spring Harbor 1991 pp. 159-168.

3 Holley JA, Janssen YMW, Mossman BT, Taatjes D. Increased manganase superoxide dismutase protein in type II epithelial cells of rat lungs after inhalation of crocidolite asbestos ar cristobalite silica. Am J Pathol 1992; 141:475-485.

4 Marsh JP, Mossman BT. Mechanisms of induction of omithine decarboxylase activity in tracheal epithelial cells by asbestiform minerals. Cancer Res 1988; 48:709-714.

5 Marsh JP, Mossman BT. Role of asbestos and active oxygen species in activation and expression of ornithine decarboxylase in hamster tracheal epithellial cells. Cancer Res 1991; 51:167-173.

6 Petruska JM, Mossman BT, Brown RC, Hoskins JA. Mechanisms of action of minerla fibers as studied by in vitro methods. In: Liddell D, Miller K. Mineral Fibers and Health, CRC Press, Boca Raton, 1991 pp. 303-317.

7 Mossman BT. In vitro studies on the biological effects of fibers: Correlation with in vivo assays. Environ Health Perpect 1990; 88:319-322.

8 Mossman BT, Sesko AM. In vitro assays to predict the pathogenicity of mineral fibers. Toxicology 1990; 60:53-61.

9 Crapo JD, Miller FJ, Mossman B, Pryor WA, Kiley JP. Environmental lung diseases. NHLBI Workshop Summary. Am Rev Respir Dis 1992; 145:1506-1512.

10 Marshall E. Toxicology goes molecular. Science 1993; 259:1394-1398. 


\section{Samenvatting}

Blootstelling aan anorganisch stof op de werkplek kan leiden tot het ontstaan van een aantal longafwijkingen van maligne of niet maligne aard. Blootstelling aan asbestvezels kan fibrose (asbestose), mesothelioom, en longkanker (bronchogeen carcinoom) veroorzaken. Daamaast leidt blootstelling aan silicahoudend stof voornamelijk tot long fibrose (silicose). Het ontstaan van een longaandoening na expositie aan mineraal stof is afhankelijk van een aantal faktoren, onder andere, het type mineraal stof, de dosis die in de long achter blijft, en ook de individuele gevoeligheid. In de afgelopen jaren is gebleken dat zuurstofradicalen een belangrijke rol spelen in de pathogenese van longafwijkingen geinduceerd door mineraal stof. Dit proefschrift bestudeert de moleculaire respons geinduceerd door mineraal stof in rattelong en cel cultures. Hoofdstuk 2 beschrijft de moleculaire respons van cellen en weefsels na blootstelling aan zuurstofradicalen, of agentia die aanleiding geven tot vorming van zuurstofradicalen; hierbij is eveneens aandacht besteed aan vezels en partikels van minerale oorsprong om de respons die door stof geinduceerd worden te kunnen vergelijken met die geinduceerd door zuurstofradicalen. Hoofdstuk 3 belicht de rol van zuurstofradicalen in de toxiciteit van mineraal stof met meer diepgang. Sommige factoren die geinduceerd worden lijken uniek, afhankelijk de oxidatieve stress die gebruikt wordt. Andere eiwitten blijken juist vrij algemeen en worden in verschillende modellen van oxidatieve stress geinduceerd. Een voorbeeld hiervan is bijvoorbeeld het mangaan superoxide dismutase (MnSOD), een van de antioxidant enzymen. Bovendien hebben eiwitten die geinduceerd worden na oxidatieve stress geheel vershillende fucties. Sommige zijn antioxidanten, terwijl andere juist verband hebben met de differentiatie status van de cel, of zelfs met verhoogde proliferatie. Wat met name naar voren komt in de hoofdstukken 2 en 3 is dat ook eiwitten die geinduceerd worden door mineraal stof heel divers zijn. Hoewel antioxidanten geinduceerd worden, met een mogelijk beschermende werking, worden en tegelijkertijd proliferatieve effekten waargenomen die aanleiding kunnen geven tot longafwijkingen als fibrose, bronchogeen carcinoom en mesothelioom. Deze veranderingen in antioxidant enzymen, en daarnaast proliferatieve effekten vormen het kader van dit proefschrift (Hoofdstuk 1, figuur 2). 
Hoofdstukken 4 en 5 beschrijven de regulatie van antioxidant enzymen in rattelong na inhalatie van crocidoliet asbest, cristobaliet silica, of twee verschillende titaandioxides $\left(\mathrm{TiO}_{2}\right)$, waarvan één ultrafijn. Wat duidelijk naar voren komt uit deze studies is dat de verschillende mineralen aanleiding kunnen geven tot een verschillende mate van longbeschadiging of inflammatie en al dan niet leiden tot fibrose. Daarnaast worden componenten van het antioxidant enzymsysteem op verschillende wijze beinvloed. Inhalatie van crocidoliet asbest leidt bijvoorbeeld tot verhoogde genexpressie van de antioxidant enzymen, verhoogde eiwitniveaus van MnSOD en tot verhoogde antioxidant enzymactiviteiten in rattelong op verschillende tijdstippen na blootstelling. Cristobaliet silica laat een ander patroon zien: De genexpressie en eiwitniveaus van $\mathrm{MnSOD}$ in long zijn enorm verhoogd. Daarentegen was de expressie van de andere enzymen en ook enzymactiviteiten onveranderd. Een subchronische inhalatie studie met cristobaliet, bij tienvoudig lagere blootstellingsconcentraties gaf hetzelfde resultaat. De twee verschillende preparaten van $\mathrm{TiO}_{2}$ leverden geheel verschillende resultaten op. Ultrafijn $\mathrm{TiO}_{2}-\mathrm{D}$ veroorzaakte een acute long beschadiging, inflammatie, en leidde tot fibrose, terwijl $\mathrm{TiO}_{2}-\mathrm{F}$ geen inflanmatie veroorzaakte en de long nauwelijks aantastte. MnSOD genexpressie en eiwitniveaus waren significant verhoogd in longen van $\mathrm{TiO}_{2}-\mathrm{D}$ blootgestelde ratten terwijl $\mathrm{TiO}_{2}-\mathrm{F}$ inhalatie geen invloed had op MnSOD genexpressie of eiwitniveaus. Andere antioxidant enzymen bleven relatief onveranderd. Uit deze studies bleek dat MnSOD genexpressie direct correleerde met de inflammatie in de long (hoofdstuk 5).

Blootstelling van pleurale humane mesotheel cellen of humane long fibroblasten aan asbestvezels of zuurstofradicalen leidde eveneens tot veranderingen in antioxidant enzymen. Blootstelling van humane mesotheel cellen aan asbest of xanthine/xanthine oxidase (X/XO, een zuurstofradicalen genererend systeem) leidt tot verhoogde genexpressie van MnSOD. Daarnaast is genexpressie van het haemoxygenase, een enzym dat gevoelig is voor oxidatieve stress eveneens verhoogd. In humane longfibroblasten, een cell type minder gevoelig voor het cytotoxische effekt van asbest, werden na blootstelling van asbest of $\mathrm{X} / \mathrm{XO}$ geringere verhogingen in genexpressie van MnSOD of haemoxygenase waargenomen. Deze studie geeft aan dat een oxidatieve stress respons wel degelijk optreedt in de humane mesotheel cellen na blootstelling aan asbest of zuurstofradicalen (hoofdstuk 6).

Gelijktijdig met veranderingen in antioxidant enzymen werden er in rattelong en cel cultures, blootgesteld aan asbest ook proliferatieve veranderingen waargenomen. De moleculaire mechanismen verantwoordelijk voor de proliferatie veroorzaakt door minerale stoffen zijn nog onbekend. In het tweede gedeelte van dit proefschrift worden dan ook de moleculaire processen die geactiveerd worden in de cel door asbestvezels en het verband met chronische longafwijkingen bestudeerd. Hierbij is gebruik gemaakt van cultures van hamster tracheale 
epitheel cellen of rat pleurale mesotheel cellen. Asbest veroorzaakt een blijvende induktie van zowel c-fos als c-jun protooncogenexpressie in mesotheel cellen. DNA bindingsactiviteit van de AP-1 transcriptiefactor, opgebouwd uit jun/jun homodimeren of fos/jun heterodimeren, is eveneens verhoogd. Het crocidoliet asbest, de vezel die mesothelioom veroorzaakt, leidde tot een sterkere verhoging van c-fos en c-jun genexpressie vergeleken met het chrysotiel asbest. De negatieve controles riebeckiet, een deeltje chemisch identiek aan crocidoliet en polystyreen plastic veroorzaakten geen veranderingen in c-fos of $c$-jun. Andere "man made mineral fibers' induceerden genexpressie van c-fos en c-jun in geringere mate dan asbest. Studies met tracheale epitheelcellen tonen aan dat asbest c-jun genexpressie persistent induceert. De genexpressie van c-fos daarentegen blijft onveranderd in hamster tracheale epitheelcellen na asbestblootstelling. Ook in de tracheale epitheel cellen leidt asbestblootstelling tot verhoging in AP-1 DNA bindingsactiviteit. Dit betekent dat asbest de 'early gene response pathway' chronisch activeert hetgeen kan leiden tot de chronische longafwijkingen die geassocieerd zijn met asbestblootstelling (hoofdstukken 7 en 8).

De lange latentie periode van longziekten geinduceerd door mineraal stof maakt het noodzakelijk dat risico's die samenhangen met blootselling aan minerale stoffen vroegtijdig onderkend worden. Daarnaast is het wenselijk om longafwijkingen in blootgestelde individuen vroegtijdig op te sporen en die individuen die risico lopen op het onstaan van een longafwijking te identificeren. Door de responsen van cellen en/of weefsels na blootstelling aan minerale stoffen in kaart te brengen en het verband van deze responsen met chronische afwijkingen te bestuderen, kunnen markers geselecteerd worden die in moleculair epidemiologische studies gebruikt kunnen worden voor de hiergeschetste doelstelling. In dit proefschrift komt naar voren dat MnSOD zo'n marker zou kunnen zijn. MnSOD wordt geinduceerd in modellen van oxidatieve stress en na blootstelling aan minerale stoffen die in de rat leiden tot acute long beschadiging, inflammatie en fibrose. Momenteel worden er studies geinitieerd om genexpressie van MnSOD te meten in arbeiderspopulaties blootgesteld aan minerale stoffen, om gebruik van deze marker te valideren. 


\section{Publikaties}

\section{FULL PAPERS}

Janssen Y.M.W., Marsh J.P., Driscoll, K.E., Borm P.J.A., Oberdörster G. Mossman, B.: Increased expression of manganese-containing superoxide dismutase in rat lings after inhalation of inflammatory and fibrogenic minerals. Free Rad, Biol. Med. (In Press).

Heintz N.H., Janssen Y.M.W., Mossman B.T. Persistent induction of c-fos and c-jun expression by asbestos. Proc. Natl. Acad. Sci. USA. 90:3299-3303, 1993.

Janssen Y.M.W., Borm P.J.A., Van Houten B, Mossman B.T.: Cell and tissue responses to oxidative damage. Lab. Invest. (In Press).

Janssen Y.M.W., Marsh J.P., Absher M.P., Hemenway D., Vacek P.M., Leslie K.O., Borm P.J.A. and Mossman B.T.: Expression of antioxidant enzymes in rat lungs after inhalation of asbestos or silica. J. Biol. Chem. 267:10625, 1992.

Janssen Y.M.W., Engelen J.J., Giancola M.S., Low R.B., Vacek P. Borm P.J.A. Serum type III procollagen N-terminal peptide in coal miners. Exp. Lung Res. 19:1, 1992.

Holley J.A., Janssen Y.M.W., Mossman B.T., and Taatjes D.: Increased manganese superoxide dismutase protein in Type II epithelial cells of rat lungs after inhalation of crocidolite asbestos or cristobalite silica. Am. J. Path. 141:475, 1992.

Borm P.J.A., Schins R., Janssen Y.M.W., Lenaerts L. Molecular basis for differences in susceptibility to coal workers' pneumocononiosis. Toxicol. Letters 64/65:767, 1992.

Mossman, B.T., Janssen, Y.M., Marsh, J.P., Sesko, A., Shatos, M.A., Doherty, J., Adler, K.B., Hemenway, D., Mickey, R., Vacek, P., Petruska, J., and Kagan, E. Development and characterization of a rapid-onset rodent inhalation model of asbestosis for disease prevention. Toxicological Pathology 19:412, 1992.

Shull S, Heintz NH, Periasamy M, Manohar M, Janssen YMW, Marsh JP, and Mossman BT: Differential regulation of antioxidant enzymes in response to oxidants. J. Biol. Chem. 266:24398, 1991.

Sprong C.. Janssen Y.M.W., Borm P.J.A. The role of reactive oxygen species, cytokines and cytochrome P450 in pulmonary damage due to hyperoxia. Med. Hypotheses 34:286, 1991.

Janssen, Y., Marsh, J.P., Absher, M., Borm, P.J.A., and Mossman, B.T.: Increases in antioxidant enzymes during asbestos inhalation in rats. Free Radic. Res. Commun. 11:53, 1990.

Mossman, B.T., Janssen, Y.M.W., Marsh, J.P., Manohar, M., Garrone, M., and Shull, S.: Antioxidant defense mechanisms in asbestos-induced lung diseases. J. Aerosol Med. 3:75, 1990.

Kleinjans J.C., Janssen Y.M.W., van Agen B., Hageman G.J., Schreurs J.G. Genotoxicity of coal fly ash, assessed in vitro in Salmonella typhimurium and human lymphocytes, and in vivo in an occupationally exposed population. Mutat. Res. 224:127, 1989. 


\section{BOOKCHAPTERS}

Mossman, B.T., Quinlan, T.R., Janssen, Y.M.W.: Biological Effects of Environmental Agents Generating Active Oxygen Species on Cells and Tissues. In: Pathology of Human Environmental and Occupational Diseases (J.E. Craighead, ed.), Mosby Year Book, 1993.

Mossman, B.T., Marsh, J.P., Janssen, Y.M.W., and Heintz, N.H.: Mechanisms of asbestosmediated DNA replication and cell proliferation. In: Toxic and Carcinogenic Effects of Solid Particles on the Respiratory Tract, Proceedings of the 4th International Life Instituten Inhalation Symposium, ILSI Press, Washington DC, 1993 (In Press).

Driscoll, K.E., Maurer, J.K., Hassenbein, D., Carter, J., Janssen, Y.M.W., Mossman, B.T., Osier,M., and Oberdörster, G.: Contribution of macrophage-derived cytokines and cytokine networks to mineral dust-induced lung inflammation. In: Toxic and Carcinogenic Efects of Solic Particles on the Respiratory Tract, Proceedings of the 4th Intemational Life Sciences Institute Inhalation Symposium, ILSI Press, Washington DC, 1993 (In Press).

Driscoll, K.E., Strzelecki, J., Hassenbein, D., Janssen, Y.M.W., Marsh, J., Oberdorster, G., and Mossman, B.T.: Tumor necrosis factor (TNF): Evidence for the role of TNF in increased expression of manganese superoxide dismutase after inhalation of mineral dusts. In: Inhaled Particles VI, Ann. Occup. Hyg., Pergamon Press (In Press).

Janssen, Y.M.W., Borm, P.J.A., Marsh, J.P., and Mossman, B.T.: Role of oxidants in lung damage caused by fibers and particles. In: Oxidants in the Environment (J.O. Nriagu, ed.) John Wiley \& Sons, NY, (In Press) 1992.

Marsh, J.P., Janssen, Y.M.W., and Mossman, B.T.: Omithine decarboxylase and tumour proliferation: Role for oxidants. In: DNA and Free Radicals (B. Halliwell and O.I. Aruoma, eds.), Ellis Horwood, Ltd., New York, pp229-240, 1993.

Shull, S., Manohar, M., Marsh, J.P., Janssen, Y.M.W., and Mossman, B.T. Role of iron and reactive oxygen species in asbestos-induced lung injury, In: Free Radical Mechanisms of Tissue Injury, (M. T. Molsen and C. V. Smith eds.) CRC Press, Boca Raton, pp153-162, 1992.

Janssen Y.W.M., Marsh J.P., Borm P.J.A., Surinrut P., Haldeman K., and Mossman B.T.: Asbestos mediated gene expression in rat lung. In: Mechanisms in Fibre Carcinogenesis(R.C. Brown et al. eds) Plenum Press p359, 1991.

\section{ABSTRACTS}

Janssen, Y.M.W., Marsh, J.P., Borm, P.J.A., Heintz, N.H., Mossman, B.T. c-Fos and c-jun protooncogene expression in rat pleural mesothelial cells and hamster tracheal epithelial cells after exposure to asbestos and synthetic fibers. Am. Rev. Respir. Dis. 147(4):A910, 1993.

Janssen, Y.M.W., Held, P., Marsh, J.P., Borm, P.J.A., Heintz, N.H., and Mossman, B.T. Increased $c-f o s$ and $c-j u n$ gene expression and API DNA binding activity following exposure to crocidolite asbestos, TPA and active oxygen species Free. Rad. Res. Comms. vol 16 (1), 1992.

Janssen, Y.M.W., Marsh, J.P., Absher, M.P., Gabrielson, E. Borm, P.J.A., Mossman, B.T.: Gene expression of heme oxygenase and antioxidant enzymes in human mesothelial cells 
and human adult lung fibroblasts after exposure to asbestos or active oxygen species. Am. Rev. Resp. Dis. 145(4):A713, 1992.

Janssen, Y.M.W., Marsh, J., Driscoll, K., Oberdorster, G., Borm, P., and Mossman, B.T. Expression of antioxidant enzyme genes in rat lungs after inhalation of silica and titanium dioxide. Am. Rev. Respir. Dis. 143(4):A737, 1991.

Janssen, Y.M.W., Shull, S., Marsh, J.P., and Mossman, B.T. "Lung antioxidant enzymes in inhalation models of asbestosis and silicosis." Twenty-third International Congress on Occupational Health, Proceedings, Montreal, Canada, 1990.

Janssen, Y.M.W., Marsh, J.P., Shull, S., Borm, P.J.A., and Mossman, B.T. Profiles of antioxidant enzyme expression in rat lungs after inhalation of asbestos or silica. Meeting on Oxidative Damage \& Repair, Free Rad. Biol. \& Med. 9(Suppl 1):131, 1990.

Janssen Y., Marsh J., Absher M., Borm P., Mossman B. Lung antioxidants during the elaboration of asbestosis and silicosis in rats. Pharmaceutisch Weekblad Sci. Ed. 12:B7, 1990.

Mossman B., Shull S., Marsh J., Janssen Y. Mechanisms of asbestos-related injury. 'Particle -lung interactions:"Overload" related phenomena' organized by the International Society of Aerosols in Medicine (ISAM) and the Environmental Health Sciences Center (EHSC), Proceedings, Rochester NY, U.S.A. april 1990. 


\section{Curriculum Vitae}

Yvonne Janssen werd geboren op 24 mei 1966 to Elsloo. In 1984 behaalde zij het Atheneum-A diploma aan de Scholengemeenschap Groenewald te Stein.

Tussen 1984 en 1988 studeerde zij Gezondheidswetenschappen met als afstudeerrichting Biologische Gezondheidkunde aan de Rijksuniversiteit Limburg te Maastricht.

In 1989 trad zij als Assistent in Opleiding in dienst van de Rijksuniversiteit Limburg bij de Vakgroep Arbeidsgeneeskunde Milieugezondheidkunde en Toxicologie, en later bij Gezondheidsrisicoanalyse en Toxicologie. Een belangrijk gedeelte van het praktische onderzoek beschreven in dit proefschrift werd uitgevoerd in het laboratorium van Prof. Brooke Mossman, in het 'Department of Pathology, University of Vermont', te Burlington, VT, U.S.A. 


\section{Dankwoord / Acknowledgements}

Het onderzoek beschreven in dit proefschrift is tot stand gekomen in een samenwerkingsverband tussen de Rijkuniversiteit Limburg en 'the University of Vermont'. Co-promotor Paul Borm heeft dit geinitieerd en begeleidl vanuit Nederland op een fantastische wijze. Hij heeft zijn enthousiasme voor het vinden van biologische markers van belang in het veld van de longziekten aan mij overgedragen. Professor Pie Henderson, promotor, wil ik van harte bedanken voor de vele zinvolle discussies met betrekking tot toxicologie die altijd plaatsvonden wanneer ik in den lande aanwezig was.

Prof. Brooke Mossman has been a great teacher and the perfect example of a woman succesful in the mad world of science. She has been wonderful by inviting nne to work in her lab, supporting me and getting me excited about the use of molecular biological techniques in environmental diseases. I am indebted to Professor Nick Heintz, also at the University of Vernont, for his amazing help with the protooncogene research. Kevin Driscoll at Procter and Gamble has evaluated many manuscripts and made countless suggestions.

De mensen werkzaam bij Gezondheidsrisicoanalyse en Toxicologie wil ik bedanken voor de technische ondersteuning en interesse. Dankzij vele vrienden die nog steeds aanwezig zijn aan het thuisfront valt de overgang van de Amerikaanse naar de Nederlandse cultuur steeds weer mee. Ellen, Mieke, Hetty, Suzanne en Corinne, bedankt voor je vriendschap. Mijn ouders hebben me steeds opgevangen en ondersteund. Zij hebben mij aangezet tot studeren, waarvoor ik hen heel dankbaar ben. Jaqueueline, Fred, Susanne, Lollo, Sabrino en Meggie, m'n oma's en opa vormden steeds weer aanleiding om naar huis te komen.

Thanks to my coworkers, Joanne, who always has been much more than a mentor, Tim, Rebecca, and Ping, I was able to finish all the research that was presented here. Finally I would like to thank my buddies in Vermont, Lynne, Laurie, and Janet for the great introduction to the American way of life. My dear roommates, Julie, Pete, and Jo, always cheered me up during the hard times of writing this thesis. Cindy, Colleen, Angus, Kevin, Paul, Manos, Chris, Steve, and all the others who I didn't mention: thanks for the fun times. It's been a great four years. 


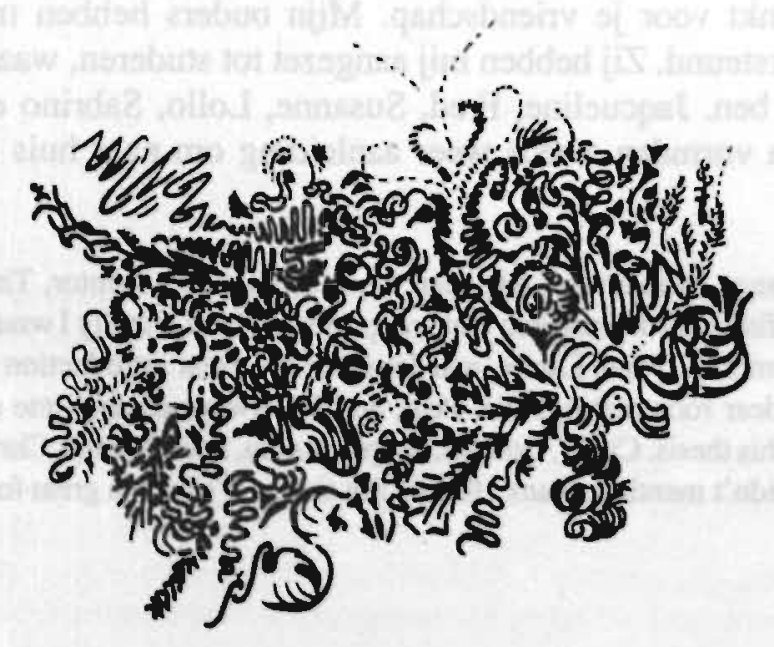



